\author{
Universidade de São Paulo \\ Instituto de Física \\ Instituto de Química \\ Instituto de Biociências \\ Faculdade de Educação
}

\title{
INTERDISCIPLINARIDADE: um conceito polissêmico
}

\author{
Valdir Pedro Berti
}

Orientadora: Prof ${ }^{\mathrm{a}}$. Dr ${ }^{\mathrm{a}}$. Carmen Fernandez

Dissertação de mestrado apresentada ao Instituto de Física, ao Instituto de Química, ao Instituto de Biociências e a Faculdade de Educação da Universidade de São Paulo, para a obtenção do título de Mestre em Ensino de Ciências.

Comissão Examinadora

Prof $^{a}$. Dr ${ }^{a}$. Carmen Fernandez (IQUSP)

Prof. Dr. Paulo Alves Porto (IQUSP)

Prof $^{a}$. Dr ${ }^{\mathrm{a}}$. Salete Linhares Queiroz (IQSCUSP)

São Paulo

2007 


\section{FICHA CATALOGRÁFICA}

Preparada pelo Serviço de Biblioteca e Informação do Instituto de Física da Universidade de São Paulo

Berti, Valdir Pedro

Interdisciplinaridade: um conceito polissêmico - São Paulo, 2007.

Dissertação (Mestrado) - Universidade de São Paulo. Instituto de Química

Orientadora: Profa. Dra. Carmen Fernandez Área de Concentração: Ensino de Ciências.

Modalidade Química

Unitermos: 1. Interdisciplinaridade; 2. Mapas Cognitivos; 3. Ensino.

USP/IF/SBI-069/2007 


\section{Dedicatória}

À Andréia, dedicatória justa àquela que admiro por ser parceira, mulher, mãe e fortaleza do refúgio da família.

E se não cumpri a promessa de deixar de estudar demasiadamente, princesa; tampouco deixei de amá-la com a mesma intensidade.

Definitivamente, não sou bom de promessas, porém sou fiel ao meu amor, com respeito, fidelidade e admiração. TE AMO SEMPRE! 


\section{In Memorian}

A você meu pai, cuja ausência tanta falta me faz. Confesso que a política, o futebol e a economia são assuntos que não trazem mais o "sabor" de uma gostosa conversa. Estou tentando me fazer educador, parte dessa formação busco encontrar na academia, a outra, no seu exemplo de vida.

E aos meus irmãos. Sérgio, cuja vida foi interrompida, levando a oportunidade de compartilhar seus valores para entendê-lo melhor. Carlos, presumo que a vida deveria ter lhe dado uma chance a julgar pelo excesso de trabalho.

À Profa. Dra. Reiko Isuyama, com quem tudo começou. 


\section{Agradecimentos}

A Deus pela oportunidade de estar vivo.

À minha orientadora Profa. Dra. Carmen Fernandez, que acreditou desde do início nesse trabalho e se fez presente e precisa em todos os momentos decisivos da pesquisa.

Aos meus filhos, Maria Beatriz, João Pedro e João Gabriel, a quem devo desculpas pela ausência, as quais não foram poucas. À minha mãe pela presença forte no incentivo ao estudo, sempre nos encorajando e derramando bênçãos.

À Regina, irmã zelosa. Sinto falta do convívio e dos diálogos, os quais sempre foram regados pela doçura de "mãe".

À dona Alaíde, minha sogra, que mesmo sem entender "pra que estudar tanto" contribuiu para que houvesse tempo para esse estudo. À Cida, nossa "Bá”, um anjo que Jeová colocou em nossas vidas, cuidando dos nossos filhos, com tanto amor.

Aos amigos Carlos e Eliana pela participação nas nossas vidas.

Aos amigos da Diretoria de Ensino de Tupã-SP, que acompanharam essa trajetória da pós-graduação. À Secretaria da Educação do Estado de São Paulo, pela Bolsa Mestrado, cujo afastamento remunerado permitiu realizar esse projeto de vida.

Ao nosso grupo PEQuim (Pesquisa em Ensino de Química) de cujo início participei.

A todos aqueles que de alguma forma, contribuíram para a realização desse trabalho.

Confesso que o tempo dedicado à Dissertação tem feito dela minha "rosa preferida", espero que ela consiga um lugar honroso nos jardins acadêmicos. 


\section{RESUMO}

Interdisciplinaridade é um termo que tem sido bastante utilizado no contexto educacional. A proposta deste trabalho é a de investigar os significados de interdisciplinaridade presentes na literatura e nos documentos oficiais educacionais brasileiros e compará-los com as concepções desse termo apresentadas por alguns professores. Para tanto, realizamos uma análise minuciosa da literatura e dos documentos oficiais (LDB, PCNEM, PCN+ e OCEM) buscando revelar as visões de interdisciplinaridade apresentadas. Na seqüência, realizamos entrevistas semi-estruturadas com dezesseis professores, oito dos quais atuantes no nível superior e pesquisadores na área de Ensino de Ciências (seis desses foram também consultores do MEC na elaboração dos documentos oficiais supracitados). Além desses, entrevistamos sete professores atuantes no Ensino Médio, três dos quais mestrandos em Ensino de Química. Das entrevistas foram selecionadas "unidades de análise" e mapas cognitivos foram construídos.

A partir das análises da literatura, dos documentos oficiais e dos mapas cognitivos, foi possível categorizar duas concepções de interdisciplinaridade que diferem epistemologicamente e metodologicamente: i.) a partir do professor; ii.) entre professores.

A concepção a partir do professor encontra eco nas proposições de Piaget, Jantasch, Bianchetti, Bertalanffy e nos documentos PCNEM e PCN+. Dos professores entrevistados, somente três estão de acordo com essa visão. Por outro lado, a defesa de uma proposta de interdisciplinaridade entre professores é defendida por Gusdorf, Japiassu, Santomé, Fazenda, Machado, Zabala e pelos documentos OCEM de 2004 e 2006. Essa também é a concepção da maioria dos professores entrevistados (treze de dezesseis).

Os dados apontam que a interdisciplinaridade convive com concepções diversas, revelando uma polissemia. Para os professores do Ensino Médio em exercício, entretanto, parece prevalecer a concepção de interdisciplinaridade entre professores. A proposta interdisciplinar num grupo de professores pode estar revelando, mais do que uma concepção epistemológica, uma necessidade de orientação sobre como efetuá-la na prática.

Palavras-chave: Interdisciplinaridade, Mapas Cognitivos, Concepções de professores. 


\begin{abstract}
Interdisciplinarity is a term that has been broadly used in educational context. The aim of this work is to investigate the interdisciplinarity conceptions that occur in the literature and in the Brazilian official documents and to compare such conceptions to teachers' understanding of this term. For this, we performed a thorough analysis of both the literature and the official documents (LDB, PCNEM, PCN+ and OCEM) in order to reveal the different views of interdisciplinarity. Next, we carried out semi-structured interviews with sixteen teachers; eight among them are University teachers and academic researchers in Science Education (six of these scholars had been consulting of the previously mentioned official documents). We also interviewed seven High School teachers, three of them enrolled in a Chemical Education graduate program. From the interviews, we selected "units of analysis" and assembled cognitive maps.

From the analysis of the literature, the official documents and the cognitive maps, two conceptions of interdisciplinarity that differ both epistemologically and methodologically were categorized: i.) within the teacher; and ii.) between teachers.

The conception within the teacher relates to the propositions of Piaget, Jantasch, Bianchetti, Bertalanffy and to the PCNEM and PCN+ documents. Among the interviewed teachers, only three share this view. On the other hand, the idea of interdisciplinary between teachers is expressed by Gusdorf, Japiassu, Santomé, Fazenda, Machado and Zabala and by the OCEM (2004 and 2006) documents. This conception is also encountered in most of the interviewed teachers (thirteen out of sixteen).

The data suggest that the interdisciplinarity concept coexists with very distinct interpretations, unveiling its polyssemic nature. For the in-service High School teachers, however, the conception of interdisciplinarity between teachers seems to prevail. The interdisciplinar approach in a group of teachers may be revealing, more than an epistemological conception, a need for orientation as regard to how to put it into practice.
\end{abstract}

Key Words: Interdisciplinary, Cognitive Maps, Teachers conceptions. 


\section{SUMÁRIO}

APRESENTAČ̃̃o

CAPÍTULO 1 - AS DISCIPLINAS 9

CAPÍTULO 2 -A INTERDISCIPLINARIDADE 21

CAPÍTULO 3 - A INTERDISCIPLINARIDADE NOS DOCUMENTOS OFICIAIS 28

3.1 A LDB E A INTERDISCIPLINARIDADE: O QUE A LEI APONTA PARA ESSA MODALIDADE DE ENSINO 29

3.2 OS PARÂMETROS CURRICULARES NACIONAIS E A INTERDISCIPLINARIDADE

3.3 NOVAS ORIENTAÇões PaRa O ENSINO MÉdIO: ORIENTAÇões EdUCACIONAIS COMPLEMENTARES-PCN+

3.4 ORIENTAÇões CURRICUlaRes PARA O ENSINO MÉdio (OCEM dE 2004 E 2006)

CAPÍTULO 4 - METODOLOGIA 47

4.1 PARTICIPANTES DA PESQUISA: NOSSO PÚBLICO 48

4.2 ANÁLISE DOS DADOS 51

CAPÍTULO 5 - RESULTADOS E DISCUSSÃO 56

5.1 RESULTADOS REFERENTES AOS PROFESSORES/PESOUISADORES 56

5.2 ANÁLISE DOS DADOS REFERENTES AOS ALUNOS DA PÓS-GRADUACÃO 76

5.3 ANÁLISE DOS DADOS REFERENTES AOS PROFESSORES DE EM DA DIRETORIA DE ENSINO DE TUPÃ

CAPÍTULO 6 - CONCLUSÕES 96

CONSIDERACÕES FINAIS 100

REFERÊNCIAS 102

APÊNDICE 1 106

APÊNDICE 2 107 


\section{Apresentação}

\section{Por que a Interdisciplinaridade?}

Meu contato com a interdisciplinaridade se deu no ano 2000, durante a participação em um grupo de pesquisa no ensino de química da Universidade de São Paulo, onde tínhamos a pretensão de trabalhar os conceitos de química, com atividades que buscavam aproximar os conceitos químicos às situações de vida dos alunos; na terminologia atual, uma contextualização. Algumas dessas propostas culminaram em tentativas de trabalho com projetos interdisciplinares. Cabe ressaltar, que o uso dessa terminologia interdisciplinar fazia pouco sentido, uma vez que o interesse desse grupo tinha um viés voltado a dar sentido ao ensino de química e não a questões de currículo integrado.

Nossos "projetos" consistiam de uma atitude em que, a partir de um tema, ou situação-problema começávamos a desenvolver uma pesquisa, e convidávamos os demais colegas a participarem dessa aventura. Foi assim com o projeto "Os Problemas Causados pelas Enchentes" nas comunidades que residiam próximas ao córrego Afonso Treze, no município de Tupã-SP, onde era despejado o esgoto da cidade sem o devido tratamento. Esse projeto foi realizado no ano de 2000, com os alunos dos segundos anos do CEFAM (Centro de Formação e Aperfeiçoamento ao Magistério), bem como, o projeto “Tabagismo" desenvolvido com os alunos da terceira série da EE Luís de Souza Leão, na cidade de Tupã-SP, no quarto bimestre de 2002.

Nesses trabalhos havia muito empenho e entusiasmo, porém pouca fundamentação teórica, pois como dissemos, não era o foco do grupo porpostas de currículo integrado.

No ano de 2003 fui convidado para ser Assistente Técnico Pedagógico (ATP) do Ensino Médio na Diretoria de Ensino-Região de Tupã-SP (D.E.). Na ocasião, trabalhei com um supervisor de ensino que tinha como proposta de trabalho os projetos interdisciplinares, tendo por fundamentação teórica a pedagogia de projetos de Fernando Hernandéz. Esse trabalho tinha como meta a implementação dessa proposta para todos os alunos da primeira série do ensino médio das escolas jurisdicionadas à nossa D.E. No ano seguinte, fariam parte os segundos e terceiros anos. No ano de 2004 participei do planejamento, elaboração e desenvolvimento de aulas de uma proposta de trabalho interdisciplinar, através de um caso de tratamento radioterápico, com a participação das disciplinas de Química, Física e 
Biologia; a qual culminou numa dissertação de mestrado pela UNESP de Bauru, intitulada: "Elaboração de uma Proposta Interdisciplinar para a Introdução da Física Moderna no Ensino Médio".

Nesse momento de mediação do trabalho com os professores das escolas, senti a necessidade de um maior embasamento teórico. Durante as leituras, reflexões e práticas, dúvidas começaram a fluir com a mesma intensidade dos desafios. Questões do tipo: quando a interdisciplinaridade se evidencia de maneira contundente na elaboração dos projetos? O que os professores pensam sobre essa prática?

Tais questionamentos, certamente, não poderiam ser respondidos no âmbito de uma Diretoria. Foi então, que resolvi eleger a interdisciplinaridade como objeto de pesquisa do meu trabalho de pós-graduação, e especificamente "a concepção de interdisciplinaridade" defendida por esses professores.

Para entender e posteriormente chegar a um posicionamento sobre alguns pontos essenciais que poderiam nortear e explicitar a identificação de uma prática interdisciplinar decidi, juntamente com minha orientadora, a professora doutora Carmen Fernandez, (re)visitar a literatura que trata de propostas de trabalho integradoras, em especial a interdisciplinaridade. Para tanto, escolhemos autores que tentavam diferenciar a interdisciplinaridade de outras propostas de trabalho integrado. Assim, necessariamente deparamo-nos com conceitos de disciplinaridade, bem como suas implicações nos diversos contextos ao longo da história do ensino. 


\section{Capítulo 1 - As disciplinas}

Pesquisar a questão de propostas integradoras (interdisciplinares) é sem dúvida um desafio, devido às diversas interpretações que o assunto suscita. De nossa parte, tentaremos entender o porquê essa modalidade de ensino ganhou forte expressão nas décadas de 70, 80 e 90, sendo recomendada nos documentos oficiais - Parâmetros Curriculares Nacionais (Brasil, 1999 e 2002). Objetivamos compreender, também, as concepções de interdisciplinaridade que têm sido propostas para o ensino. Imbuídos desse propósito, buscaremos conhecer um pouco mais sobre a interdisciplinaridade a partir dos fundamentos da disciplinaridade, pois julgamos que uma maior compreensão dos fundamentos disciplinares poderá contribuir para uma melhor elucidação da interdisciplinaridade. Para tanto, consideraremos alguns autores que pesquisam sobre a constituição de disciplinas no ensino, sem a preocupação estrita de uma suposta definição, devido à abrangência que o conceito abarca, sendo às vezes relacionado com princípios morais, matérias de ensino, ramo do conhecimento, conteúdos etc. Optamos por uma abordagem histórica, pois julgamos que a partir dos diversos contextos com realidades e necessidades específicas, possamos compreender as diversas "transformações" que a palavra disciplina sofreu ao longo da história.

Autores como Zabala (2002; 1998), Gusdorf (2006; 1984), Machado (2002; 2001), Santomé (1998), Japiassu (1976), Jantasch e Bianchetti (1995) entre outros, ao discutirem sobre a questão do ensino se remetem à Grécia Antiga e procuram fazer uma revisão histórica com o propósito de evidenciar suas mudanças. De maneira geral, eles consideram que os filósofos gregos cultivavam uma unidade do conhecimento, com um programa denominado Enkuklios Paidéia ${ }^{l}$, um ensino circular que levaria a percorrer o conhecimento

\footnotetext{
1 "Os gregos deixaram-nos igualmente a noção de enkuklios paidéia, que a nossa palavra enciclopédia transcreve e que, na sua significação etimológica quer dizer ensino circular. O círculo, forma perfeita, indica a necessidade de obrigar os alunos a fazer a volta completa dos conhecimentos disponíveis, reunidos na unidade de uma forma harmoniosa" (Gusdorf, 2006, p. 21). A palavra enciclopédia tem um sentido de curso acabado e perfeito. O pensamento racional grego é um modelo epistemológico que assegurava uma coerência global de um saber que, no conjunto, preservava a coerência harmoniosa do universo na sua universalidade (Japiassu, 1976). Ainda que não seja a pretensão dos autores considerados, cabe ressaltar, conforme Rochberg (1992), que os objetivos e métodos do conhecimento grego não são os mesmos dos atuais, pois seu contexto era
} 
constitutivo de ordem intelectual centrado no desenvolvimento humano, entendido como um todo. Platão, por exemplo, defendia uma educação para o enlevo da alma, baseada em núcleos organizadores de ginástica e música. Defendia, também, a necessidade de uma ciência unificada e propunha que essa tarefa fosse desempenhada pela filosofia. O Trivium (gramática, retórica e dialética), juntamente com o Quadrivium (aritmética, geografia, astronomia e música) eram programas de ensino integrado, que agrupavam os âmbitos do conhecimento denominados letras e ciências (Machado, 2002; Santomé, 1998).

Tradicionalmente na antiguidade, a Escola de Alexandria, centro de pesquisa e ensino de caráter neoplatônico, pode ser considerada a instituição mais antiga a assumir um compromisso com uma integração do conhecimento (aritmética, mecânica, gramática, medicina, geografia, música, astronomia, etc.) a partir de uma ótica filosófico-religiosa (embora também seja possível constatar muitos conflitos com o cristianismo). Lá concentravam-se sábios de todos os centros intelectuais do mundo helenístico; as influências judias, egípcias e gregas misturavam-se com outras mais distantes trazidas por mercadores e exploradores (Santomé, 1998, p. 46).

Já Aristóteles propunha uma divisão da ciência: física, matemática, filosofia e prática: lógica, ética e política. Essa tradição helenística de ensino enciclopédico foi mantida pelos filósofos romanos, como Quintiliano, que articulava o ensino em torno da gramática, música, geometria, astronomia, história e filosofia. Modelo semelhante de ensino era observado no século XIII, em que a universidade articulava gramática, retórica e dialética, com aritmética, geometria, astronomia e música, com o propósito de unificar as letras e as ciências (Zabala, 2002; Gusdorf, 2006; Machado, 2002; Santomé, 1998). Entretanto, nos séculos XVII e XVIII essa forma de unidade do pensamento começou a sofrer mudanças, as quais são apontadas pelos autores considerados, com algumas particularidades.

Santomé (1998) considera que o processo de transformação social ocorrido nos países europeus desenvolvidos necessitava de uma especialização de acordo com a divisão material do processo de produção favorecido pela industrialização. Neste contexto, as técnicas e saberes foram se diferenciando progressivamente e, por sua vez, as linguagens que os caracterizavam foram se especializando e circunscrevendo âmbitos específicos.

formado de realidades e valores diferentes, o que impossibilita trazer essa noção de ensino em épocas diferentes. 
Deste modo, surgiu o conceito de disciplina como um objeto de estudo, marcos conceituais, métodos e procedimentos específicos. "Uma disciplina é uma maneira de organizar e delimitar um território de trabalho, de concentrar a pesquisa e as experiências dentro de um determinado ângulo de visão. Daí cada disciplina nos oferecer uma imagem particular da realidade, isto é, daquela parte que entra no ângulo de seu objetivo" (Santomé, 1998, p. 55). A divisão disciplinar com estruturação de diversas disciplinas passou a estudar de forma organizada e sistemática as diferentes classes de fenômenos do universo, da matéria, da vida humana e dos seres vivos. E, de acordo com as necessidades, iam-se formando os especialistas em cada uma das disciplinas, numa concepção funcionalista do currículo baseada, segundo Santomé, no método cartesiano ${ }^{2}$.

Para Zabala (2002), essa unidade do conhecimento teve considerável interrupção no século XIX, quando:

\begin{abstract}
Napoleão, em 1808, organiza o sistema de ensino na França criando a universidade de letras e as faculdades de ciências. Essa concepção estende-se a todo mundo ocidental, formando assim, uma diversificação intelectual ao criar a necessidade entre os alunos de escolher entre uma cultura literária e a cultura científica, já que cada uma dessas culturas é separada da outra. Tal compartimentação do saber provocou o seguinte: um setor considerável do campo epistemológico é construído como se o outro não existisse (Zabala, 2002, p. 18).
\end{abstract}

Essa divisão formativa fragmentou-se em âmbitos humanísticos e científicotecnológicos, que, posteriormente fomentados por interesses de especialistas disciplinares, levou a um aumento crescente das disciplinas. Como resultado, a seleção e organização dos conteúdos de aprendizagem foram sendo formados sob critérios de importância

${ }^{2}$ Referente a René Descartes (1596-1650), que na sua obra "Discurso do Método" propõe sintetizar o uso da dúvida para formalização de um método eficaz. Para tanto, sugere que devamos dividir o que se pretende conhecer até não haver mais dúvidas sobre tal coisa. O método de raciocínio proposto pelo filósofo defende que podemos encontrar as verdades distintas e claras. Em seu tratado filosófico enuncia as etapas para encontrar as verdades absolutas. Basicamente, os passos ou preceitos são os seguintes:

I- Receber escrupulosamente as informações, examinando sua racionalidade e justificação. Verificar a boa procedência daquilo que se investiga e aceitar o que seja indubitável, apenas. Ser o mais cético possível, antes de aceitar algo como verdadeiro.

II- $\quad$ Analisar, ou seja, dividir o assunto em tantas partes, quanto possível e necessário.

III- Sintetizar de forma progressiva e ordenada as conclusões, a partir de objetos mais simples e fáceis, até os mais difíceis.

IV- $\quad$ Enumerar e revisar minuciosamente as conclusões de tal forma que nada seja omitido, garantindo a coerência.

Estas etapas, garante o filósofo, constituem três operações elementares da mente humana: a indução, a dedução e a enumeração. E que aplicadas corretamente permitem chegar à verdade (Descartes, 2005; Padovani e Castagnola, 1967). Para Descartes, esses são os caminhos mais seguros para se chegar à ciência. 
estritamente disciplinares, os quais estavam vinculados ao poder e pressão de diferentes grupos profissionais que determinavam a permanência ou não de algumas disciplinas.

Gusdorf (2006) considera que o processo de especialização disciplinar foi marcadamente iniciado nos séculos XVII e XVIII, com forte expressão no século XIX, tornando-se a partir daí regra absoluta na busca do conhecer. Neste contexto, segundo Gusdorf, os ideais positivistas $^{3}$ tornaram-se uma atitude em que se buscava conhecer os fatos, excluindo as referências de valores. Tudo se passava como se só fosse possível conhecer a partir de recortes sobre o objeto de estudo. Essa epistemologia da fragmentação se verificava no domínio da química, com a divisão em química mineral e orgânica; na física, com o domínio de partes dessa ciência e na medicina com a formação de especialistas. As universidades perderam o sentido de universalidade, tornando-se "células" isoladas em compartimentos estanques, cuja preocupação maior era a de defender os seus pequenos domínios. Piaget (1978) também assevera que esses desmembramentos disciplinares se explicam nos conceitos positivistas, em que se consideram os fenômenos observáveis e, basicamente seria necessário descrever e analisar para se extrair as leis funcionais. Inevitavelmente, tal epistemologia traz como conseqüência a separação em disciplinas. Ecos desse pensamento podem ser encontrados em Machado (2002; 2001) e Japiassu (1976), ao se referirem que a organização disciplinar é resultante de uma epistemologia que acaba por determinar sua forma, entendendo que o positivismo e o pensamento cartesiano apresentam nas suas bases a concepção de que as ciências devem dispor-se conforme uma ordem de subordinação hierárquica, para formar uma cadeia

${ }^{3} \mathrm{O}$ positivismo é um movimento que procura enfatizar a necessidade de se considerar a experiência e os dados positivos. Ele se caracteriza por uma interpretação da experiência, mediante a razão; daí seu maior valor como descrição e análise objetiva da experiência. Dessa objetividade entende-se a sua fecundidade no campo prático, técnico e aplicado, resultando no progresso das ciências naturais no século XIX. O positivismo admite como fonte de verdade, a ciência, os fatos positivos e dados sensíveis e desconsidera qualquer interpretação e justificação que transcenda a experiência. Concebe a evolução por causas, através de um conflito mecânico de seres e forças, na luta pela sobrevivência. Para o positivismo, a única realidade existente e cognoscível é a realidade física, a qual só pode ser atingida cientificamente (Padovani e Castagnola, 1967). Uma das maiores expressões do positivismo foi o francês Auguste Comte (1798-1857) que sustentava que as idéias da civilização, no geral, se caracterizavam por três etapas de pensamento:

- A fase teológica, em que a humanidade recorre a seres transcendentes e divinos para explicar os fenômenos da experiência;

- A metafísica, onde se recorre a entidades racionais abstratas;

- E por fim, a positivista, em que se pretende entender os fatos unicamente em sua realidade empírica, e em suas relações científicas (Padovani e Castagnola, 1967, p. 432). 
orientada de conhecimento, sem dependências recíprocas. Uma estruturação, portanto, que tende ao isolamento.

Jantsch e Bianchetti (1995) trazem uma reflexão sobre o processo histórico do conhecimento, atribuindo alternâncias entre unidade e fragmentação do conhecimento em decorrência do contexto. Afirmam que atualmente o movimento se descola no sentido da globalização, o que pode ser observado pelo movimento de unificação da Alemanha, na Comunidade Econômica Européia, no Mercosul etc. Contudo, destacam que os ventos históricos sopram em direções alternadas, pensamento partilhado por Santomé (1998). Em meio às mudanças de ares entre ensino integrado e disciplinar, é no pensamento grego que esses autores reconhecem a unidade do conhecimento motivada pela organização e estruturação da sociedade:

\footnotetext{
O objeto epistemológico simplesmente era o conhecimento, que podia se desdobrar em subdivisões, sem que evocasse a fragmentação ou a necessidade de totalização ou retotalização desse conhecimento. Predominava a idéia de unidade, herança da primeira escola filosófica cosmológica (Jantsch e Bianchetti, 1995, p. 184).
}

Ainda segundo Jantsch e Bianchetti (1995), a partir de Aristóteles ${ }^{4}$, percebe-se uma produção voltada às "especialidades", embora destaquem que o filósofo não tivesse essa pretensão. Na Idade Média procurava-se manter a idéia de unidade, sustentadas por dogmas e meios coercitivos. Este modelo foi sucedido pela burguesia, que trazia nas suas bases mercantilistas as especialidades, processo de produção do conhecimento iniciado pelo filósofo Aristóteles. Dessa forma, Jantasch e Bianchetti procuram mostrar que esse processo, longe de ser linear, se deu de forma alternada.

Em que se pese algumas particularidades, notamos que fundamentalmente os autores considerados atribuem ao positivismo e às idéias do filósofo René Descartes uma parcela significativa pela disciplinarização do conhecimento e por decorrência, a criação de especialistas. Tais atributos, certamente são provenientes da forte influência desses pensamentos no campo do conhecimento. Se as conjunturas econômica e social da época necessitavam de formação especializada para atender suas necessidades, ao que parece, as universidades incorporaram o modelo de especialização, tendo por base princípios cartesianos e positivistas.

\footnotetext{
${ }^{4}$ Zabala (2002), também atribui essa divisão ao filósofo.
} 
Autores como Lopes, Chervel, Goodson e Juliá, entretanto, têm um olhar basicamente voltado para o século XIX.

Para Lopes (2007, 2002), a dimensão disciplinar do currículo tem duas vertentes: uma associada aos que defendem a organização do conhecimento escolar em uma sequiência de conteúdos selecionados em vários campos do saber a partir de uma lógica disciplinar, em que cabe às escolas, apenas a função de simplificar o conhecimento e transmití-los; e outra associada aos que enfatizam se tratar de uma reconstrução e ressignificação dos saberes, cabendo à escola a produção desses saberes. De comum às duas, Lopes considera que ao longo da história tem prevalecido a prática do currículo disciplinar, pois: "a despeito de todas as tentativas de organização de um currículo nãodisciplinar é por intermédio das disciplinas que o conhecimento vem sendo prioritariamente transmitido às escolas" (Lopes e Macedo, 2002, pp. 73-74). Assim, a disciplinarização não é uma questão de conjuntura, pois ela existe historicamente. No seu entender, o currículo disciplinar está ligado às relações sociais e essas se traduzem nas formas de organização da sociedade e controle dos espaços institucionais. Sua legitimação é sustentada por valores sociais como diplomas, concursos, categorias, etc. Em virtude disso, o currículo disciplinar existe, porque atende às exigências sociais, as quais se traduzem em uma hierarquização das pessoas, dos saberes, dos interesses das corporações. A disciplinaridade prevalece porque responde satisfatoriamente a essas necessidades. Lopes admite, também que essa concepção de disciplina sócio-histórica de organização curricular leva à fragmentação do conhecimento (Lopes e Macedo, 2002). E que uma vez constituída tende a permanecer, pois, segundo Veiga-Neto (1998) quando se tenta fundir duas ou mais disciplinas, ocorre que elas não se fundem ou apenas partes delas se fundem.

De acordo com Lopes (2007; 2002) existem dois tipos de currículo: escolar e acadêmico, ainda que freqüentemente ambos são analisados como disciplinas acadêmicas. As disciplinas escolares são frutos de uma seleção cultural condicionada por fatores sócioculturais, políticos e econômicos, os quais, segundo Lopes, estão além de critérios essencialmente epistemológicos, que são marcantes nos currículos acadêmicos. Chervel considera que esse equívoco de atribuir o mesmo significado aos dois tipos de currículo vem se modificando: "Estima-se ordinariamente, de fato, que os conteúdos de ensino são impostos como tais à escola pela sociedade que a rodeia e pela cultura na qual ela se banha" 
(Chervel, 1994, p. 180). Ele busca na história da gramática escolar, por exemplo, evidências que esses saberes têm origem e propósitos diferentes:

\begin{abstract}
- a teoria da gramática ensinada na escola não é a expressão das ciências ditas, ou presumidas de referência, mas que ela foi historicamente criada pela própria escola, na escola e para a escola;

- o conhecimento da gramática escolar não faz parte da cultura do homem cultivado;

- a gênese dessa gramática escolar não deixa dúvidas sobre a sua finalidade, ou seja, a criação de seus diferentes conceitos tem constantemente coincidido no tempo com o seu ensino (Chervel, 1994, pp. 181-182).
\end{abstract}

Ao defender essa natureza histórica e social das disciplinas escolares, Lopes dialoga também com Goodson (1997) que concebe o currículo como uma construção com dimensões sociais, procurando compreender a estrutura na qual ele está inserido, formulado por pessoas e para pessoas, o que dá uma dimensão humana ao fazer escolar em todas as suas instâncias. Um currículo que é construído de fora para dentro e de acordo com Layton, está vinculado a três estágios de evolução:

\footnotetext{
- no primeiro estágio, em que a disciplina é introduzida no currículo escolar tendo por argumentos justificáveis a pertinência e a utilidade.

- no segundo, começa estabelecer uma certa tradição acadêmica para a disciplina e inicia-se o processo de formação de especialistas que passam a atuar como professores.

- finalmente, em que a disciplina já se encontra estabilizada, contando com um corpo de professores treinados e um conjunto de regras e valores estabelecidos. Etapa conhecida como o prelúdio do desencantamento, em que a adesão do aluno à disciplina passa a se manter apenas por questão do status acadêmico.

(Layton, apud Lopes e Macedo, 2002, p. 79).
}

Ainda que de maneira não tão linear, Goodson (1997) corrobora esse pensamento, ao apontar que na história da disciplina escolar tem-se observado o movimento de passagem de uma abordagem mais pedagógica e utilitária para uma tradição mais acadêmica. $\mathrm{O}$ que nos permite deduzir que a disciplina escolar não é uma transposição didática das disciplinas acadêmicas. Ao contrário, ela é uma construção histórica, social, cultural e política, legitimada por embates e em constante transformação.

Para Chervel (1994) e Juliá (2002), a história do ensino tem uma tradição secular, entretanto, isso não ocorre no ensino primário e secundário. Segundo os autores, os interesses nessas modalidades de ensino são marcadamente pontuais e só recentemente iniciou-se um movimento dos docentes com interesses da sua própria disciplina, 
possibilitando uma visão mais abrangente do problema. De acordo com Chervel, a palavra disciplina escolar aparece no século XIX, com o significado de vigilância dos estabelecimentos e repressão de condutas prejudiciais à sua boa ordem. $\mathrm{O}$ verbo disciplinar neste contexto propunha "disciplinar a inteligência", em que a matéria de ensino, no caso a disciplina literária, servia de exercício intelectual para educar a inteligência. "Disciplinar a inteligência das crianças, isto constitui o objeto de uma ciência especial que se chama pedagogia" (Chervel, 1994, p. 179).

Posteriormente, o conceito sofreu mudanças motivadas por interesses sociais, quando se fez sentir a necessidade de uma definição entre ensino literário e de ciências. Outra mudança ocorreu após a Primeira Guerra Mundial, em que o termo disciplina perdeu o significado de "formação do espírito" para tornar-se uma simples designação de "matérias de ensino". Para Chervel (1994), Juliá (2002) e Lopes e Macedo (2002), entretanto, esse enfraquecimento de sentido disciplinador, só ocorreu na linguagem, pois na prática ele continua desfrutando de uma forte estrutura e organização, não tendo interrompido seu sentido histórico:

Uma 'disciplina', é igualmente, para nós, em qualquer campo que se encontre um modo de disciplinar o espírito, quer dizer de lhe dar os métodos e as regras para abordar os diferentes domínios do pensamento, do conhecimento e da arte (Chervel, 1994, p. 180).

Nos espaços escolares essa noção de disciplina pode ser observada na formação das matrizes disciplinares, nos horários de seus funcionamentos, que acabam controlando os agentes que participam dessas instituições.

De forma geral, os autores considerados evidenciam uma diferenciação entre ensino integrado e disciplinar que se firmou acentuadamente a partir do século XIX. Lopes, Chervel, Goodson e Juliá, além disso, diferenciam as disciplinas em acadêmicas e de ensino, considerando que as disciplinas de ensino estão muito ligadas a valores sociais e culturais. Segundo esses autores, relações de poder e predominância acabam por determinar os seus isolamentos a âmbitos específicos, o que torna as disciplinas mais e mais isoladas. Heckhausen (2006), em seu trabalho "Disciplina e Interdisciplinaridade" reforça fortemente este isolamento, relacionando sete critérios para se distinguir uma disciplina de outra: 
1- domínio material que corresponde ao objeto de estudo da disciplina;

2- domínio de estudo das disciplinas, o qual determina o conjunto possível dos objetos observáveis;

3- nível de integração teórica das disciplinas, que corresponde ao domínio em termos teóricos, como a capacidade de prever os fenômenos e acontecimentos;

4- métodos das disciplinas, em que as disciplinas elaboram seus métodos específicos;

5- instrumentos de análise das disciplinas, os quais se apóiam em estratégias lógicas, raciocínios matemáticos e na construção de modelos;

6- aplicações práticas, as disciplinas diferem entre si quanto à possibilidade de aplicação e de utilização prática no campo da atividade profissional;

7- contingências históricas das disciplinas, que aceleram a evolução de algumas disciplinas e a estagnação de outras. Elas são submetidas a forças externas em constante evolução, tais como prestígio da opinião pública, os valores sócioculturais, as ideologias políticas e condições econômicas (Pombo, 2006; Heckhausen, 2006).

Gusdorf (2006; 1984) considera que essa divisão foi incentivada por muitos fatores, porém coloca-os num viés de interesses pessoais ao se referir que o isolamento das disciplinas facilita o desenvolvimento do trabalho intelectual e julga ser esse o motivo pelo qual os especialistas conservam suas parcelas de domínio disciplinar:

\footnotetext{
- Obstáculo epistemológico: cada disciplina uma vez emancipada do conhecimento pleno subdivide-se por sua vez em setores autônomos.

- Obstáculo institucional: cada disciplina ocupa a sua casa, consagrando por uma via administrativa a sua separação, de corpo e de bens, relativamente ao saber no seu conjunto. A inspiração imobiliza-se nas instalações; centrada sobre si mesma, tendendo a cortar as comunicações com o resto do espaço mental e esforça-se por consolidar a qualquer preço a situação adquirida.

- Obstáculo cultural: a separação entre as disciplinas agrava-se igualmente com a separação entre as áreas culturais e as mentalidades particulares, entre as línguas e as tradições. A "ciência" tal como é atualmente é fenômeno tipicamente ocidental, sua invenção não vai além do século XVII. Não há dúvidas que a ciência ocidental se impôs ao resto do universo graças à eficácia determinante das suas aplicações técnicas. Porém, os sábios de um país trabalham em circuito fechado, sem se preocupar demasiado com o que se passa alhures (Gusdorf, 2006, pp. 47-52).
}

Ideologias à parte, talvez a questão pertinente que se coloca é o que motiva as disciplinas plenamente reconhecidas e consolidadas tentarem um diálogo cooperativo com as demais?

Na obra "Para onde vai a educação?", Piaget, ao comentar o desinteresse dos alunos nos cursos de iniciação científica, esclarece que o problema parece estar mais centrado nos métodos adotados no Ensino de Ciências, do que na capacidade de aprendizagem dos alunos: 
Parece, pois fora de dúvida que, para reajustar, nesse particular, as formações escolares às exigências da sociedade, será preciso proceder a uma revisão dos métodos e do espírito de todo o ensino, muito mais do que contentar-se em apelar para simples fatores de bom-senso (Piaget, 1978, p. 13).

Um problema que envolve não apenas a didática de cada disciplina ligada ao Ensino de Ciências, mas a questões mais abrangentes, como a significação real dos métodos ativos, utilização dos conhecimentos psicológicos adquiridos acerca do desenvolvimento da criança e do adolescente e do caráter de integração das disciplinas necessário em todos os níveis, em oposição ao fracionamento presente nas universidades e nos ensinos primários e secundários. Para Piaget, os fracassos escolares constatados se devem a passagens muito rápidas do qualitativo (lógico) para o quantitativo (numérico), em que se cumpre basicamente memorizar conceitos e fórmulas (algoritmos). Isso decorre de uma formação deficitária dos educadores, tornando-os mal preparados em virtude de uma formação que visa a especialização, resultando por decorrência na fragmentação das disciplinas com pouco significado para os alunos (Piaget, 2006; 1978). Se Piaget coloca o diálogo das disciplinas como uma necessidade de uma aprendizagem de natureza epistemológica, Gusdorf, por sua vez, coloca-a num âmbito filosófico, ao se referir que as ciências humanas encontram-se inegavelmente caracterizadas por um estado de desmembramento, motivado por um movimento histórico que tem por base o modelo de especialização das áreas. Segundo ele, as disciplinas se desenvolveram e se subdividiram quase que a um número ilimitado de subdisciplinas chegando a ponto de não ser possível o domínio de um grupo de disciplinas por um único especialista. Para Gusdorf é inegável considerar que todas as formas pelas quais o conhecimento histórico se consolidou teve como propósito o próprio homem. Portanto, a unificação do conhecimento é uma exigência necessária à unificação do mundo. Mais do que isso, é a possibilidade de reconciliação do homem com ele próprio. Assim, as disciplinas possuidoras desse saber sistematizado, funcionam como catalisadores na consecução desses ideais. A raiz do problema não parece estar na existência das disciplinas mas, na dimensão excessiva do seu valor, levando ao isolamento das disciplinas e do homem. Para Gusdorf, trabalhar na convergência das disciplinas na busca da unidade humana deve ser o propósito do conhecimento, pois a unidade é antes de tudo um estado de espírito, que antecede toda e qualquer pesquisa (Gusdorf, 2006; 1984). 
Japiassu (1976) menciona que a superação do excesso de departamentalização do saber exige que cada participante esteja impregnado de um fundamento epistemológico suficientemente amplo capaz de observar as relações da sua disciplina com as demais, sem negligenciar o terreno de sua especificidade. Para ele, atualmente, há esforços que apontam para um movimento de integração das disciplinas, motivados pela exigência da pesquisa científica, que dispõem de equipamentos de alta complexidade de difícil domínio de um único especialista.

Bertalanffy (1977), de comum acordo, menciona que a evolução tecnológica deixou de trabalhar com máquinas isoladas para atuar com sistemas complexos, sendo impossível conceber que um único especialista de qualquer área do conhecimento possa desempenhar tal empreendimento isoladamente: "de uma maneira ou de outra, somos forçados a tratar com complexos, com 'totalidades' ou 'sistemas" em todos os campos do conhecimento" (Bertalanffy, 1977, p. 19).

Para Morin $(2002 ; 2001 ; 2000 ; 1995)$, a problemática da complexidade tem sido marginal no pensamento científico, epistemológico e filosófico. No tocante às interações disciplinares, há dois pontos no pensamento complexo que julgamos pertinentes considerar. O primeiro refere-se ao fato de, no pensamento complexo, o movimento ocorrer do todo para as partes e simultaneamente das partes para o todo, produzindo um conhecimento de complexidade superior. O segundo, é que o pensamento complexo não tem a pretensão de conhecer a totalidade universal; o universal neste pensamento são as noções de sistemas, que no pensamento de Morin, são as únicas entidades dotadas de realidade, sentido e significado:

(...) o Sol é um sistema, a Terra é um sistema, a biosfera é um sistema etc. etc. mesmo uma bactéria é um sistema, a cadeira é um sistema, o automóvel é um sistema; são constituições a partir de elementos. Não somente tudo é sistema, mas me parece, que curiosamente para nós, somente o sistema é real. Desde que você tome uma partícula isolada, você não mais sabe mais se ela tem uma realidade e qual é o tipo de realidade. Quando começa a se constituir o sistema que é o átomo, você diz: 'Ah, isto tem uma certa realidade'; mas desde que você é infra-sistêmico, é como se não existisse mais realidade (Morin, 1995, p. 86).

\footnotetext{
${ }^{5}$ De acordo com Bertalanffy, a definição geral de sistema corresponde a "um certo número de elementos em interação" (1977, p. 119).
} 
Morin busca superar as concepções dos pensamentos cartesianos e positivistas, que propõem dividir para entender. A epistemologia da complexidade propõe conhecer, a partir das complexificações do objeto, pensando-o como todo/partes. Na biologia, Maturana procura explicitar a epistemologia da complexidade na própria manifestação da vida, como uma rede de processos, na qual cada elemento constitutivo participa da produção de si e dos outros. A rede produz os componentes e é produzida pelos seus componentes. Uma autopoieses em permanente interação como o meio (Maturana, 2002; Maturana e Varela, 2001).

Essa complexidade pode ser verificada também no pensamento de Zabala (2002; 1998) quando se refere às finalidades educativas do conhecimento no processo do ensino: “(...) podemos chegar à conclusão de que a organização dos conteúdos deve permitir o estudo de uma realidade que sempre é complexa e em cuja aprendizagem é preciso estabelecer o máximo de relações possíveis entre os diferentes conteúdos que são aprendidos para potencializar a sua capacidade explicativa" (Zabala, 2002, p. 35). As disciplinas no ensino são instrumentos que adquirem seus verdadeiros significados quando nos permitem, de forma relacionada, dar repostas aos problemas complexos que o cotidiano nos coloca, uma complexidade que é própria do objeto do contexto. E, conforme Zabala, se considerarmos que a finalidade da educação é entender o que se estuda para saber aplicar às situações diversas, é necessário o diálogo das disciplinas com o máximo de relações possíveis para melhor compreender o objeto considerado.

As disciplinas podem estabelecer um diálogo, sem que haja a predominância de uma sobre a outra, nem tampouco a sua extinção. Uma proposta capaz de supostamente fazer interagir saberes na obtenção de conhecimento novo e de natureza superior. Uma proposta que atende sob o nome de interdisciplinaridade. 


\section{Capítulo 2 -A Interdisciplinaridade}

Neste capítulo trataremos de propostas integradas, mais especificamente a interdisciplinaridade, buscando alguns autores que tratam do assunto, como: Jean Piaget, Antoni Zabala, Georges Gusdorf, Hilton Japiassu, Jurjo Torres Santomé, Ivani Fazenda, Ari Paulo Jantasch e outros. Nosso objetivo é o de entender as concepções de interdisciplinaridade, bem como, a forma de se trabalhar essa proposta de ensino. Confiantes de que a teoria ilumina a prática, buscamos (re)visitar a literatura com o propósito de contribuir, de alguma forma, para o esclarecimento de práticas interdisciplinares. Abordaremos os conceitos defendidos pelos autores, porém não temos a pretensão de unificá-los, pois acreditamos se tratar de um termo que evoca mais de um significado. Nosso enfoque literário se concentrará entre as décadas de 70, 80, 90 até o momento atual, pois julgamos que nesses períodos a interdisciplinaridade teve forte expressão na pesquisa e no ensino. A seleção dos autores brasileiros se deu pela notoriedade no assunto e os demais foram se constituindo a partir das referências desses autores e dos documentos oficiais.

Piaget (1978) defende que a aproximação das disciplinas está relacionada ao aspecto epistemológico, pois algumas delas têm formas muito próximas de atuar na consecução do conhecimento, como por exemplo, na Física e na Química, na Biologia e Físico-Química. No conceito piagetiano de estruturalismo, os esquemas de ação ${ }^{6}$ permitem dar significado ao objeto, que ao assimilá-lo, vai se diferenciando através de acomodações. Os esquemas referem-se àquilo que, numa ação, é transponível, generalizável ou diferençável de uma situação à seguinte, ou seja, o que há de comum nas diversas repetições, ou aplicações da mesma ação. O estruturalismo resulta da reorganização dos esquemas e serve de base para a construção de nova estrutura em nível mais elevado, que vai se desenvolvendo em quantidade e qualidade (Moreira, 1990). Essa teoria é uma das concepções decisivas na consolidação do momento de interação (interdisciplinar), pois evidencia estruturas comuns

\footnotetext{
${ }^{6}$ Segundo Wadsworth (1996), Piaget considera que a mente seria dotada de estruturas do mesmo modo que o corpo. Os esquemas (schemata) são estruturas mentais ou cognitivas pelas quais os indivíduos intelectualmente organizam o meio. Esses esquemas se modificariam com o desenvolvimento mental, tornando-se cada vez mais refinados à medida que a criança torna-se mais apta a generalizar os estímulos.
} 
às disciplinas. Dessa forma, “(...) não temos mais que dividir a realidade em compartimentos impermeáveis, ou plataformas superpostas correspondentes às fronteiras aparentes de nossas disciplinas científicas; pelo contrário vemo-nos compelidos a buscar interações e mecanismos comuns" (Piaget, 1979 apud Santomé, 1998, p. 50). O estruturalismo refere-se à possibilidade de se conhecer mais de outras disciplinas; em que cada qual possa generalizar as estruturas e redistribuí-las nos sistemas de conjunto que englobam outras disciplinas: “(...) uma ampliação sistêmica dos pontos de vista, nada impedindo que os professores de línguas adquiram uma cultura lingüística suficiente para conferir um espírito mais arejado da gramática, (...)” (Piaget, 1978, p. 24).

De acordo com Piaget, no momento em que se procura entender os fenômenos e suas leis, ao invés de apenas descrevê-los ou memorizá-los algoritmicamente, inevitavelmente, ocorre a superação das fronteiras disciplinares, pois elas têm formas muito semelhantes de se constituírem: "Ora, a partir do momento em que ultrapassamos o observável para iniciarmos a busca dessas coordenações necessárias, segue-se que, mais cedo ou mais tarde, ultrapassamos as fronteiras da ciência em causa e penetramos no domínio das ciências vizinhas" (Piaget, 2006, p. 59, grifo nosso). A epistemologia construtivista de Piaget busca desvelar o processo de construção do conhecimento, apontando para a unidade das ciências. Uma unidade que, ao que parece, pode ser construída pela apropriação do próprio sujeito. Tais pensamentos são também comuns a Jantasch e Bianchetti, ao afirmarem que:

À idéia de que somente é possível ser interdisciplinar em grupo, contrapomos a de
que a sós também é possível. Um grupo pode ser mais homogêneo e superficial que
o indivíduo que busca recursos de várias ciências para explicar determinado
processo, são bons exemplos as obras de Marx, Piaget, Gramsci, Weber, Florestan
Fernandes e outros (Jantsch; Bianchetti, 1995, pp. 23-24).

Ainda que de forma mais empírica, encontramos idéias semelhantes na Teoria Geral dos Sistemas de Bertalanffy (1977). Este autor reporta uma teoria capaz de ser aplicada nas várias áreas do conhecimento na busca da integralidade. Para tanto, ele investigou os isomorfismos de conceitos (leis e modelos) em diversos campos, promovendo transferências úteis de um campo para outro, com o propósito de favorecer o desenvolvimento de modelos teóricos adequados a outros campos do conhecimento. Uma teoria que, segundo Bertalanffy julgava ser capaz de: 
- integrar as várias ciências, naturais e sociais;

- trazer exatidão nos campos não físicos da ciência;

- reduzir a possibilidade de duplicação de esforços teóricos em campos diferentes;

- promover a unidade da ciência, melhorando a comunicação entre os especialistas;

- desenvolver princípios unificadores que perpassem "verticalmente" o universo das ciências individuais em busca da unidade;

- conduzir a uma integração na educação científica (Bertalanffy, 1977; 2006; Uhlmann, 2002).

Bertalanffy defendia uma formação de cientistas com capacidades mais generalizadoras, conhecedores de princípios interdisciplinares:

\begin{abstract}
Muitas vezes ouvimos dizer que um único homem não pode mais abranger um campo bastante amplo e que há demasiada especialização estreita... Precisamos de uma abordagem mais simples, mais unificada dos problemas científicos, precisamos de homens que pratiquem a ciência e não de uma ciência particular, numa palavra precisamos de generalistas científicos (Bertalanffy, 1977, p. 77).
\end{abstract}

Na busca dessa unidade aparecem também as idéias do filósofo humanista Georges Gusdorf (1984), que apresentou à Unesco um projeto em que propunha que a pesquisa teórica tivesse por base a unidade nas ciências humanas ${ }^{7}$. Essa unidade seria considerada como básica para definir o domínio de uma pesquisa fundamentalmente integradora. Esse propósito integrador, segundo Gusdorf, poderia trazer contribuições favoráveis para o futuro de cada ciência em particular, pois as questões a serem investigadas contariam com a colaboração de todas as disciplinas, ou de algumas, o que certamente ampliaria o campo de compreensão sobre o objeto de estudo.

Os problemas humanos são abordados, geralmente, sob o prisma da especificidade. A pesquisa fundamental se encarregaria de abordá-lo na perspectiva da unidade ou da totalidade. Essa conversão da atenção epistemológica poderia acarretar, para ela somente, conseqüências muito importantes (Gusdorf, 1984, p. 31).

Gusdorf defendia que essa mudança de foco epistemológico deveria contribuir para o desenvolvimento das áreas do conhecimento, pois para ele, o que temos assistido até o momento é o desenvolvimento de uma ou de outra disciplina em particular.

\footnotetext{
${ }^{7}$ Gadotti (2006) considera que Gusdorf sustentava uma visão antropológica da unidade humana, pois ele buscava unificar a consciência humana, que estava fragmentada devido ao excesso de especialização.
} 
Considerando-se os conceitos mencionados (de epistemologia, de pesquisa e de filosofia), ao que tudo indica, os autores selecionados, como Piaget, Jantasch, Bianchetti e Bertalanffy defendem a idéia de um domínio de alguns campos disciplinares pelo próprio sujeito. Alguns autores nacionais que trabalham com a interdisciplinaridade mostram a influência da literatura apontada até aqui.

Segundo Ivani Fazenda, na década de 70 as propostas interdisciplinares traziam um sentido de unidade, uma vez que buscavam a convergência entre o papel humanista do conhecimento e da ciência. "A intenção desse projeto seria orientar as ciências humanas para a convergência de trabalhar a unidade humana" (Fazenda, 1994, p. 19). Idéias que, segundo ela, trouxeram alguns equívocos nessa época, quando se começou a pesquisar a interdisciplinaridade, em que se pressupunham acabar com as disciplinas em nome de uma pseudo-integração ${ }^{8}$ (Fazenda, 1994; 1993).

Por outro lado, é comum encontrarmos autores que defendem uma abordagem interdisciplinar pelos sujeitos especialistas, ou seja, diversos especialistas disciplinares reunidos para esse propósito. Assim, a integração do conhecimento por um único sujeito parece conviver com propostas interdisciplinares, a partir de vários especialistas. Por exemplo, Japiassu (1976) menciona que, "a interdisciplinaridade se caracteriza pela intensidade das trocas entre os especialistas e pelo grau de interação real das disciplinas, no interior de um projeto específico de pesquisa" (Japiassu, 1976, p. 74, grifo nosso). Segundo esse autor o interdisciplinar não deve pretender ser um campo unitário do conhecimento, ou uma unidade construída pela adição das especialidades e, nem tampouco, por uma síntese dos saberes específicos. O espaço interdisciplinar deve ser construído na superação das fronteiras disciplinares. A pesquisa interdisciplinar começa a se evidenciar, segundo ele, à medida que seus participantes evoluem para uma pesquisa com uma

\footnotetext{
${ }^{8}$ Equívoco mencionado também, por $\mathrm{P}_{6}$, quando da sua participação na elaboração dos documentos oficiais: “Com relação à interdisciplinaridade, parece ser algo um pouco complicado, pois a princípio, ela foi mal compreendida; porque se entendeu que haveria a supressão das disciplinas, formando áreas de trabalho. Nas primeiras reuniões para a elaboração dos documentos de conhecimento em física, foi um pouco chocante, pois julgava-se haver uma idéia de uma grande área que subjazia nas propostas dos documentos. Tais indícios se revelavam nos Parâmetros Curriculares Nacionais, ao intencionar formar três áreas de conhecimento. A interdisciplinaridade parecia propor a formação de professores por área. Afinal, esses documentos traziam um discurso da Secretaria do Governo e do MEC, e na época o BID (Bando de Desenvolvimento Interamericano) atuava intensamente nos projetos de financiamento da educação, sendo que no Brasil havia uma proposta, em que se atribuía à educação, duas funções principais: domínio da língua e o domínio da matemática” (p.149, informação pessoal-Apêndice 2).
} 
produção de uma linguagem comum. Pontos essencialmente defendidos por Gusdorf, ao afirmar que trabalhos interdisciplinares autênticos devem evoluir para a construção de uma metodologia, procedimentos e linguagem comuns, sendo a condição para o surgimento de um saber novo, uma autêntica produção interdisciplinar. $\mathrm{O}$ interesse no interdisciplinar, segundo Gusdorf, inscreve-se numa situação epistemológica, em que: “[...] a inteligência interdisciplinar só se encontrará no ponto de chegada da investigação [...], se estiver presente desde o começo" (Gusdorf, 2006, p. 53, grifo nosso). Assim, para esse autor, imaginar que a consciência interdisciplinar possa ser alcançada pelo especialista com tributo do seu trabalho é um equívoco, pois se a preocupação da unidade humana do saber não é considerada no ponto de partida da investigação, certamente não se encontrará no ponto de chegada.

Por outro lado, para Santomé: “A interdisciplinaridade é um objetivo que nunca é completamente alcançado e por isso deve ser permanentemente buscado. Não é apenas uma proposta teórica, mas sobretudo uma prática. Sua perfectibilidade é realizada na prática; na medida em que são feitas experiências reais de trabalho em equipe (...)" (Santomé, 1998, p. 66). Assim, ela se põe como uma metodologia, que não depende somente das disciplinas, pois está associada a certos "traços da personalidade", como: flexibilidade, confiança, paciência, capacidade de adaptação, aceitação de riscos e capacidade de aprender a agir na diversidade. Uma proposta de trabalho que está diretamente relacionada ao nível de conhecimento, flexibilidade e convergência dos participantes na sua consecução (Santomé, 1998). Características muito comuns ao pensamento de Fazenda (1994; 1993), ao propor a interdisciplinaridade como uma relação de reciprocidade, de mutualidade, ou melhor, um regime de co-propriedade que possibilita o diálogo entre os interessados. Neste sentido, pode-se dizer que a interdisciplinaridade depende basicamente de uma atitude, traduzida entre o diálogo dos interessados e co-responsáveis pelo processo interdisciplinar. Uma atitude que se constrói na prática, superando a dicotomia (teoria e prática), algo que pode ser observado na pesquisa. Esse diálogo interdisciplinar, entretanto, deve ser feito com a presença das disciplinas. Suas críticas não são direcionadas às disciplinas, mas aos recortes excessivos nos conteúdos, os quais, impossibilitam a compreensão na sua essencialidade.

Machado (2002; 2001), por sua vez, considera quatro dimensões nas propostas integradas, as quais podem ser agrupadas em: 


\begin{abstract}
- Multidisciplinaridade, os objetivos próprios de cada disciplina são preservados, conservando-se sua autonomia, seus objetos, sendo tênues as articulações entre as mesmas;

- Interdisciplinaridade, busca-se o estabelecimento de uma intercomunicação efetiva entre as disciplinas, por meio do enriquecimento das relações entre elas. Almeja-se, a composição de um objeto comum, por meio dos objetos particulares de cada uma das disciplinas participantes;

- Intradisciplinaridade, as progressivas particularizações do objeto de uma disciplina dão origem a uma ou mais subdisciplinas, que não chegam verdadeiramente a deter uma autonomia, nem no que se refere ao método nem quanto ao objeto;

- Transdisciplinaridade, a constituição de novo objeto dá-se em movimento ascendente, de generalização (Machado, 2002, pp. 135-136).
\end{abstract}

No eixo multi/interdisciplinar, as unidades disciplinares são conservadas. Ocorre um avanço na interação, em que as disciplinas se debruçam sobre um problema comum (objeto), convidando as demais a contribuírem para aumentar o sentido daquilo que se propõem estudar. A interdisciplinaridade pressupõe um aumento das relações entre as disciplinas, pois não é razoável que as disciplinas trabalhem sem se relacionar, ou com fracas interações. Então, o que se busca é esse aumento de interação; intenciona-se uma composição de um objeto comum, por meio das contribuições disciplinares, com um enriquecimento mútuo dos participantes. No eixo intra/transdisciplinar, a característica básica das relações estabelecidas é a verticalidade. De um lado, ocorre o afunilamento no sentido da especificidade da disciplina; no outro, o olhar se dá numa perspectiva maior, não se detendo exclusivamente no objeto das disciplinas. O espectro se amplia para questões como mapeamento genético, ética educacional, antropologia etc; questões relacionadas com a pessoalidade. Na transdisciplinaridade, a idéia é algo além das disciplinas, propostas que entram em confluência com os pensamentos de Edgar Morin (2001; 2002), o qual menciona a necessidade da interdisciplinaridade na compreensão do objeto, insistindo no avanço das relações nos domínios da Física, Biologia e Antropossociologia?

Zabala (2002, 1998), entende a interdisciplinaridade como uma cooperação entre diversas disciplinas, que se traduz em um mesmo conjunto de conceitos e métodos de investigação. Assim:

A interdisciplinaridade é a interação de duas ou mais disciplinas, que pode ir desde a simples comunicação de idéias até a integração recíproca dos contextos fundamentais e da teoria do conhecimento, da metodologia e dos dados de

\footnotetext{
${ }^{9}$ Para Morin "é necessário enraizar o conhecimento físico e biológico numa cultura, numa sociedade, numa história, numa humanidade. A partir daí cria-se a possibilidade de comunicação entre as ciências" (Morin, 2002, p. 54).
} 
pesquisa. Estas interações podem implicar transferências de leis de uma disciplina para outra e, inclusive, em alguns casos dão lugar a um novo corpo disciplinar, como a bioquímica ou a psicolingüística. Podemos encontrar esta concepção na configuração das áreas de Ciências Sociais e Ciências Experimentais no ensino médio e da área de Conhecimento do meio no ensino fundamental.

Zabala menciona que a inter-relação das disciplinas com suas especificidades pode proporcionar uma maior compreensão da realidade, a qual é sempre de natureza complexa.

Assim, observamos várias concepções de propostas interdisciplinares. Interações que podem ser feitas pelo sujeito, ou entre os sujeitos na busca de uma maior compreensão da realidade. Concepções, com viés filosófico, epistemológico e metodológico. Tais conceitos, porém, longe de se apresentarem como uma evolução ou transformação cronológica nessas décadas, convivem em tempos comuns, evidenciando mais e mais se tratarem de um termo polissêmico ${ }^{10}$.

\footnotetext{
${ }^{10}$ De acordo com o dicionário eletrônico Houaiss: Do latim. Científico: polysemia: "que tem muitas significações".
} 


\section{Capítulo 3 - A interdisciplinaridade nos documentos oficiais}

Neste capítulo faremos um estudo dos documentos educacionais oficiais brasileiros com o objetivo de compreender o que as políticas públicas educacionais contempladas nestes documentos reservam para as propostas de currículo integrado (interdisciplinares) e quais as concepções recomendadas por esses documentos.

Para tanto, faremos inicialmente uma análise dos documentos oficiais:

3.1- Lei de Diretrizes e Bases da Educação Nacional no 9.394/96, no título V, capítulo II, seção IV, que dispõe sobre o Ensino Médio, LDB (Brasil, 1998).

3.2- Parâmetros Curriculares Nacionais para o Ensino Médio, PCNEM (Brasil, 1999).

3.3- PCN+ Ensino Médio Orientações Educacionais Complementares aos Novos Parâmetros Curriculares Nacionais-Ciências da Natureza, Matemática e suas Tecnologias, PCN+ (Brasil, 2002).

3.4- Documento Orientações Curriculares para o Ensino Médio-OCEM (Brasil, 2004) e Documento Orientações Curriculares para o Ensino Médio-Ciências da Natureza, Matemática e suas Tecnologias - OCEM (Brasil, 2006). 


\subsection{A LDB e a Interdisciplinaridade: o que a Lei aponta para essa modalidade de ensino}

Decorridas mais de duas décadas da implementação da última Lei de Diretrizes e Bases da Educação Nacional (LDB), a publicação da Lei 9.394/96 ${ }^{11}$ emerge no cenário educacional como resposta às expectativas e necessidades de todos aqueles que se empenham no propósito de educar. A LDB estabelece o caráter do Ensino Médio como etapa final da Educação Básica e o Estado passa a assumir a responsabilidade na oferta desse nível de ensino a todos os brasileiros, pois esta modalidade de ensino começa a fazer parte da Educação Básica. No que diz respeito à sua finalidade, o Ensino Médio deixa de ser voltado exclusivamente para o prosseguimento dos estudos, ou de certa forma a habilitar para uma formação técnica. Segundo a LDB, o Ensino Médio deverá se vincular ao mundo do trabalho e ao prosseguimento dos estudos. O artigo 35 da referida lei, considera o Ensino Médio etapa final da Educação Básica, com duração de três anos e tem como finalidades:

\footnotetext{
I A consolidação e o aperfeiçoamento dos conhecimentos adquiridos no ensino fundamental, possibilitando o prosseguimento de estudos;

II A preparação básica para o trabalho e a cidadania do educando, para continuar aprendendo, de modo a ser capaz de se adaptar com flexibilidade a novas condições de ocupação, ou aperfeiçoamento posteriores;

III O aprimoramento do educando como pessoa humana, incluindo a formação ética e o desenvolvimento da autonomia intelectual e do pensamento crítico;

IV A compreensão dos fundamentos científico-tecnológicos dos processos produtivos, relacionando a teoria com a prática, no ensino de cada disciplina (Brasil, 1998).
}

Compreendida a formação cidadã e a capacidade de continuar aprendendo, vamos ao parágrafo $1^{\circ}$, artigo 26 da Lei que trata do currículo "Os currículos do ensino fundamental e médio devem ter uma base nacional comum, a ser complementada, em cada sistema de ensino e estabelecimento escolar, por uma parte diversificada, exigida pelas características regionais e locais da sociedade, da cultura, da economia e da clientela. [...] Os currículos a que se refere o caput devem abranger, obrigatoriamente, o estudo da língua portuguesa e da matemática, conhecimento do mundo físico e natural e da realidade social e política, especialmente do Brasil” (Brasil, 1998, pp. 11-12).

\footnotetext{
${ }^{11}$ Publicada no Diário Oficial da União, de 23 de dezembro de 1996.
} 
Já no artigo 36, que trata da etapa final da educação básica, especificamente o Ensino Médio:

[...] destacará a educação tecnológica básica, a compreensão do significado da ciência, das letras e das artes; o processo histórico de transformação da sociedade e da cultura; a língua portuguesa como instrumento de comunicação, acesso ao conhecimento e exercício da cidadania (Brasil, 1998, p. 15).

Os referidos artigos mencionam a obrigatoriedade do estudo de língua portuguesa, de matemática e do conhecimento do mundo físico. Tais apontamentos podem sinalizar para a criação de áreas do conhecimento, e por decorrência a integração delas, numa perspectiva interdisciplinar. Entretanto, explicitamente, a Lei não menciona esse propósito e não faz referência à interdisciplinaridade.

\subsection{Os Parâmetros Curriculares Nacionais e a Interdisciplinaridade}

O Brasil participou na década de 90 da Conferência Mundial da Educação para Todos, ocorrida na Tailândia. Na ocasião assinou a Declaração de Nova Délhi, em que se compromete garantir às crianças, jovens e adultos uma educação básica de qualidade. Esse compromisso, somado à análise real dos problemas da educação brasileira levou o governo a estabelecer o Plano Decenal de Educação para Todos (1993-2003), cujo objetivo principal é o de recuperar a qualidade do ensino, num processo de aprimoramento contínuo (Youssef e Soncini, 2006).

Buscando nortear a educação em todo o território brasileiro, a fim de que ela se desenvolva de acordo com as intenções e finalidades da LDB, os parâmetros curriculares (PCNEM) dispõem que:

\footnotetext{
- Os estados e municípios estabelecem os conteúdos adequados às suas necessidades sócio-culturais e à melhor forma de distribuí-los ao longo da escolaridade;

- Escolas e professores definem um projeto pedagógico, com objetivos, conteúdos e critérios de avaliação, e planejam suas aulas de acordo com as necessidades de seus grupos de alunos (Brasil, 1999).
}

Os documentos ressaltam a necessidade de um conjunto de conhecimentos, que devem ser ensinados a todos os alunos, assegurando uma formação comum. Todavia, em virtude da extensa territorialidade brasileira, com muitas realidades e problemas específicos em 
cada contexto, os parâmetros asseguram um núcleo diversificado, para atender essas múltiplas realidades.

No tocante aos conteúdos, sua seleção deverá representar mais do que uma simples listagem de tópicos a serem desenvolvidos. Essa escolha se dará de acordo com as intenções educativas.

Mais do que fornecer simples informações, o Ensino Médio, segundo o PCNEM deve se voltar ao desenvolvimento de competências básicas, tanto para o exercício da cidadania quanto para o desempenho de atividades profissionais, na perspectiva de uma aprendizagem permanente e de uma formação contínua. O currículo deve apresentar conteúdos que permitam o desenvolvimento de competências, como a capacidade de: buscar, selecionar e organizar informações; propor soluções para problemas apresentados; ser capaz de trabalhar em equipe; saber comunicar-se; fazer uso dos conhecimentos adquiridos para elaborar críticas; argumentar com fundamentos; ser capaz de relacionar diferentes fenômenos dentro de uma disciplina, entre disciplinas de uma área e entre as áreas do conhecimento escolar, construindo pensamento orgânico/sistêmico (Brasil, 1999).

Buscando maior articulação entre os conteúdos, os Parâmetros Curriculares Nacionais do Ensino Médio-PCNEM (Brasil, 1999) propõem que os currículos a serem definidos pelos estados, municípios e escolas estejam organizados em três áreas: Linguagens, Códigos e suas Tecnologias, Ciências da Natureza, Matemática e suas Tecnologias e Ciências Humanas e suas Tecnologias. A organização em áreas tem como base a reunião dos conhecimentos que compartilham objetos de estudo, facilitando a comunicação e criando condições para que possam se desenvolver trabalhos numa perspectiva interdisciplinar. A estrutura por área de conhecimento garante uma educação de base científica e tecnológica, em que as possíveis soluções para os problemas concretos, são combinadas e orientadas numa visão epistemológica que concilie humanismo e tecnologia (Brasil, 1999).

Segundo Lopes e Macedo (2002), o enfoque na interdisciplinaridade no Ensino Médio se evidencia, a partir do momento que os parâmetros acenam com a criação das três áreas do conhecimento: Linguagens e Códigos e suas Tecnologias (língua portuguesa, língua estrangeira moderna e educação física, arte e informática); Ciências da Natureza, Matemática e suas Tecnologias (química, física, biologia e matemática); Ciências Humanas 
e suas Tecnologias (história, geografia, sociologia, antropologia, política e filosofia). A partir desse momento o documento busca explicitamente conviver a interdisciplinaridade com a disciplinaridade. O documento justifica a formação em áreas, ao expressar que "tem por base a reunião daqueles conhecimentos que compartilham objetos de estudo e, portanto, mais facilmente se comunicam, criando condições para que a prática escolar se desenvolva numa perspectiva interdisciplinar" (Brasil, 1999, p. 39).

O PCNEM-1999 pretende que na Educação Básica o aluno seja capaz de construir um pensamento estruturado, fazendo-se necessário repensar a organização curricular com relação ao modo como as diferentes disciplinas estão dispostas, pois os conteúdos separados permitem que o aluno compreenda apenas parte da situação ou do objeto em estudo. Dessa forma, é expresso no documento que uma maior compreensão decorre, quando relações entre conteúdos das diferentes disciplinas se estabelecem numa abordagem interdisciplinar. A interdisciplinaridade defendida pelo documento é assim apresentada:

\footnotetext{
A interdisciplinaridade deve ir além da mera justaposição de disciplinas, e ao mesmo tempo, evitar a diluição delas em generalidades. De fato, será principalmente na possibilidade de relacionar as disciplinas em atividades, ou projetos de estudo, pesquisa e ação, que a interdisciplinaridade poderá ser uma prática pedagógica e didática adequada aos objetivos do Ensino Médio.

$\mathrm{O}$ conceito de interdisciplinaridade fica mais claro quando se considera o fato trivial de que todo o conhecimento, que pode ser de questionamento, confirmação, de complementação, de negação, de ampliação, de iluminação de aspectos não distinguidos.

[...] A interdisciplinaridade também está envolvida quando os sujeitos que conhecem, ensinam e aprendem sentem, necessidade de procedimentos que, numa única visão disciplinar, podem parecer heterodoxos, mas fazem sentido quando chamados a dar conta de temas complexos (Brasil, 1999, p. 132).
}

Essas inter-relações “(...) entre as disciplinas tradicionais pode ir da simples comunicação de idéias até a integração mútua de conceitos, da epistemologia, da terminologia, da metodologia e dos procedimentos de coleta e análise de dados" (Brasil, 1999, p. 88, grifo nosso).

Observamos que a interdisciplinaridade deve ser compreendida, a partir de uma abordagem relacional em que se propõe que, por meio da prática escolar, ocorra estabelecimento de interconexões, integrando as disciplinas, criando condições favoráveis para uma aprendizagem motivadora, na medida em que se oferece maior incentivo aos educadores para desenvolverem conteúdos diretamente relacionados ao contexto social. 
No tocante à contextualização o PCNEM considera uma necessidade para a significação do que se pretende conhecer. Contextuar os conteúdos é um recurso que contribui para que os alunos atuem sobre sua aprendizagem, uma vez que os provoca, os instiga a elaborar hipóteses, a buscar informações, a confrontar diferentes idéias, diferentes explicações, a perceber os limites de cada explicação, inclusive daquelas que eles já possuem, na perspectiva da construção de seu conhecimento. Nesse sentido, o conhecimento escolar não pode estar desvinculado de elementos da vida pessoal, social e cultural, pois os conteúdos escolares ganham sentido quando se constroem conexões entre o que se aprende na escola e o cotidiano (Brasil, 1999).

Ao apontar para uma integração entre as disciplinas, para atuar com maior compreensão na realidade, a concepção de interdisciplinaridade defendida pelo documento PCNEM-1999 aparentemente remete-nos aos conceitos de estruturas subjacentes de Piaget já apresentados anteriormente (Piaget, 1978, pp. 12-26). Piaget defende ser possível romper com as barreiras disciplinares e caminhar no sentido de uma visão interdisciplinar, em que o professor possa fazer algumas superações epistemológicas. Tais superações devem ser entendidas como a capacidade de conhecer com sentido e significado parte dos conteúdos de outras disciplinas. No que se refere ao "O sentido do aprendizado nas áreas" (parte III), o documento traz como objeto de aprofundamento dos saberes disciplinares uma proposta de articulação interdisciplinar, através dos conteúdos científicos, tecnológicos e práticos, presentes na área, os quais são mencionados como potencializadores de atividades integradoras. Uma aproximação das disciplinas, que não elimina e nem dilui os conhecimentos disciplinares, podendo ser feita: “(...) em cada disciplina e nas disciplinas e no conjunto de disciplinas, em cada área e no conjunto das áreas. Mesmo dentro de cada disciplina, uma perspectiva mais abrangente pode transbordar os limites disciplinares" (PCNEM, 1999, p. 211, grifo nosso).

$\mathrm{Na}$ área específica do conhecimento de Biologia existe a pretensão de se estudar a vida em sua diversidade de manifestação, em uma abordagem que vai do sistema (célula, indivíduo etc.) até a sua relação como meio no qual está inserido. Para isso, entende-se a necessidade de projetos capazes de articular os conteúdos de outras disciplinas: 
possibilitando ao aluno relacionar conceitos nessas disciplinas, numa conceituação mais ampla de ecossistema (PCNEM, 1999, p. 229).

O ensino de Física objetiva contribuir para uma formação de uma cultura científica, que possibilite ao educando a interpretação dos fatos, fenômenos e processos naturais. Para isso, propõe um conhecimento integrado à vida dos jovens, uma vez que o mundo real não é em si mesmo disciplinar. Nesta ótica espera-se que o educando seja capaz de extrapolar conceitos: “[...] reconhecer o significado de tempo como parâmetro físico, por exemplo, deve ser acompanhado da capacidade de articular esse conceito com os tempos envolvidos nos processos biológicos ou químicos [...]" (PCNEM, 1999, p. 232).

O ensino de Química intenciona que o aluno do Ensino Médio compreenda as transformações químicas que ocorrem no mundo físico de forma integrada, pois o conhecimento químico isolado é importante, porém insuficiente para o entendimento desse mundo. Neste sentido, incentiva-se o estudo por temas que permitem uma contextualização dos conhecimentos. Essa inserção na realidade pode ser feita a partir da hidrosfera, litosfera e biosfera, permitindo uma inter-relação com outras disciplinas, uma vez que esses assuntos: “[...] requerem não só o conhecimento específico, mas fundamentalmente o entendimento do resultado das interações entre os conhecimentos químicos e os conhecimentos físicos, biológicos e geológicos" (Brasil, 1999, p. 247).

Ao ensino de Matemática é atribuída a capacidade de desenvolver o raciocínio dedutivo, sendo uma ferramenta no auxílio das tarefas da vida humana, devendo ser vista pelo educando como um conjunto de técnicas e estratégias para serem aplicadas a: “[...] outras áreas do conhecimento, como a Física, Geografia ou Economia. [...]” (PCNEM, 1999, p. 257).

O documento (PCNEM-1999) defende ainda uma interação entre as disciplinas, mas preserva a sua identidade e especificidade. As disciplinas são convidadas a contribuir no sentido de aumentar a compreensão sobre o objeto de estudo. Com relação à abordagem interdisciplinar, observamos indícios de uma proposta em que o próprio sujeito faz o diálogo com as outras disciplinas, uma vez que o documento enfatiza a necessidade de relacionar conceitos para melhor compreensão do objeto de estudo e remete-se às idéias de estruturalismo de Piaget. 


\subsection{Novas orientações para o Ensino Médio: Orientações Educacionais Complementares-PCN+}

O documento PCN+ Ensino Médio: Orientações Educacionais Complementares aos Parâmetros Curriculares Nacionais traz uma ênfase nas áreas do conhecimento, subdividindo-se em: Linguagens Códigos e suas Tecnologias, Ciências da Natureza, Matemática e suas Tecnologias e Ciências Humanas e suas Tecnologias (Brasil, 2002). Esse documento busca contribuir para a implementação das reformas educacionais definidas pela nova LDB 9.394/96, regulamentada pelas Diretrizes do Conselho Nacional de Educação (CNE), que tem como propostas centrais, facilitar a organização do trabalho escolar sugerindo a formação de áreas do conhecimento. Para isso, propõe uma articulação nas e entre as áreas, com o domínio de competências gerais (comunicar e representar, investigar e compreender e contextualizar historicamente) e habilidades específicas, que se deseja promover com os conhecimentos disciplinares. O documento propõe o diálogo entre áreas para a articulação das competências que deseja desenvolver através dos conteúdos, além de apoiar o professor na sua prática e subsidiar sua formação contínua, o que se espera conseguir com a articulação entre as áreas do conhecimento.

Assim, mesmo com a necessidade de transformações de caráter econômico, social ou cultural que levaram à modificação da escola no Brasil e no mundo, não se propõe a extinção das disciplinas, mas sugere-se a organização e a interligação nas três áreas Ciências da Natureza e Matemática, Ciências Humanas e Linguagens e Códigos - que interligam as disciplinas, mas não as diluem nem as eliminam.

A articulação entre as áreas é uma clara sinalização para o projeto pedagógico da escola, o qual envolve uma sintonia de tratamentos metodológicos e pressupõe a composição do aprendizado de conhecimentos disciplinares com o desenvolvimento de competências gerais. Essa integração de metas formativas necessita para sua realização de projetos interdisciplinares, nos quais diferentes disciplinas tratem ao mesmo tempo de temas afins, sendo indispensável o estabelecimento de metas comuns, envolvendo cada uma das disciplinas de todas as áreas, a serviço do desenvolvimento humano dos alunos e também dos professores (Brasil, 2002). 
Ao assumir que as disciplinas devem ser mobilizadas com a intenção de produzir um ensino relacionado com o universo vivencial do educando, o documento sugere uma articulação desses saberes através de temas estruturadores, como: Universo, Terra, Vida, Biosfera, Transformações etc., pela facilidade que eles encontram de transitar por múltiplas disciplinas. A respeito de como essa articulação entre as áreas do conhecimento pode ser alcançada, o documento menciona que: “[...] a idéia de que a perspectiva interdisciplinar de conteúdos educacionais apresentados com o contexto no âmbito de uma ou mais áreas, não precisa necessariamente de uma reunião de disciplinas, pois pode ser realizada por uma única" (Brasil, 2002, p.17, grifo nosso). Essa intencionalidade pode ser observada, também no item que trata do propósito de cada disciplina.

O ensino de biologia, por exemplo, faz menção às estratégias de ação, incentivando o desenvolvimento de projetos, os quais mesmo tendo perspectivas amplas de desenvolvimento podem ser abordados a partir dos conhecimentos da disciplina de Biologia: "Tal projeto, com característica inter ou transdisciplinares, pode ser desenvolvido, por exemplo, apenas no âmbito da Biologia" (Brasil, 2002, p. 56, grifo nosso).

O ensino de Física sugere também, uma abordagem por temas, entendendo que eles são mais adequados ao desenvolvimento de competências, ao mesmo tempo em que se busca um ensino de Física voltado ao universo vivencial do educando. Nessa perspectiva os temas geradores podem ser estruturados em: Movimento, variações e conservações; Calor, ambiente e usos de energia; Som, imagem e informação; Equipamentos elétricos e telecomunicações; Matéria e radiação; Universo, Terra e vida, pois permitem uma reorganização dos conteúdos tradicionais, como Mecânica, Termologia, Eletromagnetismo e Física Moderna, possibilitando atribuir-lhes novos sentidos. Esses temas podem ser abordados por inúmeras inter-relações com as demais áreas: "O estudo do som pode ainda permitir uma interface importante com as artes, a música e em particular, ou, ainda o reconhecimento dos vários instrumentos associados a diferentes culturas”, tendo uma abordagem física com transição nas diversas áreas (Brasil, 2002, p. 70). Esse diálogo pode ser estruturado, através de projetos que promovam uma intervenção na realidade, com a presença ativa do educando, com a participação de profissionais, especialistas, cientistas e tecnólogos. 
O ensino de Química, por sua vez, traz especial atenção para as atividades experimentais, estudos do meio, diversificação de materiais ou recursos didáticos. É interessante verificar que o desenvolvimento de Temas Geradores, ou Projetos contemplam, se não todas, mas várias das estratégias sugeridas, segundo esse documento:

\begin{abstract}
O desenvolvimento de projetos disciplinares, ou interdisciplinares, articulando todas essas formas de ação ou recursos pedagógicos, é extremamente propício para o desenvolvimento das diferentes competências almejadas, particularmente aquelas associadas à contextualização sócio-cultural: selecionar um tema de relevância científica, tecnológica, social ou cultural associado ao conhecimento químico, programar suas diferentes etapas, dividir tarefas e responsabilidades no grupo, buscar e trocar informações prévias, desenvolver as ações previstas, avaliá-las e relatá-las, usando diferentes meios e instrumentos de comunicação, interagir com outras comunidades (Brasil, 2002, p.109).
\end{abstract}

Dessa forma, o trabalho interdisciplinar sugere necessariamente um enraizamento no contexto, que pode ser explicado pela mobilização das disciplinas.

$\mathrm{O}$ estudo da produção industrial de algum material pode se iniciar como um projeto disciplinar e permitir a integração de vários conhecimentos de outras áreas tratados neste tema. A área de Matemática pretende que o educando aprenda de forma contextualizada, integrada e relacionada com outros conhecimentos, buscando desenvolver as competências desejadas a essa modalidade de ensino. Assim, o ensino de matemática intenciona capacitar o educando a compreender e interpretar situações e apropriar-se de linguagens específicas, como argumentar, analisar, avaliar etc. Seu foco de estudo, a exemplo das demais áreas, são os temas estruturadores, privilegiando o tratamento de situações-problemas presentes na realidade do educando. Dessa maneira, o ensino de matemática mesmo tendo as suas especificidades, serve de instrumento para as demais disciplinas (Brasil, 2002).

O documento menciona ainda, a necessidade de autoformação dos professores em sintonia com as exigências profissionais do século XXI, acenando para a formação permanente e em serviço do professor:

Afinal o que se pretende, o que se deseja, afinal, são professores reflexivos e
críticos, ou seja, professores com um conhecimento satisfatório das questões
relacionadas ao ensino-aprendizagem e em contínuo processo de autoformação,
além de autônomos e competentes para desenvolver o trabalho interdisciplinar. Um
dos instrumentos úteis a essa reflexão baseia-se em procedimentos de auto-
observação e análise, em que se destaca a importância de o professor saber o que
faz em sala de aula e de saber por que faz dessa forma e não de outra. Na reflexão
sobre a própria prática, acabam emergindo também traços da história de vida dos 
profissionais, que podem conduzir reflexões sobre as crenças que permeiam seu conceito de ensino e aprendizagem. Pensar e repensar o discurso e a prática, individual ou coletivamente, nos relatos em grupos da biografia profissional de cada professor, num movimento cooperativo, de co-responsabilidade e negociação, poderá levar à convergência para o aperfeiçoamento profissional e, em última análise, para a construção da escola pretendida (Brasil, 2002, p.144).

Esse espaço de formação deve ser planejado e fazer parte do plano político pedagógico da escola, pois é nele que as necessidades reais estão postas, e não nos parece fora de propósito a idéia de um professor/reflexivo e crítico da sua prática. Aquele que, numa discussão, aponta os problemas para coletivamente encontrar soluções e, refletindo sobre o problema, propõe novas estratégias para abordar o conteúdo (Maldaner, 2003; Schön, 2000 e Nóvoa, 1999). Ao fazer menção sobre a necessidade de uma reflexão individual/coletiva, esse documento acena para uma inevitável criação de "espaços" para a sua efetivação.

$\mathrm{O} \mathrm{PCN}+$ aponta para a necessidade de articulação entre as áreas, em função do desenvolvimento de competências. Nota-se que o conteúdo, a interdisciplinaridade e a contextualização são mobilizados, com a finalidade de facilitar as interconexões entre as áreas. Outro ponto marcante neste documento é a menção explícita de que a interdisciplinaridade pode ser desenvolvida por um professor de uma única disciplina, ou seja, admite-se a possibilidade de algumas superações epistemológicas, onde o mesmo professor desenvolve conteúdos de outras disciplinas. Essa menção pode ser constatada na seção que trata dos "Conhecimentos, competências, disciplinas e seus temas estruturadores", sendo observada também nas áreas de Biologia e Química e inferida nas demais.

\subsection{Orientações Curriculares para o Ensino Médio (OCEM de 2004 e 2006)}

Neste momento faremos uma releitura dos Documentos Oficiais (LDB, PCNEM e $\mathrm{PCN}+$ ) tomando como apontamento o documento "Orientações Curriculares para o Ensino Médio", OCEM (Brasil, 2004; 2006) e abordaremos as suas concepções de interdisciplinaridade.

O documento OCEM tem um percurso histórico iniciado com o Seminário Médio: Construção Política, realizado no ano de 2003 pelo Ministério da Educação e Cultura (MEC), com os representantes das sociedades científicas e da Secretaria de Educação 
Média e Tecnológica (SEMTEC) para as discussões que deveriam nortear um Fórum do Ensino Médio. Para a SEMTEC esse evento serviria como um instrumento indutor, para que as sociedades científicas discutissem o Ensino Médio. Nesse sentido, "os Parâmetros Curriculares Nacionais seriam objeto de leitura e de revisão analítica, a partir de diálogos com a sociedade" (Brasil, 2004, p. 207). Decorrida essa fase, o MEC, por meio do Departamento de Políticas de Ensino Médio da Secretaria de Educação Básica, constituiu "Grupos de Trabalho" coordenados por especialistas das diversas áreas, com a finalidade de analisar os Parâmetros Curriculares Nacionais do Ensino Médio (PCNEM). Tal iniciativa culminou na elaboração do documento supracitado, que tem como propósito subsidiar educadores e professores no processo de ensino-aprendizagem. Finalmente, no ano de 2006 as "Orientações Curriculares para o Ensino Médio" foram elaboradas, a partir de ampla discussão com as equipes técnicas dos sistemas estaduais de educação. Atualmente, o material se compõe de três volumes: Linguagem, Códigos e suas Tecnologias; Ciências da Natureza, Matemática e suas Tecnologias e Ciências Humanas e suas Tecnologias, que tem como objetivo elucidar as intencionalidades dos documentos anteriores e contribuir de alguma forma com a mudança da prática docente.

Os elaboradores e consultores do documento OCEM ressaltam que, os pressupostos teórico-metodológicos dos PCNEM têm sido objeto de críticas e defesas no que se refere às concepções relativas ao processo ensino-aprendizagem. Uma das críticas refere-se à premissa equivocada de supor que seja possível o desenvolvimento de competências para o exercício da cidadania sem o desenvolvimento de conteúdos específicos das áreas do conhecimento. A outra está relacionada com a perspectiva de se trabalhar interdisciplinarmente no desenvolvimento de competências, implicando no fim das disciplinas, o que certamente configura-se noutro engano. O problema intensifica-se, pois, a noção de competência pressupõe a diversidade de concepções pedagógicas. Em que pesem as diversas visões, observa-se que esses diferentes conceitos permanecem interligados em contraposição ao chamado conteudismo baseado no modelo transmissão-recepção. $\mathrm{O}$ conceito de competência tem sofrido duras críticas; sobretudo, a concepção de competência técnica, a qual tem sido tributária de subjugar-se aos interesses do mercado econômicoglobalizador. No entender de Lopes: “(...) trata-se de uma integração que visa atender às exigências do mundo produtivo e que, portanto, submetem os saberes articulados às 
mesmas exigências e demandas de uma sociedade pós-moderna" (Lopes e Macedo, 2002, p. 150). Menção retirada em que aponta que tais competências estão intimamente relacionadas à formação das competências e habilidades necessárias ao mercado de trabalho: “[...] o currículo por competências, articulado à permanência do currículo disciplinar, compõe um discurso regulativo capaz de direcionar o processo de recontextualização do discurso instrucional e produzir o discurso pedagógico. Em outras palavras, permanece a organização disciplinar, mas nesse caso os conteúdos mostram-se submetidos às exigências das competências a serem formadas" (Lopes, 2007, p. 12).

A crítica se aplica às várias conceituações que perpassam os PCNEM, com indícios de um viés reducionista, ao se atribuir às competências um caráter de mero instrumento controlador de saberes circulantes nas escolas. Tal reducionismo desconsidera todo avanço da pesquisa no ensino de Química, por exemplo, que vem se construindo num processo crítico/reflexivo; confundindo-o com um amontoado de objetivos comportamentais de fundo tecnicista e reprodutivo de interesses dominantes, calcados na alienação das forças envolvidas no intricado modelo das relações sociais. Por outro lado, o documento ressalta que a despeito de existir, nos PCNEM, a explicitação de competências imbuídas de caráter meramente formador de mão-de-obra para o sistema produtivo e de atendimento a interesses de mercado, há aquelas, tacitamente desejáveis, que se vinculam, fundamentalmente, ao exercício da cidadania que se pretende plenamente vivenciada por parte dos egressos do Ensino Médio (Brasil, 2004; 2006).

O documento retrata que a LDB, ao propor uma formação comum nacional, rompe necessariamente, com a educação discriminatória, que propunha uma educação diferenciada para as camadas populares com a formação técnico-profissional e o da elite com uma formação propedêutica. Para tanto, foi necessário definir o que constitui a base curricular mínima nacional para cada disciplina. De acordo com o artigo 210 da Constituição Federal, "serão fixados conteúdos mínimos para o Ensino Fundamental, de maneira a assegurar formação básica comum e respeito aos valores culturais e artísticos, nacionais e regionais" (Brasil, 1998). Uma base nacional comum para assegurar a formação básica comum nacional, passa a ser incorporada ao Ensino Médio, à medida que a própria Constituição Federal estabelece a progressiva universalização desse nível de ensino. No artigo 9, ela define que a União incumbir-se-á de: [...] 
IV - estabelecer em colaboração com os Estados, o Distrito Federal e os Municípios, competências e diretrizes para a educação infantil, o ensino fundamental e médio que nortearão os currículos e seus conteúdos mínimos, de modo a assegurar formação básica comum (Brasil, 1998).

Para nortear os currículos e conteúdos mínimos, a União deverá elaborar o Plano Nacional de Educação, juntamente com Estados e Municípios.

$\mathrm{Na}$ questão da contextualização e interdisciplinaridade o documento apenas faz menção à proposta de organicidade e organização do Ensino Médio.

O documento (OCEM 2004; 2006) menciona uma coerência entre o que sugere a LDB, PCNEM e PCN+, no que se refere aos propósitos do Ensino Médio. O documento OCEM explicita que parâmetros não correspondem à unificação do currículo escolar, e nem há essa pretensão, uma vez que ele se coloca como um referencial norteador. A unificação desejada refere-se a um nível de desenvolvimento dos estudantes no final da Educação Básica. As diferenças regionais precisam e devem ser respeitadas, bem como as expectativas sociais das comunidades em que estão os estudantes. A idéia é a de preservação de um currículo nacional comum para preservar uma cultura nacional comum.

No que se refere à qualificação dos professores para avaliar o entendimento da linguagem e pressupostos teóricos dos PCNEM, o documento ressalta que foi insuficiente. Para ele, "[...] os professores não estão habilitados a compreender e analisar aprendizagem, desenvolvimento mental, flexibilidade curricular e competências” (Brasil, 2006, p. 218). Assim, constata-se que na prática não se investiu o suficiente nas condições de participação dos professores na formação contínua. $\mathrm{O}$ documento menciona que muitas produções acadêmicas sobre as ações e as compreensões dos professores da Educação Básica indicam a necessidade desses investimentos de forma sistemática e articulada com a formação inicial, com apoio às escolas, aos professores e às instituições formadoras. O documento conclui que nenhuma linguagem será adequada à mudança curricular almejada se não for resolvida a questão da participação dos professores nas decisões a serem tomadas em sua área de ensino. Com relação ao processo de trabalho, propõe-se formular uma nova concepção de Ensino Médio. Para isso, a participação dos professores e outros profissionais de ensino dos diferentes níveis seria fundamental. Desde o início, a idéia da flexibilidade estava presente e era condição para que fosse exequiível a todos os Estados da Federação. A 
primeira versão dos PCNEM (Brasil, 1999) já contemplava a organização em áreas de conhecimento, em uma perspectiva de interdisciplinaridade e de contextualização. Além disso, teriam de ser compreensíveis para os professores do Ensino Médio e terem satisfatória receptividade (Brasil, 2004).

Na prática, porém, as mudanças almejadas pelos parâmetros não se efetivaram. A justificativa mais contundente está relacionada com a falta de estudo dos documentos para efetiva apropriação por parte dos professores, como dispõe o documento:

Se, então, os PCNEM não estiverem proporcionando as mudanças almejadas, isso
não se deve aos parâmetros em si, mas às condições de atuação dos professores nas
escolas. A mesma política de estudos e participação não foi estendida aos
estabelecimentos de ensino. Dessa forma, prevalecem práticas anteriores, que
valorizam o ensino excessivamente disciplinar, descontextualizado, propedêutico,
com sequiência linear e fragmentada de conteúdos, forma já consagrada em livros
didáticos e apostilas de cursinhos preparatórios para os vestibulares. Ou seja, até
hoje pouca coisa mudou na maioria das escolas, no que se refere às modificações
propostas pelos PCNEM (Brasil, 2004, p. 221).

Essa abordagem estritamente disciplinar no ensino de Ciências da Natureza, Matemática e suas Tecnologias contribui muito pouco para a qualidade da aprendizagem. As avaliações externas, como o Exame Nacional do Ensino Médio (ENEM) revelam que os alunos não conseguem produzir respostas coerentes, a partir de dados que exigem interpretação, leitura de tabelas, gráficos, comparações e argumentações (Brasil, 2006). Ao dispor as Ciências da Natureza como área de estudos intenciona-se construir uma visão do conhecimento mais sistêmico: "[...] como área de estudos tem por base uma visão epistemológica que busca a ruptura com uma das visões que se tornou mais hegemônica dentro do ideal da modernidade. Desse ideal se concretizou, no sistema escolar, um projeto educacional de concepção positivista, exclusivamente disciplinar, parcelar, reducionista e enciclopedista de ciência, bem como uma supremacia das Ciências da Natureza sobre outras ciências e outros campos do conhecimento" (Brasil, 2006, p. 104).

O documento OCEM entende a necessidade de se articular, integrar e sistematizar fenômenos e teorias dentro de uma ciência, entre as várias ciências e áreas de conhecimento. Buscando essa intercomunicação, ele reconhece as orientações expressas nos documentos anteriores e ressalta a necessidade de integração entre as áreas do conhecimento: 


\begin{abstract}
- Construir uma visão sistematizada das diferentes linguagens e campos de estudo da Química, estabelecendo conexões entre diferentes temas e conteúdos;

- Adquirir compreensão do mundo, da qual a Química é parte integrante, por meio dos problemas que ela consegue resolver e dos fenômenos que podem ser descritos por seus conceitos e modelos;

- Articular o conhecimento químico e o de outras áreas no enfrentamento das situações-problema, como identificar e relacionar aspectos químicos, físicos e biológicos em estudos sobre a produção, destino e tratamento de lixo ou sobre a sua composição, poluição e tratamento das águas com aspectos sociais, econômicos e ambientais (Brasil, 2004, p. 237).
\end{abstract}

No ensino da Biologia, o documento incentiva a exploração de assuntos a partir da contextualização, sugerindo temas como, agronegócio, saúde pública, turismo ambiental, qualidade e de serviço ambiental etc. Uma prática que deve ser construída de acordo com o projeto pedagógico da escola, buscando uma integração que contemple uma abordagem simultânea de um mesmo assunto por diferentes disciplinas, respeitando as especificidades:

É importante observar que a interdisciplinaridade não acontece somente por força da lei ou pela vontade do professor, do diretor ou do coordenador pedagógico. $A$ interdisciplinaridade só é possível em um ambiente de colaboração entre os professores, o que exige conhecimento, confiança e entrosamento da equipe, e, ainda, tempo disponível para que isso aconteça. Daí a importância do projeto pedagógico da escola, que deve prever tempo, espaço e horários de atividades dos professores para que um programa de interdisciplinaridade possa ocorrer (Brasil, 2006, p. 37, grifo nosso).

No tocante ao ensino de Física incentiva-se a contextualização, um recurso didático que serve para problematizar a realidade vivida pelo educando, em que se busca elaborar uma representação do mundo para melhor compreendê-lo. Essa representação da realidade não é disciplinar, dada a complexidade do contexto, havendo a necessidade de se trabalhar de forma interdisciplinar:

\footnotetext{
Sabe-se que cada disciplina científica possui enfoques particulares, recortes dessa natureza que conduzem a uma organização de saberes padronizados passíveis de serem comunicados. A interdisciplinaridade não é a busca de uma unificação desses saberes, pois admitir isso seria negar aspectos históricos e epistemológicos da construção desse conhecimento e negar as características específicas, com objetos de estudo bem definidos, como a Física, a Química e a Biologia. Não basta uma justaposição de várias disciplinas (...).

O trabalho coletivo e a visão relacional da interdisciplinaridade estão mais próximos de aspectos metodológicos e pedagógicos (Brasil, 2006, pp. 51-52).
} 
O ensino de Matemática deve ter aplicação em outras áreas do conhecimento para a resolução de problemas práticos do cotidiano. Situações dessa natureza podem ser trabalhadas numa abordagem interdisciplinar, em que os educadores se articulam para proporcionar aos educandos a capacidade de integrar e relacionar os saberes das diferentes áreas do conhecimento (Brasil, 2006).

A base curricular nacional do conhecimento de Química, segundo o documento, pode ser estruturada para efeito didático em três pilares: transformações químicas, materiais e suas propriedades e modelos explicativos. As investigações centram-se nas propriedades, constituição e transformações dos materiais e substâncias. Esse tripé ajuda a compreender as bases em que está assentado o pensamento químico para esse nível de ensino. Entendendo que a finalidade da Educação Básica não se esgota aí, o documento incentiva assegurar ao educando uma formação indispensável ao exercício da cidadania. Então, a base curricular nacional deverá contemplar, também, a abordagem de temas sociais que propiciem ao aluno o desenvolvimento de atitudes e valores e a capacidade de tomar decisões. Essa abordagem temática visa a mediação dos saberes por meio de uma educação problematizadora, de caráter reflexivo e de desvelamento da realidade.

Assim, a contextualização expressa nos documentos norteadores almejam a concretização dos conteúdos curriculares na relação entre teoria e prática. Os conhecimentos constituídos devem ter o papel central de formação da cidadania pela reflexão crítica da situação existencial dos educandos. A contextualização da base comum se constituirá pela abordagem de temas sociais que possibilitem a discussão de aspectos sócio-científicos, os quais remetem-se às questões ambientais, econômicas, sociais, políticas, culturais e éticas:

Para compreender a energia em seu uso social, as considerações tecnológicas e econômicas não se limitam a nenhuma das disciplinas, tornando essencial um trabalho de caráter interdisciplinar.

Essa articulação interdisciplinar, promovida por um aprendizado com contexto, não deve ser vista como um produto suplementar a ser oferecido eventualmente se der tempo, porque sem ela o conhecimento desenvolvido pelo aluno estará fragmentado e será ineficaz. É nesse contexto que dá efetiva unidade à linguagem e conceitos comuns às várias disciplinas, seja a energia da célula, da Biologia, da reação, na Química, do movimento, na Física, seja no impacto ambiental das fontes de energia, em Geografia, a relação entre as energias disponíveis e as formas de produção, na História. Não basta, enfim, que energia tenha a mesma grafia, ou as mesmas unidades de medida, deve-se dar condições para compor e relacionar, de 
fato, as situações, os problemas e os conceitos, tratados de forma relativamente diferente nas diversas áreas e disciplinas.

Para isso, os professores precisam relacionar as nomenclaturas e os conceitos de que fazem uso com o uso feito nas demais disciplinas, construindo, com objetivos mais pedagógicos do que epistemológicos, uma cultura científica mais ampla. Isso implica, de certa forma, um conhecimento de cada uma das disciplinas também pelos professores das demais, pelo menos no nível do ensino médio, o que resulta em uma nova cultura escolar, mais verdadeira, pois se um conhecimento em nível médio de todas as disciplinas é o que se deseja para o aluno, seria pelo menos razoável promover esse conhecimento na escola em seu conjunto, especialmente entre os professores (Brasil, 2006, p. 121, grifo nosso).

Os professores devem necessariamente dialogar com as outras disciplinas, relacionar as nomenclaturas e os conceitos de que fazem uso, com o uso feito nas demais disciplinas, construindo com isso uma cultura científica mais ampla. Isso implica propiciar espaços de interação, resultando numa nova cultura escolar, mais verdadeira, ampla e significativa:

\begin{abstract}
A interdisciplinaridade supõe um projeto político-pedagógico de escola bem articulado com a parceria dos gestores, sendo essencial estabelecerem relações que envolvam saberes diversificados, os dos alunos e os das disciplinas, não como mera justaposição, propiciando um conhecimento do fenômeno na sua complexidade. Reafirma-se que, no âmbito da escola, é necessário proporcionar tempo para encontros sistemáticos de professores por áreas de estudo, que contribuam para avaliar ações disciplinares e interdisciplinares, bem como para projetar novas ações, o que potencializa práticas de trabalho coletivo sobre contextos vivenciais, ou temas sociais. Sem os encontros periódicos, tais práticas tendem a permanecer como episódios isolados, sem romper com a fragmentação e a linearidade da organização curricular (Brasil, 2006, p. 133, grifo nosso).
\end{abstract}

A interdisciplinaridade necessita do conhecimento específico dos participantes. Neste sentido, ela é pensada na perspectiva entre professores.

O documento OCEM busca explicitar os avanços presentes na LDB, PCNEM e PCN+. Ao fazê-lo, aponta ações decisivas marcadas pela efetiva participação dos professores na definição teórico-metodológica de implementação curricular. Essa participação dos professores não dispensa a leitura e o estudo dos PCNEM, PCN+, PCNEM e LDB, pois, esses documentos são necessários à formação docente por subsidiarem discussões e possibilitarem a participação nas (re)elaborações curriculares indispensáveis ao desenvolvimento do processo educacional.

Entende-se também, ser fundamental o estreitamento do diálogo e interação no âmbito das disciplinas/áreas. As escolas, ao manterem uma organização disciplinar, devem possibilitar um diálogo entre as disciplinas e áreas. Necessariamente é preciso se instituir e 
garantir espaços interativos de planejamento e acompanhamento coletivo da ação pedagógica.

Com relação à prática interdisciplinar, esta necessita da participação de cada uma das disciplinas pelos professores. A interdisciplinaridade é pensada na perspectiva entre professores, em que é incentivado o diálogo entre as disciplinas pelos participantes. Reafirma-se que a compreensão de reformas efetivas só acontece na viabilização real da articulação entre gestores, professores, estudantes e comunidades, em processos decisórios coletivos, que devem garantir autonomia e respeito à diversidade.

A mudança na prática docente depende da participação efetiva dos professores nas decisões a serem tomadas em sua área de ensino. Os professores precisam ser coresponsáveis das mudanças a serem implementadas. Ao mesmo tempo necessitam de formação contínua, a qual depende fundamentalmente de melhores condições de trabalho.

As propostas de trabalhos interdisciplinares, defendidas no documento, não devem ser entendidas como uma proposta suplementar ao currículo. A integração deve ser feita entre as disciplinas do currículo básico. O propósito visa romper com a cultura disciplinar, fragmentada e tributária do pensamento positivista.

Sobre como o trabalho interdisciplinar deve se desenvolver há uma certa divergência de natureza epistemológica entre os documentos: PCNEM de 1999, PCN+ de 2002 e OCEM de 2004 e 2006. Os primeiros incentivam uma integração entre as disciplinas pelo próprio professor. Já os últimos estimulam a interdisciplinaridade entre os professores da área, ou áreas do conhecimento.

Assim, observamos que os documentos oficiais convivem com diferentes conceitos de interdisciplinaridade, os quais podem ser resultado de diferentes ideologias de seus orientadores e elaboradores. Justifica-se, assim, conhecermos as concepções de alguns desses elaboradores dos documentos oficiais. 


\section{Capítulo 4 - Metodologia}

O nosso trabalho assume o enfoque de uma pesquisa qualitativa, pois o que nos interessa é a compreensão da concepção de práticas integralizadoras, mais especificamente a concepção de interdisciplinaridade de alguns professores. Buscamos intensamente o significado dentro do contexto, os entendimentos e justificativas dos participantes, conforme Moreira "[...] a pesquisa qualitativa se preocupa mais com a compreensão do fenômeno social, segundo a perspectiva dos atores, através da participação na vida desses atores [...]" (1990, p. 29). Não tomamos o procedimento como um fim, muito menos, a quantificação dos dados como fim em si mesmo.

Realizamos dezesseis entrevistas, sendo oito com professores que também são pesquisadores da área de Ensino de Ciências, seis dos quais foram consultores do MEC na elaboração dos documentos oficiais. Das outras oito entrevistas, sete foram com professores do Ensino Médio em serviço, sendo que destes, três eram mestrandos em Ensino de Ciências e quatro eram professores pertencentes à Diretoria de Ensino-Região de Tupã-SP. Entrevistamos também um supervisor da mesma D.E. mencionada.

A pesquisa está baseada no tipo de entrevista semi-estruturada, buscando deixar o entrevistado o mais livre possível (Mayring, 2002). Na oportunidade procuramos conduzir as entrevistas como uma "boa conversa". Para tanto, sempre que possível, buscamos previamente conhecer o que o entrevistado já havia publicado sobre o assunto; no caso dos alunos da pós-graduação, procuramos conhecer um pouco sobre os seus trabalhos de pesquisa e a vivência na pós-graduação. Com relação aos professores do Ensino Médio da Diretoria de Ensino, mantivemos contato, nos seus respectivos ambientes de trabalho. O uso desse instrumento de pesquisa teve a pretensão de nos colocar no contexto prático/cognitivo dos entrevistados para atuarmos nesse espaço dialógico com mais liberdade.

Durante as entrevistas tentamos dar a maior liberdade de expressão aos entrevistados, pois no decorrer do diálogo, os pontos que considerávamos importantes à nossa pesquisa iriam se explicitar de maneira natural. Entretanto, tomamos o cuidado de voltarmos, ainda que discretamente, em alguns pontos, que julgamos não estar 
suficientemente claros. Acreditamos que essa estratégia facilitou o procedimento a um minucioso exame dos elementos que estão no contexto; indo com certa "leveza" nos pontos importantes que necessitávamos amealhar na pesquisa. Assim, entendemos, que a entrevista semi-estruturada é uma forma de coleta de dados que supõe uma conversação continuada entre o pesquisador e o entrevistado, com certo direcionamento de acordo com os interesses da pesquisa (Apêndice 1).

\subsection{Participantes da pesquisa: nosso público}

O público da nossa pesquisa se constitui de oito professores universitários que trabalham tanto na formação inicial e contínua de professores, como atuam na pesquisa em Ensino de Ciências. Desses professores analisados, quatro foram consultores dos Parâmetros Curriculares Nacionais (PCNEM e PCN+) ${ }^{12}$ e dois foram consultores dos documentos Orientações Curriculares para o Ensino Médio (OCEM de 2004 e 2006).

Entrevistamos, também, quatro professores do Ensino Médio da Diretoria de Ensino da Região de Tupã-SP, os quais trabalharam nos anos de 2003 e 2004 com a proposta de projetos de trabalhos interdisciplinares e o supervisor de ensino dessa Diretoria, responsável pela implementação da proposta. Ouvimos ainda, três alunos da pós-graduação no Ensino de Ciências - Modalidade Química da Universidade de São Paulo sobre essa proposta de currículo integrado, visto que alguns deles atuam diretamente no Ensino Médio e futuramente atuarão na formação de professores.

\section{Professores/pesquisadores e formadores}

$\mathrm{P}_{1}$ e $\mathrm{P}_{2}$ atuam como professores de química no ensino superior. O primeiro mantém interesse de pesquisa focado em conteúdos curriculares de química, ensino-aprendizagem de química, formação contínua de professores. O segundo trabalha com pesquisa no ensino de química, especificamente com a formação contínua de professores de ciências naturais, no desenvolvimento de currículo na área de ciências e suas tecnologias.

$\mathrm{P}_{3}, \mathrm{P}_{4}$ e $\mathrm{P}_{6}$ são professores de física no nível superior. $\mathrm{P}_{3}$ se dedica à formação de professores e à orientação curricular para a educação básica. Dirige, também, atividades de

\footnotetext{
${ }^{12}$ A fim de manter a privacidade dos nossos entrevistados, usamos siglas: $\mathrm{P}_{1} ; \mathrm{P}_{2 \ldots} \mathrm{P}_{16}$, e nomes fictícios relacionados às suas metodologias de trabalho quando à elas nos referirmos. Esses nomes estão entre aspas $\mathrm{e}$ sublinhados. Esse procedimento foi adotado em todas entervistas.
} 
extensão universitária e de pesquisas sobre ensino superior. $\mathrm{P}_{4}$ tem interesse de pesquisa voltado para o ensino de física, ciência cognitiva, história da ciência e interdisciplinaridade. $\mathrm{P}_{6}$ desenvolve pesquisa na área de educação, com ênfase em ensino de física.

$\mathrm{P}_{5}$ é professor universitário, atuando na área de educação, com ênfase em fundamentos da educação.

$\mathrm{P}_{7}$ exerce atividades de docência no Ensino de Ciências, com interesse de pesquisa em currículo voltado para a concepção de disciplina sócio-histórica.

$\mathrm{P}_{8}$ atua no desenvolvimento de currículo escolar em ciências naturais, na formação inicial e contínua de professores de ciências.

\section{Alunos da pós-graduação no Ensino de Ciências-modalidade Química}

Com relação aos alunos da pós-graduação ${ }^{13}$ procuramos ouvir os que já tinham certa vivência neste nível de ensino, procurando evidenciar o como e o quanto as disciplinas do mestrado e o convívio acadêmico exerceram de mudança nas suas concepções de currículo integrado. Assim, optamos por alunos que haviam qualificado $\left(\mathrm{P}_{10}\right)$ ou próximo da qualificação $\left(\mathrm{P}_{9}\right)$, ou que já haviam terminado as disciplinas obrigatórias $\left(\mathrm{P}_{11}\right)$.

$\mathrm{P}_{9}$ tem lecionado na escola pública há dez anos e lecionou na particular por três anos. Possui formação em licenciatura em química pela Fundação Instituto de Ensino de Osasco-FIEO, atualmente UNIFIEO. Atualmente faz pós-graduação, nível mestrado no Ensino de Ciências - modalidade Química na Universidade de São Paulo-USP, desde 2004.

$\mathrm{P}_{10}$ atua na rede particular há oito anos. É bacharel em química pela Universidade Mackenzie, com pedagogia em administração escolar pela Universidade de São Paulo. Fez mestrado em Ensino de Ciências-modalidade Química pela Universidade de São PauloUSP, tendo defendido sua dissertação em 2007.

$\mathrm{P}_{11}$ lecionou por dois anos na escola pública e um ano na particular. É licenciado em química pela Universidade Federal de Juiz de Fora-UFJF. Atualmente cursa mestrado no Ensino de Ciências-modalidade Química, com início em 2005.

\section{Professores do Ensino Médio da Diretoria de Ensino-Região de Tupã-SP}

\footnotetext{
${ }^{13}$ Os dados foram extraídos das entrevistas concedidas.
} 
A Diretoria de Ensino-Região de Tupã-SP foi constituída inicialmente com a denominação de $\operatorname{DESN}^{14}$ (Delegacia de Ensino Secundária e Normal), atendendo aos cursos: ginásio, científico, clássico e normal. Essa delegacia passou a coexistir com a DEB (Delegacia de Educação Básica-antigo primário). Em janeiro de 1976 ocorreu a sua fusão num único órgão, denominado D.E. (Delegacia de Ensino), sendo jurisdicionada à DRE de Marília (Delegacia Regional de Ensino). A partir de 23 de março de 1994, passou a denominar-se "Prof. Katsumi Nakayama"15.

Na gestão do governo Mário Covas, houve uma reestruturação da rede de ensino, havendo o fechamento das DREs. Nessa nova organização, a D.E. de Tupã passou a ser denominada Diretoria de Ensino-Região de Tupã ${ }^{16}$, tornando-se a instância de representação da SEE (Secretara de Estado de Educação), abrangendo os municípios de Tupã, Bastos, Iacri, Herculândia, Quintana, Arco Íris, João Ramalho, Parapuã, Quatá, Queirós, Rancharia, Ajicê e Rinópolis, denominando-se então, Diretoria de Ensino-Região de Tupã.

Para as nossas entrevistas, selecionamos alguns professores das escolas jurisdicionadas a essa Diretoria.

$\mathrm{O}$ professor $\mathrm{P}_{12}$ leciona química na escola pública EE de Parapuã, na cidade de Parapuã-SP ${ }^{17}$, exercendo atividade no magistério há trinta anos e trabalhou na escola particular por um período de três anos. Formado em ciências com complementação no ensino de química na Faculdade de Ciências, Letras e Educação de Presidente Prudente APEC, atualmente conhecida como Universidade do Oeste Paulista - UNOESTE, que se situa a cento e trinta quilômetros da cidade Tupã-SP.

\footnotetext{
${ }^{14}$ DECRETO N. 52.707, de 11 de março de 1971. Cria a Delegacia de Ensino Secundário e Normal e das Providências correlatas. Roberto Costa de Abreu Sodré, governador de São Paulo, no uso de suas atribuições, e considerando a expansão da rede de ensino médio decorrente de criação e instalação de ginásio e colégios. Considerando a necessidade de se propiciar aos novos estabelecimentos a imprescindível assistência técnica e administrativa, decreta: Artigo $1^{\circ}$ - Ficam criadas 03 (três) Delegacias de Ensino Secundário e Normal, localizadas nas cidades de Mogi das Cruzes, Lorena e Tupã, respectivamente nas DRE de Grande São Paulo, Vale do Paraíba e Bauru.

${ }^{15}$ LEI No 8.632, de 23 de março de 1994 (Projeto de lei no 796/93, do deputado Dalla Pria). Confere a denominação à Delegacia de Ensino de Tupã.

${ }^{16}$ DECRETO No 43.948 de 09 de abril de 1999. Artigo $1^{\circ}$ - As delegacias de Ensino da Secretaria de Educação, criadas pelo Decreto ${ }^{\circ} 7.510$, de 09 de janeiro de 1976, que integram os anexos I e II do Decreto $\mathrm{n}^{\circ} 39.902$ de $1^{\circ}$ de janeiro de 1995 , com alterações posteriores, passam a denominar-se diretoria de ensino.

${ }^{17}$ Aproximadamente a trinta e cinco quilômetros de Tupã-SP.
} 
$\mathrm{P}_{13}$ atua como professor de geografia e coordenador na EE Tsuya Ohno Kimura, na cidade de Bastos-SP ${ }^{18}$. É bacharel e licenciado em geografia pela Universidade Estadual de Londrina-UEL, lecionando no ensino público há dezessete anos e há oito anos em escola particular.

$\mathrm{P}_{14}$ leciona química na escola pública EE Aristides Rodrigues Simões há vinte e quatro anos, na cidade de Herculândia-SP ${ }^{19}$. Possui licenciatura no Ensino de Ciências e complementação no ensino de química, na mesma instituição de $\mathrm{P}_{12}$.

$\mathrm{P}_{15}$ leciona na mesma unidade escolar de $\mathrm{P}_{14}$, atuando no ensino público desde 1981, sendo formado em licenciatura e bacharelado em Química pela Faculdade Auxiliadora de Lins-FAL.

$\mathrm{P}_{16}$ é supervisor de ensino da Diretoria de Ensino-Região de Tupã-SP, formado em Letras, com trinta e quatro anos de atuação como professor de Ensino Médio e Superior e vinte anos de supervisão, sendo responsável pela proposta de trabalhos por projetos interdisciplinares no Ensino Médio na D.E.- Região de Tupã, nos anos de 2003 e 2004.

A justificativa para a escolha dos entrevistados refere-se ao fato de que esses professores estavam exercendo suas atividades, nos anos de 2003 e 2004, quando da implantação da proposta de trabalho com projetos interdisciplinares, que deveriam ser implantados em todas as três séries do Ensino Médio da Diretoria de Ensino de Tupã. Essa proposta começou gradativamente com as primeiras séries, no ano de 2003, estendendo-se para as segundas e terceiras séries, no ano de 2004. Consideramos, também, o tempo de atuação desses professores no ensino da rede pública e qual o efeito desses anos de atuação com uma prática consolidada pudesse exercer nessa proposta de trabalho interdisciplinar.

\subsection{Análise dos dados}

\section{Mapas Cognitivos}

Foram realizados ao todo dezesseis entrevistas com aproximadamente 45 minutos de duração cada uma, totalizando quase dez horas de gravações em áudio. Essas entrevistas foram todas transcritas e a seguir foram selecionadas as unidades de análise. O critério de seleção dessas unidades de análise foi o de conseguir captar as concepções principais dos

\footnotetext{
${ }^{18}$ Vinte e dois quilômetros de Tupã-SP.

${ }^{19}$ Dezessete quilômetros de Tupã-SP.
} 
entrevistados, tendo por foco a interdisciplinaridade e as idéias sobre os conceitos relacionados, bem como as falas que revelavam como esses professores fazem a interdisciplinaridade na prática da sala de aula, quais os problemas etc.

Para uma análise e sistematização dos dados presentes nas entrevistas, optamos pelo uso de mapas cognitivos, como instrumento de análise qualitativa (Llinares, 1992). Mapas cognitivos representam a descrição da imagem mental de uma pessoa a respeito de um objeto, ou situação. Estes mapas relacionam de forma parcialmente hierarquizada e não linear as "unidades de análise", buscando relacioná-las sistematicamente (Ruiz et al., 2005; 1996; Mellado, Silva e Ruiz, 2004).

Os mapas cognitivos permitem uma visão global e não fragmentada das concepções dos nossos entrevistados. Ao optar por esse instrumento de análise, nosso propósito foi o de representar e de certa forma extrair a "essência do pensamento" proposto no texto, buscando conexões e conservando os conceitos de forma esquemática. O mapa cognitivo tende a uma estrutura mais psicológica, formando uma representação idiossincrática da pessoa (Llinares, 1992; Ruiz et al., 2005). O mapa cognitivo é um instrumento útil para auxiliar na elaboração e estruturação de pesquisas qualitativas. Por meio dele é possível entender como os diferentes aspectos do pensamento se inter-relacionam, revelando como o processo de construção das idéias pode se constituir numa simples reflexão da situação problemática, ou envolver a compreensão de uma situação bastante complexa. Portanto, eles podem ser empregados para representar diferentes concepções de pensamento. Seu uso tem sido bastante intensivo, na psicologia e no ensino, pois nestes contextos são usados como sistemas para explicitar descrições da "imagem mental" de uma pessoa a respeito de suas concepções. Assim, esses mapas têm ajudado na construção das representações, e de alguma forma, sistematizado as idéias principais dos entrevistados (Llinares, 1992; Bermejo, González e Mellado, 2004; Mellado, Silva e Ruiz, 2004; Ruiz et al., 2005).

O mapeamento cognitivo se fundamenta na Teoria de Constructos Pessoais (Ackermann, Colin e Cropper, 1993; Araújo e Riedg, 2003, p.147), que tem três pressupostos norteadores:

- O homem está sempre buscando explicar seu mundo;

- Ele estabelece o sentido do mundo por meio de contrastes e similaridades;

- E ao buscar compreender o significado de seu mundo, o homem organiza seu sistema de constructos ${ }^{20}$.

\footnotetext{
${ }^{20}$ Representação de uma idéia, uma informação.
} 
As idéias de um indivíduo sobre determinada situação apresentam-se interligadas, e de uma certa forma com valores diferenciados, formando um sistema de constructo próprio. Este sistema está relacionado diretamente com os valores e escolhas diante dos acontecimentos. Entender o sistema de constructos de determinadas pessoas é, por assim dizer, compreender o sentido e significado de como ela concebe o mundo diante dos acontecimentos. Neste sentido, os mapas cognitivos são um esforço para isolar e representar os construtos de uma pessoa e dispô-los de forma organizada e compreensível, a partir da nossa interpretação ${ }^{21}$. Essa disposição tem o objetivo de poder realizar comparações, no nosso caso, das concepções dos diferentes entrevistados sobre interdisciplinaridade.

Assim, um mapa cognitivo assume a forma de uma rede de frases, "unidades de análise" ligadas por conectores, na qual, a frase captura e reflete diretamente a maneira como um indivíduo expressa uma idéia. Para Llinares “(...) os mapas cognitivos são um modo de organizar os dados que se possui, portanto uma forma de facilitar as reflexões que podem levar à generalização de uma teoria que explique os dados obtidos” (Llinares, 1992, p. 77).

A elaboração dos mapas cognitivos não segue uma ordem rígida; sendo impossível estabelecer regras para a sua execução, pois não se trata de uma ciência exata, mas de uma forma parcialmente hierarquizada de se dispor as unidades de informação, permitindo uma visão global e não fragmentada das concepções dos entrevistados (Bermejo, González e Mellado, 2004; Mellado, Silva e Ruiz, 2004).

Com intuito de sinalizar algumas etapas, relacionamos abaixo diretrizes de aspectos gerais para a sua elaboração, tendo-nos baseado nos trabalhos de Ackermann, Colin e Cropper, 1993; Llinares, 1992:

\footnotetext{
- Decompor o relato em sentenças que irão constituir as unidades de análise, as quais constituem os conteúdos essenciais;

- Identificar as relações do texto que podem caracterizar os níveis de microestrutura textual em que estão presentes as proposições individuais e algumas de suas relações, e o de macro-estrutura, em que se caracteriza o texto como um todo; - Manter nos conceitos a linguagem usada pelo entrevistado, ao máximo;

- Fazer, quando necessário, pequenas modificações, sem perder a propriedade da fala do entrevistado.
}

\footnotetext{
${ }^{21}$ A seleção das "unidades de análise" na elaboração do mapa cognitivo está ligada ao interesse do olhar do pesquisador. Esse viés, certamente acaba por determinar um recorte sobre o objeto pesquisado.
} 
Por fim, entendemos que os mapas cognitivos não são receitas que permitirão ao usuário padronizar modelos, pois não há um mapa definitivo.

A partir das diretrizes supra-mencionadas, apresentamos o processo de construção do mapa de $\mathrm{P}_{4}$, a partir da entrevista, e em seguida os trechos das entrevistas que geraram as unidades de análise, que estão numeradas no mapa e correspondem à mesma numeração na entrevista transcrita (Apêndice 2). As unidades de análise têm como objetivo facilitar o entendimento durante a leitura e análise do mapa, bem como situar as unidades selecionadas nas entrevistas, conforme figura 4A. Esse mesmo procedimento foi realizado para os demais mapas elaborados.

Trecho da entrevista de $\mathrm{P}_{4}$ :

$\mathrm{P}_{4}$ - Não, não eu acho que o aluno não faz isso sozinho, precisa do professor para fazer, e às vezes os professores não fazem, eu acho que o professor não faz, a mesma coisa é fazer a conexão com o cotidiano, quer dizer, não adianta querer que o aluno perceba a conexão da ciência com o cotidiano se os professores não fizeram as suas e dão como exemplo, essa é uma forma de se abordar a interdisciplinaridade, por exemplo, como eu vou fazer um recorte agora interdisciplinar, [busca construir conexões com conteúdos que (11) dizem respeito a várias disciplinas,] ou a duas delas, conteúdos na minha pandisciplinaridade, faço um recorte na escolha de um conjunto de conteúdos que tem uma seqüência, que pode ter diversas seqüências, mas eu estou supondo uma, mas que envolve, por exemplo, no caso em que as vezes pra mim é mais fácil pensar na biologia e na física, então, você pensa em dinâmica de populações, quando você está falando em dinâmica de populações a modelagem que a física faz dos problemas biológicos da dinâmica, implica que o sujeito tem que compreender a biologia, porque senão, porque perde nuances que são da biologia que não dizem respeito a física, se ele quer modelar aquilo ele tem que aprender biologia, senão ele vai falar do rato $(\mathrm{R})$ da raposa $(\mathrm{X})$ etc e tal, quer dizer, ele tem que se interar daquele ponto dentro da biologia, quer dizer, que sentido tem aquele conteúdo dentro da biologia, se não ele simplesmente pega um problema, isola aquele problema, ao invés de chamar raposa e coelhos, ele chama de $(\mathrm{R})$ de $(\mathrm{C})$ e cria uma dinâmica entre eles e tal e você cria um "modelinho" que pode ser aplicado a biologia ou não. Então, a pergunta é se eu quero ensinar ao sujeito ao usar física a usar instrumento da física dentro da biologia a gente precisa aprender biologia também, esse ponto de vista pra mim está mais claro. E isso não significa botar um professor de biologia e um de física dentro da sala de aula, isso não significa isso, porque as conexões, é isso o que eu estou falando da mesma forma do cotidiano, o professor tem intimidade [com as conexões implica ele dominar elas, (12) além do conteúdo da física], implica fazer essas ligações, eu preciso dominar o cotidiano, eu preciso os fenômenos do cotidiano com os instrumentos da física e ver a relação entre essas duas coisas pra poder falar com o meu estudante, a mesma coisa é a biologia pra mim, senão ele vai ter o problema de física como outro qualquer, cujo mote é falar do, da, eu não chamo isso de interdisciplinaridade. 


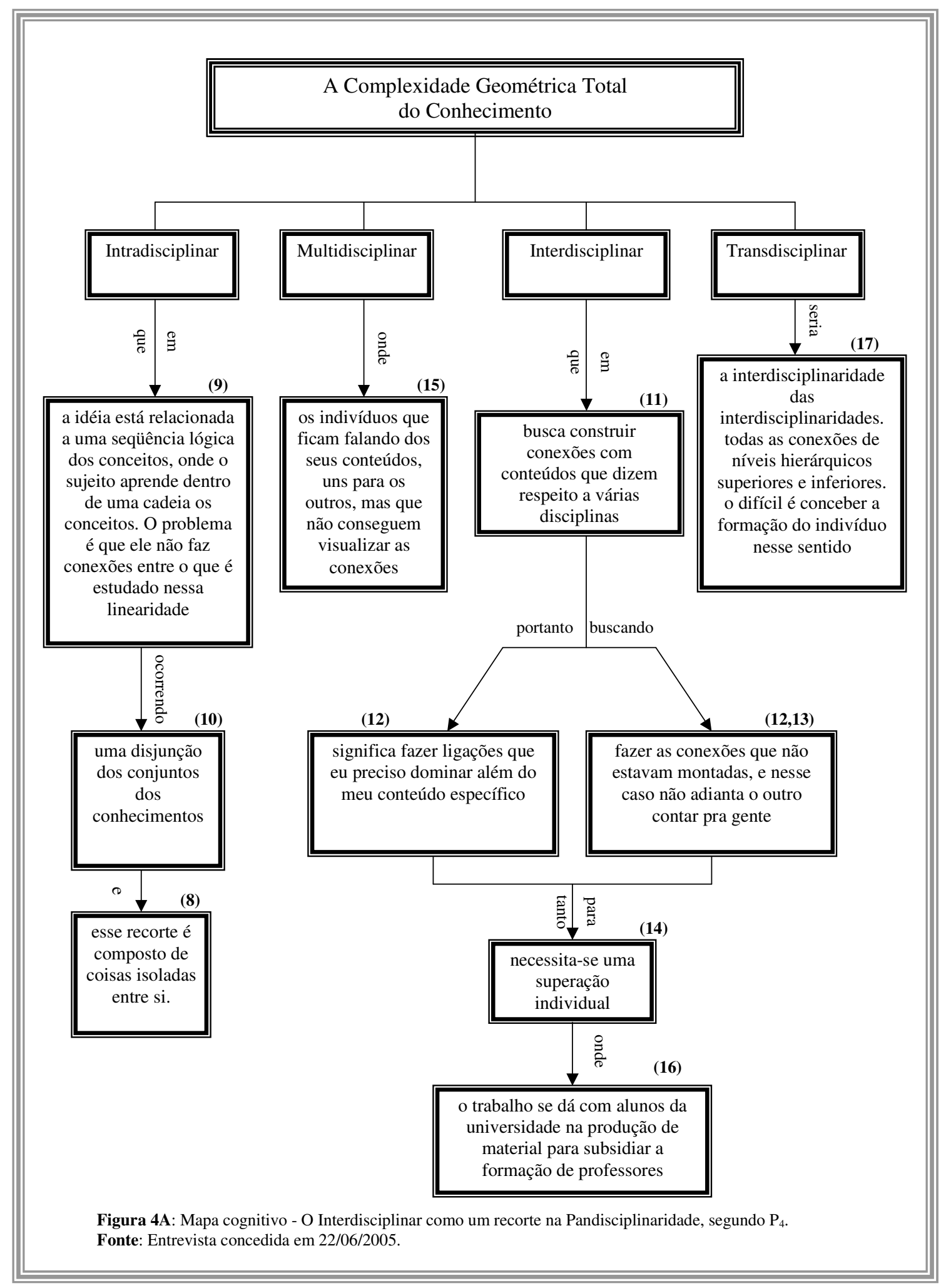




\section{Capítulo 5 - Resultados e Discussão}

\subsection{Resultados referentes aos professores/pesquisadores}

As entrevistas transcritas dos professores $\mathrm{P}_{1}$ a $\mathrm{P}_{16}$ estão integralmente apresentadas no apêndice 2. Nelas estão mostradas também as unidades de análise selecionadas. Os números que aparecem nas unidades de análise são os correspondentes nos mapas que iremos apresentar na seqüência.

Na figura 1, o mapa cognitivo corresponde ao professor $\mathrm{P}_{1}$.

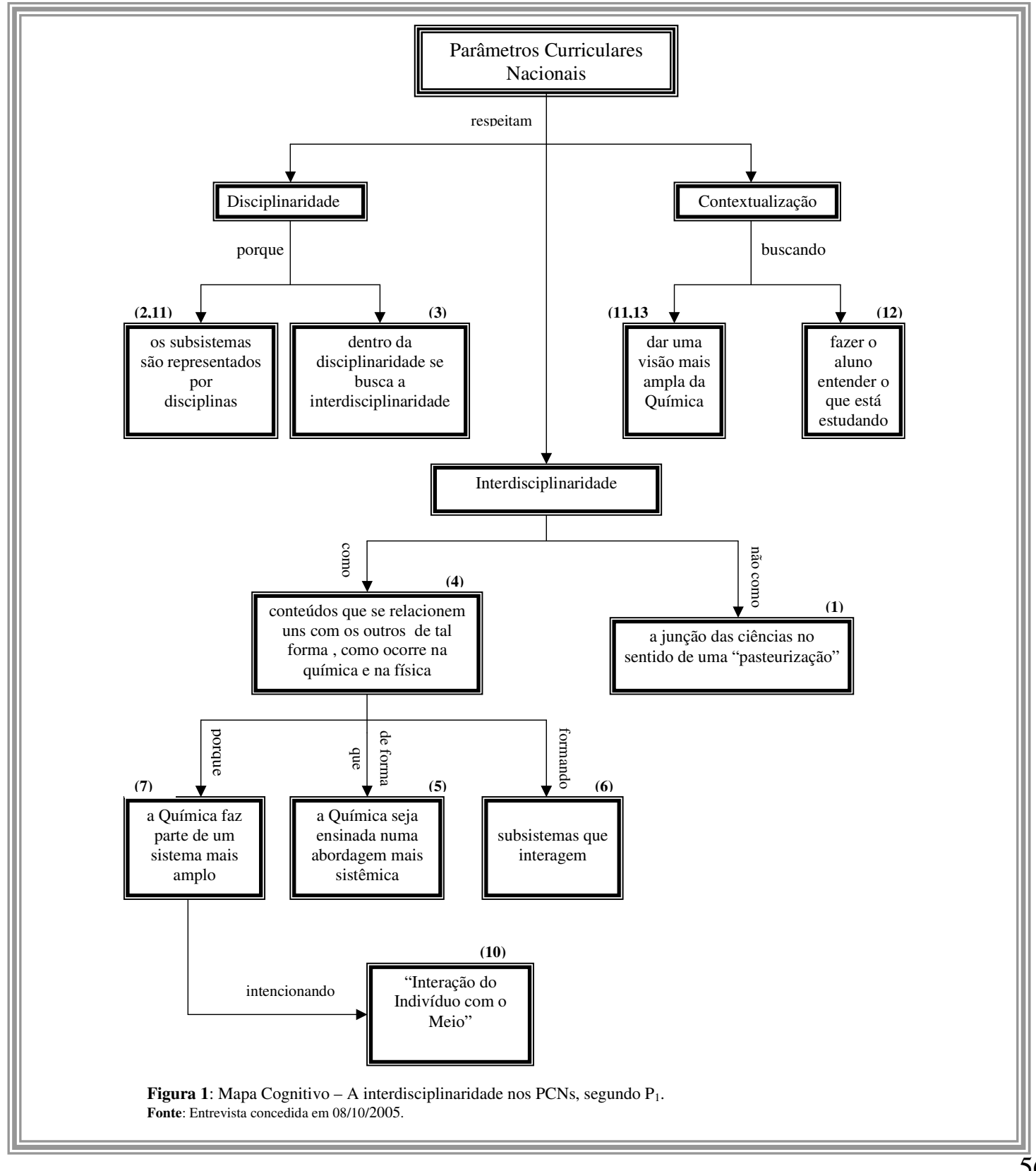


Nele aparece uma interpretação sobre a idéia de interdisciplinaridade que é colocada nos Parâmetros Curriculares Nacionais (PCNEMs) e que tentaremos explicitar aqui. De acordo com $\mathrm{P}_{1}$, os PCNEMs respeitam a disciplinaridade, buscando uma relação entre as disciplinas, através da interdisciplinaridade e consideram, ao mesmo tempo, o contexto no qual a disciplina está inserida. A idéia é mostrar que a química faz parte de um sistema mais amplo, permitindo que o aluno entenda o que está estudando; despertando-o para uma relação de harmonia entre ele e o meio em que está inserido. Em relação às demais práticas integradoras, $\mathrm{P}_{1}$ destaca três modalidades de ensino: multidisciplinar, interdisciplinar $\mathrm{e}$ transdisciplinar (figura 1A).

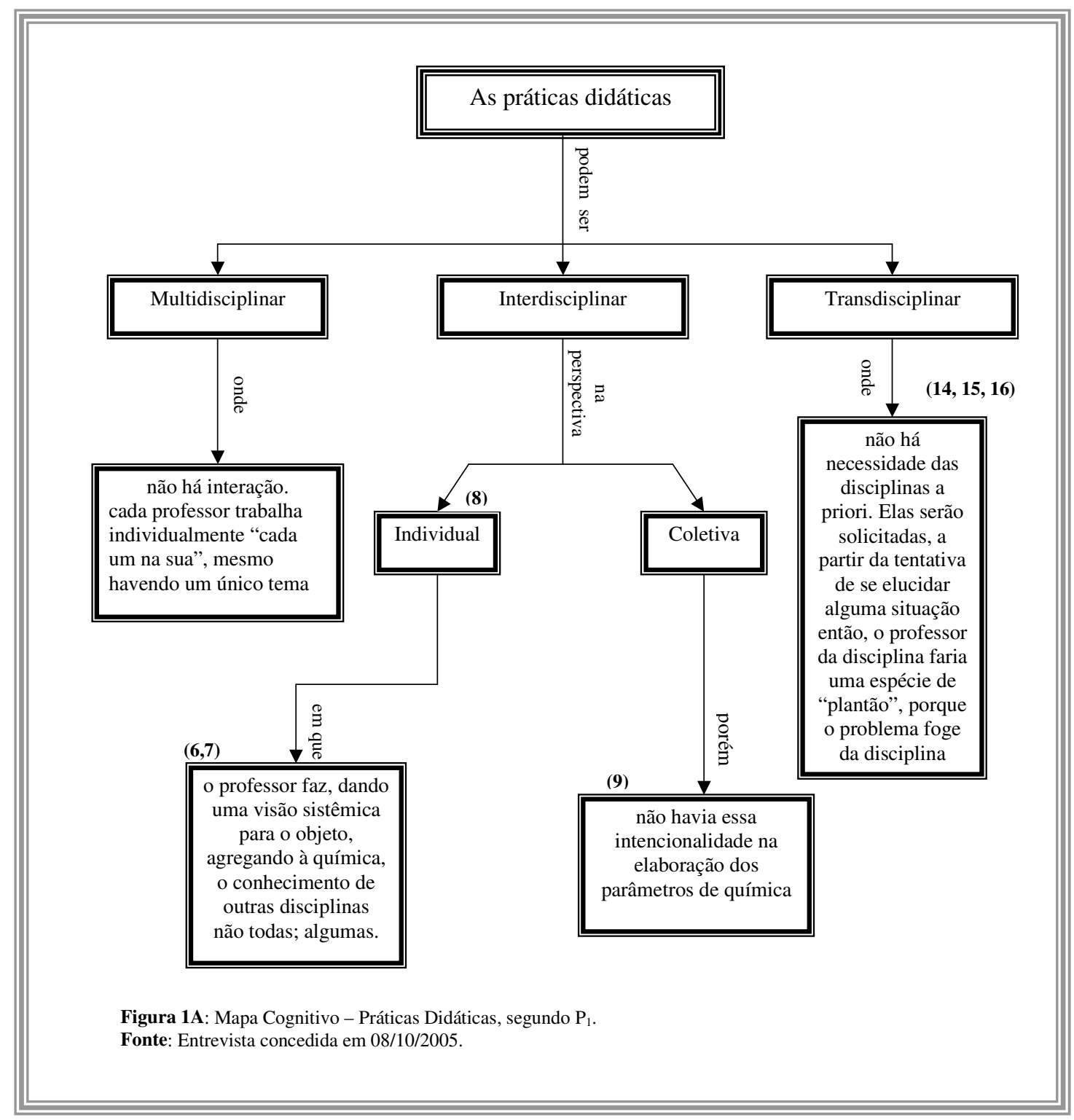


$\mathrm{Na}$ primeira, não ocorre interação entre os professores, cada um desenvolve a prática isoladamente, ainda que haja um tema comum. Na segunda, o próprio professor faz algumas superações, avançando nos conteúdos de outras disciplinas, agregando a química a elas. A intencionalidade é a de dar uma visão sistêmica ao objeto que se busca compreender. Entretanto, ao se referir à interdisciplinaridade coletiva por um grupo de professores, faz questão de esclarecer que essa prática não era intencionada nos PCNEMs, quando da sua elaboração. Finalmente, na questão da transdisciplinaridade, ressalta que a escola não tem necessidade de organizar as matrizes disciplinares a priori, pois as disciplinas tendem a se constituir, a partir de uma situação-problema.

$\mathrm{P}_{2}$ se refere à educação básica entendida nos documentos oficiais como áreas de conhecimento (figura 2).

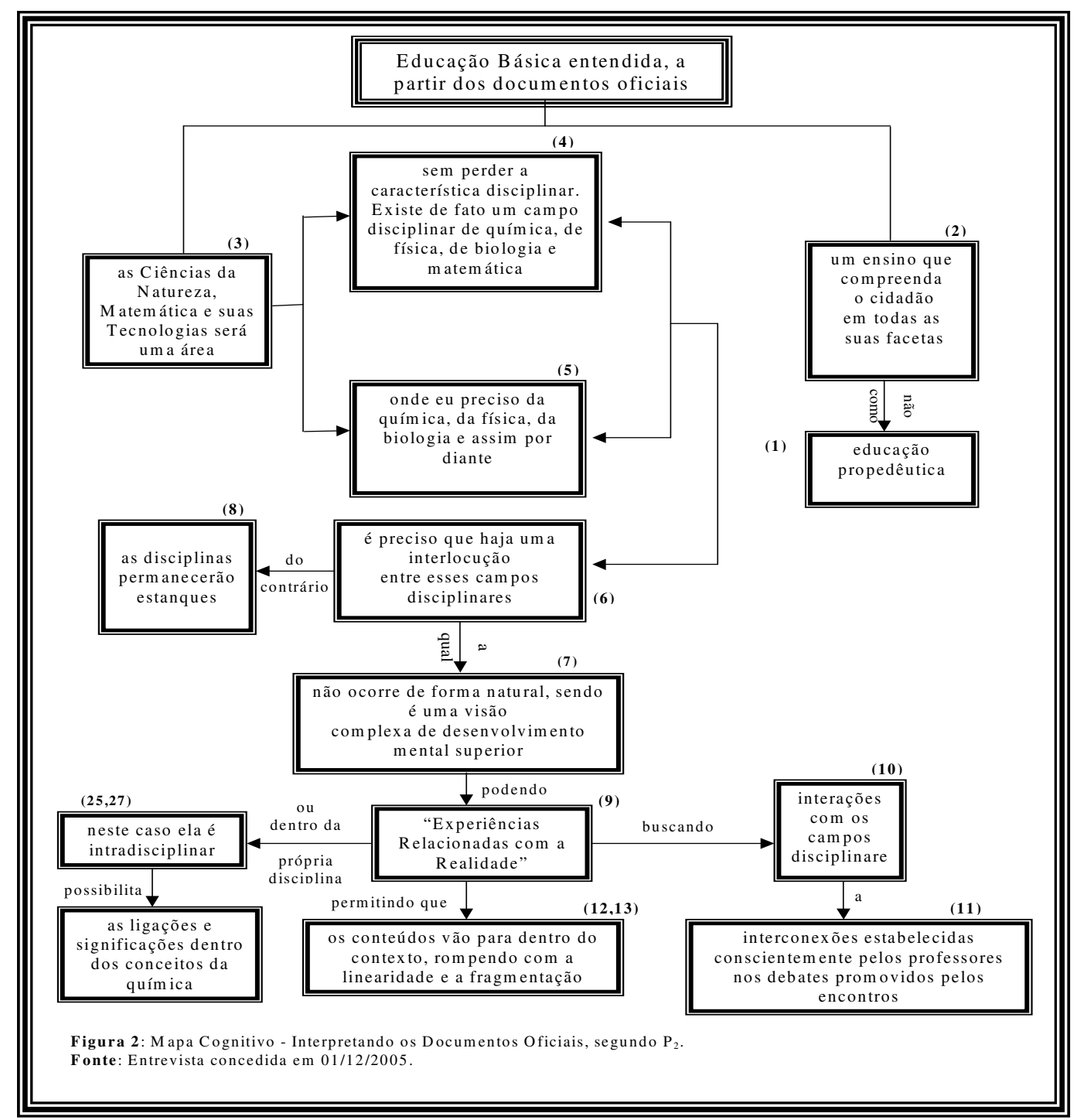


Segundo $\mathrm{P}_{2}$, na área de Ciências da Natureza Matemática e suas Tecnologias proposta pelo PCNEM; as disciplinas mantêm uma interlocução com as demais, sem perder, contudo a sua natureza disciplinar.

O diálogo entre as disciplinas é necessário para que não haja um ensino fragmentado, sem sentido, como um fim em si mesmo (figura 2A).

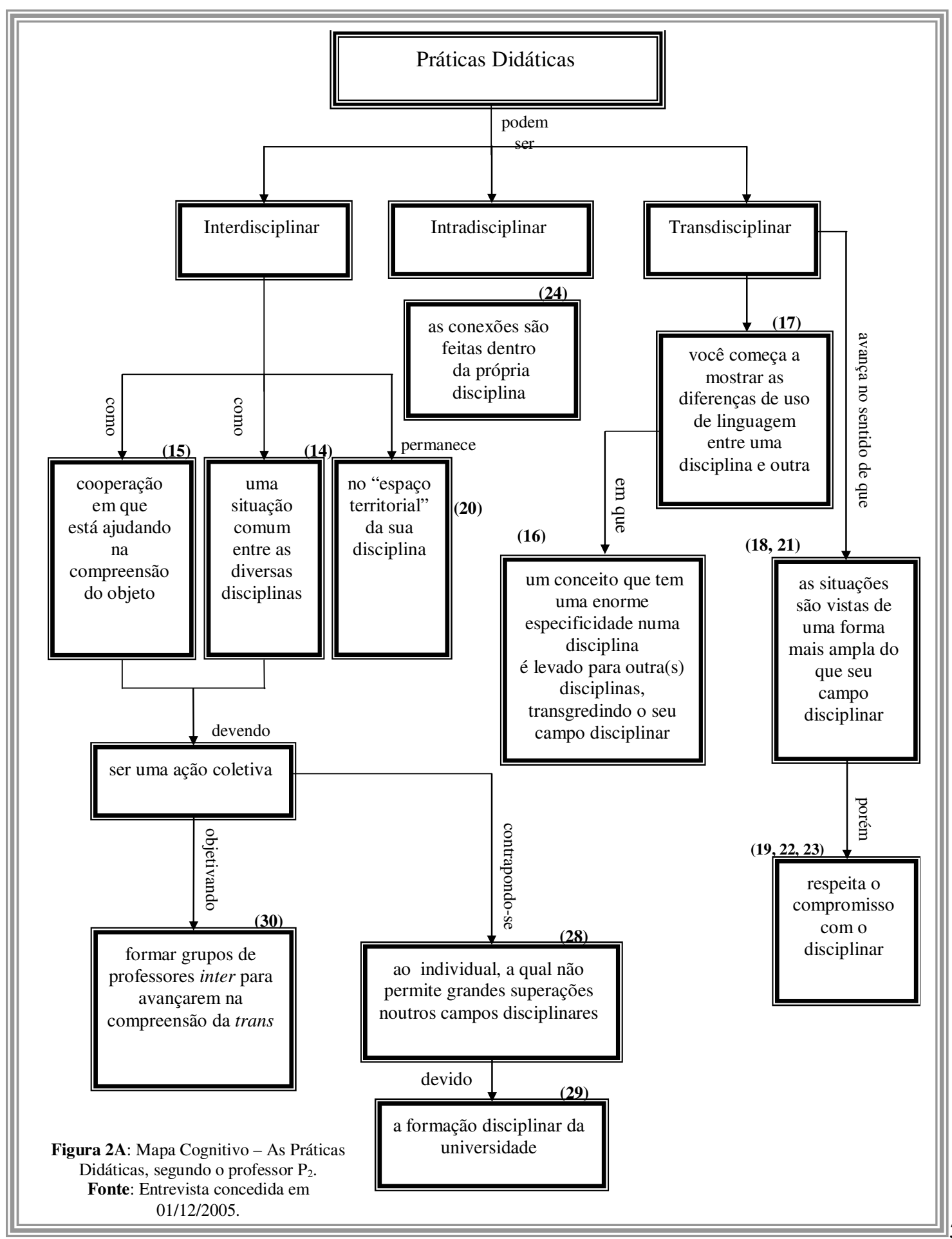


$\mathrm{P}_{2}$ sugere um ensino que compreenda o cidadão em suas diversas facetas, uma educação capaz de fazer interlocuções entre os diversos campos disciplinares com propostas que se aproximem da realidade. Ressalta ainda, que essas interconexões representam uma visão de complexidade superior, construída pelos campos disciplinares diferentes, ou dentro da própria disciplina de química, devendo ser desenvolvidas conscientemente pelos professores.

A concepção de intradisciplinaridade para $\mathrm{P}_{2}$ está posta nas conexões feitas pelos conceitos da própria disciplina.

Já na interdisciplinaridade existe uma cooperação entre as disciplinas na compreensão do objeto considerado, porém, ressalva que, as disciplinas fazem questão de resguardar seus limites (“territorialidades”), menção análoga à de Edgar Morin ao fazer analogia à ONU (Organização das Nações Unidas), onde muitos países se reúnem, cada qual para defender seus próprios interesses. No entender de $\mathrm{P}_{2}$, a interdisciplinaridade é um esforço que deve ser construído pelo grupo. Admite que algumas superações podem ser feitas individualmente, mas nada de grande expressão, devido à formação disciplinar do professor.

Para $\mathrm{P}_{2}$ o mote é a transdisciplinaridade, porque ela avança além das "vaidades" disciplinares, possibilitando que um conceito específico de uma dada disciplina vá, além muros, sendo adotado por outras, produzindo situações de estudo enriquecedoras. Entretanto, destaca que essas transgressões respeitam sempre o compromisso com a disciplinaridade.

Para $\mathrm{P}_{3}$, conforme destacado na figura 3, a pesquisa e o ensino, respeitando as especificidades, não apresentam nítidas demarcações ou fronteiras, pois as interações são próprias do mundo, o qual não está posto de forma fragmentada e insistir nessas demarcações é uma distorção que acaba por "mutilar" o objeto de estudo ou de pesquisa. Nesse sentido, as práticas tendem naturalmente à interdisciplinaridade e esse fazer pode se dar com a própria disciplina, construindo aberturas para outras. As "Atividades de Investigação do Meio", desenvolvidas nos seus cursos, são exemplos contundentes. 


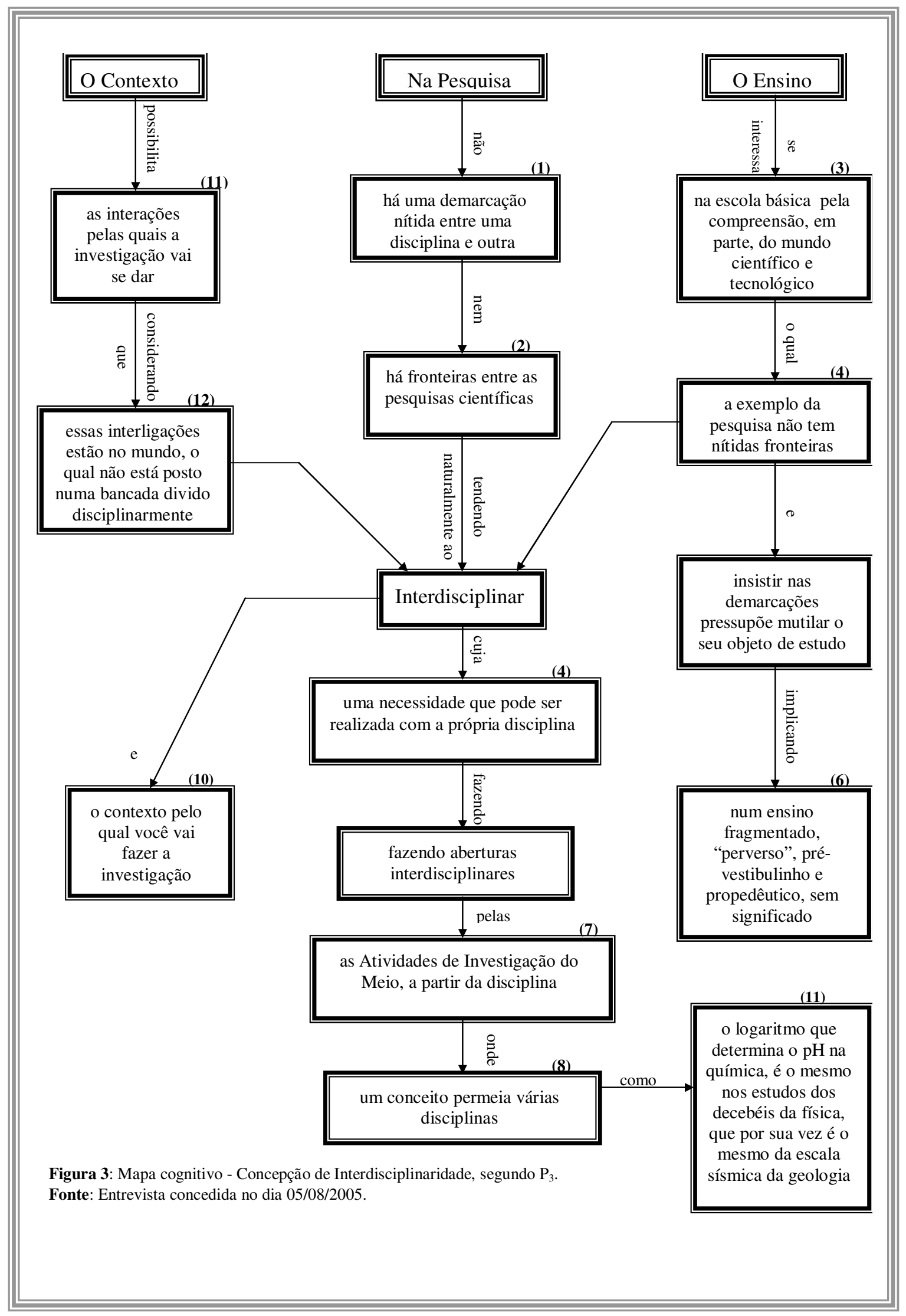


$\mathrm{P}_{4}$ destaca que a seleção e organização dos conteúdos devem necessariamente estar vinculados a critérios ontológicos, epistemológicos e axiológicos (figura 4).

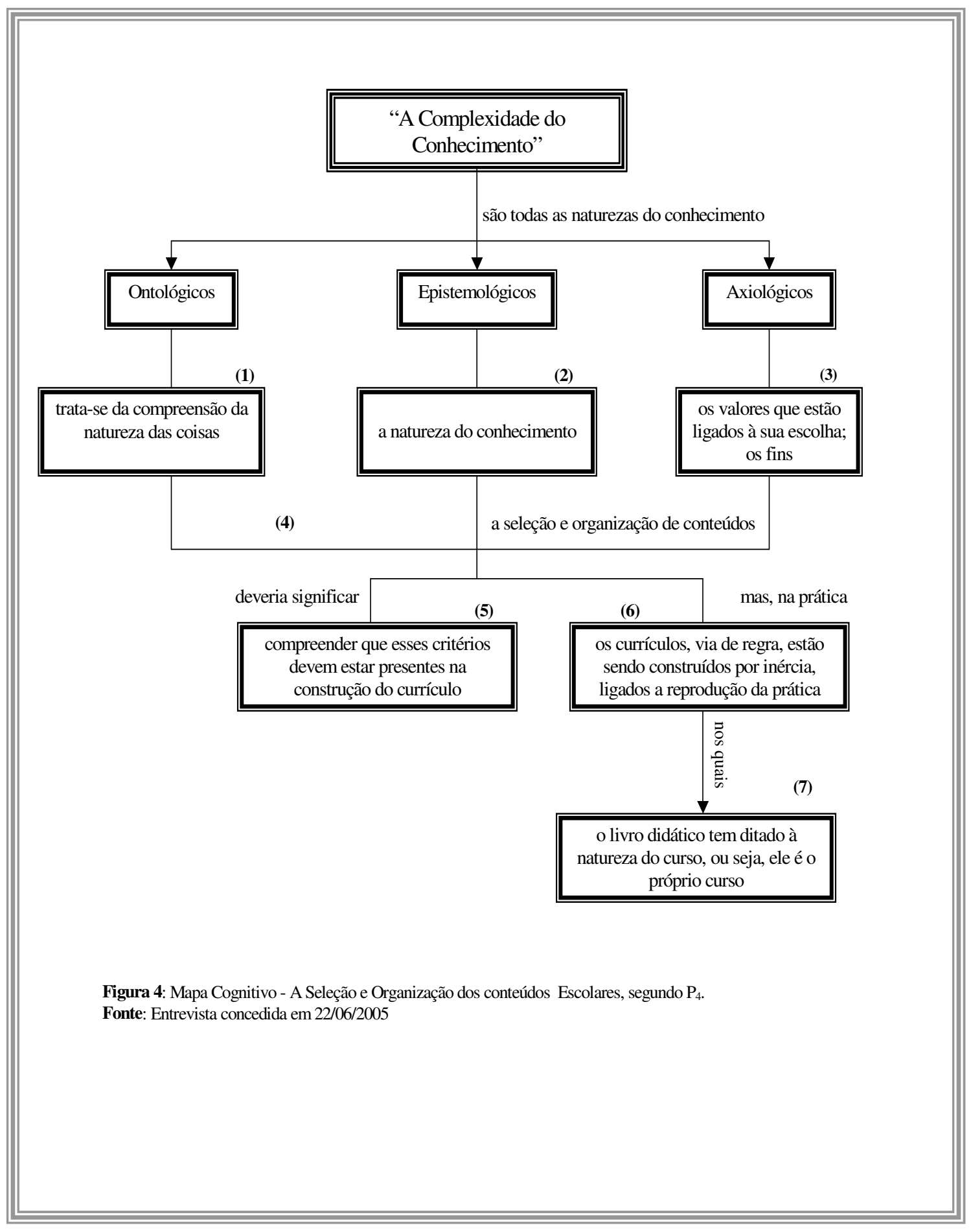


O primeiro refere-se à compreensão da natureza dos conteúdos. O segundo trata da natureza do conhecimento e o terceiro dos valores que estão ligados à sua escolha. As naturezas do conhecimento estão inseridas numa "Complexidade Geométrica do Conhecimento". No entender de $\mathrm{P}_{4}$ esses critérios deveriam estar conscientemente explicitados na construção do currículo. Porém, o que se observa, via de regra, é que o currículo tem sido construído por inércia ligada à reprodução da prática.

$\mathrm{P}_{4}$ aponta, ainda, que as práticas didáticas são recortes dessa totalidade do conhecimento, as quais podem ser intradisciplinares, multidisciplinares, interdisciplinares e transdisciplinares (figura 4A). Na intradisciplinaridade, a idéia está relacionada a uma sequiência lógica dos conceitos, dentro de uma linearidade, onde não se observam interlocuções, permanecendo como coisas isoladas Na multidisciplinaridade, os indivíduos conversam sobre seus conteúdos disciplinares, mas não se verificam avanços no sentido de se construir conexões. Na interdisciplinaridade busca-se intencionalmente fazer ligações entre os conteúdos disciplinares. Entretanto, essas conexões devem ser feitas pelo próprio indivíduo, fazendo superações que devem ser dominadas, além do seu conteúdo específico. Tal meta tem sido buscada com a elaboração de material didático, visando subsidiar o professor nessa nova perspectiva de trabalho. A transdisciplinaridade está relacionada à idéia de englobar todas as categorias do conhecimento, algo dificilmente conseguido na prática (figura 4A). 


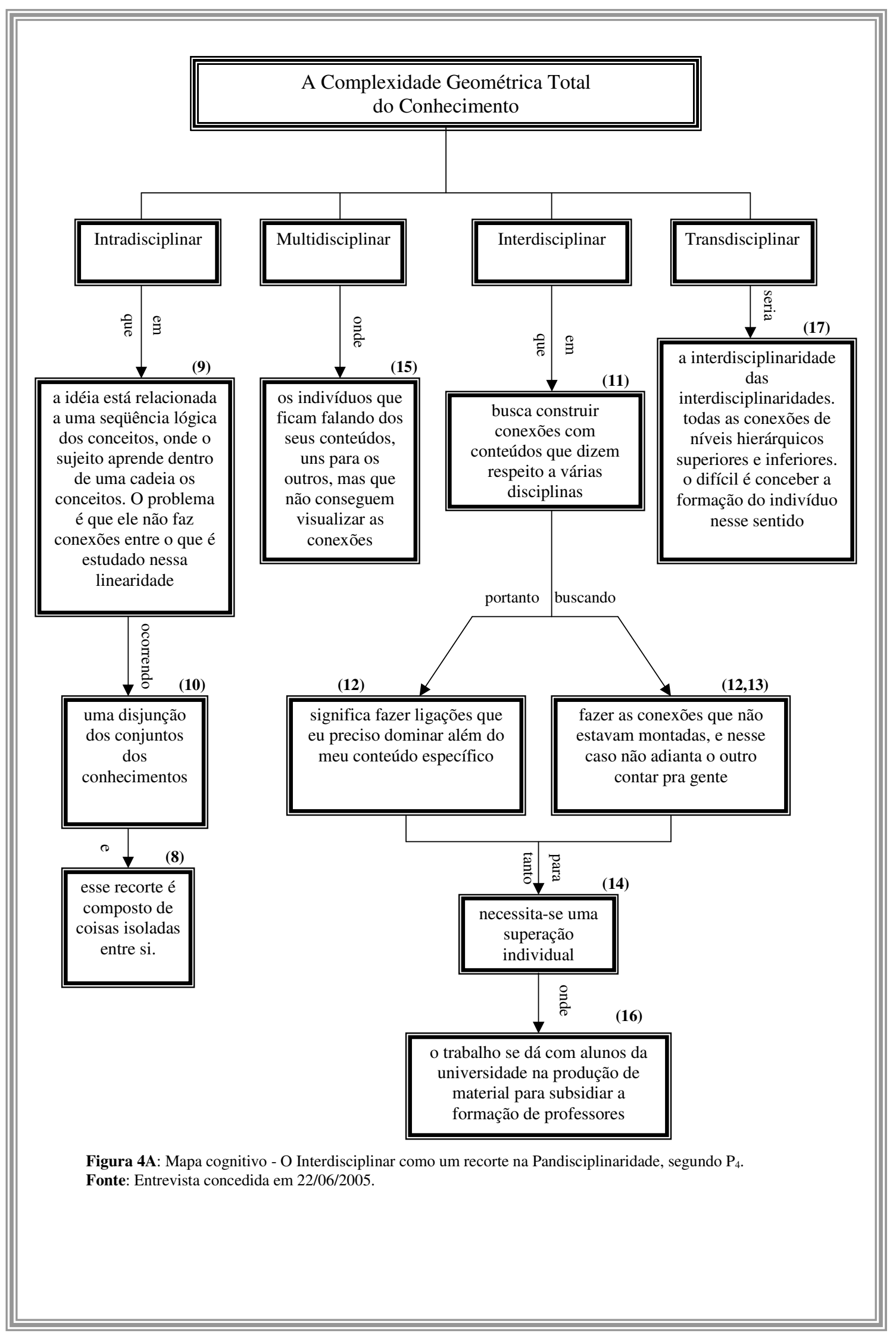


Para $\mathrm{P}_{5}$ a crítica à escola tradicional é pelo fato dela estar demasiadamente centrada na disciplinaridade e qualquer proposta que destoa desse mote, via de regra, é tratada como uma atividade à parte (figura 5). Isso não significa que as disciplinas deverão acabar, pois na organização da escola o espaço disciplinar é o mais importante; porém há uma necessidade de momentos que não sejam estritamente disciplinares, porque um projeto não se realiza no tempo de uma aula nem no espaço de uma aula.

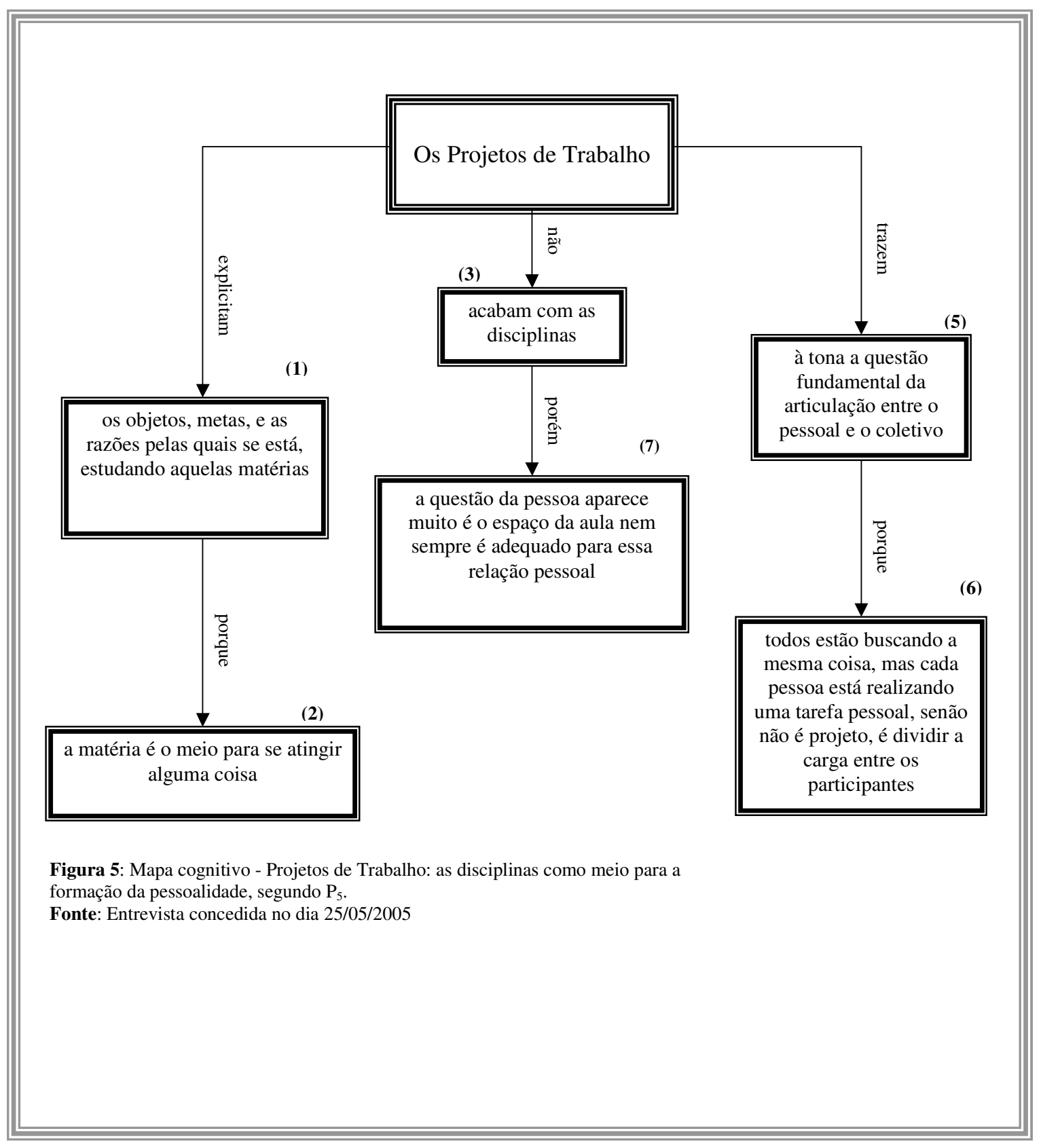


Para a Educação Básica $\mathrm{P}_{5}$ entende ser desejável que o aluno permaneça maior tempo na escola. Contudo, destaca que se a consolidação desse espaço se constituir em assistir aula, isso seria uma tragédia. Na sua concepção, o sistema atual de ensino tem aulas demais. Sobre a questão de propostas integradoras, menciona que elas estão dispostas em dois eixos. O primeiro denominado multi/interdisciplinar aponta para o incremento das relações disciplinares, pois não é razoável que elas permaneçam separadas, ou com fracas interações. Na multidisciplinaridade, segundo $\mathrm{P}_{5}$, as relações praticamente inexistem. O que se busca no primeiro eixo, multi/interdisciplinar é o aumento das interconexões, que ocorrem no campo estritamente disciplinar. No segundo, intra/transdisciplinar temos uma mudança de foco, pois no eixo intradisciplinar se afunila o objeto da disciplina, acirrando a necessidade de um olhar disciplinar mais específico; um aprofundamento que isola o especialista, levando a uma disjunção da própria disciplina. No eixo transdisciplinar, amplia-se para questões que estão além das disciplinas, como por exemplo, a genética, a ética e a educação etc. Neste eixo consideram-se as pessoas e não os objetos como fim. Finalmente, ressalta que não devemos evitar os "afunilamentos", mas temos que ter a grandeza de olhar para outras dimensões.

$\mathrm{P}_{5}$ considera que todo trabalho multi/interdisciplinbar amplia o entendimento sobre o objeto de estudo, permanecendo nos meios e não nos fins; isso significa perseverar no nível das disciplinas. Por outro lado, num tema transdisciplinar, como a educação, filosofia, etc. têm-se a pessoalidade como centro dos seus interesses. Pode ocorrer, vez por outra, que acabe por se limitar ao estudo da disciplina de filosofia, antropologia e sociologia, mas isso se configura como um equívoco. O que elas buscam em comum é colocar o ser humano no centro das atenções (figura 5A). 


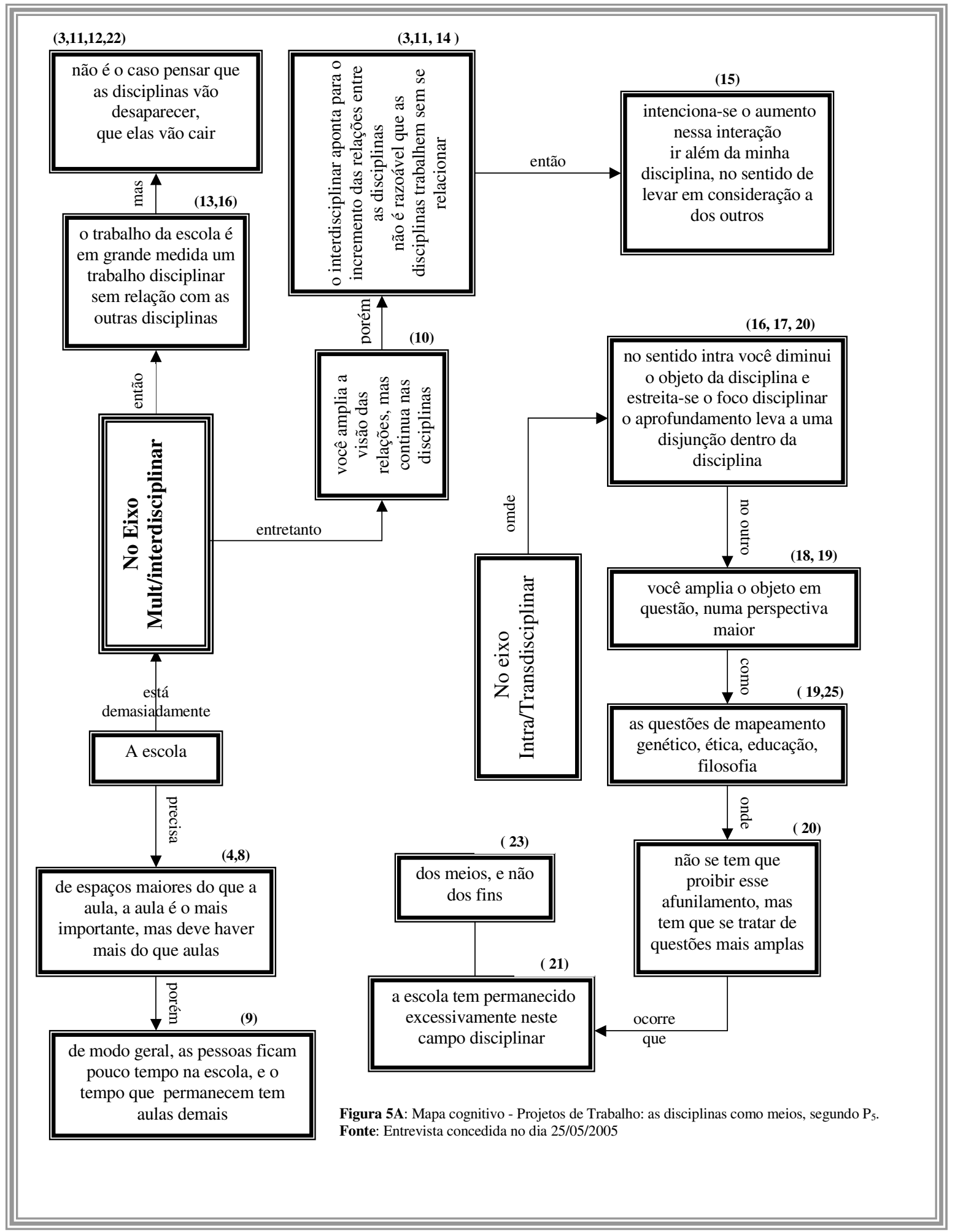


$\mathrm{P}_{6}$ comenta na entrevista que, quando convidado a produzir os parâmetros na área de física, não houve nenhuma orientação maior sobre interdisciplinaridade e contextualização; aliás, ressalta que essas palavras não faziam parte do seu vocabulário, nem dos colegas colaboradores. Supõe que o convite se deu pela sua participação histórica no "PEF" (Programa de Ensino de Física) constituído, por um grupo de professores/pesquisadores que propunham trabalhar a física a partir dos objetos do cotidiano; uma contextuação, na atual linguagem.

Com relação à interdisciplinaridade argumenta ser algo um pouco complicado pois, a princípio, ela foi mal compreendida; porque se entendeu que haveria a supressão das disciplinas, formando áreas de trabalho. Comenta que as primeiras reuniões para a elaboração dos documentos de conhecimento em física foi um pouco chocante, pois julgava haver uma idéia de uma grande área que subjaziam nas propostas dos documentos. Tais indícios se revelavam nos Parâmetros Curriculares Nacionais, ao intencionar formar três áreas de conhecimento. A interdisciplinaridade parecia propor a formação de professores por área. Afinal, esses documentos traziam um discurso da Secretaria do Governo e do MEC e, na época, o BID (Banco de Desenvolvimento Interamericano) que atuava intensamente nos projetos de financiamento da educação, sendo que no Brasil se atribuía à educação duas funções principais: domínio da língua e o domínio da matemática.

De acordo com $\mathrm{P}_{6}$ as disciplinas são epistemologicamente diferentes, com saberes constituídos de formas diferentes. Então, é necessário constituir a "consciência da diferença", buscando construir a interdisciplinaridade, multidisciplinaridade, transdisciplinaridade, ou pandisciplinaridade, por meio das disciplinaridades específicas.

Ressalta que o aluno/cidadão tem que ter o conhecimento dessa integração dos olhares diferentes, que se complementam para conhecer um objeto comum; o mundo à sua volta. Neste sentido, a química, a física e a biologia, com as suas metodologias próprias e diferentes atuações, possibilitam perceber os diferentes objetos e formas de trabalhar. A interdisciplinaridade deve aparecer desse diálogo entre essas várias formas de construção, evitando que os alunos concebam conceitos idênticos trabalhados nas disciplinas como coisas diferentes, como ocorre com a energia, por exemplo. Contudo, enfatiza que essa superação deve ser construída pelos professores (Figura 6). 
(19)

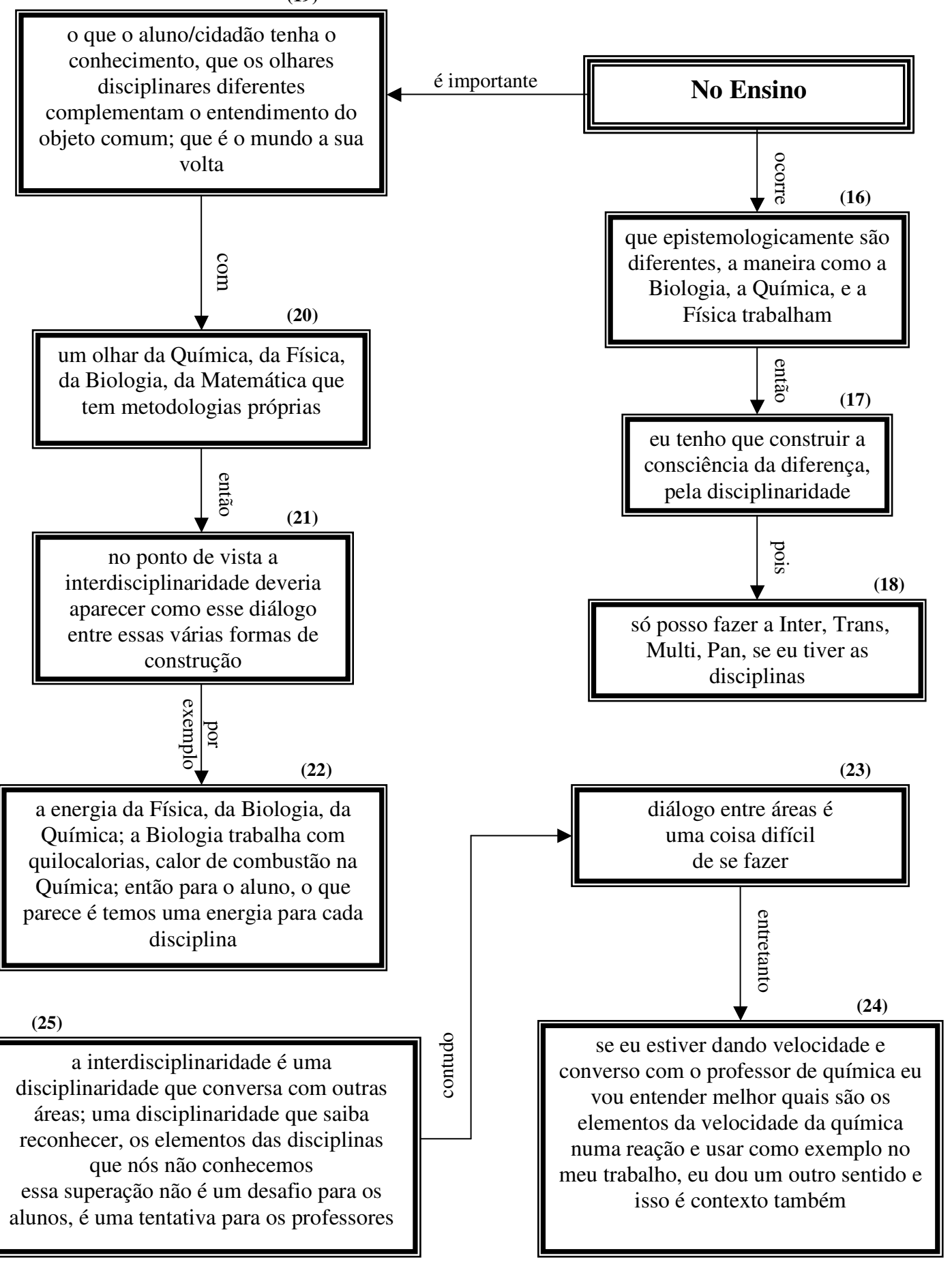

Figura 6: Mapa cognitivo - Disciplinaridade e Interdisciplinaridade no Ensino Médio, segundo $P_{6}$. Fonte: Entrevista concedida em 14/09/2005 
$\mathrm{P}_{6}$ porém entende a interdisciplinaridade como alguma coisa diferente do que supostamente traziam os documentos. Algo que se aproxima de fato da contextualização, onde os objetos do cotidiano são os mesmos para todas as ciências, mas com "olhares" disciplinares diferentes para os mesmos objetos. Assim, uma disciplina tem que necessariamente levar em conta o conhecimento da outra (Figura 6A).

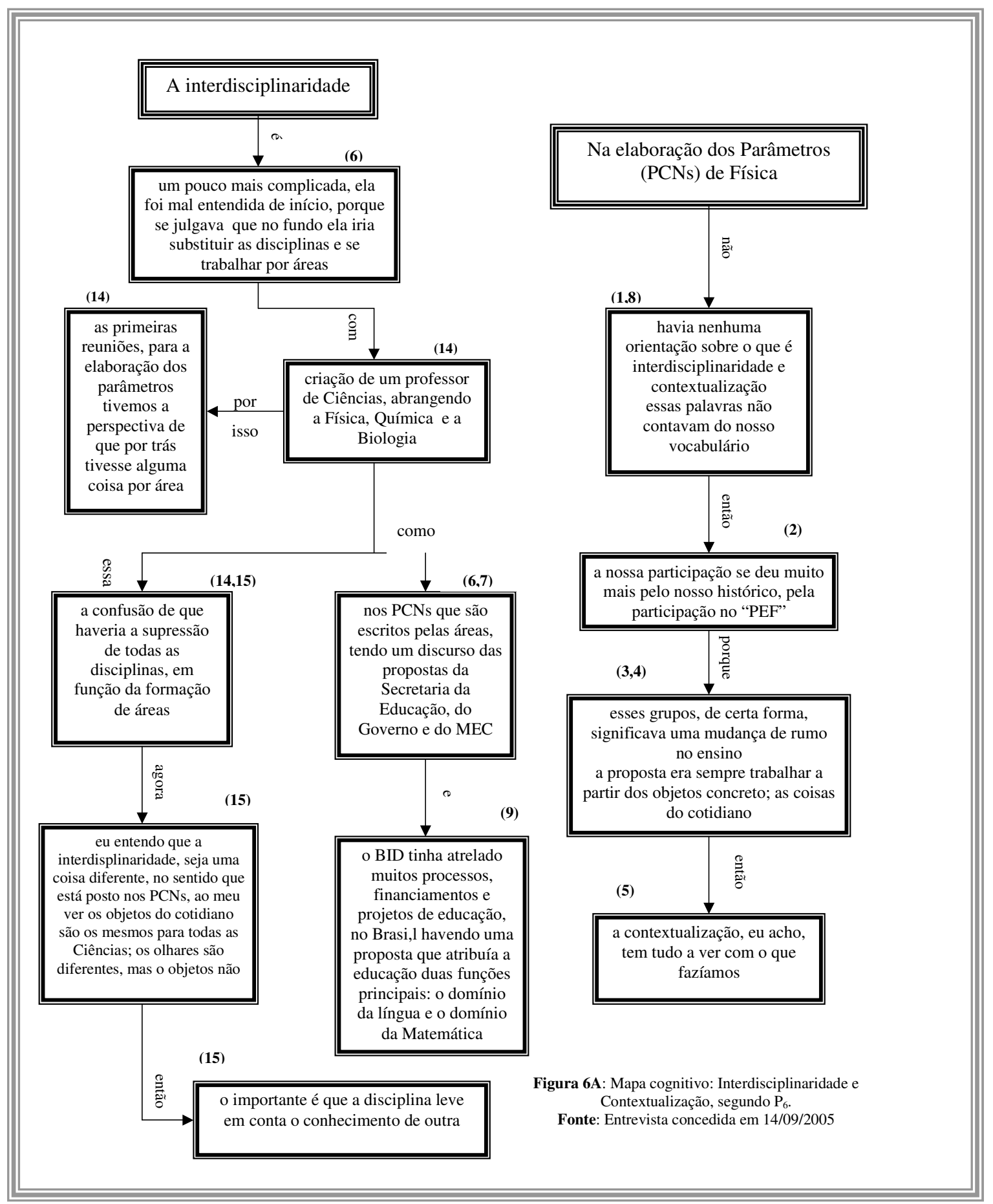


De acordo com $\mathrm{P}_{7}$ a disciplinarização é uma construção social, um processo histórico que levou à elaboração do conhecimento no pensamento moderno, o qual é estruturado de forma fragmentada (figura 7).

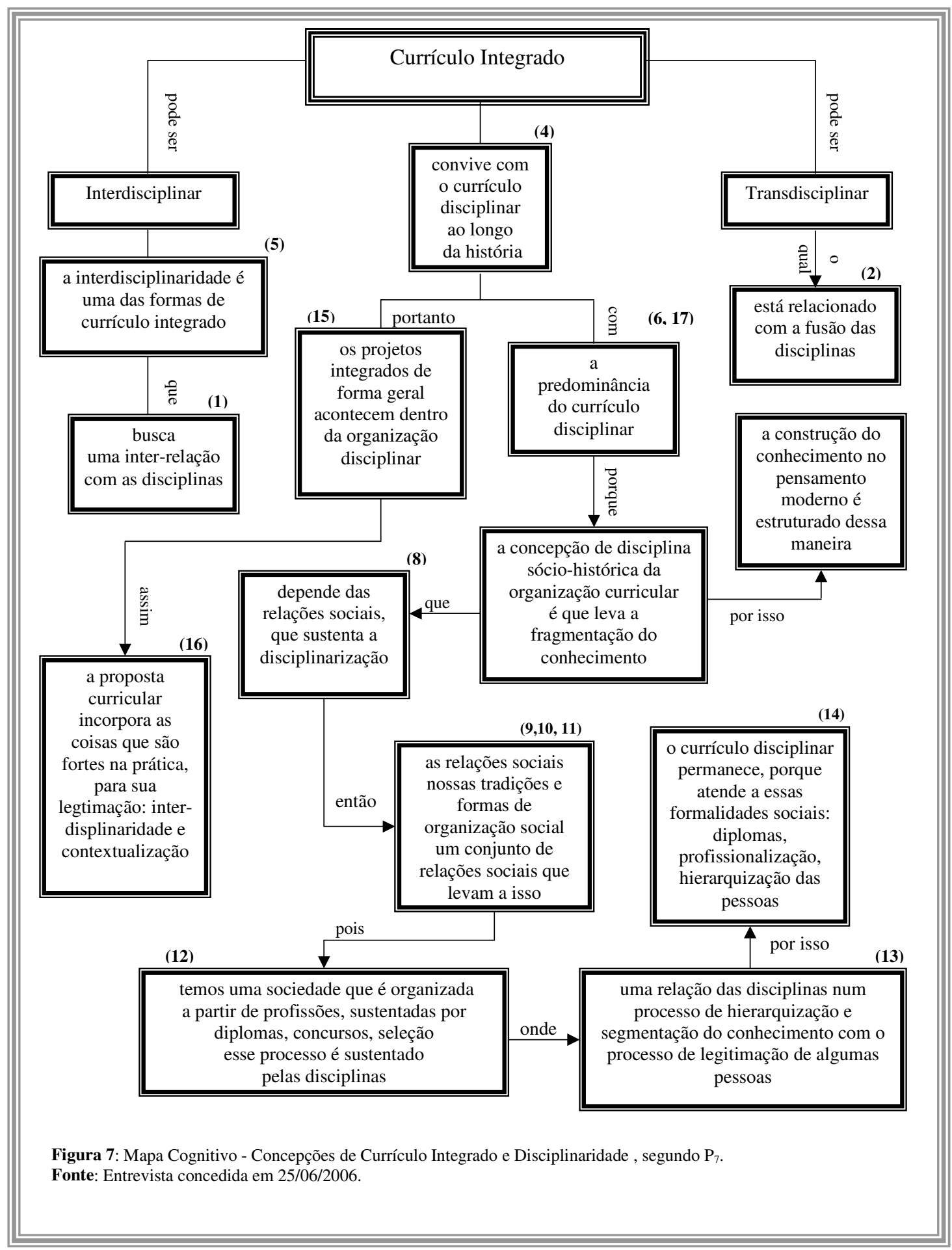


$\mathrm{P}_{7}$ considera que o currículo integrado seja algo mais amplo, capaz de abarcar Temas Geradores, Temas Transversais, Projetos etc. A interdisciplinaridade é apenas uma das formas desse currículo, a qual está relacionada com a inter-relação das disciplinas. Já a transdisciplinaridade ocorre com a fusão das disciplinas. Porém, mesmo considerando o currículo integrado nessa extensão, o currículo disciplinar é o que prevalece, porque ele é a forma pela qual se organiza o trabalho. Para $\mathrm{P}_{7}$ a concepção de disciplina sócio-histórica de organização curricular leva a uma fragmentação do conhecimento, estando diretamente vinculada às relações sociais. Nessas relações temos uma sociedade que é organizada a partir de profissões, que são sustentadas numa relação com diplomas, concursos, profissões e processos de seleção. Esse processo de hierarquização e segmentação do conhecimento é sustentado pelas disciplinas, que se traduz na legitimação de algumas pessoas, dizendo de alguma forma, quem tem o direito de falar nessa sociedade sobre química, sobre história, sobre geografia etc. Assim, o currículo disciplinar, ao longo da história permanece em virtude de atender a essas formalidades sociais: diplomas, profissionalização, hierarquização das pessoas, hierarquização dos saberes, segmentação dos saberes. Por isso, é que os projetos integrados de forma geral, acontecem dentro da organização disciplinar.

De acordo com $\mathrm{P}_{7}$ a proposta curricular incorpora coisas que são consistentes na prática para sua própria legitimidade, a contextualização e a interdisciplinaridade são exemplos. Dessa forma, o currículo integrado convive com o disciplinar, prevalecendo o disciplinar.

Para $\mathrm{P}_{8}$ a "ERR" (Experiências Reais de Estudo) é um estudo de caso que se identifica com a vivência das pessoas envolvidas. Elas são planejadas em âmbito universitário, mas há um recorte da vivência social das pessoas, ou seja, dos estudantes e dos professores envolvidos. A escolha das "ERR" pode ser do âmbito escolar, porém, via de regra, ela vem do cotidiano. Nessas situações procura-se trabalhar os conceitos do ponto de vista da química, da biologia e da física, o que produz um enriquecimento da linguagem. Nas "ERR" busca-se romper com a linearidade, uma ruptura que implica superar a lista de conteúdos e a fragmentação.

Para $\mathrm{P}_{8}$ na "ERR" o intercomplementar seria: multi, pluri, inter e disciplinar (Figura 8). 


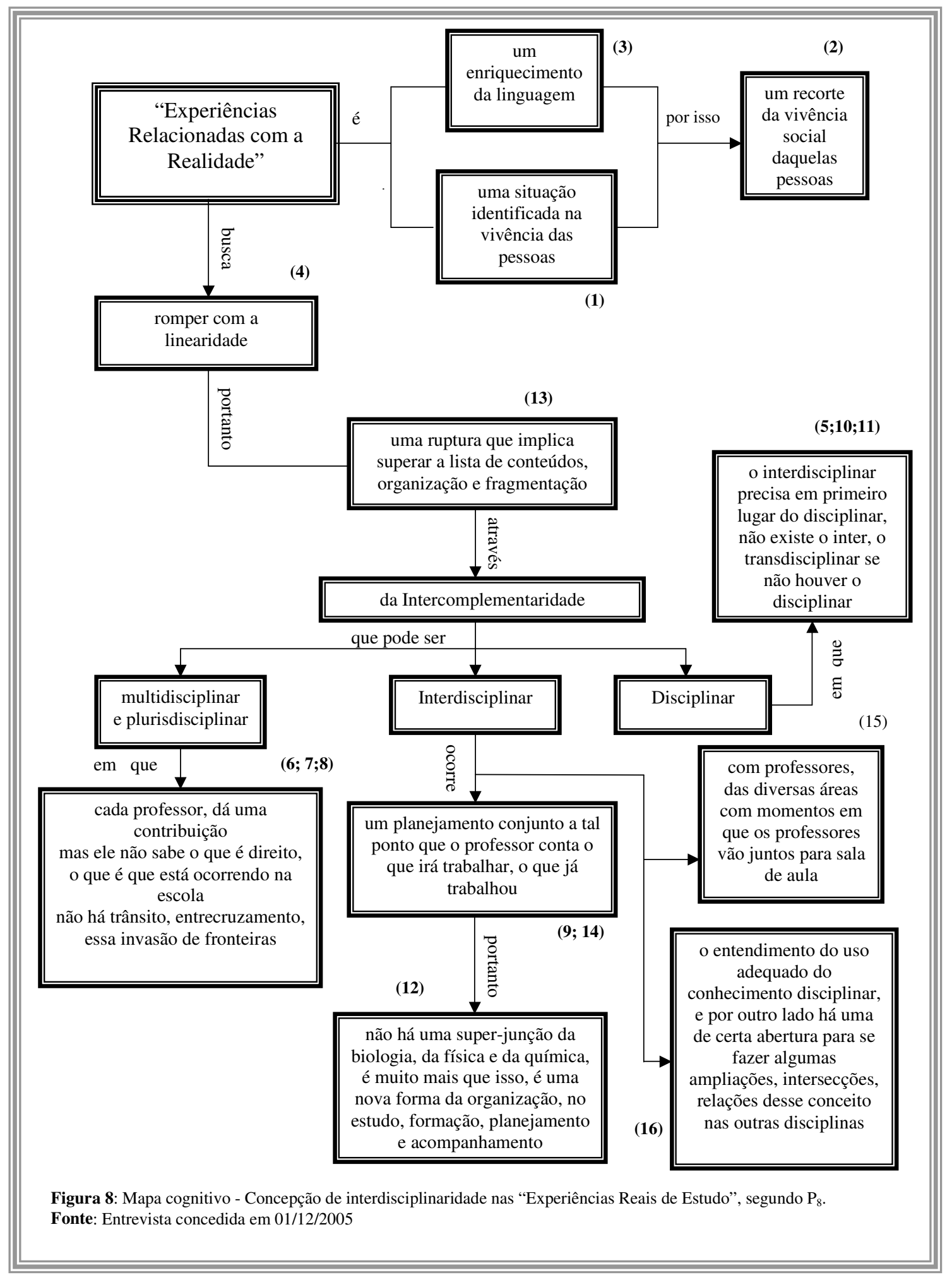


No multi e pluridisciplinar cada professor dá uma contribuição, mas não tem domínio do que ocorre na escola, pois não há "trânsito" entre as disciplinas, não ocorre uma invasão de fronteiras. No interdisciplinar é necessário um planejamento conjunto, a tal ponto que o professor socialize o que irá trabalhar com os demais. O que não significa uma super-junção da biologia, física e química. Seria uma forma de organização no estudo, planejamento e acompanhamento. Uma situação em que, às vezes, os professores das diferentes áreas vão juntos para a sala de aula. No interdisciplinar ocorre o entendimento do uso adequado do conhecimento disciplinar e ao mesmo tempo há uma abertura para se fazer alguma ampliação e relação desse conceito entre as disciplinas. $\mathrm{P}_{8}$ ressalta ainda que o interdisciplinar necessita em primeiro lugar do disciplinar.

Até aqui caracterizamos os mapas cognitivos obtidos a partir das entrevistas dos professores $\mathrm{P}_{1}$ a $\mathrm{P}_{8}$ que também são pesquisadores na área de "Ensino de". Nas suas entrevistas eles sugerem práticas de como trabalhar o conteúdo de forma integrada.

$\mathrm{O}$ esforço de $\mathrm{P}_{1}$, tem se concentrado na elaboração de atividades de formação de professores que vão evidenciar "a interação do indivíduo com o meio". Nesta perspectiva, é colocado o que o homem extraiu, modificou, devolveu ao ambiente. Intenciona-se, com isso, ampliar o campo de abrangência da disciplina de química, tornando mais perceptível e compreensível a sua atuação.

Para $\mathrm{P}_{2}$ e $\mathrm{P}_{8}$ a meta é estudar as experiências relacionadas com a realidade ("ERR"), ao mesmo tempo, pelos campos das disciplinas e da própria disciplina. Na primeira abordagem fazem uso dos conceitos da química, da física e da biologia e alguma coisa em matemática. Neste caso, as interconexões são buscadas pelos próprios professores dos campos disciplinares diferentes. Na segunda, trabalham com situações compreendidas só pelo ponto de vista da química.

$\mathrm{O}$ empenho de $\mathrm{P}_{3}$ tem sido no desenvolvimento de atividades de investigação do meio, dentro das próprias disciplinas, as quais são oferecidas em cursos de formação no ensino de física (figura 3).

$\mathrm{P}_{4}$ atualmente desenvolve material de subsídio à formação de professores de física para a introdução da interdisciplinaridade na sala de aula. $\mathrm{Na}$ sua visão, a interdisciplinaridade está embasada em conexões que o próprio professor deverá fazer para tornar o objeto de estudo mais compreensível. 
Os dados revelam pontos comuns entre os entrevistados sobre a necessidade da abordagem dos conteúdos numa perspectiva mais integradora, ou seja, ensinar de uma maneira a dar sentido e significado ao que se propõe estudar, tornando-se, para isso, indispensável o aporte de outras disciplinas e a conexão entre os conteúdos da própria disciplina. Ou seja, as propostas de trabalho integralizadoras não prescindem da disciplinaridade.

No tocante à interdisciplinaridade existe o consenso de que as disciplinas colaboram para a compreensão do objeto em estudo sobre o qual se intenciona conhecer, embora o que se busca é compreender o objeto na sua integralidade, indo de certa forma, ao seu contexto com todas as suas complexidades. Tal desafio exige um esforço veemente em evitar a fragmentação ou compartimentalização. Nas palavras de $\mathrm{P}_{3}$, “O objeto é o 'todo' e a sua demarcação de pertencimento, ou o olhar de uma disciplina, apenas pressupõe uma mutilação nessa 'totalidade”"(informação pessoal).

Com relação à forma de como construir esse trabalho interdisciplinar na prática, temos alguns pontos incomuns (visões diferenciadas). Para $\mathrm{P}_{1}, \mathrm{P}_{3}$ e $\mathrm{P}_{4}$, ele deve ser feito na perspectiva do professor; ou seja, ele fazendo pequenas superações epistemológicas, permitindo conhecer os conteúdos de outras disciplinas. A interdisciplinaridade se configuraria no momento dessas apropriações. No entanto, para $\mathrm{P}_{2}, \mathrm{P}_{5}, \mathrm{P}_{6}$ e $\mathrm{P}_{8}$, a interdisciplinaridade é algo que deve ser construído entre professores de diferentes disciplinas. Os "olhares" diferentes é que vão possibilitar e ampliar a compreensão do objeto.

Para outras propostas integradoras, também o consenso não é uma realidade. No entendimento de $\mathrm{P}_{1}$, no transdisciplinar, não há uma matriz de disciplinas estruturadoras, elas apenas são introduzidas, a partir da necessidade da situação. Tal postura diverge de $\mathrm{P}_{2}$, $\mathrm{P}_{4}, \mathrm{P}_{5}$ e $\mathrm{P}_{8}$, pois para $\mathrm{P}_{2}$ e $\mathrm{P}_{8}$, o transdisciplinar está nos conceitos de uma dada disciplina, os quais são usados fora de seu âmbito, não respeitando sua concepção original, ocorrendo uma transgressão. Já para $\mathrm{P}_{4}$ a transdisciplinaridade seria uma interdisciplinaridade de complexidade superior, o equivalente a pensar nas disciplinas como um todo. Seria uma "interdisciplinaridade das interdisciplinaridades, ou seja, conexões que englobam todos os níveis hierárquicos: física com química, física com biologia, química com biologia etc.; formando pares, trincas, quádruplas, quíntuplas, enfim, todos os níveis.” (informação 
pessoal) $\mathrm{P}_{5}$ entende-a como algo que está além das disciplinas (a ética, a educação e a antropologia etc.) abordando questões que tem como centro a pessoalidade. Para $\mathrm{P}_{7} \mathrm{a}$ transdisciplinaridade ocorre com a fusão das disciplinas.

$\mathrm{Na}$ compreensão de $\mathrm{P}_{4} \quad$ e $\mathrm{P}_{5}$ a intradisciplinaridade é uma disjunção do conhecimento; um recorte disciplinar em que os conteúdos estudados permanecem isolados nas suas especialidades, não havendo conexão entre si. Opinião não partilhada por $\mathrm{P}_{2}$ e $\mathrm{P}_{3}$, pois no entender destes, ela seria justamente a conexão entre os conteúdos existentes na própria disciplina.

De acordo com $\mathrm{P}_{7}$ a interdisciplinaridade é uma inter-relação das disciplinas, com a predominância do currículo disciplinar.

\subsection{Análise dos dados referentes aos alunos da pós-graduação}

Na concepção de $\mathrm{P}_{9}$ a interdisciplinaridade não se dá com um determinado tema que as disciplinas vão desenvolvendo. Existe um tema e se faz necessário uma discussão dele com os conteúdos de diversas áreas (disciplinas). Uma "conversa" entre as disciplinas sobre o Tema ou Situação Problema ou algo parecido, pois, não é possível ao professor abarcar todas as disciplinas e nem todas as informações, devendo explorar outras fontes, outros meios, como por exemplo, os especialistas, as revistas etc. Induzir, também o aluno a fazer pesquisa sobre o assunto, deixando claro para ele, desde do início, que o professor não terá condições de abordar tudo sozinho, devendo solicitar a contribuição de vários especialistas (professores, técnicos etc.).

Com relação à forma de se desenvolver o trabalho interdisciplinar, julga que deva começar pelos professores e não por um único. Contudo ressalta que soe acontecer nas escolas públicas que um professor começa um trabalho diferenciado e os demais vão aderindo. Destaca a necessidade de que os professores estudem textos acadêmicos para entender a proposta interdisciplinar, refletindo e decidindo até que ponto a proposta deve ser incorporada à realidade escolar. Em seguida escolher um tema, e a partir daí selecionar os conteúdos para atender às necessidades do projeto.

Para $\mathrm{P}_{9}$ a interdisciplinaridade é uma proposta viável e importante para trabalhar o conteúdo, apontando-a como "o caminho", pois a educação não pode continuar com um 
saber escolar diferente do cotidiano; a interdisciplinaridade consegue fazer essa transposição didática, permitindo ao aluno fazer uma leitura do mundo.

$\mathrm{P}_{9}$ considera a transdisciplinaridade como algo transversal a todas disciplinas, que não fica apenas nas disciplinas (figura 9).

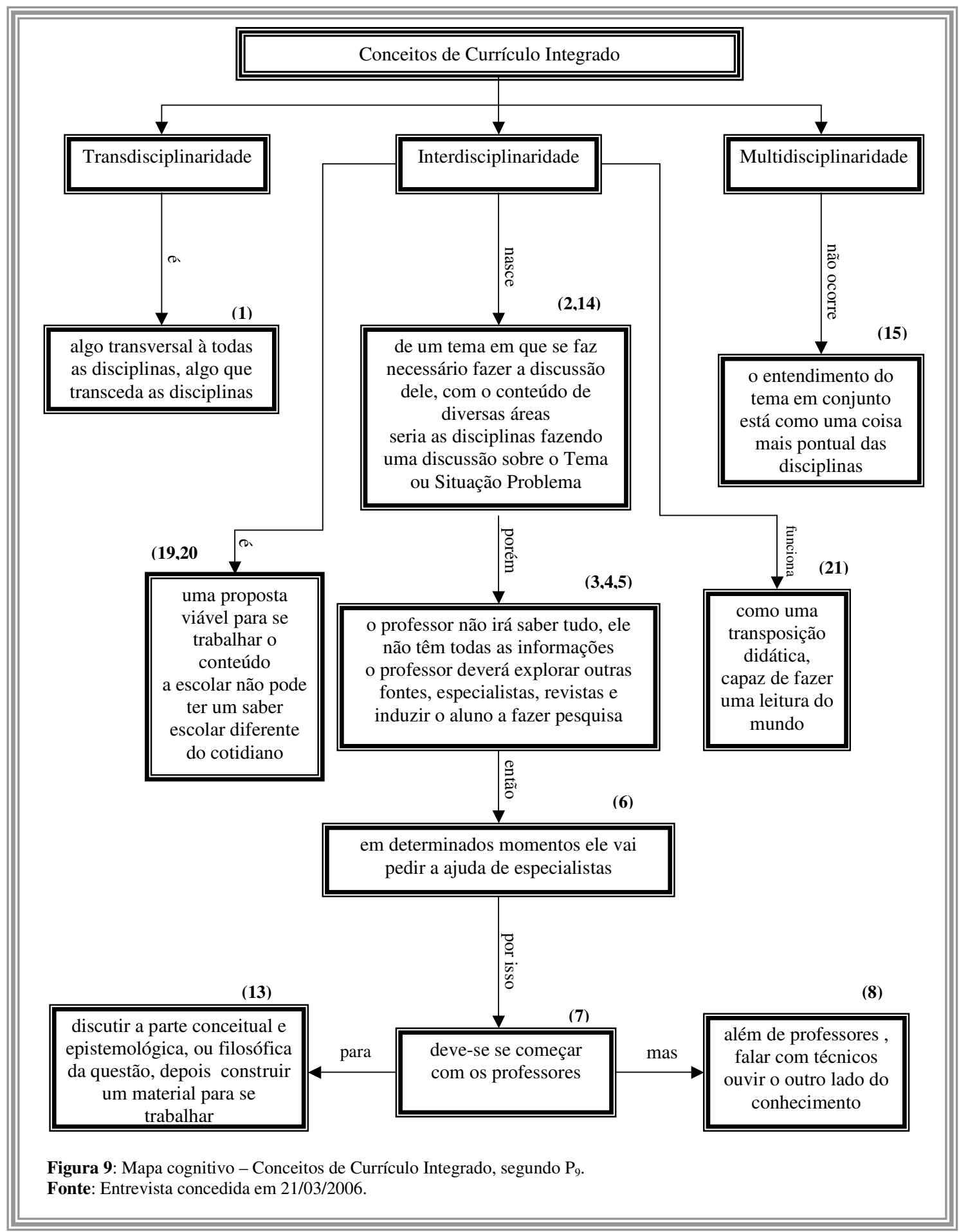


A multidisciplinaridade para $\mathrm{P}_{9}$ ocorre como algo mais pontual entre disciplinas, atendendo ao tema a ser desenvolvido, sem muita interação.

Sobre as condições de trabalho para a implementação da proposta, assevera que a equipe gestora (diretor, vice e coordenador) está mais envolvida com a parte administrativa e burocrática da escola, em detrimento das questões pedagógicas. Portanto, as Horas de Trabalhos Pedagógicos Coletivos (HTPCs) tem sido destinadas a discutir sobre gerenciamento escolar e quando há discussões de natureza pedagógica, elas não avançam do senso comum. Falta aos professores um certo profissionalismo. Isso resulta que a interdisciplinaridade é uma proposta viável para produzir conhecimentos, porém, inviável do ponto de vista "estratégico" (Figura 9A).

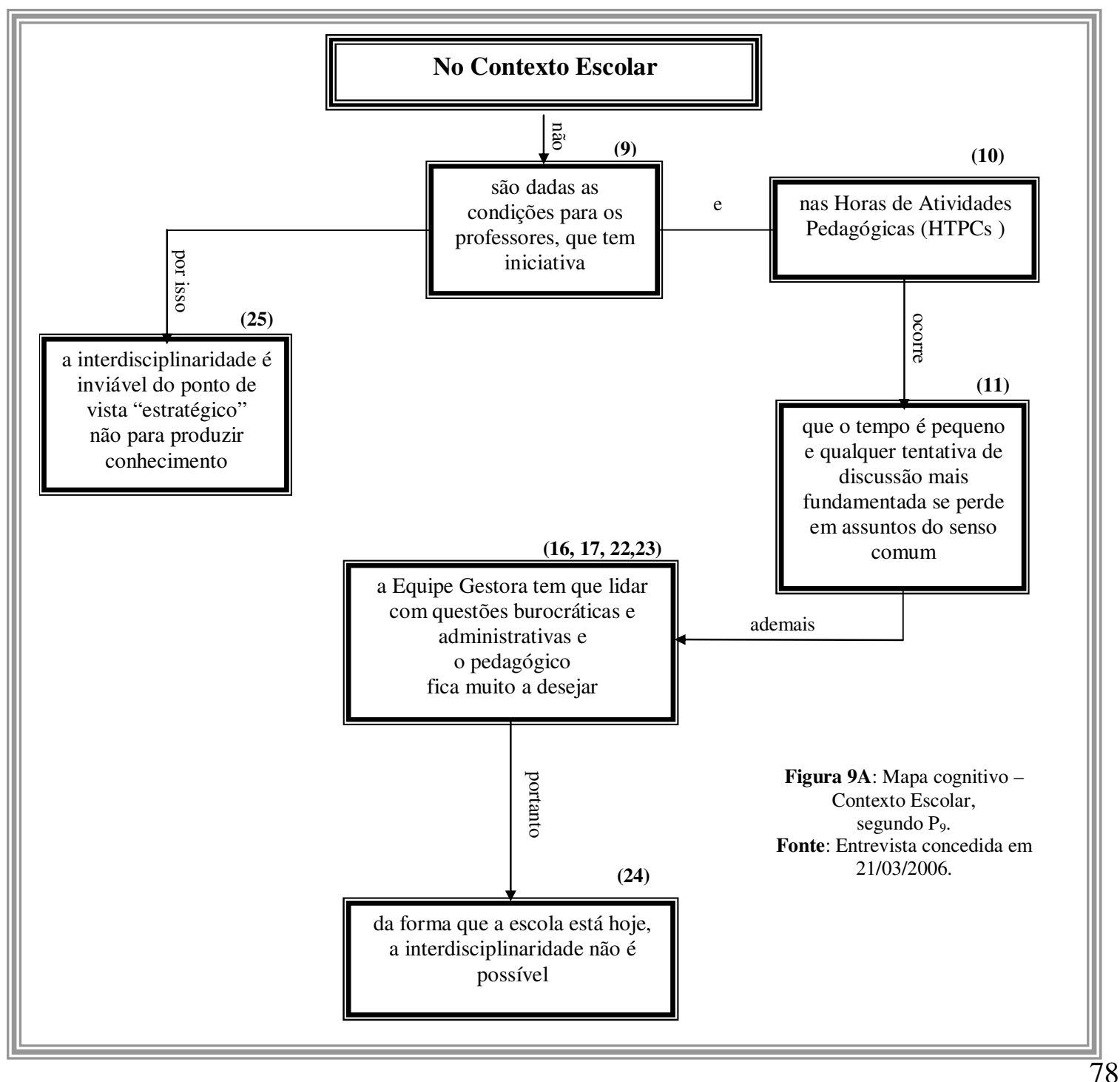


Para $\mathrm{P}_{10}$, o multidisciplinar ocorre quando se coloca um tema e cada disciplina vai trabalhando o assunto, sem que haja uma comunicação entre os participantes (figura 10).

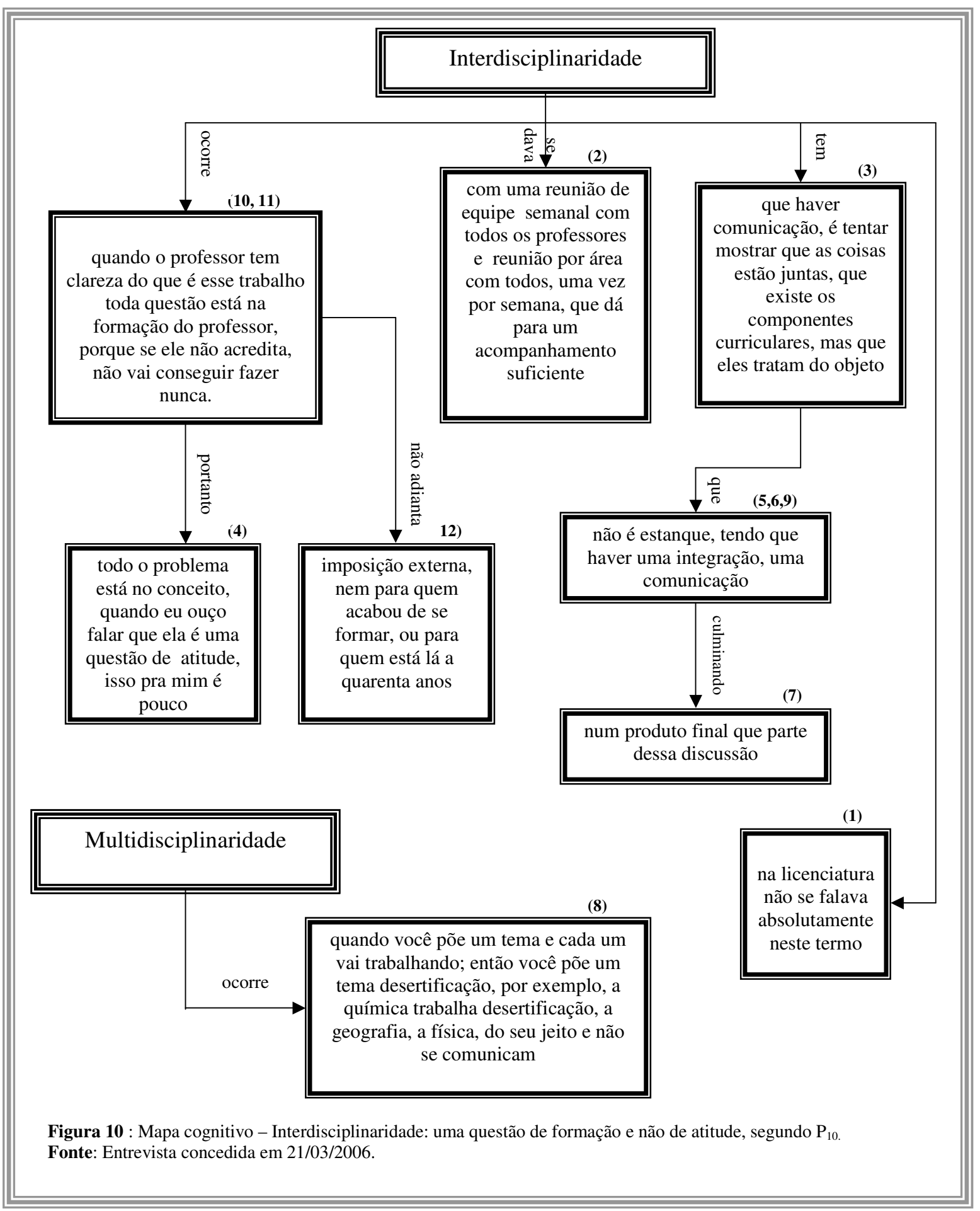


Já no interdisciplinar ocorre uma comunicação, onde se procura mostrar que as coisas estão juntas, que existem os componentes curriculares, mas eles tratam de um objeto em comum. Os encontros interdisciplinares se davam com os professores nas reuniões por área e havia um encontro da coordenadora com os professores de cada disciplina, o que possibilitava um acompanhamento suficiente (figura 10).

$\mathrm{P}_{10}$ ressalta que o currículo é disciplinar mas, a partir disso, pode-se mostrar que o mundo é interdisciplinar, e exemplifica o fenômeno da digestão que é biológico, físico, e químico. Portanto, o importante seria compreender o processo como um todo.

$\mathrm{P}_{10}$ entende também, que é possível fazer um trabalho interdisciplinar na prática escolar, desde que o professor tenha clareza do propósito interdisciplinar, o qual está diretamente relacionado à sua formação, pois se ele não acredita, não irá conseguir trabalhar com propostas dessa natureza. E acrescenta, que as imposições externas não funcionam, nem para os professores que estão chegando, nem tampouco para os veteranos.

Já $\mathrm{P}_{11}$ argumenta que ouviu falar pouco da interdisciplinaridade. Praticamente esse contato se deu, quando iniciou seus estudos, visando o ingresso na pós-graduação. Durante a graduação ouviu falar muito vagamente desse termo, e não sabia realmente do que se tratava. Cursando as disciplinas da pós-graduação é que ouviu com maior freqüência a necessidade da interdisciplinaridade e do trabalho interdisciplinar. Os seminários de ensino da pós-graduação interunidades, também traziam discussões sobre essa necessidade, porém nada com grande profundidade. Sobre uma proposta interdisciplinar, $\mathrm{P}_{11}$ supõe ser uma necessidade da escola e não de um único professor, pois é comum falar que o ensino de química tem que privilegiar a interdisciplinaridade, onde se tem a impressão que o professor de química sozinho tenha que ser capaz de desenvolver dentro de um único assunto toda a interdisciplinaridade possível, ou seja, fazer uma abordagem biológica, social, física, histórica, geográfica etc. Para ele, o trabalho interdisciplinar não seria com um único professor, tendo que ter o conhecimento de todas essas especificidades. A interdisciplinaridade é atributo da escola e do sistema de educação que a adota. Nesse sentido, ela não é responsabilidade de um único professor, mas de todo corpo docente, devendo ser trabalhada por todos. Para sua realização, os professores devem conversar antes, combinando o que irá ser abordado, decidir sobre qual ponto e aspecto é interessante 
trabalhar; podendo, dessa forma, "varrer" o mesmo assunto com um espectro maior de disciplinas.

$P_{11}$ considera que a escola atual não tem condições de desenvolver atividades diversificadas, como por exemplo, o próprio trabalho interdisciplinar, dadas às condições de trabalho do professor. Existe um discurso do que deve ser feito, no sentido de melhorar a educação, mas na prática as condições reais de trabalho, não favorecem o estabelecimento dessas propostas (figura 11).

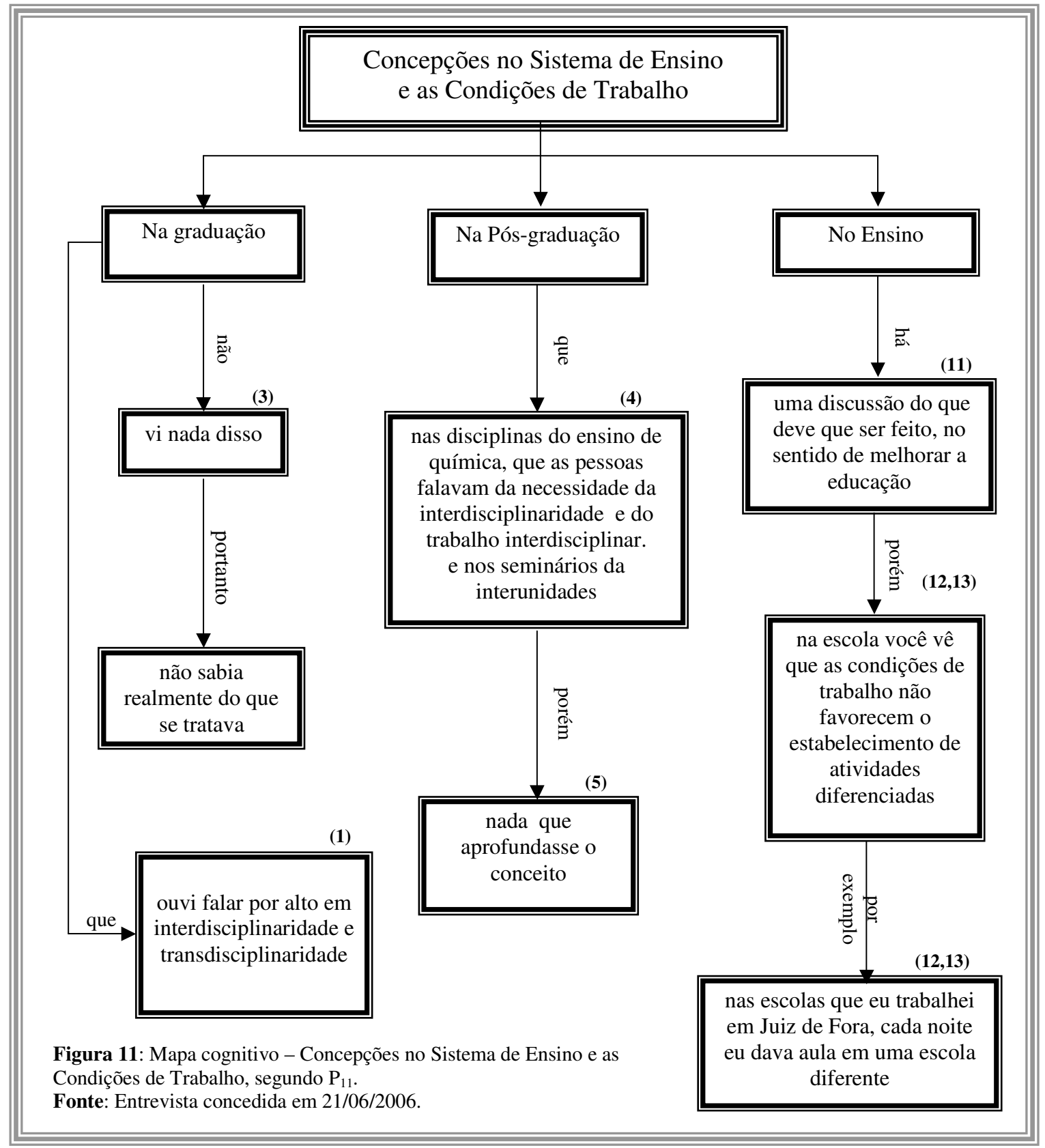


$\mathrm{P}_{11}$ menciona sua experiência, em que dava aula em três escolas diferentes, permanecendo pouco tempo em cada uma. Essa realidade inviabiliza qualquer atividade diferenciada, porque é necessário que os professores se reúnam, assentem, conversem e desenvolvam um projeto, estabelecendo o que será feito, e na prática esse tempo não existe. A interdisciplinaridade para $\mathrm{P}_{11}$ é abordar um assunto, através de várias disciplinas, sob a ótica de várias disciplinas (figura 11A).

Para implantar uma proposta interdisciplinar é necessário conhecer o perfil dos alunos e selecionar um assunto qualquer e depois dar uma abordagem química, posteriormente biológica etc. Em suma, primeiro escolher um assunto e depois cada disciplina pode verificar o seu enfoque próprio, dialogando disciplinas com disciplinas. $\mathrm{O}$ trabalho dos professores pode ser numa mesma aula, dependendo da estratégia de ensino que vão adotar, ou os dois professores juntos em esquema de debate numa sala, um professor de química e biologia e os alunos iniciando um debate e de acordo com o tipo de questionamento solicita-se o professor de química, ou o de biologia. Sobre como a interdisciplinaridade deve ser desenvolvida $\mathrm{P}_{11}$ reitera não ser por apenas um professor, pois ele tem que planejar a aula e estruturar seu projeto de trabalho, tendo que trabalhar em diversas unidades escolares; somada as dificuldades de formação, condições de trabalho e salário. Um único professor desenvolver tudo isso, é inviável, porque ele tem que dar conta não só sobre sua formação específica, mas gastar um tempo ainda maior pesquisando sobre outras áreas. Tal perspectiva poderia, talvez, ser desenvolvida quando as condições de trabalho fossem mais favoráveis.

Já a intradisciplinaridade para $\mathrm{P}_{11}$ é trabalhar dentro de uma mesma disciplina, transitando sobre os conceitos. Relacionar os conceitos que possam ser trabalhados ao mesmo tempo transitando entre um conceito e outro, fazendo links. Não como pacotes separados, como ocorre no Ensino Médio, em que, por exemplo, se aprende atomística e depois se estuda cinética; de forma compartimentada. 


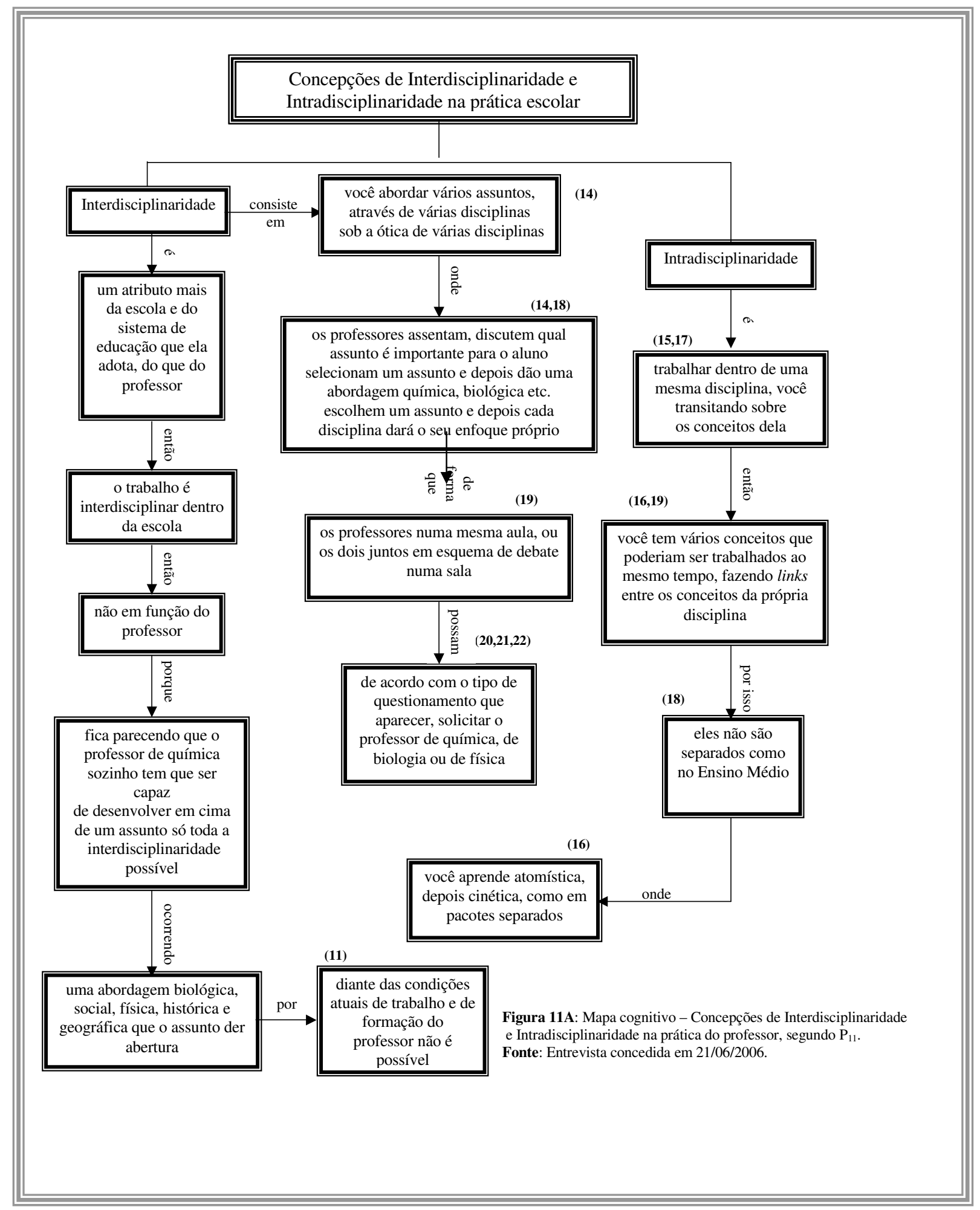


Sendo assim, para esses professores e pós-graduandos a interdisciplinaridade é obtida num grupo de professores. A interdisciplinaridade está relacionada com a forma com que o estudo coletivo pode evidenciar, ou esclarecer o contexto. Esse esclarecimento é feito pelos professores, alunos e especialistas de diversas áreas. O encontro entre os professores ocorre com o objetivo de selecionar os conteúdos que poderão elucidar o problema. Tal trabalho coletivo evidencia que a sua concepção de interdisciplinaridade se dá evidentemente, numa perspectiva entre professores e outros profissionais que ofereçam aporte.

$\mathrm{P}_{9}$ aponta como entrave para a implementação de propostas de currículo integrado a falta do domínio epistemológico do professor, quando se refere que o professor deve estudar o assunto com mais profundidade, pois a prática interdisciplinar, não é algo tão trivial como se pensa. Para isso, os envolvidos devem superar as discussões do senso comum muito presentes no cotidiano escolar.

No entender de $\mathrm{P}_{10}$ a interdisciplinaridade é uma comunicação entre as disciplinas, buscando mostrar que na natureza, as coisas não estão separadas e os componentes curriculares são uma complementaridade do objeto em comum. O propósito do interdisciplinar está ligado diretamente à formação do professor, o que implica considerar ideologicamente, como o professor entende o processo do conhecer. Finalmente, ao se considerar a forma de como se desenvolve um trabalho interdisciplinar, suas concepções se voltam para uma prática entre professores de disciplinas diversas.

Podemos depreender que para $\mathrm{P}_{11}$ a interdisciplinaridade deve ser feita entre professores, onde eles se apropriem de um tema comum, pertinente ao contexto das realidades escolares, e dialoguem sobre o que será o trabalho em cada uma das disciplinas; a mutualidade, entretanto, se esgota aí. Outro ponto marcante é que o impedimento de se fazer um trabalho interdisciplinar está associado às condições de trabalho do professor e não à dificuldade epistemológica. 


\subsection{Análise dos dados referentes aos professores de EM da Diretoria de Ensino de Tupã}

$\mathrm{P}_{12}$ entende que os trabalhos com projetos interdisciplinares devam ser contextualizados e que os professores precisam tomar consciência disso. Eles devem se reunir por áreas e discutirem como cada disciplina irá trabalhar seu conteúdo de forma contextualizada (figura 12). Para ele, a interdisciplinaridade se realiza no dia-a-dia dos professores, nos encontros que eles têm nas escolas, nas conversas que mantêm, dentro e fora das HTPCs, onde uma disciplina, a partir de um determinado conteúdo, busca ajudar a outra a clarificar os conceitos. Segundo $\mathrm{P}_{12}$ isso tende acontecer naturalmente na escola; porém no desenvolvimento de projetos, isso ocorre de maneira mais sistematizada. A interdisciplinaridade para $\mathrm{P}_{12}$ é algo que vai muito além de uma simples ajuda entre professores; as disciplinas formam uma teia, um complexo disciplinar, em que os envolvidos falam a mesma linguagem.

No desenvolvimento de temas transversais defende que o professor deva compreender assuntos que não sejam específicos da sua disciplina. Para isso, ele deverá buscar ajuda com os professores de outras disciplinas.

Para $\mathrm{P}_{13}$ a interdisciplinaridade é o relacionamento de uma disciplina com outra, uma colaboração que não fica apenas no tema proposto; há um objeto de estudo em comum e cada disciplina busca estudar o assunto dentro da sua especialidade, procurando esclarecer as situações (figura 13).

$\mathrm{P}_{13}$ defende que se o professor tiver uma formação em que as matérias são independentes, não será possível fazer um trabalho interdisciplinar. Caso contrário, ele será realizado mais facilidade. Menciona que falta ao professor mais leitura e reflexão sobre a proposta dos parâmetros curriculares, no sentido de uma nova visão epistemológica. Destaca também o problema da mobilidade dos professores, através de ingressos, formas de atribuição de aulas. No seu entendimento não há estabilidade, nem mesmo para os professores efetivos. Entende que a metodologia de pesquisa ajuda em práticas como a interdisciplinaridade, lamentando sua ausência nos cursos de licenciatura. Ressalta que, sem essa noção, o professor ao fazer projetos acaba misturando tudo, ou seja, ele não sabe 
discernir o objeto de estudo do conteúdo e os alunos saem prejudicados neste processo conturbado.

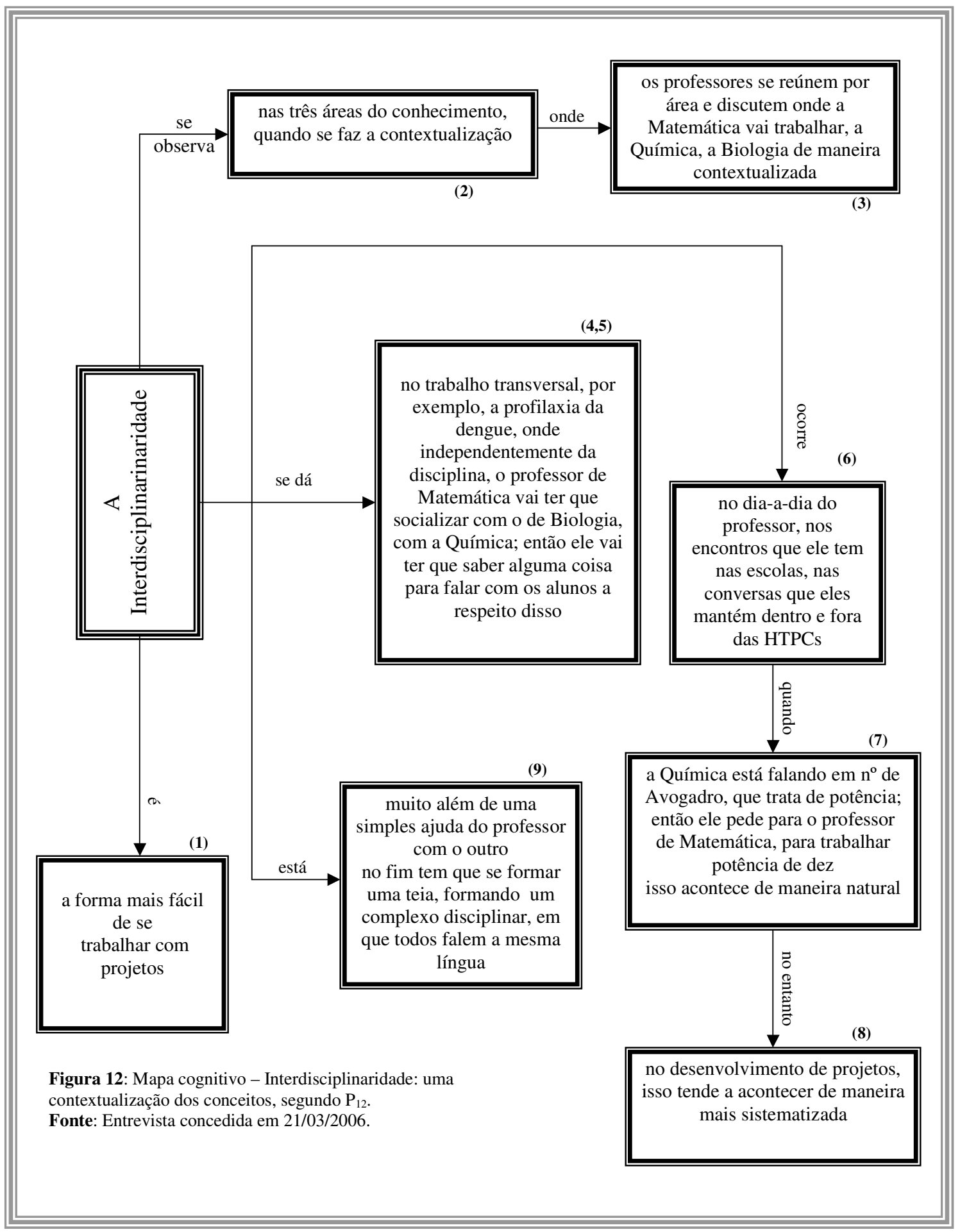




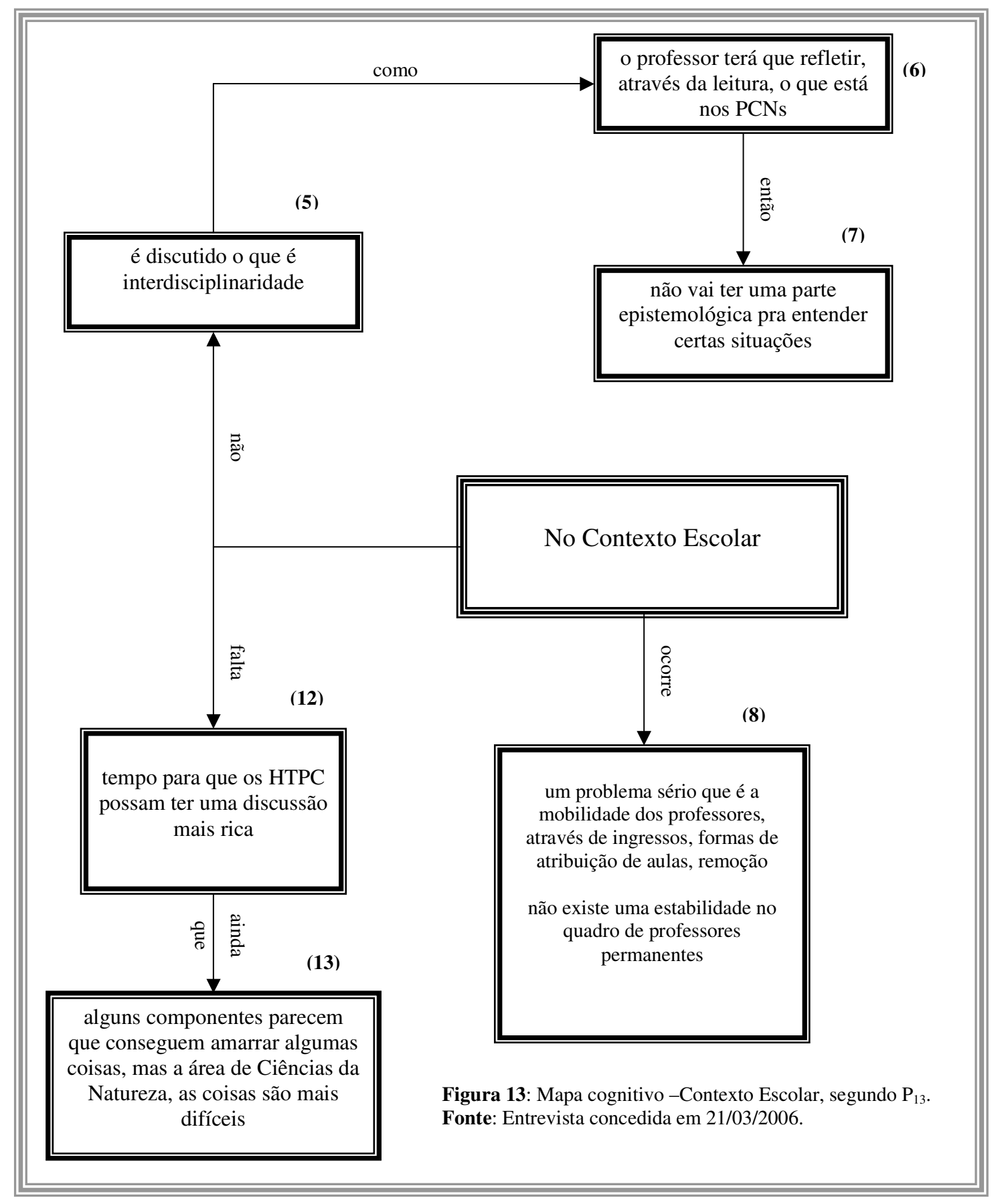


Sobre o tempo que a escola dispõe (HTPCs), julga ser insuficiente para discussões de maior profundidade. Porém, ao que parece, os coordenadores de áreas conseguem fazer a interdisciplinaridade entre os professores das diferentes disciplinas, indicando como cada disciplina poderia trabalhar um determinado assunto. Ela também se faz nos corredores, na sala dos professores, onde há troca de informações. Menciona ainda que, alguns componentes curriculares parecem conseguir "amarrar" os conteúdos mais facilmente, com exceção da área de Ciências da Natureza Matemática e suas Tecnologias, que permanece como nó.

Para $\mathrm{P}_{13}$, a multidisciplinaridade e a transdisciplinaridade têm definições diferentes, pois cada termo abrange uma instância de trabalho. Assim, a transdisciplinaridade ocorre quando alguns temas ou conteúdos permeiam todas as matérias obrigatoriamente, como nos temas transversais (figura 13A). 


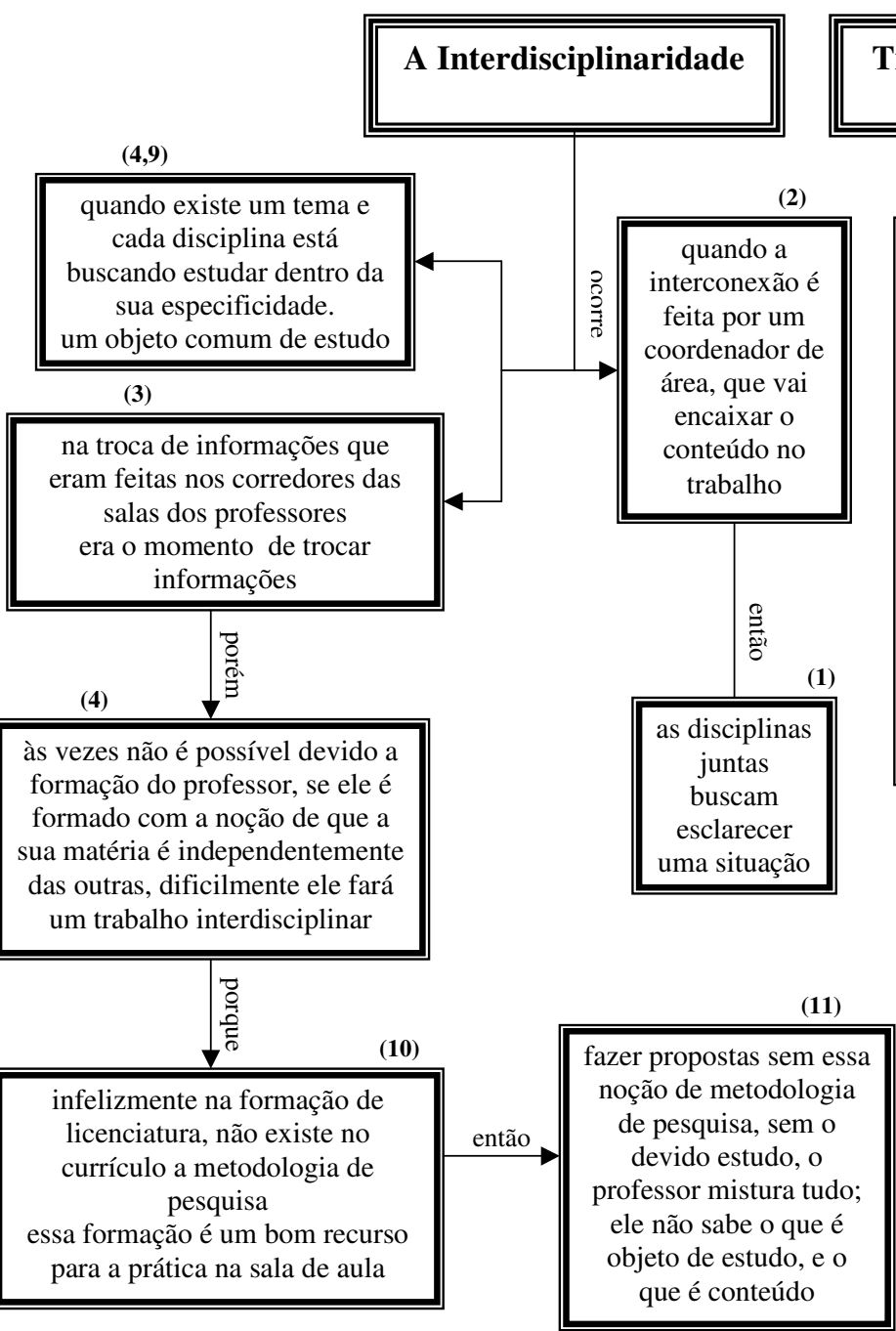

Transdisciplinaridade

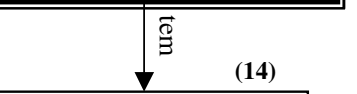

alguns temas de conteúdos devem estar permeando todas as matérias obrigatoriamente, como exemplo, temos os temas transversais em que todos os

componentes curriculares, independente do que seja, tem que fazer alguma inserção durante a apresentação do trabalho

(15)

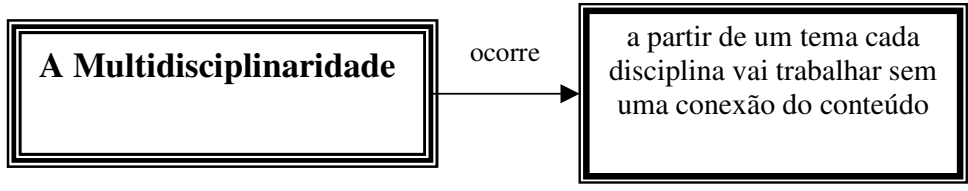

emelhantemente

Figura 13A: Mapa cognitivo Interdisciplinaridade: uma concepção epistemológica, segundo $\mathrm{P}_{13}$.

Fonte: Entrevista concedida em 21/03/2006
(17)

\begin{tabular}{|c|}
\hline algo semelhante ocorre na \\
pesquisa, cada um levanta a sua \\
hipótese, mas se a gente não \\
amarrar essas hipóteses para a \\
elaboração da tese; não há tese \\
\hline
\end{tabular}

a um paciente que está doente e vários médicos fazem o diagnóstico, mas não conversam para buscar coletivamente a solução da doença 
Para $\mathrm{P}_{14}$ os professores estão muito arraigados no conteúdo e trabalhando de forma tradicional. Sobre a proposta de trabalhos interdisciplinares, ouviu falar, mas não leu nada a respeito, não participou de nenhuma palestra, ou fez algum tipo de curso. Para ele foi uma experiência nova, que julgou interessante, pois o professor poderia mudar um pouco sua metodologia de trabalho, despertando no aluno maior interesse. Considerando que hoje os grandes problemas são a motivação e o interesse, com trabalhos interdisciplinares pode-se resgatar o interesse do aluno pela escola, principalmente pelos conteúdos.

Com relação ao empobrecimento do conteúdo, em virtude de se trabalhar interdisciplinarmente, defende que não ocorre e pensa o contrário. Porém, ressalta que cabe ao professor contextualizar o tema do projeto com os conteúdos devidos. O professor tem que ter um certo "jogo de cintura”, experiência para contextualizar, ou seja, inserir os conteúdos no projeto. Habilidade que geralmente ele não domina, não tem formação e realmente não é algo tão simples de ser feito. Destaca que atualmente nas faculdades fala-se em interdisciplinaridade, mas na prática pouco ocorre.

Sobre a integração dos outros professores $\mathrm{P}_{14}$ defende que no início foi um pouco difícil, pela resistência, mas com persistência, fornecendo livros, material de Internet; enfim material adequado, os demais professores acabam aderindo. Essa integração ocorria nas HTPCs, nos corredores, nas horas de folga, à noite, fora do horário de trabalho. Entretanto, não se dava entre todos os professores, mas entre os que estavam mais empenhados.

Para $\mathrm{P}_{14}$ a interdisciplinaridade ocorria entre os professores, quando trocavam idéias sobre como trabalhar os conteúdos, nas conversas, em todo momento (no intervalo, pelos telefonemas, na casa de um e do outro, na escola). Sobre a integração dos conteúdos, apesar de notar certas semelhanças, não houve qualquer discussão, pois se tratava de uma nova metodologia, não dando tempo para se discutir os conteúdos. Todavia, $\mathrm{P}_{14}$ afirma tê-la discutido com os professores mais próximos da sua disciplina, no caso biologia e física. Essa discussão resumia-se em saber se os mesmos conteúdos não seriam trabalhados pelos professores (figura 14). 


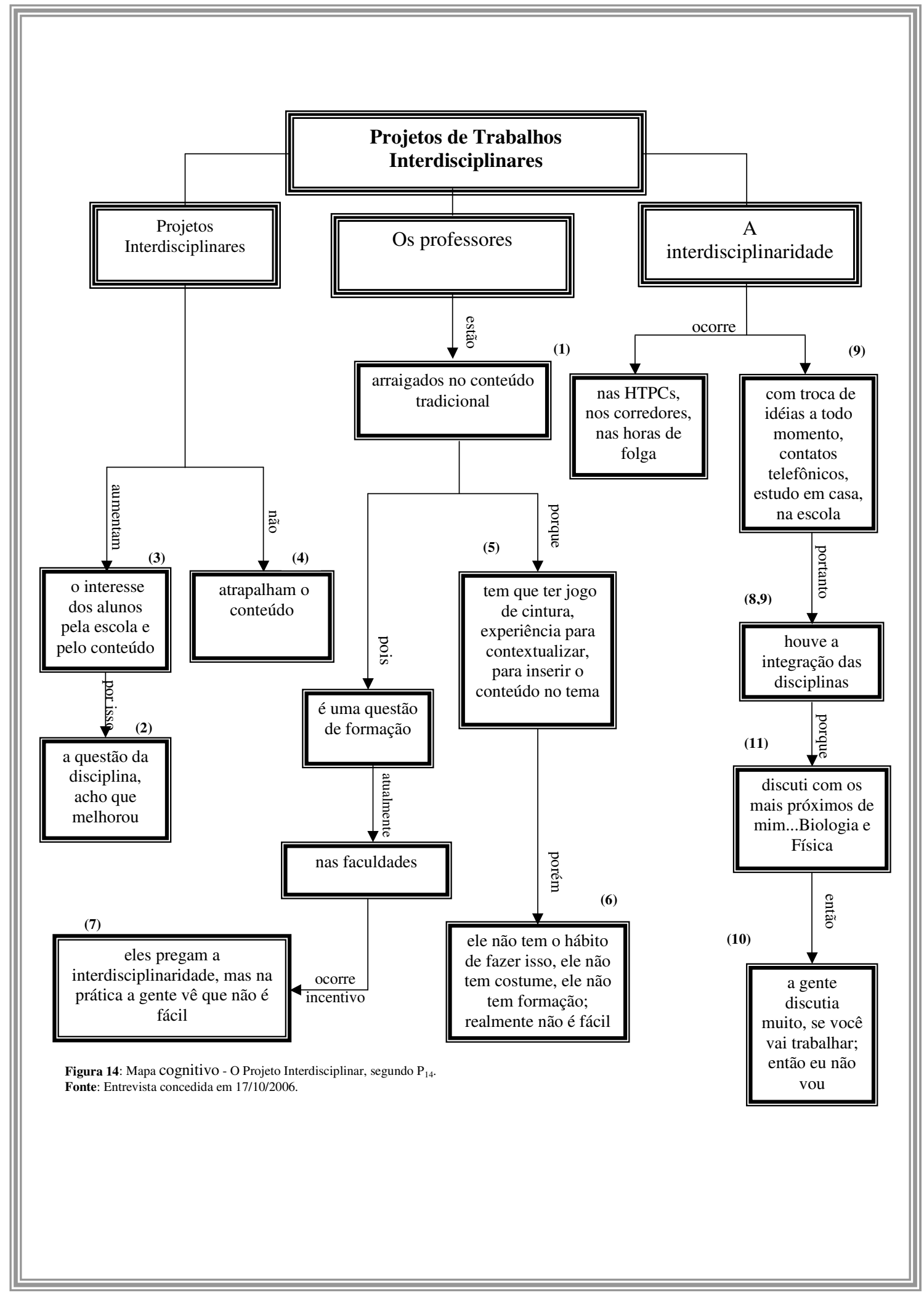


Para $\mathrm{P}_{15}$ os projetos interdisciplinares têm a capacidade de relacionar conteúdos da própria disciplina. No projeto do amendoim, por exemplo, trabalharam-se conceitos de mecânica, eletricidade e calor, ao mesmo tempo. No seu entendimento, o trabalho por projetos é mais atrativo para o aluno, pois ele vai a campo vivenciar as situações na realidade (figura 15).

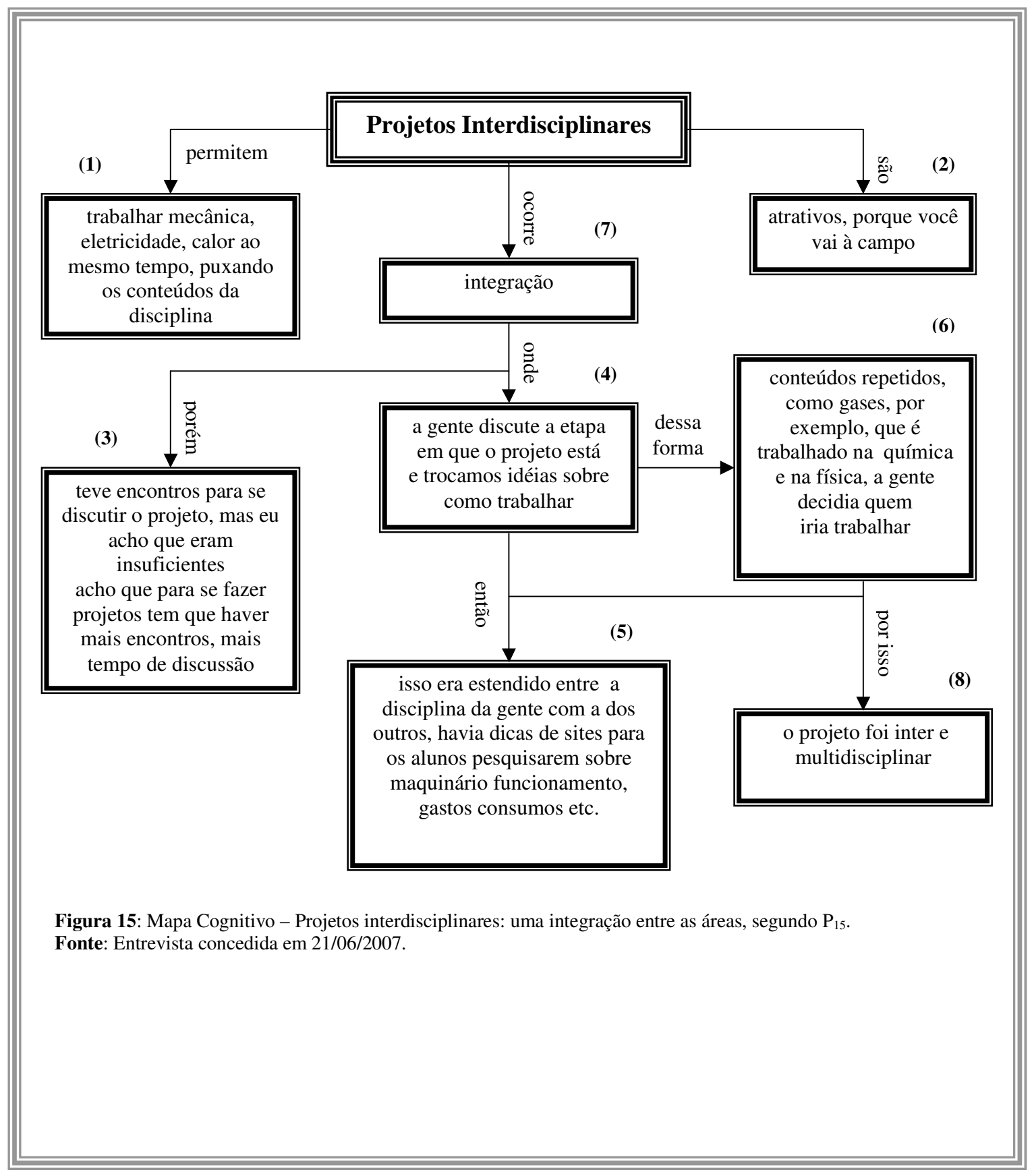


Com relação aos diálogos com os outros professores, $\mathrm{P}_{15}$ afirma que houve nos encontros para se discutir o andamento do projeto, porém julga que foram insuficientes. Para ele, trabalhos dessa natureza necessitam de mais encontros, mais tempo de discussão. No entanto, destaca que nesses pequenos momentos, discutia-se sobre o andamento do projeto. Em muitos desses encontros, os professores trocavam sugestões de trabalho. Esses diálogos adentravam aos conteúdos específicos, evitando que eles fossem trabalhados repetidamente.

Para $\mathrm{P}_{16}$ a construção do novo Ensino Médio é uma expectativa de mudança total na maneira de desenvolver o conteúdo e por conseqüência a obtenção de competências. Para tanto, o currículo que tinha o foco do ensino conteudista deixa de ser um fim em si mesmo, para ser um meio na obtenção das competências. Nessa nova proposta, o educando para ser o sujeito da ação, deve deixar a passividade predominante nas aulas expositivas, tornandose $\mathrm{o}$ protagonista da aprendizagem. Uma metodologia voltada para a prática contextualizada, com o foco na resolução de situações-problema, em que o conteúdo é mobilizado para resolver situações reais. A interdisciplinaridade propicia ao projeto o fim da fragmentação do conhecimento. Uma interdisciplinaridade que não prescinde da disciplinaridade. Dessa forma, o professor tem condições de trabalhar o relacionamento das disciplinas de forma a torná-las mais atraentes para o aluno.

Para que tais mudanças se efetivem na prática, segundo $\mathrm{P}_{16}$ é necessário algumas modificações: a primeira está relacionada com a formação dos professores, pois percebe-se algumas resistências a essa nova metodologia. A segunda diz respeito às condições de trabalho. O professor necessita de um maior número de horas-atividades, por exemplo, propiciando o encontro com os colegas. Para $\mathrm{P}_{16}$ essa é uma das condições indispensáveis a esse tipo de trabalho (figura 16). 


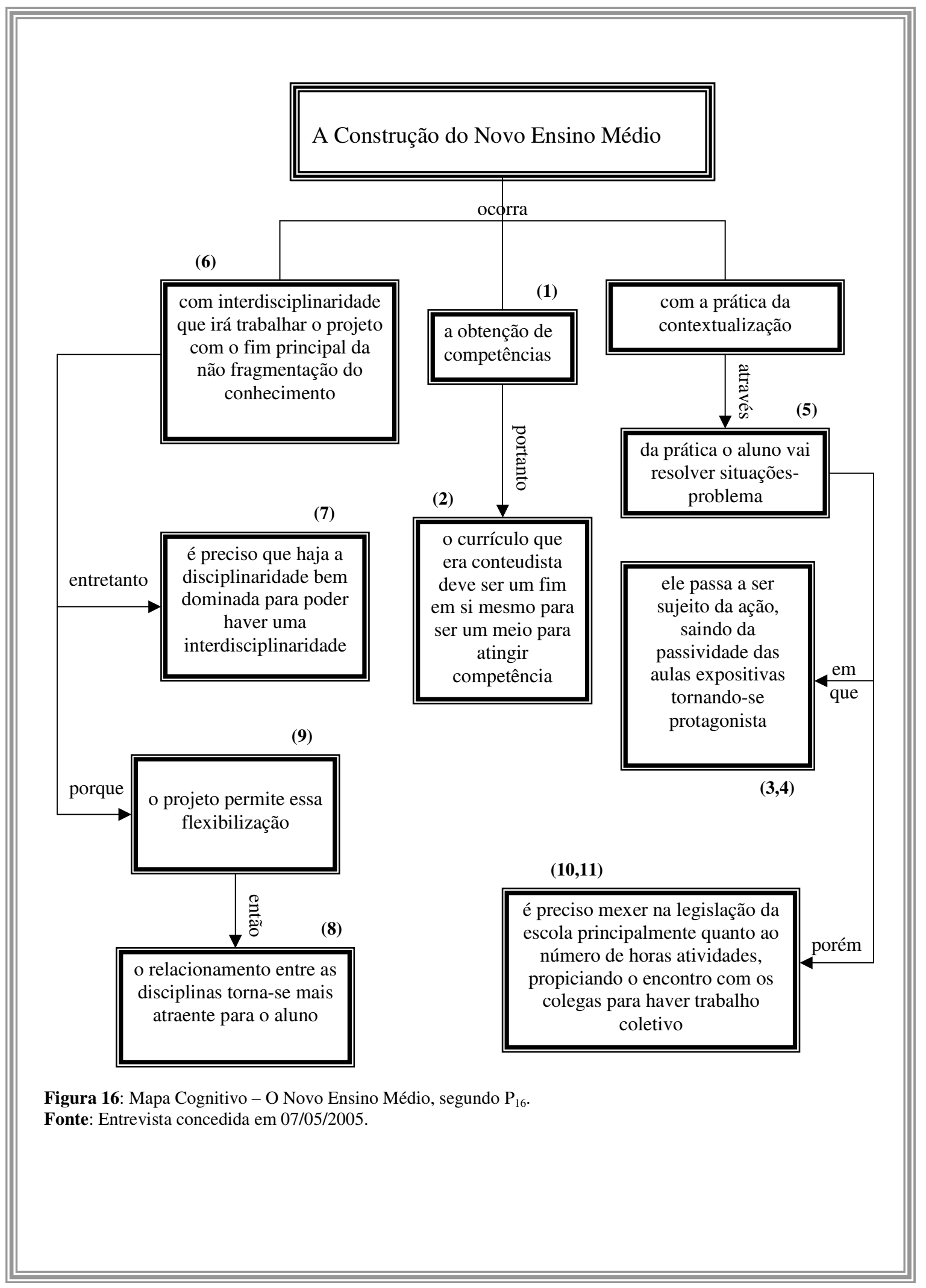


Sendo assim, para os professores do Ensino Médio em exercício, as condições estruturais na escola representam o principal impecilho para que a prática interdisciplinar aconteça. Revelam também o problema de domínio dos conteúdos e por isso, talvez, necessitem de uma prática coletiva para efetivar a interdisciplinaridade.

Para $\mathrm{P}_{12}$ a interdisciplinaridade deve se efetuar com a contextualização do que se pretende ensinar. A forma de desenvolvê-la se dá na perspectiva dos professores, que se ajudam mutuamente no desenvolvimento do conteúdo na sala de aula. Defende uma integração dos envolvidos, a ponto dos participantes desenvolverem uma linguagem comum.

Já para $\mathrm{P}_{13}$, a interdisciplinaridade é uma inter-relação em que as disciplinas procuram esclarecer situações, aumentando a compreensão do objeto de estudo. Para ele, o sucesso do trabalho está muito relacionado à concepção epistemológica do professor, estando diretamente ligada à sua formação. Com relação à sua efetivação na prática, ao que tudo indica, está na forma de como cada assunto vai ser abordado pelas disciplinas, o qual pode ser feito por uma orientação de um coordenador e pelas trocas de informações entre os professores.

Para $\mathrm{P}_{14}$ a interdisciplinaridade, ocorre quando há um diálogo entre os participantes, o qual se dá no sentido de trocas, sobre quais conteúdos deverão ser trabalhados e a forma de desenvolvê-los. Com relação à prática interdisciplinar, julga ser difícil sua implementação e permanência, devido à formação tradicional do professor, ou seja, uma questão relacionada, eminentemente à sua concepção epistemológica.

Para $\mathrm{P}_{15}$ os projetos interdisciplinares têm a capacidade de relacionar conteúdos da disciplina, com os das outras áreas do conhecimento. Essa integração vai desde estratégias até os tipos de conteúdos que devem ser trabalhados. Ao propor esse diálogo, $\mathrm{P}_{15}$ entende que a interdisciplinaridade deva ser trabalhada entre professores. Com relação aos "espaços" de encontro, $\mathrm{P}_{15}$ afirma que eles existem, porém são insuficientes e destaca que trabalhos dessa natureza necessitam de mais tempo de discussão.

Para $\mathrm{P}_{16}$ a interdisciplinaridade propicia o fim da fragmentação do conhecimento, porém ela não prescinde da disciplinaridade. Dessa forma, o professor tem condições de trabalhar o relacionamento das disciplinas de forma a torná-la mais atraente para o aluno. 
Para que tais mudanças se efetivem na prática, segundo $\mathrm{P}_{16}$ é necessário mudar a prática pedagógica do professor e melhorar as condições de trabalho.

\section{Capítulo 6 - Conclusões}

A partir: i) da leitura minuciosa e análise dos autores selecionados da literatura pertinentes ao tema interdisciplinaridade; ii) da análise dos documentos oficiais educacionais brasileiros; iii) da elaboração dos mapas cognitivos e análises a partir de entrevistas com professores universitários e professores do Ensino Médio foi possível agrupar as idéias apresentadas em duas categorias principais, as quais dispomos abaixo:

1) Interdisciplinaridade sendo construída por diversos professores de disciplinas diferentes (Interdisciplinaridade entre professores);

2) Interdisciplinaridade sendo construída pelo próprio professor, admitindo a possibilidade de se conhecer o conteúdo de outras disciplinas (Interdisciplinaridade do professor).

O quadro 1 representa como esses conceitos predominam na literatura, nos documentos oficiais e no discurso dos entrevistados.

Os autores selecionados em nosso trabalho de pesquisa de acordo com suas ideologias podem ser separados nas duas categorias elaboradas. Eles atribuem ao movimento positivista e de certa forma ao pensamento cartesiano, uma grande influência sobre o processo de especialização, disciplinarização e por decorrência, a fragmentação do saber. Eles também são unânimes em considerar que interdisciplinaridade depende fundamentalmente da existência das disciplinas, superando, de certa forma, o equívoco instaurado na década de 70, quando se cogitou acabar com as disciplinas em busca de uma pseudo-integração. Os que defendem a interdisciplinaridade entre professores, consideram que ela deve se constituir numa integração entre os participantes em todos os momentos, ou seja, início, meio e fim de uma pesquisa e ressaltam que o produto final de uma prática compartimentada não constitui uma produção interdisciplinar. Tal construção coletiva deve ainda buscar metodologia e linguagem comuns.

As convergências, ao que parece, se esgotam aí, pois as concepções de interdisciplinaridade dos autores se assentam, na sua maioria, em ideologias diferentes. 
Quadro 1: Concepções de interdisciplinaridade dos autores, documentos oficiais e professores entrevistados

\begin{tabular}{|c|c|c|}
\hline \multirow{2}{*}{$\begin{array}{c}\text { Autores } \\
\text { Documentos Oficiais } \\
\text { Professores Entrevistados }\end{array}$} & \multicolumn{2}{|c|}{ Interdisciplinaridade } \\
\hline & entre Professores & do Professor \\
\hline Jean Piaget & & $\mathrm{X}$ \\
\hline Jantasch e Bianchetti & & $\bar{X}$ \\
\hline Ludwig von Bertalanffy & & $\bar{X}$ \\
\hline Georges Gusdorf & $\mathrm{X}$ & \\
\hline Hilton Japiassu & $\mathrm{X}$ & \\
\hline Jurjo Torres Santomé & $\mathrm{X}$ & \\
\hline Ivani Fazenda & $\mathrm{X}$ & \\
\hline Nilson Machado & $\mathrm{X}$ & \\
\hline Antoni Zabala & $\bar{X}$ & \\
\hline \multirow{4}{*}{$\begin{array}{c}\text { LDB }^{* * *} \\
\text { PCNEM (1999) } \\
\text { PCN+(2002) } \\
\text { OCEM }(2004 ; 2006)\end{array}$} & - & - \\
\hline & & $\bar{X}$ \\
\hline & & $\mathrm{X}$ \\
\hline & $\bar{X}$ & \\
\hline \multirow{8}{*}{$\begin{array}{l}\mathrm{P}_{1} \\
\mathrm{P}_{2} \\
\mathrm{P}_{3} \\
\mathrm{P}_{4} \\
\mathrm{P}_{5} \\
\mathrm{P}_{6} \\
\mathrm{P}_{7} \\
\mathrm{P}_{8}\end{array}$} & & $\bar{X}$ \\
\hline & $\bar{X}$ & \\
\hline & & $\mathrm{X}$ \\
\hline & & $\mathrm{X}$ \\
\hline & $\mathrm{X}$ & \\
\hline & $\mathrm{X}$ & \\
\hline & $\mathrm{X}$ & \\
\hline & $\bar{X}$ & \\
\hline \multirow{3}{*}{$\begin{array}{l}\mathrm{P}_{9} \\
\mathrm{P}_{10} \\
\mathrm{P}_{11}\end{array}$} & $\mathrm{X}$ & \\
\hline & $\mathrm{X}$ & \\
\hline & $\mathrm{X}$ & \\
\hline \multirow{5}{*}{$\begin{array}{l}\mathrm{P}_{12} \\
\mathrm{P}_{13} \\
\mathrm{P}_{14} \\
\mathrm{P}_{15} \\
\mathrm{P}_{16}\end{array}$} & $\bar{X}$ & \\
\hline & $\mathrm{X}$ & \\
\hline & $\bar{X}$ & \\
\hline & $\mathrm{X}$ & \\
\hline & $\bar{X}$ & \\
\hline
\end{tabular}

Fontes: Mapas cognitivos das entrevistas; 2005, Documentos Oficiais (1996; 1999; 2002; 2004; 2006) e Literatura sobre a Interdisciplinaridade.

* Refere-se: ( $\mathrm{P}_{1}$ a $\mathrm{P}_{8}$ professores/pesquisadores $),\left(\mathrm{P}_{9}\right.$ a $\mathrm{P}_{11}$ alunos da pós-graduação) e $\left(\mathrm{P}_{12}\right.$ a $\mathrm{P}_{16}$ professores do Ensino Médio).

*** Não há evidências na LDB. 
Para Gusdorf, a interdisciplinaridade é uma proposta essencialmente filosófica/antropológica, pois o conhecimento existe para e em função do Ser. Piaget coloca a interdisciplinaridade numa categoria essencialmente epistemológica, ao afirmar que a superação do domínio conceitual de outras áreas está relacionada à forma de se conhecer comum, subjacente às diversas disciplinas. Japiassu aborda o conceito de interdisciplinaridade em âmbito epistemológico, evidenciando uma excessiva especialização no tocante ao conhecimento acadêmico. Para Santomé, esse conceito está posto em uma perspectiva epistemológica e metodológica ao afirmar que a interdisciplinaridade é uma metodologia de pesquisa, que não depende somente das disciplinas, pois está associada a certos traços da personalidade. No entender de Fazenda, o fazer interdisciplinar evoca no seu conceito a influência de caráter antropológico e metodológico, que se traduz na identificação de características de "personalidades interdisciplinares", tais como: respeito, humildade e atitude. Já para Machado, ainda que pesem os diversos motivos, a causa precípua do fazer interdisciplinar está decisivamente marcada pela concepção filosófica/epistemológica de conceber a maneira de se ensinar, a qual acaba por ditar a forma dos currículos. Para Zabala, a interdisciplinaridade é uma forma de se conhecer pela interação das disciplinas, sendo uma das maneiras de se organizar os conteúdos, ou seja, âmbitos epistemológicos e metodológicos.

Essas ideologias com vieses diferentes acabam por trazer, na prática, proposições interdisciplinares distintas. Senão vejamos, a concepção epistemológica de Piaget que a interdisciplinaridade pode ser obtida a partir do sujeito encontra eco nas proposições de Jantasch e Bianchetti, bem como na de Bertalanffy.

Por outro lado, observamos a defesa de uma proposta de interdisciplinaridade obtida pela reunião de saberes num grupo. Isso poderia ser entendido numa prática na escola feita entre professores.

Essa proposta é difundida pelos autores: Georges Gusdorf, Hilton Japiassu, Jurjo Torres Santomé, Ivani Fazenda, Nilson José Machado e Antoni Zabala.

Nos documentos oficiais as duas categorias também estão presentes. Nesse sentido, a concepção epistemológica de Piaget do "sujeito interdisciplinar" encontra certa semelhança nos documentos oficiais: PCNEM-1999 e PCN+-2002. O conceito de estruturalismo de Piaget propõe que há uma forma comum subjacente ao processo do 
conhecer. Disso resulta, no nosso entendimento, na categoria do sujeito interdisciplinar. Pensamento sugerido no (PCNEM-1999) e defendido explicitamente no (PCN+, 2002), conforme discutido no capítulo 3. Já os documentos subseqüentes, OCEM de 2004 e 2006 assumem e direcionam os professores para um trabalho interdisciplinar obtido a partir de um grupo de professores, ou seja, a interdisciplinaridade sendo construída entre professores. Cabe ressaltar que a LDB não é explícita quanto ao conceito de interdisciplinaridade.

Essas diferentes posturas também se revelam nos dados das entrevistas com os professores. Entretanto, a postura de interdisciplinaridade a partir do professor aparece apenas em três dos entrevistados $\left(\mathrm{P}_{1}, \mathrm{P}_{3}\right.$ e $\left.\mathrm{P}_{4}\right)$. Todos os demais $\left(\mathrm{P}_{2}\right.$ e $\mathrm{P}_{5}$ a $\left.\mathrm{P}_{16}\right)$ acreditam numa interdisciplinaridade feita entre um grupo de professores, consonantes assim com a postura defendida pelas OCEM e divergentes da postura que aparece no PCNEM e PCN+.

$\mathrm{P}_{1}, \mathrm{P}_{3}$ e $\mathrm{P}_{4}$, acreditam que a interdisciplinaridade deva ser feita pelo próprio professor.

Para $\mathrm{P}_{4},[. .$.$] para me formar em física e em educação para fazer ensino de química,$ eu preciso fazer a conexão entre essas coisas que demanda tempo, muita leitura e muito estudo, estou tendo que ler duas áreas, tendo que fazer conexões que não estavam montadas, todos nós que vamos atuar nesta área temos que fazer essas conexões pessoalmente, não adianta o outro contar pra gente que fez, tenho que construir as minhas [...] (informação pessoal) ${ }^{22}$.

$\mathrm{P}_{2}$ considera que, [...] O melhor é você realmente criar grupos de professores que são inicialmente interdisciplinares [...] (informação pessoal) ${ }^{23}$.

Já Para $\mathrm{P}_{6} \mathrm{o}$ melhor seria [...] construir uma disciplinaridade que converse com as outras áreas, uma disciplinaridade que saiba reconhecer nela, os elementos das outras disciplinas, o que é muito difícil, porque nós não sabemos o que aparece na biologia, na química e nem na física. Isso é um desafio e certamente não é para o aluno, é para o professor [...] (informação pessoal) ${ }^{24}$.

No entendimento de $\mathrm{P}_{9}$ a interdisciplinaridade é um atributo da escola, e não do professor: [...] fica parecendo que o professor de química sozinho tem que ser capaz de

\footnotetext{
${ }^{22}$ Entrevista concedida em 22/06/2005.

${ }^{23}$ Entrevista concedida em 01/12/2005.

${ }^{24}$ Entrevista concedida em 14/06/2005.
} 
desenvolver em cima de um assunto só toda a interdisciplinaridade possível, ou seja, fazer uma abordagem biológica, social, física, histórica, geográfica, e que o assunto der abertura para ser feito. Eu acredito que isso não seria interdisciplinaridade, ela não seria exatamente isso, um único professor tendo o conhecimento de todas essas especificidades (informação pessoal) $)^{25}$.

Cabe ressaltar, entretanto, que tanto nos documentos como na fala dos professores/pesquisadores $\left(\mathrm{P}_{1}\right.$ a $\left.\mathrm{P}_{8}\right)$ fica evidente o consenso de que a interdisciplinaridade pressupõe a presença das disciplinas na escola.

\section{Considerações finais}

Os dados apontam que a interdisciplinaridade convive com concepções diversas tratando-se, portanto, de um conceito polissêmico. Tais evidências são constadas na literatura e identificadas nos documentos oficiais, pois enquanto os PCNEM e PCN+ sinalizam para uma proposta de trabalho interdisciplinar a partir do professor, o documento OCEM traz uma proposta diversa, em que a interdisciplinaridade deva ser trabalhada entre os diversos professores. Divergência que se faz presente, também, entre seus consultores e elaboradores. Enquanto, $\mathrm{P}_{1}$ e $\mathrm{P}_{3}$, participantes da elaboração dos documentos PCNEM e $\mathrm{PCN}+$, acreditam que a interdisciplinaridade deve ser feita a partir do professor, para $\mathrm{P}_{6}$, também elaborador dos mesmos documentos, ela deve ser feita entre professores de disciplinas diferentes. $\mathrm{P}_{2}$ e $\mathrm{P}_{8}$, que atuaram na produção dos documentos OCEM, entendem a interdisciplinaridade como uma prática construída entre professores da área, ou áreas do conhecimento.

$\mathrm{Na}$ prática da sala de aula entretanto, parece não haver divergências. Todos os professores do Ensino Médio entrevistados $\left(\mathrm{P}_{9}\right.$ a $\left.\mathrm{P}_{16}\right)$ são convergentes com a idéia de que a interdisciplinaridade é um conceito que se constrói num grupo de professores e em comum acordo com a equipe gestora da escola, ainda que a concepção de interdisciplinaridade revelada por eles seja um pouco ingênua e superficial. Alguns dos professores entrevistados acreditam que a prática da interdisciplinaridade pode ser realizada através de encontros

\footnotetext{
${ }^{25}$ Entrevista concedida em: 21/03/2006.
} 
ocasionais como no café e na sala dos professores e não pressupõem a elaboração de um planejamento detalhado para tal.

Essa unanimidade pode estar revelando, além de uma postura epistemológica, uma dificuldade do "como fazer" na prática. Os professores entrevistados dão indícios sobre as suas dificuldades conceituais, conseqüentes de suas formações iniciais deficientes. Tais dificuldades apresentam-se como empecilhos para uma prática interdisciplinar consistente. Nesse sentido, vemos com bons olhos as tentativas de desenvolvimento de propostas integradoras reveladas por alguns professores/pesquisadores.

Ao que tudo indica, os professores necessitam de ajuda dos colegas e da instituição para colocar em prática o que se pede deles nos documentos oficiais, especialmente naqueles que defendem a interdisciplinaridade a partir do professor.

As divergências nas concepções de interdisciplinaridade reveladas neste trabalho, ao que parece, podem ter implicações na prática do professor, constituindo-se como elemento dificultador na construção de propostas interdisciplinares, pois julgamos ser pouco provável que ele consiga, nesse contexto, superar divergências de natureza epistemológica. 


\section{Referências}

Ackermann, F.; Colin, E.; Cropper, S. Cognitive Mapping: definitions, examples and resources, Chicago: Aldine, 1993.

Araújo F. T.; Riedg, D. L.Mapas Cognitivos como ferramenta de estruturação e resolução de problemas: o caso da pró-reitoria de extensão da UFSCar. Gestão e Produção. São Carlos, v. 10, n.2, pp. 145-165, 2003.

Bermejo, M. L.; González, T.; Mellado, V. Cognitive Maps for Interviews as a Procedure to Analyze Science Teachers' Conceptions of the Nature of Science. Editora Pamplona, Spain , 2004.

Bertalanffy, von L. ¿Que es la Teoría General de Sistemas? Disponível em: <http://www.portalga.ea.ufrgs.br/> Acessado: 17. jul. 2006.

Bertalanffy, L. von. Teoria geral dos Sistemas. 3. ed. Petrópolis, RJ: Editora Vozes, 1977.

Brasil, Orientações Curriculares do Ensino Médio/Ministério da Educação. Secretaria Média e Tecnológica - Brasília, 2006.

, Orientações Curriculares do Ensino Médio/Ministério da Educação. Secretaria Média e Tecnológica - Brasília, 2004.

, PCN+ Ensino Médio: Ciências da natureza, matemática e suas tecnologias/Secretaria de Educação Média e Tecnológica - Brasília, 2002.

, Parâmetros Curriculares Nacionais: Ensino Médio. Ministério da Educação. Secretaria Média e Tecnológica - Brasília: MEC/SEMTEC, 1999.

Lei de Diretrizes e Bases da Educação: Lei 9.394/96/ Rosa, A.P.L.L. \& Siqueira, V.A., organizadores. Rio de Janeiro: Editora Esplanada, 1998.

Chervel, A. História das disciplinas escolares: reflexões sobre um campo de pesquisa. In Boto, C. Nova história e seus velhos dilemas. Revista USP, São Paulo, 1994, n. 23.

Descartes, R. Discurso do Método. Regras para a Direção do Espírito. São Paulo: Editora Martin Claret, 2005.

Fazenda, I. C. A. Interdisciplinaridade: História, teoria e pesquisa. Campinas, São Paulo: Editora Papirus, 1994.

Fazenda, I. C. A. (org.). Práticas interdisciplinares na escola. 2 ed. São Paulo: Editora Cortez, 1993. 
Ferrara, F. N.; Mattos, C. Seleção e Organização de Conteúdos Escolares: Recortes na Pandisciplinaridade. Disponível em:

$<$ http://www.sbf1.sbfisica.org.br/eventos/epef/viii/PDFs/CO81_2.pdf > Acessado: 13 jan. 2006.

Gadotti, M. Interdisciplinaridade: Atitude e Método. Disponível em: http://www.paulofreire.org/Moacir_Gadotti/Artigos/Portugues/Filosofia_da_Educacao /Interdisci_Atitude_Metodo_1999.pdf. Acessado em: 26 jan. 2006.

Goodson, I. A construção social do currículo. Lisboa: Educa, 1997.

Gusdorf, G. Conhecimento interdisciplinar. In: Pombo, Olga (org.). Interdisciplinaridade Antologia. 1 ed. Lisboa: Editora Campo das Letras, 2006.

Gusdorf, G. Para uma pesquisa interdisciplinar. In: Diógenes: antologia. Brasília: Editora da UnB, 1984, v. 7. p. 35.

Heckhausen, H. Disciplina e Interdisciplinaridade. In: Pombo, Olga (Org.) Interdisciplinaridade Antologia. 1 ed. Lisboa: Editora Campos das Letras, 2006.

Juliá, D. Disciplinas escolares: objetivos, ensino e apropriação. In: Lopes, A. C.; Macedo, E. (org.). Disciplinas e integração curricular: história e políticas. Rio de Janeiro: Editora DP\&A, 2002.

Jantasch, A. P. e Bianchetti, L. (Org.). Interdisciplinaridade: para além da filosofia do sujeito. Petrópolis: Editora Vozes, 1995.

Japiassu, H. Interdisciplinaridade e Patologia do Saber. Rio de Janeiro: Editora Imago, 1976.

Llinares, S. Los mapas cognitivos como instrumento para investigar las creencias epistemológicas de los profesores. In: Garcia, C. M. La investigación sobre la formación del profesorado. Métodos de investigación y análisis de dados. Buenos Aires: Cincel, 1992.

Lopes, A.C. Currículo e epistemologia. Rio Grande do Sul: Editora. Editora UNJUÍ, 2007

Lopes, A. C.; Macedo, E. (org.). Disciplinas e integração curricular: história e políticas. Rio de Janeiro: Editora DP\&A, 2002.

Machado, N. J. Epistemologia e didática: as concepções de conhecimento e inteligência e a prática docente. $5^{\text {a }}$ ed. São Paulo: Editora Cortez, 2002.

Machado, N. J. Educação: projetos e valores. São Paulo: Editora Escrituras, 2001. 
Maldaner, O. L. A formação inicial e continuada de professor de química professor/pesquisador. 2 ed.Rio Grande do Sul: Editora UNIJUÍ, 2003.

Maturana, H. R. Emoções e linguagem na educação e na política. 3 ed. Belo Horizonte: UFMG, 2002.

Maturana, H. R.; Varella, F. J. A árvore do conhecimento: as bases biológicas da compreensão humana. São Paulo: Editora Palas Athenas, 2001.

Maturana, H. R. Cognição, Ciência e vida cotidiana. 3 ed. Belo Horizonte: UFMG, 2001.

Mellado, V.; Silva, C.; Ruiz, C. Los Mapas Cognitivos, Elaborados a partir del Cuestinario Inpecip en la Evolución. Editora Pamplona, Spain , 2004.

Mellado, J. V. Concepciones y prácticas de aula de profesores de Ciencias, en Formación Inicial de Primaria y Secundaria. Enseñanza de las Ciencias, 1996.

Moreira, M. A. Pesquisa em ensino: o ver epistemológico. São Paulo: EPU, 1990.

Morin, E. Educação e complexidade: os sete saberes e outros ensaios. São Paulo: Editora Cortez, 2002.

Morin, E. Ciência com consciência. 5 ed. Rio de Janeiro: Editora Bertrand Brasil, 2001.

Morin, E. Os Sete Saberes necessários à Educação do Futuro. São Paulo: Editora Cortez Unesco, 2000.

Morin, E. A educação e a complexidade do ser e do saber. 7 ed. Petrópolis , RJ: Editora Vozes, 1995.

Nóvoa, A. (coord.). Os Professores e a sua Formação. Editora Lisboa: Dom Quixote, 1999.

Padovani, H. e Castagnola, L. História da Filosofia. 7 ed. São Paulo: Editora Melhoramentos, 1967.

Piaget, J. Metodologia das relações interdisciplinares. In: Pombo, Olga (Org.) Interdisciplinaridade Antologia. 1 ed. Lisboa: Editora Campos das Letras, 2006.

Piaget, J. Para onde vai a educação? 6 ed. Rio de Janeiro: Livraria José Olimpio. 1978.

Pombo, O. Contribuição para um vocabulário sobre interdisciplinaridade. Disponível em: < http://www.educ.fc.ul.pt/docentes/opombo/mathesis/vocabulario-interd.pdf> Acesso em: 22 mar. 2006.

Rochberg, F. The Culture of Ancient Science: Some Historical Reflections. ISIS, 1992, 83:547-553. 
Ruiz, C; Silva, C; Porlán, R; Mellado, V. Construcción de Mapas Cognitivos a partir del Cuestinario Inpecip. Revista Electrónica de Enseñanza de las Ciencias. v. 4 n. 1, 2005.

Santomé, J. T. Globalização e interdisciplinaridade: o currículo integrado. Porto Alegre: Editora Artes Médicas Sul Ltda, 1998.

Schön A. D. Educando o profissional reflexivo: um novo design para o ensino e a aprendizagem. Porto Alegre: Editora Artes Médicas Sul, 2000.

Uhlmann, G. W. (2002). Teoria Geral dos Sistemas: Do Atomismo ao Sistemismo (Uma abordagem sintética das principais vertentes desta Proto-Teoria). Disponível em: $<$ http://www.portalga.ea.ufrgs.br/Lauro/teoria_sistemas.pdf.> Acessado em: 13 jun. 2006.

Veiga-Neto, A. Currículo, Disciplina e Interdisciplinaridade. In: Borges, A. S.; Tozzi, A. D. Veiga-Neto, A; Moreira, F. Currículo, conhecimento e sociedade. 3 ed. São Paulo:FDE, 1998.

Wadsworth, B. J. Inteligência e Afetividade da Criança na Teoria de Piaget: fundamentos do construtivismo. 5 ed. São Paulo: Editora Pioneira, 1996.

Youssef, M. P. B e Soncini, I. M. I. PCN Ensino Médio: Aspectos resumidos e comentados. Disponível em:< http://www.scipione.com.br/educa/artigos/artigos.aspx $>$. Acessado em: 05 dez. 2006.

Zabala, A. Enfoque Globalizador e pensamento complexo: uma proposta para o currículo escolar. Porto Alegre: Editora Artmed, 2002.

Zabala, A. A prática educativa: como ensinar. Porto Alegre: Editora Artmed, 1998. 


\section{Apêndice 1}

Questões que perpassaram as nossas “conversas", durante as entrevistas:

1- $\quad$ A concepção de interdisciplinaridade do entrevistado e outras formas de currículo integrado (multidisplinaridade, intradisciplinaridade e transdisciplinaridade).

2- $\quad$ Obstáculos reais que concorrem para a implementação de uma prática interdisciplinar na escola.

3- $\quad$ A proposta interdisciplinar prejudica o desenvolvimento dos conteúdos específicos?

4- $\quad$ Como se deu o contato com a interdisciplinaridade?

5- $\quad$ Existe alguma escola que tem desenvolvido trabalhos interdisciplinares, efetivamente na prática? 


\section{Apêndice 2}

Entrevista: $\mathrm{P}_{1}$

Data: 08/10/2005

Tempo Total: 32 min.

$\mathrm{V}^{26}-\mathrm{P}_{1}$ estou tentando juntamente com a professora Carmen, a gente está tentando buscar uma forma de..., eu não posso dizer que é bem isso, mas seria em parte de entender essa concepção de interdisciplinaridade dos professores de química do Ensino Médio, de química, física, enfim, mas professores do Ensino Médio, se a gente pudesse estender para algumas disciplinas melhor ainda. E o que eu tenho notado é quena literatura, ou lido algumas coisas, recentemente fiz uma disciplina na educação, tentando dar algum norte a essa questão, dessa interdisciplinaridade, você vê algumas coisas, por exemplo, na literatura alguns escritores que falam da interdisciplinaridade da perspectiva do professor, por exemplo, os professores fazendo interdisciplinaridade, aí você vê a interdisciplinaridade a partir do professor e aí você vai aos PCNs, eles falam muito de contextualização e interdisciplinaridade. Então, a nossa idéia é saber primeiro, por exemplo, dos consultores dos PCNs, quando eles escreveram, qual era a idéia, por exemplo, no seu caso, qual a concepção de interdisciplinaridade na época, quando escreveu esses documentos esses parâmetros, não que os professores devem seguir, mas qual era a idéia de interdisciplinaridade que esses consultores tinham, no caso o seu também?

$\mathrm{P}_{1}{ }^{27}$ - Bom, eu vou começar dizendo que não é, tá certo? Em nenhum momento foi pensado em interdisciplinaridade como [e aí fazer uma junção das ciências uma coisa única, uma pasteurização,] (1) vamos dizer assim, das ciências, né. Então, eu acho que isso está bem claro[no documento, que se respeita a disciplinaridade], (2) mas [dentro da disciplinaridade, se procura a questão da interdisciplinaridade,] (3) acho que essa é uma idéia que tem que ficar clara, porque eu penso que isso é um dos pontos mal entendidos, que não é que ele é mal entendido, ele é interpretado de acordo com as conveniências. Então, aonde você não tem muitos professores de química, física e biologia, aliás, de química e física, tem mais de biologia, você pode dar essa interpretação. Ah, então biologia dá química e física.

V - Isso foi uma conversa inclusive, que houve em nível de diretoria, o professor de biologia pudesse substituir, agora acho que abandonaram isso graças a Deus, viram que isso não dava certo, mas a princípio acho que gerou esse mal entendido.

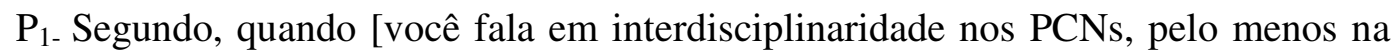
área da química, eu penso que nas da física de maneira geral], (4) está pensado assim, [não é que o seu conteúdo se relacione com outros, na área da química,] (5) eu penso que nas da física de maneira geral,[que a química seja ensinada dentro de uma perspectiva um pouco mais sistêmica, pois ela faz parte de um sistema mais amplo, o mundo físico é uma

\footnotetext{
${ }^{26}$ Refere-se ao entrevistador: Valdir Pedro Berti

${ }^{27}$ Refere-se ao entrevistado: $\mathrm{P}_{1}$
} 
complexidade, é formado de subsistemas que interage,] (6) então quando eu ensino a química e química faz parte da interpretação do mundo físico; então, eu tenho que interpretar no mundo físico, como a química, mas eu posso utilizar outras ferramentas, [a química não está isolada dos outros subsistemas,] (7) então é nesta perspectiva que a gente tenta a interdisciplinaridade.

$\mathrm{V}$ - Por exemplo, $\mathrm{P}_{1}$, sempre quando eu vou pegar um assunto, eu vou discutir os conceitos de química e aí eu convido outras áreas a trabalhar sobre essa perspectiva de um tema, de um objeto, enfim seria isso? É a contribuição?

$\mathrm{P}_{1}$ - [Ou você convida ou você próprio faria isso,] (8) se você, eu vou dar um exemplo que está no PCN da metalurgia, então como é que está lá, o que sugere os PCNs, metalurgia, mineração e metalurgia do ferro no Brasil, então isso aqui focaliza a química mas é mais amplo do que a química, não é? Você está vendo o contexto social brasileiro, que normalmente fala alguma coisa disso, é o professor de geografia ou está lá no livro de geografia, mas está na mídia também, então o professor de química, pode, ele não precisa pedir para o professor de geografia dar um texto, você pode pedir para ele te dar um textinho e você, algo que você com alguma cultura tem que ter e a partir disso você vai estudar o que acontece no auto-formo etc, numa linguagem química etc, você vai, por exemplo, estudar um boletim de produção, compreender as dados quantitativos etc, e até no boletim de produção você vai entender de rendimento, rendimento já tem que ver com a economia, os problemas de enferrujamento, então com tudo isso você está desenvolvendo a química, mas está sempre ligando um pouquinho.

\section{$\mathrm{V}$ - Nesse contexto social?}

$\mathrm{P}_{1}$ - Exatamente, as implicações sociais ambientais e políticas, então quando você vai discutir, sei lá, a questão produção, produz dessa forma, o minério vem de onde? Mas, como é que é essa exploração do minério? O Brasil faz o que com esse minério produzido, utiliza para, agregar valores, não agrega valores, importa, exporta matéria-prima, ou já com valor agregado, etc. Então, e aí o aluno pode ser, tem essa colcha eu acho que isso está certo, acho que isso está errado, ou a produção se não cuidar vai acabar o ferro, ou não, então ele tem noção de quanto que, não é só a reação do auto-forno.

V - Eu sei, ele não só ficaria na reação química.

$\mathrm{P}_{1}$ - Não, é só entender o processo da forma energética etc. e quimicamente, mas ele vê quanto tem de, quanto é a jazida de ferro no Brasil, da onde vem e a condução do ferro. Polui ou não polui? É bom, ou não é bom ?

$$
\begin{aligned}
& \mathrm{V}-\mathrm{O} \text { quanto isso afeta o ambiente? } \\
& \mathrm{P}_{1} \text { - Então, eu acho que é isso. } \\
& \mathrm{V} \text { - Quanto isso trás de riqueza para o país? }
\end{aligned}
$$


$\mathrm{P}_{1^{-}}$Isso, pode até ampliar né; então, [eu acho que essa a idéia de interdisciplinaridade que a gente tinha em mente a hora que produziu esses parâmetros, e esse exemplo eu peguei de lá.] (9)

Na química fala, num segundo, momento onde o conteúdo é visto na [“Interação do Indivíduo com o Meio" o que o homem extraiu do seu mundo, o que ele criou, modificou, o que ele voltou a por no ambiente.] (10) Então, dentro dessa visão, por exemplo, um químico falar no ciclo bio-geo-químico, parece natural a questão do carbono, o ciclo do $\mathrm{CO}_{2}$, que normalmente é o biólogo que faz, então se você naquele momento você pedir para o professor de biologia discutir junto com você está ótimo, mas não foi nem pensado só assim, não é, e você professor de química tem que ter condições, de discutir o ciclo do carbono, não é?

V - Não é avançar na área do professor, mas é pegar o que está aí e ir um pouco além.

$\mathrm{P}_{1}$ - [Dar uma visão um pouquinho mais ampliada da química,] (11) ou qual que é a relação da química com a sociedade, a química com o sistema produtivo, a química com o ambiente, para aluno contextualizar, [para ele poder entender, para ele poder tomar uma posição, essa é a idéia.] (12)

V - Então, nessa perspectiva, quer dizer é o professor de química, ele tem o conhecimento de química, claro que ele não vai avançar, por exemplo, extremamente no conhecimento das outras disciplinas, mas é como se ele fizesse assim, estudasse algumas coisas das outras disciplinas que foi inserido no contexto?

$\mathrm{P}_{1}$ - Tem que pensar a intersecção da química, nessa intersecção, a relação da química com os outros subsistemas, às vezes, esses subsistemas também são representados escolarmente por disciplinas. Nessas disciplinas como é que eu poso fazer essas pontes.

$\mathrm{V}$ - E se ele puder em alguns momentos conversar com os professores, se for possível também?

$\mathrm{P}_{1}$ - Se você imagina o professor de geografia discutindo lá essa questão do solo brasileiro, não sei o que e ele vai falar das jazidas, de repente ele fala, puxa!, professor explica aí como é que é produzido o ferro, como é que esse negócio do auto-forno, ou você não quer na sua próxima aula de química ligar e falar isso; então você vai lá e fala, olha vocês estão estudando isso, ferro é produzido dessa maneira, energia induzida, tem um custo, não tem um custo, isso não está nos PCNs, mas eu estou imaginando, não é? Quer dizer que se cada professor tem essa perspectiva é possível nas HTPCs haver uma troca e um colaborar com o outro. Sem ter aquela necessidade de todo mundo dar tudo ao mesmo tempo.

$\mathrm{V}-\mathrm{Eu}$ sei, aqueles projetos todos que praticamente inviabiliza qualquer proposta?

$\mathrm{P}_{1^{-}}$Você pode até chegar lá, como faz a Escola da Ponte, lá de Portugal, porque agora todo mundo só fala nessa Escola da Ponte. 
V - Mas ela foi preparada, com toda a estrutura para isso.

$\mathrm{P}_{1}$ - É desde a pré-escola, e não tem Ensino Médio.

V - Então, mais ou menos assim, se o professor tem condições de fazer esse contato com os professores, ótimo e tal.

$\mathrm{P}_{1}$ - Então, isso faz bem até para ele, me ajudem, me instrumentalizem, me indiquem uma leitura, não sei o quê, não que ele vai ter que ser uma colcha de retalhos, não sei o quê, mas nessa perspectiva de [dar uma visão um pouco mais contextuada, mais ampla para o aluno,] (13) não é, o que eu tenho que colocar lá, sem perder o foco do ensino de química, porque, às vezes, a gente vê propostas de se trabalhar com temas interdisciplinares que começam assim, fala tudo da metalogia, o ferro é produzido assim, o cobre, pá, pá, pá e não sai disso, não é? Então, nem aprofunda a química e nem aprofunda o social, fica só no informativo.

V- Essa é a crítica que se faz à pedagogia de projetos, é a superficialização ou a banalização dos conteúdos.

$\mathrm{P}_{1}$ - Porque, você não precisa do conhecimento específico, você fica na coisa do senso comum para responder.

V- O interessante é fazer essa ponte, sair para o contexto geral e se enraizar bem ao conteúdo, se professor puder fazer com os colegas ajudando, ótimo, senão ele procura essa fala de fazer sozinho de caminhar nessa interdisciplinaridade, seria assim?

V- Você acha que alguma escola tem feito esse trabalho interdisciplinar? Dentro da nossa realidade? Com o número de aula que os professores têm, dando aulas em várias escolas é possível fazer esse trabalho?

$\mathrm{P}_{1^{-}}$Olha, nós temos uma professora aqui, que diz que usa projetos, nas aulas de química dela. São só "projetinhos", que ela procura fazer um pouco nesse caminho. Nós tivemos experiência com professores, e os professores criaram, de química, criaram seus projetos com essa visão. Ah, eu vou ensinar química, mas eu vou, um exemplo o álcool, né tem um problema com o nível de alcoolismo, essas coisas. Então, teve um grupinho que colocou lá a questão, mas, discute como o álcool é produzido, como o álcool é utilizado, quais os problemas do álcool no organismo, quer dizer, ensina química, a fermentação, como você isola, métodos de separação, destilação, álcool como combustível, o que acontece, álcool no organismo. Ensina alguns processos e o aluno depois é convidado a refletir sobre a questão de beber ou não.

$\mathrm{V}$ - Me parece $\mathrm{P}_{1}$, eu não sei, mas eu tenho a idéia assim, eu não pesquisei. Mas.

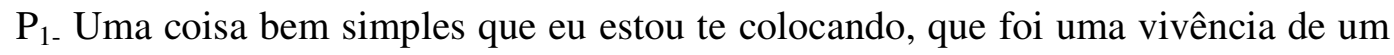
professor aqui. 
V- Então, dentro desta vivência, o que eu tenho percebido, me parece, que pelo atual contexto da escola que agente vive e número de aulas que o professor dá , esta é a mais possível, do professor fazer a interdisciplinaridade?

$\mathrm{P}_{1}$ - Eu não acho que é só o números de aula não, sabe eu acho que tem uma série de variáveis aí, o professor precisa ter formação continuada, nós tivemos uma experiência de formação continuada que nos mostrou muito a importância do mediador da figura de uma pessoa um pouco acima de conhecimento, de reflexões que os ajudasse a refletir, a propor, a implementar em sala de aula.

$\mathrm{V}$ - Eu acho que sozinho o professor não consegue fazer isso sem ajuda dessa pessoa.

$\mathrm{P}_{1}$ - É nesse ponto ficou muito claro, como foi importante, como seria importante ter um mecanismo desse tipo de coisas, eu não sei se na Diretoria de Ensino, aquele grupo de professor que quisesse continuar estudar, propor que tivesse um apoio, porque eu acho que primeiro, mesmo que ele tenha tempo e não tiver assim um ponto de apoio, ajuda não é uma boa palavra mas, alguém que oriente um pouco, eu acho que não funciona; alguns funcionariam, alguns acham que sim.

V- Mas no geral a educação tem mostrado que não funciona.

$\mathrm{P}_{1}$ - Às vezes, o professor não tem muita formação e não sabe buscar informação, ou na rede ou no jornal, ou num livro que não está acostumado a freqüentar biblioteca não é?

V- Às vezes, ele não consegue avançar justamente porque estas coisas dão para ele uma insegurança muito grande, eu acho que é imprescindível entre universidade e professor. Agora, quando se fala em interdisciplinaridade, eu vejo assim, a própria palavra diz entre disciplinas, você pode fazer isso conservando a disciplinaridade, e quando se fala em transdisciplinaridade o que eles querem dizer com isso?

$\mathrm{P}_{1^{-}}$[A trans você não tem mais as disciplinas que se reúnem para resolver um problema ou pra desenvolver um projeto.] (14)

V: Mas, aquele problema não teria novamente a disciplina ali?

E- Então, você usa o suporte da disciplina o conhecimento, mas o ensino seria transdisciplinar, hoje [não é aula de química, aula de química vai aparecer quando for necessário para informações para resolver um problema.]

V - Entendi, é como se você tivesse uma situação na sociedade, eu quero analisar aquela situação, dependendo do momento e da necessidade o professor de química contribui, ou num outro momento o professor de física, é por isso que se fala além de, esse trans seria além das disciplinas é isso?

$\mathrm{P}_{1}$ - Imagine assim, que você, eu li isso num outro dia eu não sei onde, vai ser implantada uma hidrelétrica na cidade; então, imagine que você vai tornar isso um 
conteúdo escolar, que disciplinas vão entrar ai, vão discutir se é vantagem se é desvantagem nossa cidade possuir uma usina de geração de energia elétrica. Bom primeiro tem que entender como é que isso funciona, eu preciso do físico, da geografia não sei o que, bom funciona assim, e um impacto ambiental preciso a ecologia, preciso da química, historicamente não tem outra forma de gerar energia entendeu? Para resolver um problema não ficar na superficialidade, eu vou entender o que é energia, como gerar a energia, então eu preciso daqueles conhecimentos de física, ai o aluno eu não sei quem lá, é melhor uma usina termoelétrica, do que acabar com o rio, acabar com isso, trá, lá lá lá. Vamos supor, isso seria numa abordagem um pouco mais disciplinar não é totalmente mais a idéia é essa, ou vamos supor que o tema é ética, o tema desse bimestre ou desse semestre, ética nas relações sociais, eu não sei como é que a química entra aí, mas enfim no momento que é isso, o que não é, eu posso jogar o lixo, ou o quanto de lixo eu posso por na rua ou qual é a minha preocupação com a reciclagem do lixo não, sei o que, tem comportamento nhenhenheeem, ai você vai gerar um conhecimento especifico, é uma questão diferente [você tem que estar lá de plantão porque foge da disciplina.] (16)

V- O professor teria que estar disponível a essas situações, ou seja, estar na escola o tempo todo.

$\mathrm{P}_{1}$ - É você tem que organizar de outra forma, não você pode até planejar, o projeto vai nessa linha; aqui é bom ter essa aula, aqui é bom ter essa aula, mas já é um outro tipo de planejamento que foge bastante do convencional, e também não se trata de fazer a interdisciplinaridade uma coisa muito disciplinar, por exemplo, o tema do nosso bimestre é água, o químico ensino água, o físico ensina água, o geógrafo ensina água, o inglês ensina água, mas cada um na sua, você não dá um todo para aquele tema a água, isso é um abordagem multi. quiser.

V- Mas todo mundo falando de água, mas dentro da sua disciplina mais como ele

$\mathrm{P}_{1^{-}}$[É mas, cada um na sua, sem ter relações,] (17) até pode acontecer que tem, [mas sem ter relações,] (18) diferente da inter, quer dizer, você químico vai trabalhar água, você não vai falar só das soluções, não sei o que, o que acontece, quais os problemas das soluções, o que é água pura, o que acontece, vai para poluição, vai para necessidade de água no planeta, do uso racional, ou não sei lá o que.

V - Se o ciclo de água vai acabar se a quantidade de água no planeta é a mesma.

$\mathrm{P}_{1}$ - Então, você faz uma abordagem que dá uma visão mais ampla mais sistêmica, você agrega na química outros conhecimentos que no texto não teve, processo que torna mais fácil o aluno ler no mundo, ele olha no rio e não imagina que aquilo é uma solução, que aquilo tem oxigênio dissolvido, que o problema da morte de um rio está relacionado com oxigênio, com esgoto, sabe não há essa correlação.

$\mathrm{V}$ - $\mathrm{P}_{1}$, o que se busca com tudo isso, é dar significado ao conhecimento, essa é a idéia, por exemplo, no fundo, no fundo, o que eu penso em fazer com isso, por exemplo, o aluno ele viu ali, ele não faz essas relações, ele não percebe que o oxigênio está dissolvido; 
enfim, o que se pretende com essas tentativas é dar maior significado ao que se estuda; essa é a idéia?

$\mathrm{P}_{1}$ - Eu acho que não é só isso, tem gente que fala sentido e significado, o aluno tem que entender aquilo, aquilo faz sentido para vida dele, porque que estou estudando água, o que eu sei de água, o que eu sei e porque que eu estou estudando isso, que sentido tem isso para mim, não é? Acho que além disso é dar oportunidades para que aluno interprete melhor, possa tomar as suas decisões baseadas no conhecimento, não só em comportamentos. Ter uma atitude não só baseada no comportamento, e numa atitude qualquer não só no comportamento, baseada também no conhecimento, que não precisa ser só químico, que ele possa integrar um pouco.

V- E se eu pensar no ponto de vista do currículo do Brasil, historicamente ele foi pensado para ter uma disciplina.

$\mathrm{P}_{1^{-}} \mathrm{O}$ currículo no Ensino Médio não era para, o Ensino Médio era propedêutico, não é, era pra uma preparatória para universidade e foi perdendo esse caráter com a Lei 5.692, que profissionalizou todo mundo e que voltou a trás e com a LDB perde totalmente esse caráter, quer dizer, não perde totalmente esse caráter, para preparar para estudos futuros mas prepara também para o mundo do trabalho, preparar também pra vida, subjetivo, né?

$\mathrm{V}$ - $\mathrm{P}_{1}$, obrigado por sua disponibilidade, nossa conversa foi muito esclarecedora. 
Entrevista: $\mathrm{P}_{2}$

Data: 01/12/2005

Tempo Total: $26 \mathrm{~min}$.

$\mathrm{V}^{28}-\mathrm{P}_{2}$, Como tem sido o seu trabalho?

$\mathrm{P}_{2}{ }^{29}$ - Bom, eu trabalho com formação de professores e trabalho em pesquisa em escolas em que os professores buscam seguir compreensões que a gente produz coletivamente e em interação com eles, esses então são os meus trabalhos, nesses dois campos. Agora quando a gente faz isso, obviamente a gente tem uma posição que eu chamo de assimétrica, pelo fato de trabalhar com formação de professores em universidades, embora eu tenha sido integrante do Ensino Médio durante vinte e cinco anos.

V - Já passou por isso.

$\mathrm{P}_{2}$ - Isto, já passei e conheço todos os caminhos das pedras e as dificuldades.

Então, é mais ou menos assim, como essas pessoas com quem eu trabalho são da região e reconhece a gente como alguém que forma professores, ou seja, alguém que tem uma opinião que eles buscam compreender e, às vezes, confrontar e seguir, às vezes, entender e tentar seguir, então esse é o lugar que eu falo para você.

\section{V - Esse espaço em que você está atuando?}

$\mathrm{P}_{2^{-}}$Exatamente, então o que nós temos desenvolvido é fundamentalmente na matéria química, nós estamos falando de Ensino Médio, né? São dois casos, um caminho é mais do que fazer o que a gente tem preferência é de fato compreender o Ensino Médio como Educação Básica, [o que não está dado, porque o Ensino Médio é compreendido como (1) um conhecimento propedêutico], ou seja, de transição para a universidade, mesmo que muitos não continuem, mas essa é a expectativa social das pessoas dos pais dos estudantes e isso é mais forte ainda quando a escola é particular, pelo fato de ser um curso preparatório e aí não importa se aquilo que foi ensinado é importante ou não, o que eles querem é passar para a universidade, o que é justo, é a expectativa social, mas a gente está trabalhando realmente na perspectiva daquilo que o Brasil quer, um Ensino Médio que seja de [Educação Básica, compreende o que o brasileiro precisa saber para ser considerado uma (2) pessoa participante enquanto cidadão, cidadão em todas as facetas] em que ele é chamado; então, essa é a idéia, ao fazer isso os documentos oficiais vão e indicam em primeiro lugar as escolas têm autonomia em definir o que aquela comunidade escolar quer da sua escola pela definição do projeto político pedagógico, ou seja, não existe nenhum modelo, não existe nenhuma obrigatoriedade, a não ser um núcleo comum nacional, que é uma definição meio difusa, básico comum nacional não existe conteúdos nenhuma área para dizer o que é esse núcleo básico, mas existem núcleos básicos de disciplinas que tem que ser dado nas escolas do Ensino Médio, ou seja, física, química, agora então as escolas precisam definir realmente o que fazer tendo uma liberdade grande para fazer isso, a gente

\footnotetext{
${ }^{28}$ Refere-se ao entrevistador: Valdir Pedro Berti

${ }^{29}$ Refere-se ao entrevistado: $\mathrm{P}_{2}$
} 
procura cada caso a decisão dos professores, ela não parte de definições externas aquilo que eles poderiam fazer dentro daquela própria escola, então é um passo fundamental. Bom, ao fazer isto um outro documento define bem às [Ciências da Natureza, Matemática e suas Tecnologias é uma área;] (3) então, tem que ser compreendido como uma área, mas [sem perder a característica disciplinar, existe de fato o campo disciplinar de física, química, biologia e matemática,] (4) mas ela deve ser compreendida como uma área que tem objetos do mundo natural ou do mundo das tecnologias, ou das modificações que os seres humanos produziram em comuns, quer dizer, ou seja, eles têm um campo que se aproximam de alguma forma. Bom, como é que a gente vai fazer isso numa escola de tal forma que esse núcleo, essa área de conhecimento permite tomar um pensamento, não é? Que seja realmente capaz de abarcar, abranger os objetos reais desse mundo, eu chamo de "Objetos de Investigação" ("OI”) que são as tecnologias, que são os fenômenos naturais, fenômenos artificiais, que são as ciências humanas ligadas com a materialidade, que o ser humano lida, você veja que Ciências da Natureza e suas Tecnologias significa que eu não vou estudar as relações humanas, isso é outra área do conhecimento, eu não vou estudar as relações de organização social isso é outra área, eu vou estudar as Ciências da Natureza e para isso [eu preciso da Física, da Química, da Geologia, da Matemática, para compreender esse conjunto enorme, Astronomia e assim por diante.] (5) Então, para que isso seja possível [eu preciso fazer que haja interlocução entre esses campos,] (6) [e essa interlocução não se dá na cabeça das pessoas de forma natural,] (7) precisa ser ensinada. Essa interlocução é uma visão complexa, portanto, de desenvolvimento mental superior que precisa ser criada, nós não temos uma visão complexa por natureza, o ser humano lida com capacidades complexas, ou seja, de múltiplas dimensões, olhar ao mesmo tempo muitas definições, porque ele aprendeu então se constitui que sua mente foi fundada nisso.

$\mathrm{V}$ - Esperar que o aluno faça é isso que o professor quer ver, ou seja, transferir essa responsabilidade para o aluno é algo, não é possível?

$\mathrm{P}_{2}$ - Não, não é possível, claro, porque ele [vai ficar em disciplinas separadas] (8) por mais que você ensine aquela pessoa; você precisa partir de uma perspectiva que isso é comum, então essa perspectiva comum é a gente chama de "OI", ou seja, nós vamos estudar uma [“OI"] (9) ao mesmo tempo pelos campos disciplinares diferentes, nós estamos fazendo experiências que já são suficientementes complexas para gente poder ter uma visão boa, usando a química, a física e a biologia, alguma coisa em matemática, mas seria um outro papo né. A matemática eu viria como dois campos bastante diferentes, um seria objeto das relações matemáticas, o outro seria a matemática como uma ferramenta, um instrumento importante, no que pese para os diversos campos disciplinares, nas ciências naturais como a química, física etc.

\section{V- Dando um aporte?}

$\mathrm{P}_{2}$ - Isso exatamente, então é essa parte da matemática, também que a gente tem alguma experiência, mas o que realmente a gente está estudando, está conseguindo abarcar é a "OI" do ponto de vista da Física, Química e Biologia. Bom, então a gente define essa "OI", que é uma situação que tem certas características, não é qualquer situação, vamos escolher essa situação, em muitos debates, com critérios, por exemplo, se isso é para a formação mais inicial, se é para uma formação mais intermediária, ou mais final. Então, a 
gente escolhe a situação que serve melhor para que os conhecimentos da área sejam trazidos para dentro dessa situação, então o ensino passa a ser praticado com algumas idéias fortes que são centrais em cada uma das disciplinas. Os professores começam a pensar aqueles recortes do mundo, né que eu chamo de "OI" e começam a estudar aquilo, ou pelo ponto de vista Física, da Química ou da Biologia e fazendo as interconexões. [As interconexões que elas são buscadas pelos próprios professores, nem sempre eles as enxergam, mas no debate que eles fazem entre si, eles começam a enxergar,] (11) mas principalmente o aluno, aí sim ele consegue perceber, porque ele está estudando ao mesmo tempo dentro da escala, dentro da abordagem das três disciplinas, uma determinada coisa, então eu vou dar, por exemplo, a "OI 1", é uma das situações. Bom, fazer esse estudo da "OI 1" é óbvio que a química vai mostrar que a gente estuda é a química que funciona na interação das substâncias em um meio aquoso, por exemplo, e esse meio aquoso permite contato com a substância, permite com que elas se tornem ativas, na forma interativa, ela permite como meio, portanto a modificação dessa substância, exatamente aquilo que a biologia precisa, ou seja, a biologia precisa com que a questão vida que se desenvolve no meio aquoso, ela permite a migração de substâncias, permite a solubilidade, permite as trocas para, por exemplo, manter a célula viva, ou manter a relação entre células que compõem um órgão, ou organismo, né? $\mathrm{E}$ ao mesmo tempo a física vai estudar questões, como pressão causada por ações de descargas elétricas sobre membranas, comportamento de tensões superficiais, coisas que dizem respeito a essa mesma questão, então os conceitos centrais de cada uma das disciplinas fica definido, só que para você mexer com esses conceitos centrais, você precisa trazer alguns dos conteúdos, por exemplo, eu preciso trabalhar em química, vamos falar mais em química, que eu domino, é meu campo. Então, a química obviamente vai tratar, no caso, de interações intermoleculares, vai tratar das estruturas moleculares como é que elas são, o que significa a presença de metal na estrutura dessa substância, este metal, ele tem um comportamento de que associação, como cátion, ou ele participa do ânion, onde existe, então, a boa possibilidade de interação da água, que caracterizas especial tem a água do ponto de vista químico que ela consegue fazer com que as substâncias interagem em principio, quer dizer, eu vou trazendo para a Àgua e Vida que é o tema da discussão, o contexto dos conhecimentos químicos, que ele precisa para entender bem o que é aquela situação especial que permite a vida. E que sem ela nós não poderemos ter a vida que nós temos, é assim que nós fazemos a interlocução, é óbvio se eu vou, por exemplo, modificar a tensão superficial da água, digamos por um detergente a química vai dar uma boa resposta, mas ao mesmo tempo a física vai mostrar o que é essa tensão superficial, quer dizer, como é que ela é, que valores ela tem, o que significa isso sob o ponto de vista da capilaridade, do ponto de vista de você poder circular uma substância, um ser vivo como uma árvore, por exemplo, ou um peixe, quer dizer, o que significa a pressão alta para um ser vivo, nas profundezas marítimas, por exemplo, ou o que acontece se há uma descompressão rápida, dos corpos humanos, digamos na área, porque também falamos da área ecológica; então, como é que, por exemplo, o significa, [um mergulho nas águas profundas de um ser que tenha um pulmão como reservatório de ar, aí a solubilidade dos gases, quer dizer, tem todos esses conteúdos que trás para dentro do contexto rompendo completamente com a forma tradicional.] (12)

V - Disciplinar de cada um transmitindo o seu conhecimento? 
$\mathrm{P}_{2^{-}}$Exatamente e isto é todo o currículo, que dizer não é um projeto paralelo, digamos eu vou continuar ensinando minha química, minha física, minha biologia, não [eu rompo completamente com uma estrutura curricular aquilo que é tacitamente aceito] (13) como sistema a ser ensinado para começar a dizer com que conhecimentos químicos, físicos e biológicos, eu preciso para compreender uma complexidade como é, por exemplo, a "OI 1". Essa relação que existe e tenho aí surpresas, por exemplo, começo a ter necessidade de conhecimentos atuais, começo a ter necessidade de compreensões de soluções tecnológicas, começo a ter necessidade de outros conteúdos que jamais se pensava que podia ser ensinado no Ensino Médio, então você cria realmente uma nova lógica curricular. É assim que nós trabalhamos.

$\mathrm{V}$ - O professor vai ter que se atualizar, ele vai ter que ler, ele vai ter que se inteirar, para dar conta dessa aula que é uma contextualização de uma situação e é claro que eu vejo como maior envolvimento dos alunos, agora.

$\mathrm{P}_{2^{-}}$Deixa eu só dizer uma coisa aqui, o interessante como hoje existe muita informação disponível, o professor realmente incentiva dentro da necessidade de um novo conteúdo, de um novo conhecimento, que surge porque os alunos vão fazer muitas perguntas, o professor sempre tem chance de examinar as ditas fontes, então os alunos conseguem hoje trazer muitas coisas para a sala de aula, seja em revista de educação científica, seja na internet, que é a fonte que eles mais consultam. A internet deixa de ser, agora vocês tem tal assunto que vocês pesquisam e me entregam, não, você traz os assuntos que eles acham na internet e joga eles no didático; aquela pesquisa que não leva a nada e que o aluno simplesmente entrega para o professor como uma tarefa, ela passa a ser importante para a aula seguinte.

V- Entendi, ela passa a ser uma estratégia, ou seja, você pode usar aquilo para fomentar a discussão e o interesse.

$\mathrm{P}_{2^{-}} \mathrm{O}$ interesse e os alunos realmente aprendem a lidar com informações, selecionar informações, porque, aí de repente você percebe que na aula aquela informação que ele trouxe com tanto empenho, não, serviu para nada; ele percebe que ele deveria ter selecionado melhor, então são vários, ou a informação serve, desde de que a gente consiga perceber onde ela se encaixa, são várias coisas disponíveis.

$\mathrm{V}$ - Deixe-me ver se eu estou entendo, um professor pega um tema como esse, uma "OI", é estudado entre professores, digamos que, o professor trabalha com formação de professores, ele vai para a sala de aula deve estar acontecendo, ele vai colocar esses assuntos. Acho que tem um momento de discussão antes entre eles sobre o que trabalhar e depois eles vão para a sala de aula desenvolvendo as disciplinas, é isso?

$\mathrm{P}_{2}$ - Vão desenvolver aquela situação, cada um com seu campo disciplinar, que eles tem que, porque eu estou falando da primeira linha que é a mais complicada que é essa, eles vão realmente decididos, e abrem o jogo para os estudantes, nós vamos agora estudar a área das Ciências da Natureza, nós vamos estudar esse assunto digamos "OI1", nós temos vários, "OI 2", "OI 3", que são três circunstâncias que a gente estuda no primeiro ano, isso comporta todo o primeiro ano. Então, em dois meses ou três os alunos produzem eles fazem 
avaliações também em comum, os professores analisam essas avaliações sobre o ponto de vista da compreensão total e sobre o ponto de vista de uso de cada componente disciplinar, o aluno terá uma avaliação pela compreensão da situação como um todo e especificamente com os conceitos da química, da física e da biologia. Na verdade para cada aluno são dadas duas atribuições de valores, de avaliação, em que ele se aplica como um todo, ele tem nove, mas ele de fato usou essa compreensão, mas foi muito deficiente com compreensões incorretas em física, então em física ele tem muito menos valor, mas a atribuição da avaliação dele vai ser digamos se for em nota, a nota vai ser o coletivo e mais aquela disciplina de física, digamos que a física aí tem muitos erros conceituais que não atrapalharam totalmente a compreensão, mas na física deu problema, ele não teve uma boa concepção de energia, vamos supor então ele vai ter uma nota mais baixa, mas no fundo ela vai ter um ajuste para que mostre que foi importante para que se possa compreender aquela situação como um todo, então eles decidem coletivamente antes e identificam alguns tópicos centrais, mas no desenrolar da situação vai gerar tópicos que não se esperava, então eles têm que constantemente se reunirem diante disso, mas necessariamente eles devem terminar essa situação num bimestre, ou num trimestre, depende como a escola é organizada.

V- Agora aí se resolve um problema que é uma crítica que se faz, em nível de Ensino Médio que é o professor não avaliar a parte conceitual, não é?

$\mathrm{P}_{2^{-}} \mathrm{O}$ aluno tem uma avaliação, eu diária assim, mais macro em cima do tema e depois dentro da especificidade, e o interessante que eles saibam, essas experiências são mais recentes, mas elas funcionam bem e deixam os professores muito satisfeitos, porque ganha tempo, porque as avaliações você sabe com são nas escolas, é uma semana de preparação, outra semana de correção e mais uma semana de, que eles dizem que agora eu estou cheio de prova e não quero nada, ou seja, você perde praticamente três semanas; nessa forma não existe esse problema, porque é uma decorrência normal do trabalho é feito uma avaliação coletiva e que o tempo para isso passa ser muito menos importante e sim o importante não é a sistematização de física, mas sim a sistematização que está acontecendo durante todo o processo e aí o professor tem uma boa percepção do que ainda ele não domina.

V- E essa avaliação professor, macro, quer dizer, essa avaliação maior é produzida pelos professores?

$\mathrm{P}_{2}$ - Pelos professores.

\section{V- Eles produzem uma avaliação?}

$\mathrm{P}_{2^{-}}$Isso, com questões que permitem ao aluno usar os conceitos da física, da biologia e da química e eles vão olhar com muito acuidade o nível de compreensão e de construção que eles já tem desses conceitos, com o trabalho eles avaliam positivamente o que eles já conseguiram fazer e obviamente esse positivo tem uma graduação, e não pelo que eles não fizeram, já conseguiram fazer esse conceito até aqui. Ele é avaliado por isso.

$\mathrm{V}$ - $\mathrm{P}_{2}$, porque transdisciplinar, como há essa diferença que você faz entre, por 
exemplo, o inter e o trans? Porque eu estou enxergando assim, tem momentos de disciplinaridade aí. E como você define essa diferença?

$\mathrm{P}_{2}$ - Isso é muito importante, o interdisciplinar, cada mantém a sua disciplina, ela é uma ponte, porque você entender [uma situação entre as diversas disciplinas,] (14) quer dizer, [como é que a minha disciplina está ajudando na compreensão disso,] (15) então isso a gente chama de interdisciplinar, mas quando eu passo para o transdisciplinar, eu transgrido, por exemplo, na minha aula de química, eu preciso que ele perceba isso do ponto de vista da biologia, é muito importante as conexões, como é que vocês percebem, por exemplo, se eu estou falando em vida, vamos pegar osmose, vocês trabalham na biologia osmose, ótimo, então como é que vocês estão vendo a osmose como um fenômeno na biologia, aí eles começam a perceber que aquele conceito na biologia tem um sentido um pouco diferente, aí os professores começam a mostrar, bom essa conexão, o que é a osmose química, realmente, ela é um fluxo de solvente, senão não é osmose, em química nós chamamos de osmose a membrana que permite a passagem de solvente entre soluções de concentrações diferentes, agora em biologia você também tem trânsito de substâncias. Bom, é necessário e como é que se chama isso? Ah, bom, isso daí já não é mais osmose, isso aí nós chamamos, aí eles vão trazendo os termos, ou seja, as conexões são buscadas intencionalmente, então a gente diz transgride as disciplinas, isso nós chamamos de transdisciplinar, ao invés de eu defender a minha disciplina, eu transgrido, o campo que elas definem e aí eu digo, bom essa necessidade de se pensar nisto, dessa forma do ponto de vista da biologia, ou do ponto de vista da física e tem coisas interessantes, por exemplo, o biólogo ele tem uma compreensão de elementos diferente do químico, para o biólogo, elemento significa qualquer coisa que diz respeito da natureza de uma substância, [ele não tem nenhum cuidado de dizer assim, como o químico precisa formar o conceito de elemento como constituinte da substância, quando o químico fala, o elemento ferro é ele sabe que ele vai constituir a substância elementar ferro, ou vai constituir a substâncias compostas que tem ferro, bom para o biólogo interessa o que tiver no composto, não interessa esse elemento, às vezes, ele fala em elemento também para a glicose, fala de elemento, ele não tem esse cuidado.] (16) [No transdisciplinar você começa a mostrar as diferenças de uso da linguagem entre uma área de conhecimento e outra] (17) e isso dá um debate interessante, porque os alunos começam a ficar na dúvida na hora que o professor de biologia fala em elemento, mas eles querem saber, mas é elemento, como é que você está falando de elemento, se você fala glicose, se nós sabemos que a glicose tem três elementos, nós temos o carbono, hidrogênio e oxigênio e você está falando como elemento, ele começa a transgredir essas coisas.

\section{V- È neste sentido?}

$\mathrm{P}_{2 \text { - }}$ [É neste sentido das interconexões, quer dizer, você começa a olhar mais que uma dimensão, começa olhar para as dimensões,] (18) [você interconecta ação disciplinares,] (19) neste sentido, ao invés ficar defendendo, a sua disciplina, o Morin diz que o interdisciplinar parece uma reunião da ONU, cada um defende as fronteiras do seu país, mas também pode ser um avanço, se eles olham o conjunto; agora se for, por exemplo, [o interdisciplinar cada um defendendo a fronteira do seu país,] (20) ela não tem um grande avanço, mas é melhor do que simplesmente desconhecer que existe outras disciplinas, não é? É melhor saber que existe a ONU do que desconhecer, né? Agora, se eu ficar apenas 
defendendo minhas idéias, meu limite territorial e vou esquecer, mas não eu tenho que cuidar, se eu, por exemplo, defendo que a água é um bem da humanidade é diferente de eu dizer assim, a água é minha e eu só vou vender se você me pagar em preço, quer dizer, é diferente, o petróleo é nosso e nós botamos o preço que nós queremos, isso é a ONU da defesa do seu território. Agora, não mas o petróleo é uma necessidade da humanidade é um bem da humanidade, e nós temos que não inviabilizar a economia mundial, temos que ver o que é necessário produzir mais, ou vamos criar a escassez para fazer a exploração, quer dizer, isso também acontece agora; [o transdisciplinar ele olha as questões de uma forma um pouquinho mais ampla do que seu campo disciplinar,] (21) [mas ele tem o compromisso com a sua disciplina ] (22)

V- Quer dizer, é sempre um ir e voltar.

$\mathrm{P}_{2^{-}}$Isto, eu quero que o químico, ou o físico me dê uma boa explicação para tensão superficial para que eu na química possa discutir, porque que o detergente tem essa ação drástica na tensão superficial, da água, por exemplo, e o que significa quebrar a tensão superficial para a vida aquática, por exemplo, já que a "OI 1", [então eu preciso que o físico tenha feito um bom trabalho disciplinar e que o químico tenha feito um bom trabalho disciplinar e que o biólogo tenha feito um bom trabalho disciplinar] (23) para que daí a compreensão do todo possa se dar; é nesse sentido que a gente chama de transdisciplinar.

V- transgredindo aí.

$\mathrm{P}_{2^{-}}$Transgredindo. Agora essa seria a forma mais complexa, mas se a gente quer falar de química, eu tenho uma outra possibilidade, você quer que fale disso?

V-Claro pode ser.

$\mathrm{P}_{2}$ - Então, o seguinte como na formação de professores, eu tenho consciência que ele vai cair numa arena de luta, em que esse professor novo, principalmente, ele não tem nem chance de discutir com o professor de física, de biologia para melhorar e começar seu trabalho; eu na formação de professores tenho que prepará-lo para ele [dentro da própria disciplina de química] (24) consiga romper aí sim a linearidade, a fragmentação e todas as essas mazelas que a gente fala do ensino de química; eu trabalho, também na formação de professores e também na acessória às escolas a possibilidade de um professor sozinho de química fazer um trabalho diferenciado com "OI".

V- Agora ele professor sozinho?

$\mathrm{P}_{2^{-}}$Isso ele professor sozinho. Ele também cria, eu crio com ele na própria graduação, um roteiro básico que eu chamo de primeiro livro dele, em ele produz "OI" que mais ou menos foram identificados no debate com ele para digamos no primeiro ano de ensino de química, eu tenho isso aí pronto para o primeiro ano, o segundo são outros professores que trabalham isso no componente disciplinar de instrumentação para o ensino, eu trabalho com ele quatro "OI" que abarcam aquilo que se convenciona mais ou menos chamar "a química introdutória", realmente o pensamento químico e que permite depois sim você trabalhar tópicos mais específicos; essa química introdutória é também feita sobre 
[“OI”, mas só que daí compreendida só pelo ponto de vista da química,] (25) claro, com alguns apontamentos transdisciplinares, ou interdisciplinares. Então, por exemplo, uma das situações que eu considero introdutória é "OI 2", só olhado sob o ponto de vista da química, [eu posso trabalhar composição, posso trabalhar separação dos componentes do ar, posso trabalhar as substâncias, que o homem colocou ali no meio como poluentes, posso trabalhar problemas de conservação de uma substância ou o excesso de uma delas, ou problemas ambientais. Eu posso trabalhar os princípios da química, por exemplo, de separação dos componentes, trabalhando então, bases compensadas, pressão de temperatura crítica, ponto triplo, se eu trabalho o componente água no ar, quer dizer, eu tenho muitas possibilidades de trabalhar com conteúdos químicos iniciais, todos os conceitos e assim eu tenho para metais, como na segunda "OI 2", em que nos estudos dos metais ele vai compreender a relação que tem a matéria com eletricidade; ele vai entrar nas estruturas microscópicas dos átomos vai aprender as ligações químicas, vai entender a organização dos elementos na Tabela Periódica, quer dizer, eu consigo, também trabalhar dessa forma os conteúdos mais tradicionais, introdutório de química em cima de "OII", no caso então "OI 2", "OI 4" e "OI 5". Então, o que seria antigamente chamado de Funções Inorgânicas eu chamo simplesmente de comportamento Ácido-Base das substâncias em relação à água, e aí eu consigo trabalhar quantidades, tudo aquilo que eu preciso para dizer, esse aluno está iniciado na química, tem um primeiro ano do Ensino Médio bem consolidado e posso agora trabalhar como se quiser chamar de físico-química, se quiser chamar de orgânica não tem problema nenhum.] (26) Esta é uma forma mais fácil, ela tem mais sucesso, porque a outra exige toda uma reorganização da escola, mas estamos fazendo também, só que é assim, com muito menos intensidade. Essa outra é quase que uma decorrência natural de todos os alunos que a gente forma, eles acabam trabalhando dessa forma nas suas escolas e têm ficado muito satisfeitos.

V- Porque a estrutura da escola como está posta, ela favorece mais essa segunda forma é mais facilitada?

$$
\mathrm{P}_{2} \text { - Isso. }
$$

V- Eu poderia interpretar, como se fosse puxando de acordo com a situação os conceitos de química, para dar a compreensão química daquela situação, eu poderia chamála de uma intradisciplinaridade, onde eu vou puxando os conceitos da química, é isso?

P2- Isto, [ela é intradisciplinar, mas só que ela tem uma possibilidade de significação dos conceitos químicos,] (27) então, que tu saibas, pelo menos, isso, mas a interdisciplinaridade, ou a transdisciplinaridade é um produto segundário, não é o foco. No outro é o foco.

V- Nessa perspectiva, vamos continuar com o raciocínio, é possível ele dentro da disciplina, trabalhando com "OI", dando mais significado para o aluno fazer relações, é possível ele professor avançar numa perspectiva interdisciplinar? Ou seja, se apropriar de conceitos da biologia, da geografia, você acha isso possível, ou não, porque cada disciplina tem a sua especificidade?

$\mathrm{P}_{2}$ - Acho possível e acho que um bom professor, quando ele está assim, já com boa 
vivência de professor, ele vai conseguir, principalmente disciplinas que tem mais proximidade, por exemplo, ecologia com opção da química ambiental, geografia, porque ele pode tanto trabalhar, quando ele trabalha, por exemplo, minerais digamos com metais, ele pode então, ver onde essas coisas acontecem, onde se localizam, que exploração econômica existe relativa a isso. Ele tem possibilidade de trabalhar o contexto de história e também, conceitos mais próximos da área, como exemplo, ele pode digamos com um dado epistêmico avançar bastante na questão da energia cinética, produzir uma boa compreensão de temperatura, como energia cinética média, ele pode trabalhar na química as condições necessárias sob o ponto de vista da instituição para uma organização, uma auto-organização das substâncias para permitir complexificações e talvez a vida, quer dizer, é possível, mas é vamos supor assim, [é um professor que na universidade devido à preparação disciplinar,] (28) [ele não tem muitas condições, talvez com o tema, se ele coloca isso como uma preocupação de auto-formação ele vá conseguir fazer isso ter essa superação, mas muito difícil.] (29) [O melhor é você realmente criar grupos de professores que são inicialmente interdisciplinares e avançar na compreensão do transdisciplinar.] (30)

V- Nesta perspectiva do transdisciplinar, quando você está tentando trabalhar com o aluno, "OI", introduzindo um estudo mais complexo. Você acha que em algum momento os conteúdos especificos da química, da física, da biologia podem ser prejudicados, passam ser um recorte dos assuntos principais, como isso funciona?

$\mathrm{P}_{2}$ - Prejudicados não porque você tem um ganho enorme pela significação, vamos dizer, aqueles conteúdos mesmo que, às vezes, não sejam horizontalmente postos para fechar aquela estrutura feita de todos os conteúdos que foram contemplados, talvez falte alguns pontos, mas com certeza você tem incursões mais ricas que tu tens antes, ou seja, você começa a produzir novos blocos de conteúdos que antes eram completamente considerados fora de possibilidade; então, eu acho que tem um enriquecimento de conteúdo mesmo, é tanto em ganho de aprendizagem pelos significados que vão ser mais ricos, quanto em introdução de pontos, talvez vai ficar fora algum ponto que fazia parte dessa organização, na forma de uma estrutura bem fechadinha, mas que não vai fazer falta para o estudante, porque só falta para nós que fomos formados, que é essa estrutura é o que é aceita, mas para o estudante não vai fazer falta e naquilo que é avaliado hoje, tanto pelo vestibular, quanto pela prova do ENEM, ou outras formas de avaliação, ele vai, com certeza produzir respostas bem melhores do que naquela forma quase que isolada, fragmentada, em que ele só conseguia produzir boas respostas se houvesse muita semelhança com que ele teve. A forma como a gente está trabalhando, tanto, no tipo 1 que é mais complexo, como no tipo 2, ele vai conseguir produzir respostas, e assim não vai ser prejudicado, de jeito nenhum, pelo contrário, acho que vai ter um ganho, muito maior que perdas.

\section{V- E aí satisfaz tudo o que os professores querem, né?}

$\mathrm{P}_{2-}$ Claro corresponder às expectativas deles que é passar num vestibular que é seletivo, ou pelo menos, ir bem, ter a sensação, olha não fui aprovado, mas eu fui bem, tive uma boa formação.

\section{V- Compreendo.}


$\mathrm{P}_{2}$ - Posso não ter naquele momento, porque sabe, se é uma competição eu posso perder ou ganhar pode ir para a segunda divisão como foi o meu time, ou não (risos!), mas eu já voltei de novo.

V- O Palmeiras passou por isso também.

$\mathrm{P}_{2}$ - Tá certo (risos!).

V- Pensando nesta perspectiva, trabalhos com "OI", transdisciplinares, situações mais complexas, eu estou pensando assim, claro essa aula é mais dinâmica, esse aluno vai à pesquisa, esse aluno faz recortes, ele trás assuntos que naquele momento podem ser mais importantes, com o tempo ele vai aprendendo a fazer seleção desses conteúdos, mas eu queria avançar um pouco mais. Você acha possível, ou seja, dependendo desse aluno, dentro desse contexto em que ele é formado, nós fazemos alguns recortes, sobre o qual a gente achou que deveria em algum momento, pela extensão do curso, pela duração, tivemos que fazer algum recorte. Você acha possível esse aluno depois, com essa nova característica de relação de significado, ele fazendo uma pesquisa, ele vai se apropriar desses outros conteúdos que não foram trabalhados, ou seja, ele pode aprender a aprender, que seria a grande reivindicação do ensino hoje?

$\mathrm{P}_{2^{-}}$Eu acho que sim, porque ele aprende a lidar com as fontes, ele aprende a selecionar e ao mesmo tempo a gente não quer descurar que a estrutura básica do conhecimento da química no caso tenha acontecido, ou seja, ele realmente saiba que uma transformação química acontece por condições interativas entre substâncias, ou entre sítios ativos de sucessos, ou entre elementos que são de alguma forma ativados naquelas estruturas moleculares, então como a gente sabe, um esforço grande que ele faz bem quimicamente sobre o mundo, ou seja, ele pense da microestrutura que constituem o mundo real, o mundo material e, que as condições de interação podem ser modificadas, ele forma fortemente esse pensamento, sempre como preocupação central, inclusive as relações quantitativas que se dão nisso, ou as energias que estão envolvidas nisso sempre é preocupação, com certeza ele vai poder num momento de necessidade, ou no seu lazer, ou na compreensão do seu cotidiano produzir pensamentos com o apoio em pontes, eu penso que sim, o aprender a aprender é decorrência, o aprender a aprender não é processo independentes dos conceitos que constituem conteúdos próprios dos que são disciplinares. Então, o aprender a aprender, ele precisa ter um bom início, uma boa iniciação, no campo onde ele quer produzir conhecimento, o aprender coisas novas é lá tem que ser central, o processo ele é usado, e tal ele é significado, portanto isso ele vai dominar, eu penso que sim. Ele é uma forma melhor em si.

V- E como está se dando essa experiência de formação de professor, eles vão como estagiários em sala de aula , como isso está se dando?

$\mathrm{P}_{2}$ - Na formação de professores este ensino ele produzir o seu, vamos chamar de roteiro básico do curso de química, ele vai testar nas práticas, nos estágios, e nesses estágios, eu não trabalho diretamente nos estágios, mas os alunos sempre vêm me procurar, como é que eles poderiam adaptar aquilo que eles produziram tendo em vista que os conteúdos que o professor está abrindo para ele desenvolver tem algumas características 
sistêmicas, eles me procuram e a gente, então redireciona aquilo que eles produziram, a gente reorienta e eles têm conseguido dar conta, ou seja, os estudantes deles acham interessante a aula se envolvem e eles em geral, não acompanhei todos os casos, mas os que eu tenho acompanhado, eu posso dizer assim, que os professores que trabalham estágios com eles, eles ficam satisfeitos pela independência que os alunos em química já conseguiram adquirir e que, às veze, não aconteceu com outras áreas do conhecimento, como biologia, ou física, que não tem necessariamente essa preocupação que nós temos como professores de química na formação dos professores.

V- $\mathrm{P}_{2}$, muito obrigado pela entrevista, pela disponibilidade e a gentileza. 
Entrevista : $\mathrm{P}_{3}$

Data:05/08/2005

Tempo Total: 35 min.

$\mathrm{V}^{30}$ - Em decorrência do trabalho realizado na Diretoria de Ensino Região de Tupã. Isso me despertou uma curiosidade em entender a questão da interdisciplinaridade. Eu não sei se até agora os professores fazem trabalhos interdisciplinares ou não fazem, se estão tentando, se há um avanço. Por isso, eu elegi a interdisciplianridade como objeto de pesquisa. Conversando com a minha orientadora, nós chegamos a uma conclusão, me parece que na literatura tem alguns pontos de vista que divergem; e gente gostaria de saber o seguinte: Qual a concepção dos consultores dos Parâmetros Curricularesa Nacionais $\left(\mathrm{PCN}^{31}\right)$. A questão é; eu tenho lido os PCN e me parece que você participou desta construção e há uma vontade de fazer trabalhos por projetos interdisciplinares. O que eu queria entender é como esses parâmetros, ou essa literatura, $\mathrm{LDB}^{32}, \mathrm{PCN}$ recomendam isso, o que quer dizer essa interdisciplinaridade?

$\mathrm{P}_{3}{ }^{33}$ - Eu acho que você vai encontrar as repostas a essas perguntas com as pessoas que você tem contato, porque eu acho que [não há consenso geral, se quer sobre o que significa disciplina.] (1) Quanto mais sobre o que é interdisciplinaridade. As fronteiras entre as disciplinas nem sempre são claras se quer na pesquisa. O problema não é o ensino interdisciplinar é a própria pesquisa. Se você olha, se você quer acreditar que na antiguidade já se fazia ciência na antiguidade grega. O sujeito deixa de ser filósofo e começa a ser físico quando? Está certo? Então, você já não tem aí uma demarcação muito clara. A partir da Renascença em diante você pode começar a demarcar um pouco mais claramente. Vamos pegar um período um pouco mais moderno, pegar a passagem do século XIX para o século XX, a pesquisa de Becquerel e Curie eram físicas ou químicas? Vamos disputar a posse desses pesquisadores? Você é químico, vai falar: não; é química porque está definido, o que que há? Não sei o quê, o próprio objeto de todo substância elemento, você define naquele momento, o próprio atomismo não está definido. E algum dos (...) que nós chamamos de (...) e então [não há fronteira nítida se quer entre pesquisas científicas;] (2) então no ensino por essas e outras razões, você pode ter diferentes demarcações químicas, mas já num outro aspecto que eu queria chamar a atenção. Quando se tenta ensinar ciência, salvo se você tiver a pretensão e mesmo [se você tiver a pretensão de formar uma cultura científica que já seria um equívoco para a média da escola, o que interessa para a escola é compreensão do mundo científico tecnológico, não estritamente do científico]. (3) Isso por lado, então quando eu estou olhando uma técnica, em manter a combustão, uma transformação de energia, a função de trabalho etc., ou uma geladeira. Nesse processo há também o envolvimento da química, por exemplo, combustível.

\section{V- Como no caso da geladeira.}

\footnotetext{
${ }^{30}$ Refere-se ao entrevistador: Valdir Pedro Berti

${ }^{31}$ Parâmetros Curriculares Nacionais.

${ }^{32}$ Lei de Diretrizes e Bases

${ }^{33}$ Refere-se ao entrevistado: $\mathrm{P}_{3}$
} 
$\mathrm{P}_{3}-\mathrm{E}$ se eu olho a produção de energia com a matemática, como a matemática é importante no Ensino Médio, eu tenho ciclos da biosfera que são tão biológicos, quanto químicos, quanto físicos; então a compreensão da biosfera e de seus ciclos, ou seja, para apropriação energética, seja para outra finalidade, ela implica um debruçar de diferentes ciências, tá certo, só isso. Para compreender a biosfera, eu posso estar dizendo pirâmide prótica da biologia, eu posso estar dizendo a química orgânica, então,[a temática que precisa estar na escola que é parte de uma cultura cientifica tecnológica essencial para educação básica, ela não tem uma demarcação clara,] (4) se [você insistir em uma demarcação clara, você mutila o seu objeto.] (5) É como dizer, olha como eu sou psicólogo eu não quero saber do seu corpo, só lido com a cabeça, isso é uma loucura! Não existe cabeça descolada do corpo, muitas das coisas que a gente sente e pensa, a psique não está limitada ao cérebro, mesmo porque parte da psique é sexo, e nem todo mundo tem o sexo na cabeça, esse esquartejamento da natureza disciplinar, isso precisa ser olhado com muito cuidado, quando você pensa no objetivo da escola, as tecnologias tem que estar necessariamente associadas às ciências, e as tecnologias raramente são disciplinares, geralmente as tecnologias são interdisciplinares, mas não é só isso, nós temos uma tradição de que a ciência a ser ensinada na educação do Ensino Médio, por exemplo, são biologia, física e química, matemática, se quiser acrescentar matemática em ciência; Ora, e astronomia? e a cosmologia? Não precisa ensinar cosmologia? Não faz parte da visão de mundo você de ter a idéia de como nós estamos no Cosmos, o processo evolutivo etc. A física toda com certeza precisa incorporar isso, e os PCN, você sabe sugere fortemente a incorporação dos temas de cosmologia envolve alguns aspectos astrofísicos e aspectos também filosóficos é impossível filosofar hoje sem pensar num modelo padrão de evolução do Universo, se teve começo para onde vai, são questões físicas e também filosóficas. Então, [salvo se a gente pretender um aprendizagem estritamente propedêutico, pré-vestibulinho e perverso e esquartejado e maluco!] (6) Se você não fizer essa loucura tem que ser necessariamente interdisciplinar para qualquer acepção da interdisciplinaridade. Os projetos interdisciplinares é uma versão da interdisciplinaridade, eu vou fazer um projeto escolar para digamos, alunos da escola média compreendam a estatística, a relação entre estatística de saúde e condições de poder aquisitivo da família ou a existência ou não de saneamento básico. Uma correlação desse tipo ao levantar morbidade ou causa mortis eu vou estar com uma temática mais biológica, por assim dizer, doenças pulmonares, doenças infecto-contagiosas, doenças degenerativas; eu tenho uma lista de doenças para qual, os conhecimentos mais relevantes são, quando eu vou olhar outros aspectos, eu vou olhar, por exemplo, para os aspectos sociais, ou aspectos até físico-químicos; então, um projeto, às vezes, é bastante rico porque ele transcende até a sala de aula, não é só a disciplina. Ele vai para o mundo e vendo o mundo, etc.

\section{V- Uma metodologia interessante, é que ele vai ao contexto.}

$\mathrm{P}_{3}$ - Exato [eu faço em meu curso e recomendo aos professores que eu formo "Pesquisas Ambientais" ("PA") dentro das disciplinas não precisa ter projetos envolvendo as demais disciplinas.] (7) [Você pode ter um projeto de física ou de química ligado com a questão ambiental,] (8) por exemplo, não há nada melhor ou forma mais adequada de medir o nível de contaminação de um riacho do que medir a condutividade, porque ela é proporcional, é rápida, você põe dois fiozinhos, você vai com o voltímetro, a condutividade é proporcional à quantidade de eletrólise em condução, então é um método físico ou físicoquímico, se quisesse medir o nível de contaminação do riacho que tem haver com a 
questão social, etc. Então, [você pode dentro de uma disciplina fazer aberturas que são interdisciplinares com ou sem a cara de projetos.] (9)

V- Por exemplo, quando eu parto de uma idéia dessas, de analisar, vamos pegar esse exemplo, condutividade elétrica existente em um riacho se está poluído ou não, mas eu parto de uma disciplina, por exemplo, da física, poderia ser da química, nesse momento eu tenho professor que trabalha sozinho e aí ele vai chegar em ponto de precisar de um aporte das outras disciplinas, ou ele faz a interdisciplinaridade ou a gente poderia pensar, que ele convidaria os outros professores para fazer a interdisciplinaridade?

$\mathrm{P}_{3}$ - Ambas as soluções são possíveis, a gente tem que lidar com a realidade, o real é muito mais complicado do que nossa teoria, você imagina que em qualquer escola, você é capaz de reunir professores, para isso, não é verdade? Às vezes tem um professor que tem absoluta má vontade com qualquer uma dessas coisas. Essa má vontade é por que ele não gosta de ser professor, é um infeliz da vida está na função errada, e esse cara se você pretender que ele integre um grupo fora do horário, para pensar, já dançou o projeto. Então, é preciso tentar fórmulas, às vezes, por ser a partir de uma disciplina e você sai para outras, e aí você pode aos poucos seduzindo outras disciplinas, você começa um projeto na área de ciências e aí já envolve artes, por que a "molecada" começar a produzir painéis, teatro, então, eu acho que interdisciplinaridade é uma necessidade, mas pode ser suprida de diferentes maneiras, e projetos envolvendo muitas disciplinas para a escola que eu conheço é mais ponto de chegada do que ponto partida, na maior parte das escolas, recomendo, mas não é forçoso. Às vezes, basta juntar duas disciplinas, às vezes, você consegue em três, às vezes, você parte de uma só e já é um projeto interdisciplinar, [porque o interdisciplinar é o contexto pelo qual você vai fazer a investigação.] (10) E eu acho que uma dessas habilidades ou das competências que o aluno tem que adquirir é selecionar vaiáveis, ele pode estar num contexto muito rico, mas ele seleciona as variáveis e vai naquelas variáveis e interpreta. No exemplo, de medir a condutividade do rio para verificar o nível de poluição é claro ver, porque eu estou selecionado uma variável e vou interpretar, o que significa que se tiver uma condutividade alta da poluição, não necessariamente eu posso ter uma salmoura não contaminada com alta condutividade, não é certo?, mas agora eu sei que o riacho não é de salmoura, o riacho tem é muita sujeira e parte dessas sujeiras são eletrólitos. Então, [essa capacidade de abstrair dados é um aprendizado importante, porque o mundo não é colocado assim, na bancada do seu laboratório, já dividido em disciplinas eu acho que uma das competências mais importantes no aprendizado de ciências é você identificar as variáveis relevantes.] (11)

V- E uma outra coisa, nessa questão, por exemplo, que se fala muito na literatura, quando os professores estão conversando sobre um tema e as disciplinas estão trabalhando independentemente, você teria mais uma multidisciplinaridade, a interdisciplinaridade pressupõe que você está junto discutindo, existe mesmo essas etapas de interdisciplinaridade, ou isso acontece durante o trabalho?

$\mathrm{P}_{3}$ - Eu acho até que existem essas etapas, mais eu não as levo a sério. Eu acho que isso é mais uma contabilidade de palavras do que uma coisa séria. Até onde é inter? Até onde é trans? No geral isso é conversa jogada fora, a meu ver, mas pode ser que eu esteja 
um pouco caricaturando as coisas. O que interessa é lidar com a realidade vivencial do aluno, do sistema produtivo, da sociedade, e ser capaz de ter sobre isso um pensamento prático, propositivo, crítico e analítico. Nesse esforço você vai ter elementos que são claramente interdisciplinares, porque é impossível não ter, mas às vezes você tem que fazer um exercício de separar uma variável e ela pode ser mais claramente disciplinar; então, você pode ter, vamos sair um pouquinho da nossa ciência da natureza e vamos pensar nas ciências humanas. Uma condição social, micro-social pode estar agravada, por exemplo, pelas questões de natureza psicológica.

V- No século XXI pela ansiedade do consumismo?

$\mathrm{P}_{3}$ - Pois é, aí talvez a coisa seja ainda mais complicada. Então, você tem problemas que são de natureza filosófica, sociológica, você tem que tomar o Marx como filósofo, tá certo? Na questão da política, social ou filósofo? Porque pode ser de muitas, hoje no almoço tínhamos a discussão se o Marx filósofo não era mais sobrevivente que os outros Marxs de certa maneira. Eu não estou desqualificando essa discussão, mas no que toca a interdisciplinaridade, para um esforço educativo, quando você discute os PCN é disso que se trata, quanto menos classificação e contabilidade menor, melhor.

V- Por exemplo, educação básica, o que está acontecendo é uma falta de compreensão dos professores em fazer esse tipo de trabalho.

$\mathrm{P}_{3}$ - Não são só os professores.

V- O que está acontecendo na escola pública?

$\mathrm{P}_{3}$ - Não está acontecendo. Não está acontecendo uma atitude mais ampla do que pensar o sentido da escola. Quais as funções que a escola precisa ter nesse mundo de hoje? Nós temos uma herança posta da sociedade industrial que já acabou. A escola acadêmica não vai qualificar as pessoas. A escola foi feita para selecionar as pessoas. E a escola não foi feita para produzir valores diferentes, mas para nivelar e pastuerizar. Ela separava, nivelava e domesticava, porque a escola reproduzia a pirâmide da sociedade industrial, você tinha três ou quatro pensantes, os intelectuais orgânicos da burguesia, para lembrar do Gramsci; você tinha os detalhadores que eram os engenheiros de pranchetas, o supervisor, o encarregado e tinha uma ampla base, uma massa que podia ser analfabeta, que mal soubesse ler para pegar o ônibus direito. E que não fazia uso de nenhuma dotação cultural especial no seu trabalho, essa estrutura é reproduzida na escola. Meus colegas de turma no primário deixavam a escola no segundo ano, por muitas deficiências para passar do quarto ano para o quinto, que seria hoje o quinto ano tinha o exame de admissão, que era o vestibular, era o vestibular para saber quem ia para o ginásio, tá certo? Que era a segunda metade hoje da quinta a oitava. Essa escola é ainda a nossa escola até hoje.

\section{V- Ela permanece?}

$\mathrm{P}_{3^{-}}$Permanece, porque você não faz a idéia de aprender ciências com ninguém, entendeu? O "carinha" que decora a mitocôndria no livro, ele não sabe, não tem a menor idéia e mais isso é dito sem nenhuma noção, o sujeito memoriza aquela organela. Bom, se 
você vai fundo nessa mitocôndria ela é incrível, do ponto vista físico, ou físico-químico, ela é uma usina de energia, ela é a empacotadora do deslocamento do trifosfato de adenosina; do ponto de vista genético, ela é incrível! A mitocôndria não tem o mesmo DNA nuclear, a mitocôndria tem o DNA próprio e que não muda muito, porque ele não se combina com o DNA de pai e mãe, então ele é uma linha matrilinear e de baixa modificação; é fácil, você pode traçar origens, assim, de séculos de ascendência via DNA; quer dizer é uma coisa matrilinear, você podia ir até Eva sem passar pelo Adão. Então, essas coisas belíssimas da genética, do pensar a evolução, origens, isso dito com absoluta deficiência, nem do ponto de vista da formação cultural e da visão mundo, nada, porque o professor também não tem visão de mundo, o coitado também memorizou aqueles "trecos", o livro reproduz esse "bobajau" que é memorizar, enfim certas coisas ou aprender algoritmos, Deus sabe para quê. Veja só como [se ensina logaritmos na escola, operação inversa da potenciação, e daí? E o resto? Agora, que o logaritmo seja a linguagem da química para o pH? Que é (-log) da concentração de íons de hidrogênio; ou que a linguagem da física nos decibéis, ou na geologia] (12) na Escala Richter. O cidadão não sabe isso, ele ensina uma gramática numa língua que ela não sabe falar. É como se os professores de língua inglesa e francês que não falam, só ensinam gramática; Então, a escola virou uma caricatura da cultura que deveria promover, que dizer, nós entramos na interdisciplinaridade, você percebe nós estávamos falando de logaritmo, estamos falando de química, de acústica, por que? Porque você tem uma escola que encontra atrasada, desaparelhada e ineficaz. Quem é que está se revoltando contra a escola? Os alunos, eles têm uma atitude ou de revolta ou de apatia. O aprendizado cai vertiginosamente, o professor é desrespeitado e o aluno percebe que ele não fala à língua que ele está ensinado.

V- E não há uma política pública de incentivo a esse profissional; então trabalho dele é péssimo.

$\mathrm{P}_{3}$ - É claro, mesmo porque o Estado paga muito mal.

V- Teria algum local em que este tipo trabalho está acontecendo, do ponto de vista da interdisciplinaridade?

$\mathrm{P}_{3}$-Tem, tem um pouco neste país, sim. Por insistência deles no passado acabei auxiliando a compor um modelo diferente de educação na escola "P.D." e aproveitei a oportunidade para formar alguns dos meus pós-graduandos para eles crescerem etc.

V- Essa escola é de nível superior?

$\mathrm{P}_{3}$ - Não é de Ensino Médio, deixa eu ver se eu acho um texto que tenha exatamente esse exemplo que dei, aqui você tem uma definição formal. Você tem os decibéis, você tem todos aqueles detalhes do que é decibel disso e daquilo e porque você precisa estudar logaritmo, classificando as soluções, aqui você tem $\mathrm{pH}$, escala Ricther, podendo estar presente, isso tudo é matemática. Eu coordenei essa série e escrevi meia dúzia de livros. Então, há esforços neste sentido, belíssimos esforços.

V- E essas escolas, por exemplo, desculpe voltar nessa questão, mas acho que é muito forte o argumento, que sempre para usar contra, e essas escolas e o vestibular? 
$\mathrm{P}_{3}$ - Pois é essa é uma preocupação grande dos pais, isso não vai virar no vestibular, e tal. Esses jovens dessas escolas, cada um deles tem três computadores, tem um na escola, que ela fornece, tem um em casa, tem um laptop, está plugado em tudo, sabe, e fazendo uma escola com a preocupação em formação cultural e tal, eles ficam de tal forma ligados, qualquer que seja o esforço eles passam em qualquer vestibular. Mais ou menos eu costumo fazer a seguinte metáfora. Se você tem filhos e os quer com saúde, você quer que eles façam exercícios físicos, que joguem bola, que vá fazer diferentes esportes coletivos ou individuais etc, um vai fazer judô, o outro vai para o vôlei, não necessariamente vão ser atletas olímpicos, tá certo, mas se eles tiverem boa dotação física, boa alimentação e os movimentos, eles podem se quiser se tornar atletas, vai depender dessa vocação, dessa busca, etc. Pode haver o vestibular competitivo para determinadas carreiras, não são todas, por exemplo, para entrar aqui na Física, se você tiver QI de médio para cima e tiver terminado qualquer escola média, mesmo pública, de alguma qualidade, entra; porque processo de corte é muito baixo.

\section{V- Na química também.}

$\mathrm{P}_{3}$ - Para ser cientista a competição no Brasil é baixíssima, a competição de entrada, não estou dizendo que ele se torne, pode ser que ele se torne um bom cientista, também, mas se você quer uma carreira muito competitiva, é um espaço olímpico. O esporte olímpico você não aprende na escola; o esporte olímpico você precisa ter treinamento intensivo, alimentação adequada, supervisão técnica. A coisa mais maluca que teria é agora toda a educação física brasileira vai ser esporte olímpico e como passar o Ensino Médio todo a serviço dos poucos vestibulares realmente competitivos, isso é um contra-senso.

V- É verdade, $\mathrm{P}_{3}$, obrigado pela disponibilidade. 
Entrevista: $\mathrm{P}_{4}$

Data: 22/06/2005

Tempo Total: 46 min.

$\mathrm{V}^{34}$ - Uma forma interessante que a gente poderia começar, talvez seria falando sobre seu artigo, o qual se refere ao conceito de "Complexidade Geométrica do Conhecimento" ("CGC") e que pra mim, eu não sei se entendi bem, seria a totalidade, gostaria que você falasse um pouco disso e depois a gente se deslocasse um pouquinho para esse recorte da interdisciplinaridade, pode ser?

$\mathrm{P}_{4}{ }^{35}$ - Pode é claro. A idéia é a seguinte, quando a gente criou esse conceito de "CGC" a idéia era tentar fazer uma geometrização do espaço do conhecimento, então você supõe que o espaço do conhecimento é criado por idéias, conjunto de idéias que você pode dizer que são conceitos. E que eles têm ligações entre si, as coisas têm ligações entre si, das mais diversas naturezas, eu não estou dizendo da natureza das relações entre elas, estou representando o espaço do conhecimento como um conjunto complexo, o que é um conjunto complexo? É um conjunto composto de uma infinidade de indivíduos altamente conectados entre si.

\section{V - Como uma teia?}

$\mathrm{P}_{4}$ - É então, o Nilson Machado fez aquele exemplo da teia, mas eu acho que a complexidade geométrica é um pouco maior, porque as dimensões entre cada ponto elas podem ser, elas são de diversas naturezas e de quantidades, tá certo? Então, a pergunta é toda vez que a gente vai construir um currículo, o que a gente faz? A gente pega um determinado conjunto de conhecimento e na verdade a gente faz um recorte sobre ele baseado em alguns critérios que nem sempre estão explícitos e que a gente chama de critérios ontológicos, epistemológicos e axiológicos, [esses critérios ontológicos é sobre a compreensão que você tem da natureza das coisas] (1) sobre a qual você vai falar; [o epistemológico é que tipo de conhecimento é esse?] (2) Quais são os limites desse conhecimento? Qual é a natureza desse conhecimento, do qual você está querendo falar [O axiológico são os valores que estão ligados na escolha desse; os fins,] (3) a idéia é essa, valores sociologia está ligada a uma ciência, é um nome antigo que hoje em dia está mais ligado a teoria de valores; então se usava a axiologia para se falar da teoria de valores, mas de uma maneira mais relacionada não só a valores éticos, mas também aos fins das ações. Então, por exemplo, [qual é o fim da educação, o que você quer da educação, na hora que você está fazendo esse recorte].(4) Você tem toda essa montanha de coisas que nem sempre estão explícitos, [a idéia da gente explicitar, os critérios dessas três categorias era de que você poderia fazer, de que o professor ao fazer o recorte no conhecimento para a construção, para seleção de conteúdos escolares ele tivesse claro ele tivesse um recorte responsável,] (5) o recorte responsável está ligado a isso, a essa compreensão dos critérios que você está usando para fazer aquela escolha.

\footnotetext{
${ }^{34}$ Refere-se ao entrevistador: Valdir Pedro Berti

${ }^{35}$ Refere-se ao entrevistado: $\mathrm{P}_{4}$
} 
V - O professor, por exemplo, da educação básica do Ensino Médio, ele tem isso em mente, está claro para ele?

$\mathrm{P}_{4}$ - Não, acho que não, na minha opinião algumas coisas estão claras, mas são poucas, quer dizer, [os currículos normalmente estão sendo construídos, basicamente por inércia, quer dizer, a escolha do enfoque não só dos conteúdos, mas do enfoque que você vai dar a ele, ela está muito ligada a uma reprodução da prática,] (6) para mim, em média a maioria está acontecendo isso, tanto a reprodução de conteúdo, quer dizer a seleção dos conteúdos, é um professor de física ou de química, por exemplo, eu uso o de física, porque é o exemplo que me vem mais fácil, várias pessoas escolhem o Ramalho, que é um livro que eu não gosto, eu acho que, quer dizer para os fins, no qual o Ensino Médio está destinado ele se tornou um instrumento importante, porque ele ajuda o sujeito a passar no vestibular. Agora do ponto de vista da formação do cidadão e da formação humana adquirida, ele tem uma contribuição muito pequena, se você hoje em dia e eu vejo no curso de licenciatura, por exemplo, a formação de professores peço para um sujeito me construir um currículo, um conjunto de conteúdos para o Ensino Médio, a grande maioria vem com uma cópia do Ramalho.

\section{V- Como foi o Feltre na Química?}

$\mathrm{P}_{4}$ - É como foi o Feltre na Química, durante muitos anos, o modelo de seleção de conteúdos era aquele, que tem até o plano de aula, essa é uma outra evidência que para mim está bastante claro também que [o livro didático é usado como um oráculo, quer dizer há uma transposição direta do livro didático para o curso, quer dizer, o curso é o livro,] (7) eu não precisaria assistir o curso do professor se eu tivesse o livro. Daí essas edições novas começarem a colocar o que o professor não estava fazendo box de interdisciplinaridade, box de cidadania, box de profissão, quer dizer está fornecendo subsídios ao que o professor não estava dando conta de fazer, muitos desses livros didáticos de hoje em dia, fazem isso de maneira inadequada, a brincadeira que eu faço, é o rato $(\mathrm{R})$ perseguido a velocidade $(\mathrm{V})$ pela raposa (RA); não mudou nada, quer dizer, isso é Biofísica? Não é. Então, não é interdisciplinaridade isso do ponto de vista das formas de pensar, dos conteúdos se entrelaçarem, eu já estou começando a falar um pouco da minha compreensão de interdisciplinaridade, aí eu vou voltar para o " $\underline{C G C " ~ p a r a ~ c h e g a r ~ l a ́ . ~ E n t a ̃ o, ~ a ~ i d e ́ i a ~ q u e ~ o s ~}$ recortes que você está fazendo, nessa "CGC" eles podem ter natureza de complexidades distintas, quer dizer o recorte disciplinar, por exemplo, ele pode ter do ponto de vista de que eu considero conhecimento como uma progressão contínua no tempo, quer dizer, a construção do conhecimento é uma progressão histórica contínua no tempo; então no caso da física, que é o exemplo que eu tenho mais claro, você pega a maioria dos currículos de Ramalho, o Halliday, que é dado no ensino superior, você tem a mecânica, cinemática, dinâmica, hidrostática, termodinâmica, eletricidade e magnetismo; você pega isso, de certa forma, você está fazendo uma trilha que está relacionada com a saída do macroscópico para o microscópico, mas ao mesmo tempo está ligada a uma seqüência de conceitos, ou seja, é uma cadeia lógica. Então, do ponto de vista da física eu preciso construir esse mapa conceitual, eu sei as hierarquias axiomáticas, que são para entender a aceleração preciso saber o que é velocidade, para entender velocidade preciso saber o que é posição; então eu não posso aprender aceleração. 
V - Tem que haver o encadeamento lógico?

$\mathrm{P}_{4}$ - Eu não posso aprender, por exemplo, eu não posso aprender nesse raciocínio nessa forma de pensar, eu não posso aprender calorimetria ou é teoria cinética de gases antes de falar de pressão, pressão genérica, termodinâmica clássica, sem entrar no modelo cinético molecular.

V - Não é aquela idéia dos pré-requisitos?

$\mathrm{P}_{4}$ - É então, nesse sentido sim, a idéia é de que eu tenho um encadeamento lógico entre os conceitos, que do ponto de vista do aprendizado é até necessário, tem gente que faz essas rupturas e inverter as coisas, quer dizer, passa a dar, por exemplo, ótica no primeiro ano, ou termodinâmica no primeiro ano do Ensino Médio e no segundo vai dar mecânica, então você parte, na verdade de regiões onde você não explica os conceitos primários, você supõe que o cara entenda o que você está falando e vai embora. Do ponto de vista operacional funciona muitas vezes quer dizer, não necessariamente do ponto de vista cognitivo, [quer dizer o sujeito compreender aquilo como dentro de uma teia de conceitos.Então, isso eu estou falando de um recorte disciplinar,] (8) quando eu faço um recorte disciplinar estou falando da questão da intradisciplinaridade.

\section{V - Mais dentro da disciplina.}

$\mathrm{P}_{4^{-}}$No sentido de que você pode, você vê que as escolhas dentro das disciplinas podem alterar, podem mudar, as relações entre as partes das disciplinas dependem de como você entende o conhecimento, do como você entende a natureza das coisas e depende dos valores e dos fins que você está interessado com aquela sequiência de conteúdos que você está propondo, não é? Esse seria o mais simples, mais simples e ao mesmo tempo complexo, o recorte disciplinar e ao mesmo tempo você tem problemas intradisciplinar. A disciplina quando você pensa em física, às vezes, ela é dada, ou química provavelmente deve acontecer coisas semelhantes, se você pergunta a um aluno do primeiro ano de física, do terceiro de física, se a mecânica que ele viu na física um é a mesma da disciplina de mecânica clássica que ele viu no terceiro, ele vai dizer que são coisas diferentes; você tem essa segmentação do conteúdo que diz respeito a uma convenção epistemológica do conteúdo, que é uma opção coletiva, por exemplo, das instituições, você pega uma instituição e não o professor isolado, o currículo da física, ele está segmentado intradisciplinarmente [de maneira que perdeu conexão lógica entre as coisas, lógica, epistemológica e axiológica, os critérios não estão claros, foram construídos por diferentes pessoas no tempo e não foram feitas conexão entre eles]. (9) Então do ponto de vista intradisciplinar [há uma disjunção dos conjuntos de conhecimento, é como se eu pegasse, essa "CGC" e fizesse um recorte disciplinar e criasse vários e esse recorte é composto de coisas isoladas entre si que não tem conexão.] (10)

\section{V - A idéia é que o aluno fizesse, não é isso?}

$\mathrm{P}_{4}$ - Não, não eu acho que o aluno não faz isso sozinho, precisa do professor para fazer, e, às vezes, os professores não fazem, eu acho que o professor não faz, a mesma coisa é fazer a conexão com o cotidiano, quer dizer, não adianta querer que o aluno perceba 
a conexão da ciência com o cotidiano se os professores não fizeram as suas e dão como exemplo, essa é uma forma de se abordar a interdisciplinaridade, por exemplo, como eu vou fazer um recorte agora interdisciplinar, [busca construir conexões com conteúdos que dizem respeito a várias disciplinas,] (11) ou as duas delas, conteúdos na minha "CGC", faço um recorte na escolha de um conjunto de conteúdos que tem uma seqüência, que pode ter diversas seqüências, mas eu estou supondo uma, mas que envolve por exemplo, no caso em que, às vezes, pra mim é mais fácil pensar na biologia e na física, então você pensa em dinâmica de populações, quando você está falando em dinâmica de populações a modelagem que a física faz dos problemas biológicos da dinâmica, implica que o sujeito tem que compreender a biologia, porque senão, porque perde nuances que são da biologia que não dizem respeito a física, se ele quer modelar aquilo ele tem que aprender biologia, senão ele vai falar do rato (R) da raposa (RA) etc e tal, quer dizer, ele tem que se interar daquele ponto dentro da biologia, que sentido tem aquele conteúdo dentro da biologia, se não ele simplesmente pega um problema, isola aquele problema, ao invés de chamar raposa e coelhos, ele chama de (R) de (C) e cria uma dinâmica entre eles e tal e você cria um modelinho que pode ser aplicado a biologia ou não. A pergunta é se eu quero ensinar ao sujeito ao usar física a usar instrumento da física dentro da biologia a gente precisa aprender biologia também, esse ponto de vista para mim está mais claro isso. E isso não significa botar um professor de biologia e um de física dentro da sala de aula, isso não significa isso, porque as conexões, é isso o que eu estou falando da mesma forma do cotidiano, o professor tem intimidade [com as conexões implica ele dominar elas, além do conteúdo da física], (12) implica fazer essas ligações, eu preciso dominar o cotidiano, preciso os fenômenos do cotidiano com os instrumentos da física e ver a relação entre essas duas coisas para poder falar com o meu estudante, a mesma coisa é a biologia para mim, senão ele vai ter o problema de física como outro qualquer, cujo mote é falar eu não chamo isso de interdisciplinaridade.

V - Mas o professor atribui, por exemplo, essa dificuldade de conversar de trocar experiências juntos e a ponto de um compreender o conceito de cada disciplina?

$\mathrm{P}_{4^{-}}$Não, a disciplina não isso são dois problemas distintos, eu acho que a incompetência, digo por formação, você pega na universidade na física, é raro cursos, cujos exemplos são interdisciplinares, é raro isso eu estou falando do ponto de vista de formação do físico bacharel e você pega o licenciado para mim cada vez está mais claro aqui que eu estou começando dar aula aqui neste ano, mas obviamente, que na Unesp acontecia uma coisa muito semelhante, quer dizer, você pega os professores eles são disciplinares e intradisciplinares disjuntos, eles ensinam aquele microcosmos da sua disciplina e não sabem a relação com outras disciplinas da física, quer dizer, daí alguns de meus trabalhos estarem ligados a isso de você propor problemas, por exemplo, o Demônio de Maxell, não sei se você conhece o Demônio de Maxell.

\section{V- Não, não conheço.}

$\mathrm{P}_{4}$ - É um problema que você pode estudar a química e depois vai ter interesse, você bota lá dois compartimentos com gás e tem um demônio que não gasta energia, não realiza trabalho, para selecionar as moléculas rápidas para um lado e as lentas pro outro. Então, o que ele vai fazer, ele vai aumentando a temperatura de um lado e diminuindo do outro na 
medida que ele seleciona as rápidas de um lado e as lentas do outro, sem realizar trabalho você vai contra a Segunda Lei da Termodinâmica, você não está gastando energia para criar ordem, este é o ponto, então quando você vai falar disto, esse problema, quando você olha a história da ciência na física, na química e na biologia, você vê que ele tem diversas implicações nestas disciplinas, como teoria de formação, esse demônio, esse problema surgiu na física. Eu estou falando isso porque eu trabalhei com isso na universidade, o meu mestrado foi ver como o conceito de entropia surgia na física e como que ele saia da física para a biologia e para a teoria de informação, como que as outras disciplinas vão se apropriando dos conceitos, na sua teia conceitual disciplinar para explicar fenômenos que estavam restritos a área na qual eles originariamente vieram. Mas, só que você começa a contaminar a disciplina com conceitos de outra área, você começa a criar essa interface, porque as pessoas começam a achar que podem falar, uma das outras, assim como eu acho que área de ensino de ciências é uma área interdisciplinar por conta de que o sujeito tem que saber ciências e educação, se não souber ciência e educação o que ele, vai fazer? Não faz! O exemplo mais claro para mim é esse, você tem que saber as coisas, agora não significa que você tenha que saber tudo, porque para você ser um especialista em uma determinada linguagem, vamos supor está na escolha dos problemas que você que enfrentar na sua vida como pesquisador nessa hora, quer dizer eu posso querer saber muito bem mecânica quântica, o que eu vou fazer? Eu vou ter uma profundidade na mecânica quântica, eu vou ser um expert naquela linguagem, o número de indivíduos que vai ter conexão comigo vai diminuir muito, porque são poucos experts, ao mesmo tempo se eu vou pra uma área interdisciplinar o campo que eu tenho para cobrir é muito maior, eu não posso também querer fazer um vôo sobre todo o campo, porque como diria o Japiassu ele fala o especialista é o cara que sabe tudo sobre o nada, e o generalista é o cara que sabe nada sobre tudo, a pergunta está nesse no jogo de palavras complementar, quão profundo e extenso eu posso ser no campo interdisciplinar, agora isso é fundamental você encontrar gente que tenha o mesmo tipo de interesse para construir o grupo interdisciplinar.

\section{V- Aí teria alguma coisa relacionada com afinidade, por exemplo?}

$\mathrm{P}_{4}$ É claro diz respeito ao critério de valor, os quais os fins daqueles conhecimentos que eu estou propondo para ser ensinado está ligado a isso. Não sei se você entendeu. Eu como indivíduo estou tentando dominar dois campos, agora eu pra me formar em física e em educação para fazer ensino de química eu preciso fazer [a conexão entre essas coisas que demanda tempo, muita leitura e muito estudo, eu estou tendo que ler duas áreas, eu estou tendo que fazer conexões que não estavam montadas, eu estou tendo, todos nós que vamos fazer nesta área temos que fazer essas conexões pessoalmente, não adianta o outro contar para gente que fez, eu tenho que construir as minhas,] (13) eu posso até ver a dos outros, como exemplo, mas eu tenho que construir as minhas, vou fazer as minhas conexões, [eu tenho que encontrar jeito, eu quero encontrar gente que faça isso com a química e com a biologia, porque eu posso além, fazer ainda assumir a complexidade, estava falando de educação em física, agora estou falando de educação em física, química e biologia, como a gente pode trabalhar junto, o campo de conhecimento, o recorte que você faz na "CGC" ele aumenta exponencialmente o conjunto de conteúdos que estão ligados, você criar, você perceber ligações entre áreas que antes estavam disjuntas é duro de você construir, não é fácil, agora você precisa entender das duas áreas para conseguir fazer essas ligações, você não consegue entender tudo, mas alguma coisa;] (14), são esses exemplos é 
que vão ajudando as pessoas a se comunicarem nos grupos interdisciplinares, você fala da escola, por exemplo, seria ótimo se todos fossem pesquisadores em ensino de ciências, os professores de química, física, biologia e matemática teriam algo em comum a conversar que na interface da sua disciplina com a educação, eu tenho muito a ganhar com o ensino de matemática, com os resultados na área do ensino de matemática, eu não sei matemática bem, sei razoavelmente educação, mas sei bem física, então várias das ligações entre a física e a educação são semelhantes àquelas feitas entre a educação e a matemática, que são semelhantes àquelas feitas entre a educação e a química, entre a educação e a biologia, nesta hora eu posso começar a me apropriar de um conteúdo que é de ordem de complexidade um pouco maior do que eu tinha antes; não sei se você está entendendo o que estou falando.

V- Me parece que as coisas devem caminhar para dois momentos, ou dois momentos ou apenas um, por exemplo, o professor fazendo a interdisciplinaridade até para que ele possa se apropriar disso com significado.

$\mathrm{P}_{4}$ - Para formação pessoal.

V- Ou senão, ele fazendo dessa forma e tendo um momento de compartilhamento com outros professores, o que não tira a necessidade de ele fazer primeiro essas relações pessoais, seria isso?

$\mathrm{P}_{4}$ - Eu acho que o primeiro passo do pessoal, depois se constrói os grupos.

V- O primeiro momento, certo? E o que a gente percebe na escola, ou pelo menos, em algumas escolas de Ensino Médio, é que os professores pegam um tema e vão trabalhar e não saem daquilo.

$\mathrm{P}_{4}$ - Não consegue se entender, porque não tem linguagem comum.

V- Isso e a interdisciplinaridade pressupõe isso.

$\mathrm{P}_{4}$ - Exatamente. do inter?

$\mathrm{P}_{4}$ - E qual a diferença, professor do intradisciplinar dentro da disciplina? Do multi e

$\mathrm{P}_{4}$ [O multi é que você está falando, o que está sendo feito, você junta um monte de "nego" de cada disciplina e eles ficam contando um para o outro, aquilo da sua disciplina, aquele cara não consegue visualizar a ligação das coisas dele com a do outro,] (15) ele só ouve o que o outro fala, então fica aquela coisa, né? É óbvio que pode até surgir numa reflexão mais profunda, começando, por exemplo, estou lá reunido com o pessoal da biologia começo a ouvir o que eles estão falando, ai começo a tentar fazer ligações entre o que eu faço, entre o meu conhecimento que eu domino e aquele conhecimento, aí eu falo, bom vou me basear só no que ele está falando, não, vai ter que estudar, vai ter que ler, fazer relações, vai ter que estudar; então, se você já tem um princípio, uma formação, ou um desejo de você estudar o conteúdo, você já chega no ponto da discussão com uma "picada" 
mais ou menos, mais desbastada, talvez o nego chega cru, nunca ouviu falar de biologia, nunca se interessou por biologia na vida, ai vai ter que sentar junto com o biólogo e estrear uma atividade, ai você fala "pô" como é que a gente vai fazer?, Então tá vamos botar a raposa e o coelhinho, a raposa $(\mathrm{R})$ e coelhinho $(\mathrm{C})$, andando numa linha reta, a velocidade constante e (Ft) é igual a quanto? Aí o que é isso, isso é biofísica?

V - E a introdução de uma aula interdisciplinar pensando nisso?

$\mathrm{P}_{4}$ - Não dá, é a mesma coisa, quer dizer aula interdisciplinar, por isso que eu estou dizendo a você a experiência que tenho tido, [eu tenho tentado com meus alunos de produzir material de subsídio à formação de professores para a introdução da interdisciplinaridade na sala de aula,] (16) ai estou dizendo no meu caso particular, o trabalho que tem me dado estudar outras coisas é enorme para fazer ligações, para tentar fazer com que os outros vejam as ligações dar exemplo de ligações, para mostrar que não está isolado, que o mundo não é disciplinar, que o problema do mundo quando você vai olhar, por exemplo, vamos introduzir o cotidiano na química, o que é isso? É uma "puta" interdisciplinaridade, porque se você olha a química como uma disciplina, e um conjunto de regras e fenômenos que a química advoga, estão ligados ao isolamento do mundo cotidiano no sentido de que para se manifestar os fenômenos você tem que isolar eles no laboratório para mostrar que aquilo ocorre, vamos medir o oxigênio que saiu da reação que deu, agora para voltar ao cotidiano é uma complexificação do conhecimento, aí meu amigo, tem problema de todas as naturezas.

\section{$\mathrm{V}$ - E é talvez por isso que se corre tanto.}

$\mathrm{P}_{4}^{-}$Então, e aí no cotidiano se eu penduro o barbante numa pedra e balanço o cara fala o que é isso? Você fala é uma pedra balançando num fio, se você está com os teóricos da física, eles falam que é um pêndulo, então é duro fazer essa construção conceitual porque o que vai mediar você é essa ponte, aí eu estou tentado usar o Vygotsky para isso, quer dizer o que é que vai mediar, como que eu vejo um mundo interdisciplinar, é o domínio da linguagem que eu tenho para expressar aquele mundo interdisciplinar, se eu não conheço as linguagens múltiplas daquilo e crio linguagens comuns para expressar aquilo de maneira interdisciplinar eu falo como um físico ou falo como um que é a multidisciplinaridade. Tema água, física fala da água, química fala da água, bom tudo bem.

\section{V - Entendi, eu tenho que me apropriar mesmo da linguagem de cada disciplina.}

$\mathrm{P}_{4}$ - Não é se apropriar e criar nível de complexidade superior que é você ver o fenômeno nas duas formas, então hoje em dia quando eu falo de um fenômeno na área de ensino da física eu não estou mais falando só de física ou de educação ou no ensino da química, você não pode olhar mais um fenômeno é obvio que você pode olhar um fenômeno numa reação química, mas o fenômeno dessa área é a reação química com os alunos, com o professor, tudo ao mesmo tempo. Se eu quiser fazer recortes disciplinares, eu faço, eu vou fazer só o fenômeno químico, só a pedagogia, ou do ponto de vista da pedagogia só o fenômeno educacional, não dá, não é assim.

\section{$\mathrm{V}-\mathrm{Na}$ verdade eu estou fragmentando.}


$\mathrm{P}_{4}$ - Exatamente eu volto a ser disciplinar nessa hora.

V - E é isso o que está ocorrendo, né?

$\mathrm{P}_{4}$ - Com certeza.

V - E a questão da transdisciplinaridade que as pessoas falam tanto.

$\mathrm{P}_{4}$ - Transdisciplinaridade eu acho que é um conceito equivocado, equivocado não, ele tem sido usado de tantas maneiras, já tem gente exotérica usando isso para todo lado, então eu acho que se você for pegar é uma interdisciplinaridade de complexidade superior, é quando você pensa nas disciplinas como um todo, né? Então se você olha, eu não sei se você viu lá no "artiguinho" têm aqueles esquemas. Você pega a interdisciplinaridade é como se você pegasse a coleção de disciplinas e transformasse nelas como uma grande interdisciplinaridade

V - Entendi, uma etapa superior de interdisciplinaridade.

$\mathrm{P}_{4}$ - É [seria uma interdisciplinaridade da interdisciplinaridade, você vê as várias conexões entre elas, engloba todos os níveis hierárquicos inferiores, física com química, física com biologia, física com química e biologia juntos, pares, trincas, quádruplas, e assim por diante, quíntuplas, todos os níveis, as "CGC" são as transdisciplinaridades das transdisciplinaridade,] (17) você sempre percebe isso, você vê que, agora a pergunta está do ponto de vista do indivíduo, da formação do indivíduo, como que eu concebo a formação do cara nesse sentido, é obvio que aí volta para o problema daquele balanço complementar profundidade e extensão, como que eu consigo e daí a necessidade de você juntar com mais gente, porque se a extensão aumenta a profundidade diminui e então eu tenho um jogo complementar em me aprofundar nas áreas mas, não posso ser extenso demais, eu preciso de ajuda, preciso de gente que e não um conjunto de negos em poços profundos, que é uma multidisciplinaridade.

\section{$\mathrm{V}$ - Ela conseguiria as duas coisas.}

$\mathrm{P}_{4}$ - Então, mas eu acho para mim o problema está no fazer as coisas, quer dizer até no nível da interdisciplinaridade eu compreendo que seja possível para o indivíduo fazer e começar a compartilhar, agora quando você passa para nível hierárquico superior eu consigo pensar num cara que saiba física, química e biologia bem, consigo pensar num cara que saiba história e língua, que saiba língua e física, que saiba língua e química, que saiba, então pensar nas habilidades humanas individuais como estou falando da efetivação dessas coisas na sala de aula, eu consigo ver um professor que ele aceita a sua limitação na profundidade em troca da extensão, mas eu não posso fazer tudo, a construção da transdisciplinaridade nesse sentido que eu estou falando, acho que ela é um problema de organização social da escola muito mais amplo, não basta ser um professor, tem que ser a escola inteira, o princípio da escola, isso acarretaria, aí então eu volto para um problema prático, construção de currículo, que currículo transdisciplinar é esse, como se faz junto, é um pepino, tá certo? É bonito falar da complexidade, papapaa, mas a hora que você vai 
meter a mão na massa a construção neste sentido, em que os indivíduos se apropriaram das conexões entre as disciplinas, trabalham de maneira coletiva sinergética e organizada e a escola funcione de maneira transdisciplinar com um currículo que revela isso, com os alunos que aceitem isso, numa sociedade que aceite isso, tudo bem, você fala beleza. Assim como eu acho que os PCN são uma beleza, agora a transversalidade que eu entendo como interdisciplinaridade, a minha tentativa de fazer formação é na construção de subsídios a formação de professores para a implementação da interdisciplinaridade na sala de aula, tem ver com essas exigências dos PCN de transversalidade, que os professores falam o que é isso? Como é que eu faço? Eu não sei como é que eu faço? Como é que você quer que eu ensine física e biologia, eu não sei biologia eu só sei física, então a pergunta é essa e o professor, como isso entra na formação do professor, imagino que você vai ouvir dos professores outra informação, pó esses caras baixaram esses PCN aí, eu não sei fazer, ou então quando o cara diz que está fazendo, são multidisciplinaridade.

V - Agora, por exemplo, a escola de educação básica de Ensino Médio, ela não teria também que ter mais a formação do indivíduo, não estou dizendo que ela não deva se concentrar muito em disciplinas, mas pensar mais na formação do indivíduo.

$\mathrm{P}_{4}$ - Então, mas eu preciso olha eu sempre quando penso em currículo em formação dos alunos eu penso intermediário no mediador disso que é o professor, quer dizer se eu não tiver um professor que tenha a clareza dos critérios axiológicos, epistemológicos e antológicos daquele recorte feito daquela seleção de conteúdos, ele está fazendo uma reprodução ou alguém que escolheu e ele está reproduzindo aquilo de alguma forma, que é a história da educação no Brasil, né?

V - Aqui cabe principalmente a história do vestibular.

$\mathrm{P}_{4}$ - No caso do Ensino Médio sim, mas na educação como um todo das classes dominantes, do ponto de vista político, você olha para a educação do ponto de vista político a reprodução dos conteúdos e o tipo de formação está mais ligado às necessidades das classes dominantes do que a de uma distribuição democrática das necessidades sociais para a formação do indivíduo, então você fala bom, a gente estava no Ensino Médio, cuja formação pressupõe-se disciplinar, quando vou para o professor de ciências, o que é o professor de ciências? É a formação limitada, aliás, toda licenciatura em ciências, só que a maioria delas foram em caráter multidisciplinar.

V - A "UFA" está com um projeto assim

$\mathrm{P}_{4}$ - É essa coisa maluca que está aí na "UFA" agora, essa é uma coisa boa para você olhar para o seu trabalho, tudo bem eu estou falando em interdisciplinar como se forma um cara interdisciplinar, é essa a licenciatura? Eu tenho minhas dúvidas. Agora quando você vai para o Ensino Fundamental I, quem é a tia? É a que sabe tudo.

O pessoal que da aula no Ensino Fundamental tinha que ter o melhor salário, porque o campo de extensão que elas tem que cumprir é imenso, e lá não é só o campo de extensão do ponto de vista do conteúdo é o campo de extensão ético, estético e é o mundo. Tinha que ter três professores por sala para dar conta, não era um. Então, eles deveriam ganhar muito dinheiro, porque para se chegar ao ponto de se conseguir dar uma aula sintética como 
aquela, sintética no sentido da síntese desta extensão, essa pessoa demorou para se formar "a rodo", só que não, inverteu-se, preferiu-se a extensão à profundidade no sentido de valores complementar, então a professorinha lá sabe tudo? Não ela sabe tudo sobre nada ou nada sobre tudo, ela sabe nada sobre tudo. Todo mundo considera ela assim, superficial, a tia, aí é fácil, porque a escolha fica clara na escolha da escola, que é a escolha disciplinar, no sentido de que a medida que você avança no nível de ensino mais disciplinar você se torna.

V - Porém, especialista.

$\mathrm{P}_{4}$ - Isso.

V- Agora o que se faz muito é uma crítica a interdisciplinaridade na questão de generalização e especialização, aí tem esse problema?

$\mathrm{P}_{4}$ - É disso que eu estou falando, quer dizer, o jogo está e se chama princípio do balanço complementar, mas é a idéia do Morin isso daí, não é do Morin desculpe é do Varela, está ligado a isso, entre esse compromisso de profundidade e extensão, tem que ter isso. A superficialidade está na falta de profundidade e na extensão, o cara quer falar de biologia e montou um livro didático de matemática que falava de um box de interdisciplinaridade, tubarão tem 36 dentes, sei lá, doze camadas de dentes a primeira tem 30 a segunda tem 25 , pronto aí em séries numéricas de 36, o que é isso? Nesse sentido é de uma superficialidade de não saber que ela é superficial, se você entende a interdisciplinaridade, quer dizer eu diria que não é superficial a interdisciplinaridade, eu diria que não é interdisciplinaridade, que para ser você precisa dominar a parte do outro conteúdo.

\section{V - Quer dizer desce e sobe?}

$\mathrm{P}_{4}$ - Então não é só desce e sobe é desce e anda pra frente e sobe, a profundidade e a extensão desse conhecimento e está ligado ao recorte, que fazemos na "CGC" e se você não faz de maneira responsável, você está fazendo de maneira irresponsável, ou seja, você não se compromete, você não se co-responsabiliza com a escola, você não se co-responsabiliza com formação do sujeito, não se co-responsabiliza com as suas escolhas, ao meu ver é um negócio complicado.

V - Professor, e esse novo artigo como eu faço para entrar em contato?

$\mathrm{P}_{4^{-}} \mathrm{Ah}$ ! eu posso passar para você, não é novo, na verdade ele foi reescrito, foi enxugado, ele agora está bem fortalecido do ponto de vista da, eu posso passar para você, por e-mail, depois.

$\mathrm{V}-\mathrm{P}_{4}$, obrigado pela disponibilidade. 
Entrevista: $\mathrm{P}_{5}$

Data: $25 / 05 / 05$

Tempo Total: $45 \mathrm{~min}$.

$\mathrm{V}^{36}$ - Sobre o trabalho que nós temos que desenvolver, eu estava pensando em falar sobre os projetos de trabalhos do Fernando Hernandez e a sua aplicabilidade no Ensino Médio, que o você acha?

$\mathrm{P}_{5}{ }^{37}-\mathrm{Eu}$ acho que o Hernandez tem razão em apontar que a escola se organiza quase que exclusivamente disciplinarmente você vai ver como é que uma escola funciona, então são tantas aulas dessa matéria, tantas aulas daquela, assim né. Então, a crítica é feita a isso e a defesa é feita quanto à existência de, a defesa da necessidade é da existência de espaços, para a realização de projetos, [que é onde se explicitam objetivos, metas, as razões pelas quais estou estudando aquelas matérias], (1) [porque a matéria é meio para eu atingir alguma coisa]. (2) Então, é preciso haver espaço para o projeto e em geral os projetos são realizados paralelamente à organização da escola é como se fosse uma coisa à parte, o extra!

\section{V - E aí viram "projetinhos".}

$\mathrm{P}_{5}$ - Aí é sempre interessante tudo que se faz extra, mas não entra no funcionamento orgânico da escola, então é assim que eu entendo a crítica que ele faz da disciplinaridade da escola. Agora, [o desvio é a gente pensar que agora acaba a disciplina], (3) não é isso, a organização da escola precisa prever espaços aula, que são acho [os espaços mais importantes da escola], (4) [mas precisa ter espaços maiores, espaços de tempos maiores do que o da aula], (5) eu digo espaços de tempos maiores porque um projeto, por exemplo, não se realiza no tempo de uma aula nem no espaço de uma aula; o projeto é uma coisa que a gente busca fica um mês ficam dois, fica o ano inteiro realizando, só que isso tem que ser administrado, gerenciado ao mesmo tempo em que há as aulas.

$\mathrm{V}$ - Seria praticamente alternando isso, combinando isso?

$\mathrm{P}_{5}$ - É deve ser uma coisa combinando, não é saltar de um pro outro e do outro para um, isso tem que ser combinando ao longo da semana tem que ter espaços para tudo isso e eu acho que como [o projeto traz assim à tona a questão fundamental da articulação entre o pessoal e o coletivo em todo projeto que existe esta articulação entre o interesse pessoal e o interesse coletivo.] (6)

$\mathrm{P}_{5^{-}}$Quando se faz um projeto não são quatro ou cinco pessoas não é que todo mundo está fazendo a mesma coisa, [todo mundo está buscando a mesma coisa, mas cada um está realizando uma tarefa diferente uma tarefa pessoal senão não é o projeto é dividir uma carga entre cinco pessoas, cinco pessoas estão fazendo um projeto cada uma está participando de um jeito mais está buscando uma meta comum.] (7)

\footnotetext{
${ }^{36}=$ Refere-se ao entrevistador: Valdir Pedro Berti

${ }^{37}=$ Refere-se ao entrevistado: $\mathrm{P}_{5}$.
} 
V - Mas cada um dentro do seu projeto

$\mathrm{P}_{5}-\mathrm{E}$ agora, como necessariamente o trabalho com projeto a idéia de projeto traz à tona esta articulação a questão da articulação entre o pessoal e o coletivo, [a questão da pessoa aparece muito e o espaço da aula nem sempre é adequado para essa relação pessoal] (8) é claro que há relações pessoais durante a aula, mas [a gente precisa de um espaço como esse em que a gente está conversando aqui.] (9)

\section{V - E a escola infelizmente não tem.}

$\mathrm{P}_{5^{-}}$Então, [a escola precisa de espaços maiores do que o da aula, o da aula é o mais importante, mas tem que ter mais do que a aula e tem que ter menos que a aula, isso o que a gente está tendo aqui essa conversa é um espaço de relação interpessoal], (10) que é o espaço de conversa, orientação, tutoria, ou outros nomes, mas, é um espaço de tempo de um a um, pode ser cinco minutos, mas na hora certa aquela conversa pessoal produz mais do que, às vezes, assistir a muitas aulas sobre um determinado assunto. Então, é a combinação desses três espaços que precisa estar presente na escola, a aula, o mais que aula que pode ser o projeto não precisa ser tudo em forma de projeto, você pode ir regularmente numa escola e ter a literatura como foco, o teatro, o cinema ou outras coisas assim. Quer dizer sai para assistir a um filme, quer se chame isso de projeto ou não, mas na volta, conversa, analisa, trata disciplinarmente o que foi visto, examina disciplinarmente e se conversa sobre isso, é conversa, fora da interrupção da aula.

$$
\begin{aligned}
& \mathrm{V} \text { - Como se fosse aquela coisa obrigatória? } \\
& \mathrm{P}_{5} \text { - Então, é esse o ponto. }
\end{aligned}
$$

V- Na questão da escola de Educação Básica, como Educação Básica é posta hoje, você, pensa que seria a otimização desse tempo que já existe, por exemplo, como fazendo essa combinação, ou o você acha a necessidade de isso daí não dá, para você combinar as duas coisas, nós temos que passar então, por exemplo, aulas no período da manhã teria que ser no período da manhã e tarde para esse tipo de trabalho ou não isso poderia ser combinado?

$\mathrm{P}_{5^{-}}$Olha na [Educação Básica eu acho que se fosse possível a gente ter a escola de tempo integral isso seria altamente desejável], (11) o aluno poder passar o dia na escola, mas seria uma tragédia, acho, passar o dia assistindo aula, isso é horrível, fazer o aluno detestar a escola se sentir preso e amarrado, para isso daí precisaria ter atividades para o dia inteiro, claro que não se pode obrigar as pessoas a conversar, por exemplo, havendo espaço que viabilize essa conversa não significa dizer que a pessoa é obrigada naquele horário a ir à escola conversar mais se há um espaço, tal dia a tarde, o professor está disponível; então, se o aluno precisa ele vai se ele não precisa ele não vai, não é uma coisa para obrigar, como um cartão de ponto para as pessoas ficarem o dia inteiro na escola, [mas de modo geral as pessoas ficam pouco tempo na escola, agora tem aula demais], (12) mesmo ficando pouco tempo na escola tem aula demais, se for para aumentar a presença na escola, associando isso ao aumento do número de aula aí não acho legal, agora se aumentar a presença na escola, quer dizer justamente viabilizar esses espaços maiores e menores, poder sair com 
aluno para [uma excursão, tempo previsto no horário para isso, passar o dia, poder também encontrar, sem hora marcada e conversar, cruzar um aluno com o professor na biblioteca procurando livro e conversar, precisa haver espaço para isso.] (13)

$$
\begin{aligned}
& \text { V - É isso que falta. } \\
& \mathrm{P}_{5} \text { - Falta muito. }
\end{aligned}
$$

$\mathrm{V}$ - Na questão de projetos, me parece não sei se é, ele pode ser disciplinar ou interdisciplinar, tenho lido algumas coisas sobre interdisciplinaridade e me parece que, não sei, está tentando ligar, por exemplo, o que estamos vendo na disciplina na nossa disciplina e o que a literatura tem recomendado o que tem falado sobre o assunto e eu não sei se estou interpretando errado, mas me parece que quer você fique no eixo mult, inter, me parece, que você amplia, você está ampliando uma visão maior e até interessante, mas continua na disciplina, me parece que você tinha um objeto que era disciplinar e agora você está dizendo o seguinte: você está ampliando meu espectro de olhar.

$$
\mathrm{P}_{5} \text { - [de relações, de olhar, mas continua na disciplina.] (14) }
$$

V - Isso, não vou dizer que é um erro, mas ainda a gente não fica nas disciplinas?

$\mathrm{P}_{5}$ - Sim, [mas veja não é o caso de pensar que vão acabar as disciplinas, ] (15) ou [que vão cair às disciplinas de sempre, o eixo multidisciplinar, interdisciplinar, esse eixo tem que estar em si, o trabalho da escola em grande medida é um, trabalho disciplinar, com algumas propostas multidisciplinares sem relação com as outras disciplinas]. (16) Agora [a seta aponta no sentido da interdisciplinaridade] (17) quer dizer, [no incremento das relações entre as disciplinas, quer dizer, o que não é razoável é as disciplinas trabalharem sem se relacionar] ou com fracas interações que é o que mais freqüentemente acontece, [então o que se busca é esse aumento nessa interação.] (18) Agora [nem tudo se resolve nesse eixo disciplinar, a gente precisa daquele outro eixo intra, trans,] (19) onde num sentido você diminui, [ainda mais o objeto da disciplina, e afunila e põe uma lupa. No intra você aprofunda e essa aprofundamento leva ao isolamento do especialista. Neste sentido o afunilamento leva a uma disjunção dentro da própria disciplina], (20) [mas no outro sentido é aí que é um eixo você amplia o objeto] (21) e olha para aquelas "coisinhas" que está vendo numa perspectiva maior, é um verdadeiro cone, esse outro eixo, um cone, assim no sentido de você olhar aquelas miudezas assimiladas, mas olhar em uma perspectiva mais ampla, vendo o sentido daquilo, no exemplo da biologia, do mapeamento genético e as questões de ética que aparecem, nos exemplos, da física, de pensar em, da física ou da química na estrutura mínima da matéria pensar no que é essa realidade, a realidade como algo pronto, como algo construído, a realidade com o produto de uma construção racional mental, o Menezes, você conhece, lá da física, publicou um livro há três ou quatro semanas, é interessante, o Menezes é muito bom de palestra, de tudo, mas ele escreve muito menos do que ele poderia, ele é muito ativo, entende, mas ele parou direitinho e ficou, acho que seis a sete anos e escreveu um livro muito bonito chamado Matéria: uma questão de espírito, é um livro muito interessante, onde ele examina de um ponto de vista elementar, da perspectiva da escola básica do professor de escola básica, a concepção de matéria à imagem da matéria, partículas e tudo mais; [então aí é que se vê não é que tem que proibir 
esse afunilamento mas tem que ter a grandeza para olhar essa coisa numa perspectiva, esse é o eixo que no geral falta porque a escola fica exclusivamente no da disciplina,] (22) mas voltando para o mesmo ponto, [não se trata de dizer assim acabam as disciplinas, não é isso.] (23)

V - Seria possível, ou pelo menos correto pensar que quando eu vou pelo eixo da trans eu levo em consideração mais a questão das pessoas?

$\mathrm{P}_{5}-$ Sim com certeza.

V - Essa é a minha dúvida se os professores no geral, quando falam em trabalhos ou de inter e até comentam sobre o eixo intra, trans, que no geral eles estão falando, conseguem perceber essas diferenças. Se você está no eixo mult, inter tenho um trabalho muito interessante, eu amplio, mas ainda estou no eixo dos objetos?

$\mathrm{P}_{5^{-}}$[dos meios, não dos fins.] (24)

V- O professor acha que isso está acontecendo ou não?

$\mathrm{P}_{5}$ - Claro, está perfeita sua análise, [permanecer no eixo mult inter, é permanecer no nível dos meios, das disciplinas como um meio,] (25) sem estar se detendo sobre os fins, que em última instância são as pessoas, quer dizer, quando você procura, por exemplo, [um tema transdisciplinar, o primeiro que aparece é a educação, claro que você pode pensar na antropologia, filosofia, todos esses temas que tem o homem ou a pessoa o ser humano,] (26) a pessoa em termos sociais assim como centro podem acabar derrapando para o nível da disciplinaridade, o sociólogo, o antropólogo, o filósofo tratando da sua disciplina com um interesse puramente disciplinar, agora é uma derrapada, quando a gente pode se pensar praticamente em qualquer disciplina em termos assim transdisciplinares, [mas o que eu acho que o que há de comum a todas essas formas de pensar é colocar o ser humano no centro das atenções; isso é o que há de comum a todos esses exemplos de transdisciplinaridade, seja educação, seja filosofia, antropologia etc.] (27)

V - No livro "educação projetos e valores", você faz uma pesquisa sobre isso, é um material trabalhado me parece que é um congresso, parecia essa percepção dos professores já ressaltando a necessidade de conduzir, por exemplo, esse trabalho integrado para as pessoas, você tem essa percepção ou não estão ainda no eixo mult inter e ficam por ali mesmo?

$\mathrm{P}_{5}$ - Eu acho que não é explícito é uma coisa tácita, mas há insuficiência do eixo inter-multi disciplinar, essa insuficiência os professores sentem, quer dizer eles sentem que falta alguma coisa, agora não é que se diz explicitamente; não! Precisa da trans, ou precisa por o centro nas pessoas, mas a insuficiência nesse eixo eu acho que é o que aparece nas conversas, nos contatos, e mesmo [o apelo que a palavra interdisciplinaridade tem, atrás, é um apelo muito forte, justamente por que ela promete a trans na verdade, o jogo de palavras aí não importa muito, mas promete ir além da minha disciplina,] (28) mas ir além da minha disciplina no sentido de levar em consideração a dos outros e articular, bem ainda é pouco, 
[é preciso ir além de qualquer disciplina, pensar na pessoa não como a ação de disciplina ou situação de disciplina,] (29) mas sempre dar um apelo, o sistema é sempre muito bem recebido, o professor corre atrás, aí não quer dizer que corra atrás de uma quimera, de uma coisa que não tem muito a ver.

\section{$\mathrm{V}$ - Intuitivamente ele procura isso?}

$\mathrm{P}_{5-}$ [Ele procura isso, acho. Ele pode não ter a consciência explícita, mas intuitivamente ele procura convergir para as pessoas.] (30)

$\mathrm{P}_{5}-$ Agora, no fundo, o fundamento mesmo para consolidar essa perspectiva de investigação, de estudo, não pesquisa formal, empírica que está observando, mas pesquisa de estudo de investigação, o fundamento para essa visão é o Ortega e Gasset, é Marias. É o pessoal que trata da educação nessa perspectiva, é a pessoa. Ortega no fim do século passado, início desse século 1916, 1920, Ortega está escrevendo bastante sobre isso.

\section{V - Quer dizer que no geral ele finaliza para as pessoas.}

$\mathrm{P}_{5}$ - Há é claro outras pessoas como, por exemplo, o Munier, com o personalismo. Munier, o filósofo que morreu muito cedo, claro que poderia ter produzido muito mais, mas o Murnier surge numa época 1940 a 1950 em que o grande embate está se dando entre o Individualismo do Existencialismo e o Marxismo; então o existencialismo de um lado e o marxismo do outro.

O existencialismo, mais ou menos, com a mensagem de que o que existe é o indivíduo, estamos aqui abandonados à própria sorte, não há enfim, essa super estimação do indivíduo, assim sem projeto, sem rumo, entregue à própria sorte, e por outro lado, o marxismo com visão completamente oposta, numa história que tende para um lugar de predomínio do coletivo sobre o individual e a infra-estrutura econômica moldando, pré-figurando a cabeça das pessoas, sua estrutura ideológica, então nesse embate entre o individualismo de um lado, o existencialismo de um lado e o marxismo de outro, surge o Murnier como um terceiro, e diz olha, o individualismo "tô fora", o Personalismo que é a pessoa no centro, agora a pessoa não existe sem a sociedade, as relações sociais, uma pessoa é um feixe de relações sociais; então, não dá para separar e daí a idéia do personalismo do Murnier é muito interessante, agora ela foi muito subestimada ou contaminada pelo cristianismo do Murnier, porque ele era, a perspectiva era totalmente distante, exemplos muitos assim ele dava pensando no caso das religiões ele teria levado isso ao ápice do cristianismo, onde o próprio Deus transforma numa pessoa, vem para cá, é a única religião onde acontece isso quer dizer o próprio Deus é que transforma numa pessoa e habita entre os homens, e aí quem não vai por essa vertente, não é cristão ou não acha que a resposta a essa pergunta deva passar pela religião deixa de lado, mas é um exercício interessante ler o Murnier, esquecendo da perspectiva cristã dele, o que sobra muito, acho que o que sobra é o fundamental de colocar pessoas no centro das atenções e tudo, quer dizer é um exercício rico ler o Murnier, deixando de lado isso.

A gente tem uma coisa do mesmo tipo com Pascal é um filósofo notável.

$$
\text { V - O próprio Morin cita Pascal. }
$$


$\mathrm{P}_{5}$ - É Pascal é notável e ele se contrapõe à Descartes, Descartes é a separação nítida razão e emoção, razão sentimento e Pascal é o que afirma o coração tem razões que a própria razão desconhece, então me parece que todos são mais simpáticos a essa perspectiva de articulação razão e sentimento, por outro lado, Pascal era um religioso convicto e que na maior parte da vida, na maturidade era sectário até ele tinha, ele participava de uma espécie de seita (os diatenistas), sabe quando tem um ramo assim do cristianismo, do catolicismo bem marcado e a isso contamina muito, porque ler o que ele está escrevendo a luz disso. Com isso, ele se isolou e tudo, então, a influência de Descartes é muito maior do que de Pascal, mas qualquer um que leia o que Pascal tem uma simpatia grande, sente que a gente, a como pessoa está mais para Pascal do que para Descartes.

V - E aí não entra nada como religião?

$\mathrm{P}_{5^{-}}$Depende de como se lê e depende muito também de não se ter preconceito, idéias preconcebidas, porque hoje a gente vive uma situação oposta, quer dizer parece que quem quer que fale sobre religião não é sério, é uma inversão, de perspectiva, assim não dá para ser assim, sem preconceitos de um dos dois lados, duas visões de mundo duas maneiras de caminhar, que tem que ser, duas maneiras de pensar a realidade tem que ser considerada nenhuma delas é a priori, um absurdo.

V - E também não se exclui.

$\mathrm{P}_{5}$ - É também não se exclui.

V- .... quanto à educação no século XXI, a educação do século XVIII, XIX e XX começa a ter problemas a gente percebe, mas a educação no século XXI, mudando rompendo com alguns paradigmas desse século, seria de certa forma resgatar essa questão da pessoalidade?

$\mathrm{P}_{5}-\mathrm{Eu}$ acho que sim, agora o nó é como resgatar isso e fundar uma ética, porque a perspectiva religiosa é fácil fundar uma ética na perspectiva religiosa, fundar quer dizer dar o fundamentado para os princípios, fora da perspectiva religiosa, quem tentou e não foi bem sucedido, por exemplo, Kant funda, mas ele funda com uma confiança que se mostrou exagerada na ciência, na razão científica, no fim do século XIX, início do século XX, com a nova física com crise no fundamento da matemática; então aquela confiança na razão científica teve que ser transformada a razão mudou e hoje não é possível ler Kant, quer dizer é o maior edifício que a gente tem, do ponto de vista da constituição ética, mas não é possível ler sem repensar o que é mesmo a razão, o que é mesmo a ciência, porque aquilo mudou; agora Sartre não chegou a uma ética né; assim, agora para mim hoje atualmente nesse momento estou super curioso comprei, até o livro no ano passado, que saiu no fim do ano passado, um livro do Morin chamado ética, saiu ética do Morin em francês comprei imediatamente, ainda não cheguei a uma conclusão, li pedaços e agora eu vi que saiu rapidamente em português, o livro dele e a gente compra em francês é muito mais caro, saiu em português eu li no jornal.

$\mathrm{V}$ - Para mim, me parece que ele tem sido um precursor desse debate. 
$\mathrm{P}_{5}$ - É exatamente, desse debate, então eu digo é uma grande curiosidade ver como é que ele fecha, porque a ética do Morin é o volume seis do Método.

V - Que vem justamente contrapor ao Descartes.

$\mathrm{P}_{5}$ - Isso; então, é um método, tem O Conhecimento do Conhecimento, A natureza da natureza,...Vida da Vida são seis volumes, o sexto é a Ética e é o último que fecha, vou ver como o ele fecha esse balanço aí, esse é o grande desafio, porque por pessoa no centro, mas o que controla a pessoa, o que regula, ou que normatiza a pessoa.

V-Sem ser dogmático?

$\mathrm{P}_{5^{-}}$É sem ser a religião, então que tipo de transcendência, de coisa além da pessoa regula a pessoa?

V - Esse é o nó?

$\mathrm{P}_{5}$ - Isso, esse é o nó. Então, não saberia te dizer qual é a resposta do Morin, vi o livro, já folhei, mas ainda não vi qual é a resposta do Morin.

V - Mas, a educação do século XXI, ela caminha para isso.

$\mathrm{P}_{5}$ - É exatamente, esse é o mote.

$\mathrm{V}-\mathrm{P}_{5}$, obrigado pela disponibilidade, por esse espaço, tão necessário na escola básica e que nós podemos desfrutar na pós-graduação. 
Entrevista: $\mathrm{P}_{6}$

Data: $14 / 09 / 2005$

Tempo Total: 43 min.

$\mathrm{P}_{6}^{38}-(\ldots)$ Quando você escreve você articula o pensamento, quando você fala, você não necessariamente consegue articular o pensamento, e aí quer dizer, ele vai se articulando à medida que você vai falando; então a idéia geral ela é importante, mas às vezes, nem sempre uma frase fica descontextualizada, é só um cuidado para você. Eu não tenho nenhum problema com isso, não é só com essa, mas com todas as entrevistas. A análise da entrevista que a gente faz, ela é sempre um recorte, ela tem que ser feita mais no geral do que na fala expressa de uma frase, ou de uma palavra específica.

$\mathrm{V}^{39}$ - Eu vou tomar o cuidado, mas então $\mathrm{P}_{6}$, a questão é, quando você participou desses documentos, mesmo que tenha a postura da professora, que vamos discutir em seguida, mas quando se fala em interdisciplinaridade, eu vou me fixar na interdisciplinaridade, mas aparece muito contextualização e interdisciplinaridade; enfim o que se propõe com isso?

$\mathrm{P}_{6^{-}}$Então, eu não sei se eu posso falar o que se propõe ou o que eu entendo dessa proposição, por que é assim. Eu acho que isso é um pouquinho do histórico de como foram elaborados esses parâmetros. Quando nós fomos [convidados para fazer esses parâmetros, nós fomos convidados, também para fazermos o de física, não o de química, nem de biologia e sem nenhuma orientação maior sobre que é interdisciplinaridade, contextualização, nenhuma dessas palavras estavam no nosso vocabulário,] (1) [a primeira vez que nós fizemos a proposta, é eu acho que o $\mathrm{P}_{3}$ foi convidado muito mais pelo seu histórico, pela sua participação, pela forma como ele atuava no GEPE e com o GEPI na química,] (2) como [esses grupos de certa forma significavam uma mudança de atenção de rumo de foco no ensino.] (3) $\mathrm{E}$ foi mais por isso que eles foram chamados, e nós participamos do que por uma digamos uma filosofia pré-estabelecida que incluísse ética, ou interdisciplinaridade, contextualização. Então, eu acho que é um movimento que vem de duas partes, uma que de toda a história que esses grupos tinham de atuar no ensino e o que diferenciavam esses grupos de certa forma era o que nós chamávamos de física do cotidiano, mas que agora tem um nome mais geral que é contextualização, [que é você tentar sempre partir dos objetos concretos, então, que dizer aquela física dos movimentos abstratos, você faz as coisas do cotidiano, do concreto do carinho que move, do acelerador do metrô, dos objetos do dia-a-dia, do telefone, das coisas do dia-a-dia para que você depois passa para cima, mas que você partisse do cotidiano mais imediato.] (4) Isso significava para muita gente e para alguns educadores e que depois surge essa palavra contexto, que dizer reter o contexto, ou seja, você não trabalhar um conhecimento desvinculado do seu contexto. Então, [contextualização eu acho que tem tudo a ver com que nós já fazíamos] (5) e que; tanto que foi muito fácil reescrever ou re-entender o que nós tínhamos escrito na primeira versão, que o contexto já estava lá.

\footnotetext{
${ }^{38}$ Refere-se ao entrevistado: $\mathrm{P}_{6}$.

${ }^{39}$ Refere-se ao entrevistador: Valdir Pedro Berti.
} 


\section{V- Quer dizer era uma prática}

$\mathrm{P}_{6^{-}}$Era uma prática que já existia, e até acho que tinha a palavra viu, se não me engano essa palavra já, éehhh, talvez não, depois ela ganhou um foco muito maior.

V: Virou uma palavra de moda.

$\mathrm{P}_{6^{-}}$É, mas ela já estava lá, quer dizer o contexto já estava lá. [Agora a interdisciplinaridade ela é um pouco mais complicada, e ela é muito complicada para mim também. Ela foi mal entendida no início, porque se entendeu que você queria no fundo substituir, trabalhar com as áreas. Como os PCN agruparam conhecimento em três áreas, a interdisciplinaridade parecia que ia criar um professor de ciências que da física química, matemática e biologia, então o professor dessas disciplinas.] (6)

V- Me parece que essa foi à impressão no inicio que pessoas tiveram.

$\mathrm{P}_{6}$ - Essa foi a impressão e que um desastre, que nós, é por isso que eu estou dizendo, eu não sei o quanto eu posso dizer para você. [O que estava nos PCN e o que estava na nossa idéia; porque de novo, quero dizer, os PCN são escritos pelas áreas e têm um discurso que o discurso de propostas da Secretaria do Governo, do MEC, etc.], (7) que é discurso que você pega lá os primeiros capítulos etc. Lá nos PCN, eu só vi depois que eles foram publicados. [Nós nunca tivemos conhecimento deles antes para fazer os PCN,] (8) tem coisas ali que se articulam, você vê que está ali e tem a ver, mais eu posso responder pelo que nós entendemos por interdisciplinaridade, exatamente, eu acho que foi essa confusão de achar que iam se suprimir todas as áreas ia ficar com interdisciplinaridade como uma figura de construção disso aqui.]

\section{V- E você tendo áreas?}

$\mathrm{P}_{6^{-}}$É você tendo um professor de área. Eu acho que jamais passou pela cabeça de nenhum de nós uma coisa dessa, mas isso é uma leitura que alguns fizeram. Eu acho que foi conveniente até a certas Secretarias da Educação fazer, porque você simplifica um pouco o processo, você simplifica um pouco a escola, etc. Acho que algumas Secretarias da Educação até chegaram a cogitar de coisas semelhante, isso vem apoiado, essa cogitação de coisas semelhantes, deixe eu fazer um parênteses, depois eu volto aos PCN. Ele vem apoiado por uma coisa, que você podia tentar descobrir, acho que eu não tenho mais acesso a esses documentos, mas na Secretaria do Estado de São Paulo, éehhh, naquela época, éeeeh, bom , estava começando um movimento desse sistema de avaliação internacional do PISA etc e tal. Isso por trás tem uma proposta que era do BID, para, o BID tinha atuado muito, é até meio controverso, porque o BID atuou muito na área de Ciências, mas [o BID tinha atuado muito nos processos, financiando projetos de educação, no Brasil, etc. e tinha uma proposta, e não sei até que ponto ela ainda hoje existe, ou não existe, mais, como é que é, em você atribuía a educação duas funções principais: domínio da língua e o domínio da matemática, então você centrava todo o conhecimento, quer dizer, as habilidades que você queria desenvolver em torno da língua, da expressão e da matemática; (9) tanto que você vai ver que os primeiros exames internacionais de comparação disso daquilo e daquilo 
outro, são sempre português e matemática, quer dizer, língua no português não era possível, mas você faz a língua na sua língua, inglês, espanhol, e não mais o que e a matemática e por trás disso tinha um pouco; assim, porque o resto é um pouco acessório, tanto é que você vai ver que o número de disciplinas, ah!!, o número de horas, de disciplina de português e matemática com isso aumentou em detrimento ao número de horas de disciplinas de física, química e biologia no Ensino Médio. Embora seja aberto, quer dizer, embora era assim; hoje cada escola escolhe, quer dizer tem uma certa liberdade para a escolha, mas essa liberdade segue certos padrões e os padrões que seguem em parte tem por trás ainda um pouco forte essa filosofia, que eu não sei sua origem, eu lembro de ter visto alguns documentos na época, mas não sei se e saberia localizar; Valdir, eu posso até procurar para você.

$\mathrm{V}$ - Nossa $\mathrm{P}_{6}$ seria muito interessante.

$\mathrm{P}_{6}$ - Porque eu acho que tem uma coisa interessante ver até que ponto, eu acho que quem estava por trás disso, era a "G N M", porque acho que tem uma questão, que não exatamente onde que pode buscar, mas tinha um discurso mais amplo, transcendia um pouco essa questão que era de fazer alguma coisa centrada em português e matemática. Ora, se você centra em português e matemática, você dá um, você diminui o peso das outras; então, quer dizer, nesse sentido a interdisciplinaridade vem quase que em decorrência dessa história. As áreas de ciências vão trabalhar juntas, mas no fundo você está privilegiando na proporia área de ciências muito a leitura e as matemáticas envolvidas naquela coisa, mas não nos conteúdos específicos de física, química e biologia que tivesse envolvido, acho que até você, não sei se daria para ver Valdir, eu não escreveria, porque eu não tenho certeza se aquele oficio, chama-se oficio do professor, não é um conjunto de material que, mas acho, que não é ainda interdisciplinar. É um material que foi produzido pela Editora Brasil.

\section{V- Eu conheço esse material.}

$\mathrm{P}_{6-}$ Eu não se por ali dá para ver se...

V- Ele tem uma proposta sim, realmente de trabalho diferente, me parece mais, juntando as disciplinas.

$\mathrm{P}_{6}$ - É, dá para ver se por acaso você olhar aquilo, ver lá por acaso como é que isso aparece nas propostas iniciais, nas falas iniciais, porque isso foi o primeiro movimento, éhhh, que acho que tinha, que G., (...) educação, embora ela não tivesse essa proposta, mas eu me lembro que, [as primeiras reuniões que nós passamos era até um pouco chocante para nós, a perspectiva de que por trás tivesse uma idéia de área,] (10) assim uma área com a interdisciplinaridade, assim, [muito mais forte que você suprimiria a área de ciências;] (11) assim, acho que podia tentar fazer, também uma leitura, não sei se provavelmente você já fez dos Parâmetros para ver o sentido que é dado, a disciplinaridade naquelas falas; nós já fizemos uma vez e eu fiquei surpresa, depois até, a gente pode até dar uma olhada. Fiquei surpresa porque, achei, analisando, falando agora dos primeiros capítulos, daquelas apresentações, até é um pouco contraditório em certos momentos, o sentido que é dado a 
interdisciplinaridade e é mesmo até hoje, porque interdisciplinaridade é uma palavra muito complicada. Então, acho isso.

V- Me parece, não sei não interpretei mas, não fica claro se ela deve ser feita a partir do professor ou entre professores, também, não é?

$\mathrm{P}_{6^{-}}$É nem se é para o aluno, ou não é ou se é, o que é, o processo, em que sentido. Agora, acho que, então isso é uma vertente do que está lá escrito que você deve dar uma analisada, uma olhada direitinho; e agora, assim, vamos lá ao sentido que tem de interdisciplinaridade, que faz sentido entre aspas, que a gente entende que faz sentido, construção da organização, inclusive, do trabalho do Ensino Médio, mas espere aí, antes disso tem o seguinte, a palavra interdisciplinaridade ela tem muitos sentidos como você já deve ter visto, tem pandisciplinaridade, multidisciplinaridade, transdisciplinaridade.

\section{V- Interdisciplinaridade cruzada.}

$\mathrm{P}_{6^{-}}$Àquelas todas, então nós estamos falando, vagamente do que seja interdisciplinaridade, que no fundo, no fundo não é nem interdisciplinaridade, se você for olhar essa não a interdisciplinaridade que a gente está buscando, não é? É uma outra coisa aí que nós estamos discutindo, ou enfim é um cruzamento de disciplinas do Ensino Médio, mas eu acho que não é interdisciplinaridade no sentido das definições, educacionais que se dão ou mesmo, não sei, na teoria do conhecimento mesmo, quer dizer o que é interdisciplinaridade, não é, [eu entendo que interdisciplinaridade seja uma coisa diferente, agora no sentido que tinha nos PCN, eu acho que esse sentido se aproxima muito de fato da contextualização que é você imaginar assim, os objetos do cotidiano são os mesmos para todas as ciências, então os olhares são diferentes,] (12) mas os objetos são os mesmos. Então [é importante que uma disciplina leve em conta o conhecimento da outra,] (13) leve em conta, significa, uma coisa muito delicada, não significa, no meu ponto de vista, que no instrumental da física, no instrumental da química, no instrumental da biologia tem que ser construído pelo aluno do Ensino Médio, certo? Eu sou a favor da disciplinaridade, no momento que você ao sair do Ensino Fundamental, você está agora, o ensino de ciências era um conhecimento, você estava defendo no fundo, deveria estar. No Ensino Fundamental a construção de pensamento cientifico em contraposição ao senso comum, ao pensamento religioso, ao pensamento histórico, etc. você estava construindo o pensamento científico, o raciocínio científico. Então, agora quando você, imagina uma formação no Ensino Médio, você está pensando especificamente na construção da disciplinaridade, que dizer, esse pensamento científico que é amplo, você já deu a ele uma idéia do que ele é, ele agora se torna Física, Química, Biologia e Matemática, não vamos deixá-la de lado.

V- Ou seja, como essas disciplinas trabalham nessa perspectiva do conhecimento.

$\mathrm{P}_{6-}$ E que são diferentes. [Epistemologicamente são diferentes; a maneira como a Biologia trabalha, a maneira como a Física trabalha, a maneira como a Química trabalha, isso eu acho que, no meu entendimento, por isso que eu acho que eu não sou a pessoa adequada, porque no meu entender.] (14)

$\mathrm{V}$ - É nesse sentido que a $\mathrm{P}_{6}$ defende a disciplinaridade. 


\section{$\mathrm{P}_{6}$ - É a disciplinaridade.}

V- Porque do ponto de vista das ciências do pensar da química, do pensar da física e da biologia eles são diferentes, é isso que você quer dizer.

$\mathrm{P}_{6^{-}}$[É isso que eu quero dizer, e eu tenho que construir a consciência diferença,] (15) ou seja, [eu só posso fazer inter, trans, dis, ou pan se eu tiver as disciplinas para perguntar, se eu não tenho as disciplinas para perguntar, eu vou fazer uma sopa, mas eu não tenho inter, nem trans, plus, nem cruzada.] (16) Eu primeiro, então, em algum momento, [ele tem que ter o cidadão, o aluno tem que ter o conhecimento de que o é, que trabalho, que olhares diferentes são esses que se complementam para olhar um objeto comum, que é o mundo a sua volta.] (17) [Tem um olhar da química, que tem uma metodologia de trabalho e tem uma forma de construção; claro eu não vou dizer para ele, tem uma metodologia de construção, mas eu vou fazer a física, fazer a química e fazer a biologia nestes atuar, nestas atuações diferentes, ele vai percebendo as diferenças de objetos, quer dizer, de forma de trabalhar o mesmo objeto. O mesmo objeto, natureza, sei lá o que você quiser chamar, o mundo ao seu redor em forma de olhar diferente.] (18) Então, [você tem que construir, porque se não você não pode fazer nem interdisciplinaridade, nem trans, nem multi., agora) nessa construção, ela faz muito mais sentido se houver um diálogo entre esses construintes e a interdisciplinaridade no meu ponto de vista nos PCN ela deveria aparecer como esse diálogo entre essas várias formas de construção.] (19 Então, se a gente agora, por exemplo, [está fazendo um levantamento aí, de energia, então, você pega a palavra energia, bom ela aparece na física, aparece na biologia e aparece na química, quando você imagina isso, quer dizer, olha esse conceito de energia que está aqui é o mesmo que a biologia trabalha, quando trabalha lá as quilocalorias, valor calórico, não sei o quê da fotossíntese, parara, pararaaa; é o mesmo que a química trabalha, no entanto, que é que nós fazemos, nós temos uma energia da química, uma energia da física e uma energia da biologia, e que não parece para o aluno de maneira a mesma coisa.] (20)

\section{V- Para ele, me parece que fica separado.}

$\mathrm{P}_{6}$ - São, são conceitos diferentes; e a maneira como os livros apresentam, você vai olhar mesmo, elas são completamente diferentes. Elas não, sequer nos livros, há possibilidade de você fazer essas pontes, entre uns e outros, porque eles são colocados, a ênfase que se dá é bastante diferenciada nessas coisas. Eu posso pegar um outro exemplo, velocidade é uma coisa interessante, quer dizer, velocidade você trabalha na física como velocidade é associada ao movimento de objetos, mas a velocidade de reação química, a velocidade de evasão, a velocidade da biologia, velocidade de crescimento, a velocidade são coisas, taxas, quero dizer, velocidade no sentido de taxa de variação do tempo que não seja necessariamente de espaço/tempo, elas não existem. Então, você tem um conceito de velocidade, que reduz a espaço/tempo, taxa de variação de espaço/tempo, quando? Não necessariamente pode ser espaço/tempo é uma taxa de variação no tempo, e como esse conceito de velocidade é mais amplo, ela aparece nas outras áreas também. [Então, eu acho que eu entendo a interdisciplinaridade que é uma coisa difícil de fazer, como a tentativa de você explicitar, ou de você conseguir trazer o diálogo entre as áreas] (22) desse ponto vista, [quer dizer, seu eu estiver dando velocidade e conversar com o meu professor de química, 
vou entender um pouco melhor quais são os elementos da velocidade lá da química que aparecem e que isso posso usar como exemplos no meu trabalho, ou devo usar como exemplos, devo trabalhar velocidade e crescimento, devo usar como situações, em que dou um outro sentido e nesse sentido é contexto também, dou um outro sentido para ao meu contexto, desde que eu olho os objetos que normalmente são características das outras ciências e não só da física; então, a física só trabalha velocidade como espaço/tempo, legal, mas não é isso que vou ver nas outras? Então, vou alargar esse conceito aqui de maneira que caiba também, as outras coisas e vice-versa, quer dizer, você teria que buscar essas pontes, de novo, quer dizer, são os conceitos comuns que aparecem em todas as áreas, por que nós estamos trabalhando com as mesmas coisas, mas que da maneira como elas são construídas hoje, elas parecem para o aluno coisas completamente diferentes e isso eu acho que nós temos, que é a interdisciplinaridade, seria isso.] (23) [Quer dizer, construir uma disciplinaridade que converse com as outras áreas, uma disciplinaridade que saiba reconhecer nela os elementos das outras que é muito difícil, porque nós não sabemos, porque que na biologia aparece, nem na química e nem na física, isso é um desafio e certamente não é para o aluno, é para o professor e é para a tentativa dos professores trabalharem isso daí.] (24) Deixe essa idéia de lado aqui, que já volto nela, acho que ela é um sentido ai que ainda porque poderia aumentar um pouquinho o exemplo, acho que isso aqui, já trabalhei um pouco na área da interdisciplinaridade da física com a biologia então posso te dar, porque sou da área biofísica e na área de bioquímica dei muito tempo aula para biólogos etc., mas é eu quero dar uns exemplos melhores mas, em temos de construções de conhecimento, mas aqui tem um outro aspecto da interdisciplinaridade que acho que acabou sendo um aspecto é complementar e que no fundo é talvez menos, esse aqui seja o primeiro aspecto interdisciplinar, seria muito mais através disso que nós estamos falando, quer dizer do conteúdo, e do contexto mesmo, porque na medida em que você estabelece objetos comuns você está dando um contexto e esse contexto é respeitado como um contexto comum tendo por todas as disciplinas, e isso, claro com o Ensino Médio limitado, você vai ter que fazer seleção, você não vai ter tudo que você vai trabalhar, mais algumas coisas que você trabalhar e conseguir fazer transpor em algumas coisas, você já vai abrindo espaço para essa, para esse olhar sobre o objeto que seja mais é mais, não vou dizer harmônico, mais , mais complementar, e não tão estanque como era antes, mais não interdisciplinaridade.

V- Você acha que, por exemplo, como a Educação Básica hoje está disposta, número de aulas, professores, e aqueles de HTPC, que existe, existe semanalmente ali, duas horas, vamos colocar duas horas para o professor. Seria nesses momentos então que o professor possivelmente poderia pegar esses conteúdos assim, que são conteúdos assim da química, da física e da biologia e eles conversariam entre eles a forma de trabalhar. Seria nesse sentido? Ou a você acha que...

$\mathrm{P}_{6^{-}}$Conversariam como fazer, tá porque acho que isso aqui é, então vamos entender o seguinte as diretrizes elas são é, isso aqui são diretrizes porque separadas por quatro diretrizes. As diretrizes apontam em direções, então isso aqui é uma critica que muita gente fez e sempre faz quando você diz é mais é vem de cima, vem de baixo, quem constrói, quem não constrói como é que é, não é possível em educação e é verdade, quer dizer, o que as diretrizes fazem é apontar direções. Apontar direções é um pouco de metas utópicas, coisas que você quer chegar, o como fazer é uma construção por fazer (risos!), e essa 
construção tem que estar aberta, então ela tem que ser aberta, porque cada translocar da escola, cada secretaria, cada professor, não existe, sozinho não, mais cada meio vai ver uma maneira de trabalhar e não é, não só essa maneira não é a única como também ela pode prescindir de varias outras é varias outros aspectos que compõe a educação que não é só isso, então a interdisciplinaridade tem que ser entendida. Então como fazer é um desafio, agora esse como fazer tem um outro lado da interdisciplinaridade que era aquele que eu queria te colocar que não é exatamente o contexto mais que eu acho que acaba criando uma unidade diária e, portanto que acaba sendo importante a conversa entre as áreas e, portanto uma interdisciplinaridade que é do ponto de vista, que agente chamou, (quer dizer) o que depois veio a se chamar de competências e habilidades mais o que tem de comum as competências e habilidades da área de biologia, da área de química, de física e matemática quer dizer, as competências e habilidades dessa área elas diferentes das competências e habilidades da área de expressão, português, etc. que são diferentes da área (de história), da natureza delas então eu não lembro se isso, eu acho que no primeiro PCN de todos, no primeiro até posso ver depois, nós ate fizemos um, tentamos fazer um mapa comum em que você tem biologia, física, química e você tem uma certa, você teria que ter uma certa semelhança entre essas competências que estão senda criadas. Então a interdisciplinaridade, ela aparece aqui, e no meu sentido que eu acho que é um sentido muito mais do que o do contexto, que é o sentido dos objetivos pedagógicos que você quer atingir, então olha se a escola se fixa objetivos pedagógicos pra um certo conjunto, turma enfim eu quero trabalhar tal coisa, essa coisa aparece em comum e ela pode ser desdobrada não no conteúdo água, não é isso, é uma habilidade, seja ela de ler gráficos, ela vai aparecer na biologia, na química, na física e na matemática. Então se você, fixar objetivos pedagógicos comuns, os objetivos pedagógicos impõe uma interdisciplinaridade não pelos conteúdos, mas pelas competências que você pode estar desenvolvendo, quer dizer, você vai estar procurando desenvolver certas competências de observação, então de observação que são diferentes, mas você ta ligado numa observação quer dizer ela não precisa ser uma interdisciplinaridade temática, que se baseia num.

\section{V- Numa situação problema ou no contexto mas ela parte.}

$\mathrm{P}_{6^{-}}$Ela pode se basear em objetivos pedagógicos comuns e, portanto em competências e habilidades que você vai querer desenvolver, quer dizer esse duplo aspecto aqui, ele quer dizer, num aspecto do contexto, do conteúdo ele está muito mais ligado a contexto e no aspecto educacional ele está muito mais ligado a objetivos pedagógicos da área porque ai você tem uma área em comum mesmo e isso aqui nós nos demos conta muito ahhh ao fazer no trabalho depois, não nos PCN que não teve interação entre áreas, mas nos $\mathrm{PCN}^{+}$, porque na medida em que você foi trabalhando aqui você foi dialogando mesmo, foi um dialogo difícil entre essas áreas para verificar e nós realmente, talvez nem tenha sido tão claro no papel mais ta muito claro pra nós que existem competências comuns a área de ciências e que se você traduzir isso como objetivos, você promove uma interdisciplinaridade, porque vai ter professor trabalhando na mesma direção, embora com objetos diferentes. Eu acho que essa, agora como fazer? Bom, aqui meu caro é eu não tenho a menor idéia (risos!), não eu acho que é assim, quando você coloca uma diretriz é, você vai construindo, nós vamos ter que construir esses fazeres não existe já um fazer pronto, então isso vai ter que ser muito experimentado, e eu acho que toda essa discussão em torno da interdisciplinaridade vai levar, essa discussão em torno da interdisciplinaridade vai 
levando a possíveis construções, não existe uma só; então, vai haver alguém que faz um trabalho temático e que isso aaahhh, deu certo é muito importante vai ter um outro que não trabalha assim mas que trabalha de outra maneira, vai ter um dialogo entre o professor de química, de física, que sentam, ou entre professores de matemática e entre outros professores vai ter um dialogo sobre o material didático que já ta preparado um pouco mais e que pode ser aproveitado por dois, quer dizer, não há eu acho que não tem aqui uma formula mágica.

V- Não existe números nem formulas, as coisas vão acontecendo as vezes acontece.

$\mathrm{P}_{6}$ - E espera-se como tudo em educação não deve ser nunca uma coisa, uma receita e que as construções diferentes e entendimentos diferentes disso sejam, agora, onde que tem que eu acho que é o problema, e alias isso vale pra interdisciplinaridade como vale para o resto das diretrizes, porque não adianta você falar que você vai mudar que você não vai, o livro texto continua mais ou menos iguais, quer dizer, esse e fazendo e mudando eles são lentos eles, não se formam de um dia para o outro, agora o que eu sinto que agente não tem e que deveria ter e que é um problema seriíssimo é inclusive eu acho que põe em risco muito os PCN, as diretrizes etc. é uma forma de organização que permitisse a divulgação dessas experiências, a troca dessas experiências, quer dizer é um dinamismo maior, até tem mais de uma maneira muito pouco articulada em que eu ficasse sabendo, olha você em Tupã/SP fez isso, deu isso, olha o Olavo fez não sei o quê, quer dizer se eu tivesse um é, você se inspira na, quer dizer a pesquisa educacional ela é complicada, porque ela é muito complexa, mas a sua pratica educacional ela também é, e fica complicada de ser analisada por isso mesmo, mas ela se inspira em iniciativas diversas você reconstrói coisas que você já ouviu falar, não vai ser igual, mas é alguma coisa que você entra em sintonia com aquilo que você acha que te alimenta enquanto sugestão, enquanto idéia, e quando você entra em sintonia com alguma coisa que é que você já viu antes, até você cria coisas suas, mas também você entra ressonância com essa coisa. Então, eu acho que o que fazer teria que ser o que falta é essa possibilidade de estar divulgando é situações diferentes, tentativas diferentes de buscar essa interdisciplinaridade. Aquelas que dão certo e aquelas que não dão.

\section{V- O momento para socializar isso daí, trocar.}

$\mathrm{P}_{6^{-}}$Principalmente as que não dão certo, eu vou mostrar, uma aqui, aqui não deu certo, olha aqui deu certo, para gente conseguir entender o limite desse negócio, eu tenho um enorme preconceito contra trabalhos por projetos interdisciplinares.

\section{V: Por que? (risos!), porque o conteúdo fica sacrificado?}

$\mathrm{P}_{6^{-}}$Pois é, então eu acho que não precisa ser assim, projetos, mas eu acho que agente, já chego lá, é que eu acho que agente tem que buscar são formas diferentes de fazer e se você faz o projeto e da certo, legal puxa, é troca de experiências, eu acho que não da o outro diz que dá o outro que faz, legal, vamos estar construindo um sentido comum pra esse termo. O sentido está dado de certa forma, mas não está definido, ele é muito vago, ele é uma direção o que tem que ter é que a rede educacional do país precisa construir esse sentido, e esse sentido são fazeres. E se agente não tiver uma socialização dos fazeres fica 
muito difícil e hoje em dia o que nós estamos vendo é que não tem nenhuma socialização dos fazeres ou que ela é muito restrita, ou que ela encontra muito poucos canais (V- Eu acho que ela encontra muito poucos canais) e ai agente não tem essa riqueza que poderia ter nesse negocio.

V: Eu acho que no Paraná tem uma organização maior onde eles se encontram no recesso, eu não sei se é para realizar a formação, mas poderia ser o momento para.

$\mathrm{P}_{6^{-}}$Poderia até olhar o que esta acontecendo, como está acontecendo, o que acontece, eu acho que você tem já o primeiro, o primeiro movimento desse fazer, esse negocio todo eu acho que é uma preocupação de ser interdisciplinar mesmo que não consiga, e já tem uma fala maior de professor com outro, ainda que eles não tenham, não tenham nas suas práticas mudando muito. Eu acho que já tem na escola um certo reconhecimento de um professor com o outro, sabe, uma, não sei em que nível isso acontece na escola, é assim, o que nós temos em contato com a rede é através dos nossos alunos que são professores, ou dos nossos ex-alunos que viram professores, e o que eu sinto é que talvez o nosso viés seja muito limitado porque justamente esta por ex-alunos, quer dizer que já vieram de uma cultura diferente, mas eu sinto que a rede tem um, os professores se respeitam um pouco mais, se respeitam no sentido de bom, eu sei que ele faz física, eu sei o que ele é, o que ele ensina física que é a química é diferente, que biologia é diferente coisas assim, eu acho que tem um respeito maior. Isso já é o primeiro passo, digamos assim, quer dizer o processo é lento e você não vai esperar que aconteça coisas muito próximas eu acho que isso vai acontecendo no meio do caminho, não vai ser assim de hoje pra amanha todos viraram interdisciplinares, ainda bem, porque se não você caem riscos que são muito complicados, e isso que é fundamental, agente tem que construir um pensamento químico, tem que construir um pensamento físico e o pensamento biológico e tem que perceber que essas coisas são diferentes e que elas se complementam, embora eu não vou fazer um discurso sobre isso, isso tem que está na prática que ele vai está fazendo, mais adiante eu até posso fazer o discurso sobre isso, vou te dar lá nossa experiência com física, química e biologia que até da para fazer o discurso sobre isso, mas por enquanto eu acho que é o fazer disso que.

V- É algo tácito, é que ele vai compreendendo.

$\mathrm{P}_{6}$ - Agora me conta um pouquinho do seu projeto lá em Tupã só pra eu saber, pra eu poder argumentar a você porque que eu sou contra projetos (risos!).

$\mathrm{V}$ - O que eu percebi nesses dois anos porque é assim era uma idéia de um supervisor de ensino e eu fui convidado pra trabalhar como assistente técnico pedagógico do ensino médio na época. Então a proposta era colocar trabalhos por projetos, mas isso em todas as escolas, com todas as disciplinas.

$\mathrm{P}_{6^{-}}$É trabalho por projetos?

V- É trabalho por projetos, então, os professores, elegem um tema.

$\mathrm{P}_{6}$ - Elegem um tema. 
V- Que eles acham significativo de acordo com o contexto da escola deles, da realidade, enfim ai eles tentavam trabalhar em cima disso daí; o que eu posso.

$\mathrm{P}_{6}$ - Me da um tema de exemplo só pra eu saber o que um trabalho por projetos.

V- Por exemplo, é, eles assim é, Tupã se tornou instancia turística, então o que isso ia, para o cidadão tupaense o que mudaria e o que não mudaria para cidade.

$\mathrm{P}_{6}$ - Esse projeto eu acho fantástico.

V- Enfim, o cidadão tupãense teria que mudar o comportamento dele, a relação dele isso traria mais emprego ou não traria mais emprego ou não mais emprego para Tupã. Tupã tem termas. Então, o que eu depreendi desses encontros, então nós fazíamos um encontro, nós íamos até as escolas, está entendendo e é assim houve uma mudança, então, claro que alguns professores tiveram até um desequilíbrio grande, houve enfim, houve tudo quanto é tipo de professores, professores que resistiram, professores que acharam interessante, ai no final do ano nós fazíamos uns encontros, na diretoria pra socializar e ai nas escolas tinham um tempo para falar dos projetos, mas o que eu percebi assim, então tem, teve algo interessante, tem coisas interessante, mas é o que eu percebi assim na fala dos professores, nas nossas conversas eram, primeiro, a questão de conteúdo, eles acham seguinte que para de dar conteúdo que projeto não tem conteúdo, que não era essa a idéia, mas eu também não sei como fazer, mas era o conteúdo perpassar por isso daí, mas eu acho que isso é uma competência difícil do professor conseguir. Segundo são esses momentos de encontros, o professor acha o seguinte é que ele deve ter mais tempo de encontro, eles precisariam de mais tempo para discutir esse conteúdo, de sentarem juntos; a escola não disponibiliza, por exemplo, material suficiente, então tudo sabe, essas coisas que agente foi percebendo nesses dois anos que, tem coisas interessantes, tem, tem trabalhos interessantes, houve trabalhos interessantes, é mas houve também assim muitas dificuldades e até então a idéia do supervisor, mais do que a minha, era assim, fazer a interdisciplinaridade em todas as disciplinas, assim todos, trabalharem; ai depois com o tempo eu já vi que isso é um nó, entendeu, eu acho que não, acho que tem disciplinas que, que dá determinados temas ou assuntos ou situações problemas em que elas entram bem e tem disciplinas que não entram, você força, entendeu? Então essas coisas todas eu fiquei e ai eu falei, agora eu tenho que estudar mais, você entendeu?

$\mathrm{P}_{6^{-}}$Ai é legal. Então agora, olha vem lá, é assim, o que você está falando é exatamente o problema é um nó, exatamente esse é o nó, quer dizer, eu acho super-legal trabalhar com projetos nesse sentido, quer dizer o projeto mobiliza uma escola, mobiliza uma comunidade para dar um sentido pro conhecimento, porque ela vai lá, bom eu estou na minha realidade o que eu vou fazer nessa realidade que eu estou vivendo, então, nessa realidade que eu estou vivendo,como é que eu posso contribuir, inserir, estudar e fazer e ai isso mobiliza a escola inteira, claro que dentro deste projeto vai ter aspectos da química, aspectos da física, aspecto da biologia, cada um vai descobrir lá, sei lá, nas termas, onde for que cada um vai poder se inserir, e ai, primeiro, tem um grande problema é descobrir a competência que o professor pode ter pra se inserir e fazer esse trabalho, que é um nó também, mas digamos que ele consiga, eu tenho uma enorme dificuldade de imaginar que 
isso substitui o conteúdo, isso é minha, porque eu acho que tem pessoas que acham que você a partir daqui, a partir do trabalho por projetos e que eles chamam de inclusive, já vem essa confusão, já vem até do, isso não é novo, se você pegar toda a, quer dizer a proposta de Paulo Freire, em termos de temática, ela no fundo é trabalho por projetos, ela elege um tema, e esse tema é um tema motivador, e esse tema motivador em cima do qual você organiza a construção do conhecimento, e ali já aparece aahhh esse problema do conteúdo de uma certa forma já está presente é principalmente quando você vem para o ensino médio, porque enquanto você está no ensino fundamental, essa, essa proposta temática ela é muito mais, ela faz muito mais sentido para mim pessoalmente, ela faz muito mais sentido porque é você, a sistematização do conhecimento, toda vez que você está construindo, um pensar sobre o que é ciência, um pensar sobre questões mais amplas é, a diversidade de assuntos que você vai trabalhar não complica e nem compromete a construção de um conhecimento muito bem definido, mas o ensino médio, ele tem uma outra característica, então ele entra muito em conflito com essa idéia de projeto, agora num projeto que ta colocado aqui, quer dizer como você está colocando, esse é um projeto motivador, é um projeto importante, é um projeto etc. $\mathrm{Eu}$, eu tenho duvidas que, eu tenho certeza que aqui dentro tem conteúdos, mas eu tenho duvidas que os conteúdos que estão aqui, eles dão conta é do conhecimento. E porque que eu acho que não dão conta? Porque ahhh tem dois aspectos que são, primeiro eles tem uma visão incompleta, quer dizer você só vai abordar coisas parciais.

\section{V- É um recorte? \\ $\mathrm{P}_{6}$ - é um recorte.}

V- Você esta fazendo um recorte para esta situação.

$\mathrm{P}_{6^{-}} \mathrm{O}$ recorte para essa situação você até pode, mas acontece que e aqui entra o segundo problema é, pelo menos isso na física isso é muito importante e acredito que na química também é, o conhecimento é muito articulado, quer dizer, se eu pego um pedaço, ele não tem, o sentido do pedaço é dado por um todo maior e esse todo ele implica em eu sistematizando para os alunos, sei lá, é eu vejo mesmo que eu estude lá o movimento, o movimento em sentido, porque eu quero estudar a relação de força com o movimento porque eu tenho por trás da idéia de ver princípios da natureza de conservação, de como é que acontece a conservação de energia etc. acontece. Essas coisas estão articuladas, se eu der uma sem a outra sem a outra, não cria para o aluno o instrumento de apreciação da realidade futura, ora pra você aprofundar esses conceitos, você tem que demorar, você tem que parar e aprofundar, quando você faz a profundidade disso o seu projeto que está querendo ver outra coisa vai lá longe e você não chegou nele, então agente tem, eu tenho trabalhado com isso e enfrento esse mesmo problema, porque nós trabalhamos agora, minha preocupação é mais com o meio ambiente, então energia, água, com temas assim, então você tem exatamente.

\section{V- Quer dizer vai para os temas que caem mais ou menos.}

$\mathrm{P}_{6^{-}}$Que caem nesse aspecto, que são, como é que você vai trabalhar a questão do ambiente, quando você tem ao mesmo tempo, que se aprofundar em certos conceitos, mas 
ao mesmo tempo tem que dar um olhar geral, então do que eu acho que isso é um nó e que trabalho por projetos não substitui o trabalho em sala de aula de conteúdo não substitui, tem que estar articulado, também, não pode ser coisas completamente diferentes.

V- Eu pensei articulado, mas não com essa profundidade que você esta falando em relação entre os próprios conteúdos, eu pensei assim, quando estava trabalhando) tudo bem tem mil maneiras. Não, não, não eu sei, mas é esse sentido é mais amplo do que você está falando, esse conteúdo com esse, com esse,com esse e com esse para que a pessoa ter um entendimento assim, na época nós pensávamos assim foi isso que eu fiz, incentivar os professores a fazer realmente o recorte do conteúdo, o momento de se parar para descer aos conteúdos isso dar aquilo do ponto de vista, assim do conhecimento sistematicamente elaborado, mas mesmo assim é um recorte).

$\mathrm{P}_{6}$ - É um recorte, e ai quer dizer, você tem que ter um cuidado de sistematização, porque se não você vê fragmentos, fragmentos de coisas e você, nesse projeto você vê um fragmento de alguma coisa, no outro, mas de novo esse fragmento não fala com aquele fragmento, o que eu fiz nesse projeto não tem nada a ver com aquele, então você de novo você está fragmentando, não esta construindo. O nó da unicidade que não existe no conhecimento, quer dizer é hoje resolvido um pouco por essas teorias como complexidade, quer dizer você só trabalha com recortes, seu recorte é um recorte, nunca é único e você tem que confiar que aquele seu recorte, a medida que você faz vários recortes da realidade vai se construindo um quadro da realidade como construção de conhecimento, como epistemologia da complexidade lá do Morin e etc. que tentam dar conta disso, que não é um problema educacional nosso só pequeno, ele é a construção do conhecimento que está alem das disciplinas e hoje você tem, e principalmente no século nosso. produzindo.

$\mathrm{V}$ - Na atual conjuntura, que você tem tanto conhecimento que está sendo

$\mathrm{P}_{6}$ - É exatamente, é uma característica do nosso tempo, não tenha duvida nenhuma, e é essa complexidade que está ai que tem, que a complexidade nunca se reduz a uma sequiência de ações simples, quer dizer, a complexidade, portanto é característica da complexidade eu acho, que o olhar da complexidade, é um olhar que te é que nos da uma certa segurança, embora, por outro lado, eu acho que o olhar da complexidade é um olhar muito pouco político, educacional, porque é um olhar muito de vários, ele tira muito valor, quando você lê essas teorias da complexidade etc., mas por outro lado, ele da essa sensação de que não existe o todo, existem recortes que cada um vai ter que ir fazendo, quer dizer, em cada situação, em cada momento você faz recortes de um todo, não existe esse todo, é um pouco contra aquela visão holística de que existe um todo e nós vamos nos apropriar desse todo, não existe esse todo, nós vamos ter que.

V- Quer dizer que é o que Dellors falou é o aprender a aprender, é aquilo?.

$\mathrm{P}_{6^{-}}$É um pouco nessa direção, exatamente, o holístico como o Morrin eles são holográficos, eu pego uma coisa e vejo desse olhar, depois aquela imagem, eu vejo outras mais, quando eu olho por aqui eu vejo outra imagem, quer dizer não existe a imagem, 
existe olhares diferentes sobre a imagem que eu vou juntar e que esse é o processo como agente, então esse processo.

V- Isso é sustentado pela física? Essa fala dele da complexidade da holografia? É de olhar, por exemplo, de um ponto de olhar de outro, no discurso é muito interessante, mas do ponta de vista acadêmico isso tem consistência?

$\mathrm{P}_{6}$ - Ah, eu não sei depende, depende do que você, eu acho que existe sim, quer dizer existe uma situação, depende, depende das circunstancias, da situação, do limite em que você está fazendo, eu acho que existe, de fato, qualquer problema que você tem você pode olhar de varias maneiras, se eu pegar um problema e olhar em níveis diferentes, se eu olhar no nível macroscópico o problema, se eu olhar no nível em nanotecnologia ou em nano, em nível molecular eu vou ver fenômenos diferentes que estão acontecendo, mas o que é o todo daquilo? Eu não sei, todo é o objeto que eu posso olhar de maneiras diferentes, recortes diferentes e das informações diferentes sobre o objeto. Nesse sentido, eu acho que a complexidade vale também pra física, para os olhares da física, talvez não valha no sentido da imagem da analogia que ele fez com a holografia porque ele é muito limitado, ele usou, eu acho que eu nem sei quando que foi esse texto ai, teve uma analogia com a holografia, mas era muito limitado, agora também por outro lado, ele é muito sensorial, porque de fato quando você tem uma holografia você olha, e você vê coisas diferentes, formas de ver, e você nunca sabe o que está lá, porque você nunca consegue, você não tem a imagem concreta, você nunca pode pegar a imagem, aquela imagem não existe a não ser através desses olhares, então nesse aspecto tem uma analogia, e como a analogia que eu estou usando, não sei, agora acho que tem aqui um programa de construção do conhecimento e de epistemologia do nosso tempo, da relação de conhecimento, dos limites do conhecimento, das formas de conhecer que temos hoje e isso tem sido ai pelas filosofias da vida discutido e estudado, agora como é que isso, claro se reflete na educação, lógico, lógico que nós estamos construindo conhecimento, e digo até de maneiras diferentes, não é aquela epistemológica lá, mas é uma discussão mais é que se da nas praticas que agente ta tentando, e é esse discurso que você está falando, que é complicadíssimo, como é que eu olho isso e olho o conteúdo especifico, então hoje eu não abro mão de uma certa sistematização, eu acho que agente vai na física, pelo menos, eu consigo hoje, por exemplo, ir nós estamos, digamos que nós estamos abrindo mão, estamos tentando ver em cada caso, nessas experiências o que agente está tentando vivenciar, é quanto você pode abrir mão é de certas, certos cânones, de certas práticas, seqüências e conteúdos etc, que viraram tradição e quanto você pode ir chegando a esse tema, então é essa, aproximação mútua que você tem que fazer.

\section{V- Esse esforço que você está tentando fazer agora?}

$\mathrm{P}_{6^{-}}$Que eu acho que agente devia tentar fazer pra ver o que agente pra ver o que é essencial, no fundo, no fundo, o que são os conceitos, o que são as coisas essenciais do conhecimento físico, e como é que eu posso trabalhar de formas diferentes mais em termos de projetos mais, também em termos de projeto, mais que depois eu consiga amarrar, sistematizar e construir uma coisa comum.

V- E isso, está sendo pensando na sua disciplina fazendo isso, na sua disciplina ou 
isso já tem envolvimento de outros?

$\mathrm{P}_{6}$ - Não, não, não na minha disciplina aqui não, minha disciplina que eu dou aqui na universidade é outra coisa, eu estou pensando no trabalho que nós fazemos com os professores de ensino médio É na formação de professores. Aqui eu acho que tem uma outra característica. Então por exemplo, eu vou te dar um exemplo pra você imaginar, quer dizer pra você ver, eu acho que é super difícil, mais é, então tem hoje um dos alunos que estão trabalhando comigo, ele está trabalhando, ele queria trabalhar em meteorologia e tal, mas no fundo, agente melhorou um pouco a questão é para ficar um clima, e de clima, estudar o clima que dia é hoje , como é que faz, que historia é essa, então agente foi, seja um problema que é a previsão de tempo, porque é um problema que as pessoas sempre se questionam da certo ou não da certo, da pra prever não da pra prever, é um pouco problematizador, mas o problematizador que tem por trás disso, quer dizer, o tema que tem por trás disso é que a escola não ajuda muito, quer dizer, deveria também incorporar na sua forma de olhar o mundo a questão do clima, se chove se não chove, essas relações entre os parâmetros, quer dizer, etc. quer dizer tentar olhar isso ai, então como é que ele foi buscar na física eu vou buscar isso dentro da chamada termodinâmica. Ou pelo menos, um pedaço da termodinâmica, que se ensina no ensino médio que trabalha com isso no nível em que o ensino médio trabalha, qual é o esforço? Bem, eu vou juntar aqui quais são os conceitos fundamentais que esta termodinâmica tem que trabalhar, ai eu tenho que trabalhar, por exemplo, diferença entre calor e temperatura, isso é fundamental, eu tenho que trabalhar o equilíbrio térmico, tudo bem, mas eu preciso trabalhar a relação calor temperatura que aparece lá numa expressão $\mathrm{Q}=\mathrm{mcxt}$, eu preciso trabalhar para dizer que eu vou matematizar, porque se eu fizer só uma lista de temas você não, eu preciso ver os processos de troca de calor, porque aqui, e aqui eu vou fazer um elenco de coisas. E aqui eu vou fazer as coisas que os alunos podem trabalhar dentro da previsão do tempo, a o que tem pra ver, temperatura do dia, máxima mínima, termômetro, não sei o que

\section{V- Quer dizer as atividades que eles poderiam fazer}

$\mathrm{P}_{6}$ - Aqui tem um rol de coisas, e eu tenho que articular, e esse é o trabalho difícil, de articular, esse problema que é um projetinho que desenvolve ao longo de algumas semanas para descobrir que a previsão do tempo funciona ou não funciona, ao mesmo tempo eu tenho que inserir, de alguma forma, que cá entre nós que pra mim é fundamental que seja organizada (risos)

V- Não, não, não, até pré explicar isso aqui, porque se não...

$\mathrm{P}_{6}$ - Bom, eu posso fazer em grupos disso com grupos de fenômenos, então para um certo grupo de fenômenos eu elejo, e ai eu faço uma seleção mesmo, aqui tem muitas outras coisas que eu não vou trabalhar, mas eu só vou trabalhar calor, temperatura e não sei o que, aqui nesse grupo água, umidade, entendeu eu vou trabalhar só mudança de estado ou não sei o que pararaaaaá, porque vai ter pluviômetro etc. tararaaaá, fluxo, vazão e etc. Aqui nesse grupo daqui eu vou trabalhar, qual o âmbito da termodinâmica que eu consigo dar conta? A aqui é vento, aqui é pressão atmosférica e tal, como é que eu sistematizo esses conceitos de forma que no final eu tenha um conjunto de conceitos que sejam, que tenham vida própria, que sejam construídos, que eu possa usar em outros exemplos e não só nesses 
exemplos e que tenham sido criados ao longo desse trabalho aqui, esse trabalho está sendo um pouco como motivador para eu trabalhar calor temperatura, só que na hora que eu pego essa relação porque aqui ela é importante, que ela aparece, o sol aquece diferentemente os objetos, eu tenho que levar ela para outros contextos, mostrar olha, funciona aqui mas funciona em muitas outras situações. O que agente vê nisso tudo, é um processo que até possível só que ele é longo. E ai o que acontece, então.

\section{V- O outro nó né?}

$\mathrm{P}_{6^{-}} \mathrm{O}$ outro nó é que construir conhecimento é um processo demorado e ai o que eu acho que é a solução é você abrir mão de ser complexo é, é um problema. È abrir mão de ser e construir melhor e menos coisas. Então o que está fazendo agora se eu pegar essa experiência que já fizemos uma vez, agora já estamos nessa segunda vez ai de estar fazendo isso, não já fiz isso em outro contexto, agora qual é a minha proposta, será que se eu trabalhar um conjunto, um tema, com alguns os alunos eu aprofundaria isso, com outros eu vou aprofundar outra coisa, todos vão ter ouvido falar de temperatura, de pressão, de vento, disso e daquilo de clima, mas aprofundar o conceito não dá no espaço que ele tem de $\mathrm{x}$ aulas, se eu tivesse mais eu poderia mas naquele $\mathrm{x}$ de aula eu tenho que fazer seleção de conteúdos, não há como você não fazer seleção de conteúdos, ai entra um outro aspecto, que eu acho que agente também tem que repensar no ensino médio nesse aspecto, que é assim, é, depois como é que fica é o fato de que eu tenho que abrir mão de conteúdos mesmo, eu tenho que abrir mão de conteúdos de uma maneira geral para trabalhar menos coisas. Agora, eu sinto que quando você faz essa abordagem, Valdir, você introduz as palavras, você introduz um vocabulário, agente cria com os alunos um vocabulário, então eles passam a saber que existe algumas coisas, embora ele não saiba exatamente o que é ele sabe até como mede, ele sabe até para que serve, mas ele não vai aprofundar completamente isso, eu acho que se você, estou desconfiada que se você aprofundar um conceito e pra mim parece que não há uma seqüência nisso, tanto faz, o jeito que você trabalha etc, etc, etc, já abre um pouco o caminho para que ele numa situação, que ele precise, sabe Deus quando e como, ele possa fazer isso com os outros que você não fez, ele tem contato com uma informação que é muito maior do que aquilo que ele pode construir como conhecimento construído. Daquela informação como enorme, você seleciona algum conhecimento que de fato ele pode aprofundar e construir o resto ele ouve falar, mas de alguns aspectos, ele aprofunda, esse que ele aprofunda tem que ser sistematizado, tem que ta realmente construído e tem que ter um alcance pra fora do caso particular que ele está vendo, entender que aquilo é um instrumento para compreender outras coisas que não só aquilo que ele está vendo, que são relações fundamentais que agente tem que trabalhar. Agora, eu acho que isso é um grande nó, e é um nó que não é num modo interdisciplinaridade, não é, é um nó do que é possível fazer na escolaridade básica.

V- E principalmente no Brasil, o nó se torna maior culturalmente vira as coisas para pré requisito do vestibular. Com certeza.

V- Ai você tem as criticas mais, e ai eu acho que não tem o menor problema, eu acho que a escolaridade básica não é para preparar para a universidade (V: Eu também tenho essa convicção). 
$\mathrm{P}_{6^{-}}$E a minha proposta, e que nunca e que foi pichada por todos os lados.

V- Isso é interessante, talvez a possibilidade, talvez, descendo um dos conteúdos que eu eleja, ele consiga depois numa outra situação ter facilidade pra ele pesquisar e ele chegar a conclusões, eu também não sei o que é bem mas ele faz lá, então por exemplo, você perguntou. Isso justifica o aprender a aprender? É como se você desce algumas ferramentas?

$\mathrm{P}_{6^{-}}$Dar algumas ferramentas de pensar de construir, fazer gráficos e tudo mais. Agora aqui tem enormes problemas, então o que eu sinto é assim, aqui tem uma necessidade, nós acadêmicos de achar que o aluno só aprende quando ele aprende tudo arrumadinho, mas eu acho que ele aprende, aprende de maneiras muito diferenciadas, então eu tenho uma experiência, aqui agora na universidade, agente aqui não tem uma disciplina que você dá, você dá uma porção de disciplinas, você não tem como dar só uma disciplina. Então uma disciplina que eu trabalho com ela a muito tempo, que é física do meio ambiente, a física do meio ambiente tem esse problema, como é que eu vou construir um conhecimento aqui, se ele é temático, e dentro da física ele trata dentro da física o problema que você tem entre disciplinas, você entre áreas da física, entre coisas da física, fora a interdisciplinaridade.

\section{V- E está "rolando" o tempo todo.}

$\mathrm{P}_{6}$ - E está rolando o tempo todo, esse é o grande problema, então você veja que o problema, por exemplo, eu preciso trabalhar de saída, conceitos de física moderna, porque eu preciso trabalhar na interação da radiação ? No fundo eu preciso dizer para o aluno o que acontece, o que é uma radiação infravermelha faz, porque que ela aquece, porque uma radiação no microonda, porque uma radiação, o que é um ultravioleta, o que acontece quando ele interage com o ar, se passa ou se não passa, quer dizer, eu preciso de cada para avaliar uma serie de fenômenos desses, e que são de trabalho da física moderna, e que se eu fosse trabalhar na forma como a física exige eu precisaria de muitos conceitos muito bem digeridos.

\section{V- Deixaria aquela coisa cartesiana de pedaço por pedaço, pronto.}

$\mathrm{P}_{6}$ - Então o que agente faz, que isso eu aprendi fazer na biologia quando eu dava aula, você desenvolve uma maneira de apresentar que é um pouco operacional, quer dizer, olha funciona assim, não dá para descer aos porquês de quanto aquilo funciona, funciona assim, então é um conhecimento em que o nível de conhecimento, em que eu não estou fundamentando esse operacional, mas, eu estou dessa maneira, dizendo pra que serve, por exemplo, existe uma relação entre a temperatura de um corpo e a radiação que ele emite, eu não vou explicar como, algum dia ele vai explicar na física, porque, e que radiação é essa, só que eu digo para ele oh, sabe o que é, tem uma formulinha, que relaciona assim, ta, é uma constante que funciona assim, quando esse aumenta esse diminui e olha, e bom, então o que eu faço, a eu uso isso aqui para que, pra ver a temperatura do sol, para ver a radiação que eu emito, pra radiação que um corpo qualquer emite, porque todo mundo tem temperatura, pararaaraaá, ta então eu trabalho com um nível operacional dessa coisa. Nesse sentido, ele é desarticulado esses conhecimentos, porque é justamente aquela coisa 
que eu estou constando, eu já não estou vendo porque que isso tem a ver com outro aspecto lá mais quântico, nem com isso aqui, que compõem o corpo da física moderna de forma articulada. Nesse momento do aprendizado eu acho que eu dou conta disso, porque eu tenho uma garantia que mais tarde vai ter uma disciplina lá na formação deles em um outro momento da formação dele em que ele vai ver essas coisas de novo, vai voltar a ver de novo e aí ele vai ter a oportunidade de articular, e melhor porque quando ele começar a ver de novo, é de novo, quer dizer, para muitos vai ser a primeira vez, mas para aqueles que é de novo eles já viram como serve, como funciona.

\section{V- Entendi a aplicabilidade daquilo.}

$\mathrm{P}_{6^{-}} \mathrm{O}$ operacional da coisa, então você trazendo para cá eu acho que a gente tem que se conformar no ensino médio que algumas coisas que nós vamos trabalhar só no nível operacional e com outros conhecimentos que a gente vai de certa forma fundamentar melhor, quer dizer se a gente conseguir um nível médio separar o que é que, aquela coisa que nós temos todos de vício, não sei quanto você tem deste vício de querer que o aluno aprenda até o fundo de que ele tenha um conhecimento fundamentado e tal, por que? Porque a gente acha que esse conhecimento fundamentado é aquele que está mais bem construído que vai dar mais ferramenta para ele, talvez não, talvez a gente tenha que restringir a trabalhar num nível muito mais operacional e na formação dele entende a formação dele como um todo, não é o professor de física, de química, não sei o que, em alguns momentos ele vai ter uma fundamentação maior e em outros ele vai trabalhar fundamentos operacionais mesmo. Como eu digo no meu curso que alguns momentos eu faço isso, porque eu garanto outros lá na frente, é isso se dá em ao longo de uma construção de três anos no ensino de física, não é que aquele momento do seu curso vai estar, tem que dar conta de tudo, e não só da física, da química, da biologia, quer dizer cada um vai ter que selecionar aquilo em que realmente vai aprofundar e aquilo que ele vai ver só no nível operacional, e aí eu acho que é o critério que você vai poder trabalhar a extensão dos conteúdos em relação ao conhecimento. Você não vai poder trabalhar tudo, em algumas coisas você vai trabalhar mais no nível operacional, mas olha faz assim é assim que faz serve para isso e outro eu vou aprofundar.

$\mathrm{P}_{6^{-}} \mathrm{O}$ terceiro problema, o problema do vestibular, bom o problema do vestibular é o seguinte, ensino médio não para preparar para a universidade (V- está lá os parâmetros dizem isso) o ensino médio só tem como, só pode ter como final de avaliação algo que não é seletivo, porque aqui não tem a preocupação em não seletivo que tipo o ENEM, não precisa ser o ENEM que está aí, mas teria que ser o exame dessa natureza, que vai buscar competência mais do que conteúdos, porque a escola brasileira é totalmente diferente etc. Se a gente batalhar dos dois lados em que esse não é para universidade, nós temos que garantir o que faz o aluno ir para essa universidade, porque eu acho que isso é o nó, isso aqui tem várias possibilidades, vários caminhos, eu acho que nós temos que defender, da mesma maneira que eu defendo que a universidade não vai exigir pra entrar nela o fim da escolaridade, não é isso, isso aqui tem um gap, porque eu acho que não são todos os alunos da escola pública, nem da escola particular, nem de qualquer escola que precisam vir para a academia, para a universidade, ele tem uma porção de possibilidades de trabalho, de formação, outras muito melhores, a universidade não é nada disso que eles imaginam e eu acho que eles a gente tem que brigar para que isso seja muito claro. Agora, se obriga pra ser 
isso muito claro, se eu tiver formas de acesso, então eu vou te falar a minha idéia louca que já foi pichada, eu apanhei por todos os lados, quando eu coloquei isso, (V - eu gostaria muito de saber) na Secretaria da Educação, então foi uma festa, eu apanhei dos meus amigos, apanhei do pessoal da universidade e da física, do pessoal da graduação, porque é assim eu acho que a escolaridade básica são três anos etc. As secretarias de educação devia ser função do estado, prover os meios dos alunos entrarem na universidade. Então o estado deveria ter um quarto, que não é obrigatório, que é gratuito, que não tem nenhum diploma e que ele é simplesmente um cursinho entre aspas com formador para quem quer ir para a universidade, bom "caíram de pau", por todos os motivos que eu entendo que isso é uma crítica complicada e nós vamos olhar. Agora, isso aqui não seria para cada escola, porque você não está, não são os todos os alunos de escola pública que querem entrar na universidade, aqueles que quiserem, e é fundamental que seja voluntário, o estado tem que dispor de uma estrutura que permita a eles acessar o conhecimento formalizado etc, de uma maneira mais completa e de uma forma um pouco diferente do que ele viu, para fazer essa ponte para a universidade. Eu não estou defendendo que essa escola daqui não tem como objetivo a universidade, eu tenho que prover e a universidade continua dizendo mais que quero um aluno que não é só isso, que tenha mais do que isso, alguém tem que fazer esse papel.

\section{V - Estreitar isso daí.}

$\mathrm{P}_{6}-$ Se existe um cursinho particular, tudo bem, tem que existir uma instituição no estado que faça esse papel. Nós temos experiências fantásticas, porque quando o aluno faz, nós temos experiências desse tipo que não são cursinhos, mas que são feitas em escolas da rede publica, e que são pessoas voluntárias que vão lá e organizam os alunos com grupos de estudo pra entrar na universidade, e eu tenho aqui vários alunos que vieram de grupos de estudos de universidades públicas desenvolvidos por professores que por sua vez já tinham entrado aqui, porque a gente tem um tempo, que já se reproduziu, inclusive tem uns na pós do ensino agora dois, ou três que vieram desse processo, então qual é, o que tem de vantagem, o que é que funciona aqui, funciona porque é assim, só um aluno que quer.

\section{V- Ele já definiu?}

$\mathrm{P}_{6}$ - Ele quer, ele vai ficar sozinho, ele não está paparicado para estudar se ele quer e ele vai estudar sozinho, você tem que dar os meios pra ele fazer isso, ele não tem obrigatoriedade, ele só vai se ele quer, então você acaba com todos os enormes problemas da escola, você reduz o numero de alunos que tenham vocação, porque eu acho que é vocação, para um trabalho diferenciado e de educação posterior, enfim com esse.

V- Só assim $\mathrm{P}_{6}$, quando se pensa pela idéia que eu tive da nossa conversa, você pensa na interdisciplinaridade nesses momentos que nós discutimos todos, dessa possibilidade, mas é entre professores e não na perspectiva a partir do professor, um professor tendo uma visão interdisciplinar, ou seja, o professor fazer a interdisciplinaridade, pra isso ele vai ter que dominar o conceito da física, o conceito da química, o conceito da biologia, pra ele se apropriar disso, você acha isso possível? 
$\mathrm{P}_{6^{-}} \mathrm{Eu}$ acho que isso é meio difícil, porque assim. Também é necessário nesses momentos, ou é uma outra vertente? Naquele momento que nós estávamos falando em que eu vou buscar a interdisciplinaridade, quando eu falo que na física eu trabalho com velocidade assim, eu tenho que fazer um esforço de entender, eu docente de física onde estão os exemplos nas outras áreas para eu poder sinalizar para o meu aluno, então nesse momento é o professor de física que está buscando extrapolar o seu objeto imediato e buscar links ou conhecimento das outras áreas, então esse é o movimento meu de professor, claro que eu não tenho tempo, eu não tenho oportunidade, não tenho um porção de coisas, mas alguém que possa fazer isso tem que sinalizar para mim, se eu sou um professor que não tenha tudo isso, mas alguém tem que começar a buscar essas pontes do conhecimento que possa feito, por exemplo, é eu vou te falar que, por exemplo, eu dava aula, que não é ensino médio, que não vale, mas que dá um pouco de luz; eu dava aula de física para biólogos, então eu tive que aprender muita biologia para dar aula de física pra biólogos, porque se eu vou ensinar pra eles da física de um sistema que é, que tem uma lógica, dentro da biologia, eu preciso saber como é que funciona esse sistema, a fisiologia dos animais, para trabalhar as relações de pressão, osmose não sei o que, eu preciso descobrir a fisiologia dos animais, como é que é a respiração, eu tenho que estudar muito a biologia para poder fazer essa ponte, e eles gostam muito, porque ai eles conseguem ver o olhar da física sobre o objeto de estudo que eles tem dentro da própria biologia, com outros olhares, então são olhares que se complementam no mesmo objeto. Quando agente fez a estrutura curricular, inclusive eu dizia, tem que ter o mesmo tema trabalhado na física, o mesmo tema trabalhado em alguma disciplina da biologia, ah, mas como? Duplicidade não, a duplicidade que é importante, porque ele vai ver um olhar diferente sobre os mesmos objetos, o mesmo jeito, o mesmo problema, ele vai ver de formas e trabalhar diferente, então eu acho que tem um pedaço ai que caberia a cada professor, não é cada professor individualmente, mas a cada disciplina buscar com as outras disciplinas um pouco os seus caminhos, quer dizer, os seus, onde é que estão as coisas que eu posso trabalhar aqui e serve pra lá, agora isso dificilmente o professor na escola consegue fazer, porque ele está assoberbado com as suas coisas, eu acho que isso cabe a nós que estamos trabalhando com ensino, ir buscando essas pontes ai, esses jeitos de trazer pra dentro de cada um, os seus, os seus saberes, isso não é o professor que vai fazer, mas eu acho que tem um espaço interdisciplinar que é construído dentro da própria disciplina, que é esse, não sei se ele se chama interdisciplinar, mas esse olhar pros outros que é necessário, eu acho que isso daí, olha é muito gratificante quando você consegue, porque você mesmo como professor, você consegue entender uma coisa, que você, quando eu entender a química eu vou ficar felicíssima, porque hoje eu não entendo química (risos). Uma porção de coisas lá, de energia, eu falei nossa esses químicos, como é que eles analisam, se eu conseguir entender e traduzir, e isso que é legal traduzir aquele conhecimento, o conhecimento da física eu dou um salto muito grande num conhecimento que eu possa trabalhar com meus alunos.

$\mathrm{V}$ - O que significa muito mais, o que você fez com a biologia levando os conceitos de física para o campo deles.

$\mathrm{P}_{6^{-}}$Exatamente, mas isso significa que eu preciso estudar, então isso não é uma coisa que eu acho que dá pra fazer, da pra fazer numa escola ideal, mas não na escola real do ensino médio. Isso cabe aos formadores, cabe aos formadores e aos formadores e formadores, a gente tentar ir construindo esses caminhos, agora, por exemplo, com esta 
perspectiva, porque eu trabalho com física do meio ambiente, agente já construiu, e nós vamos precisar da ajuda dos químicos, é sempre um rolo, nós já fizemos trabalhos, por exemplo, energia a água e algumas outras coisas também, mas principalmente de energia e água, você pega assim, energia, todas as series, de todos os anos, tudo que tem energia onde que é visto na química, na biologia não sei o que, fazer uns certos mapas, depois a água, a água é uma coisa interessante, como é que a água aparece na disciplina de geografia, quer dizer, eu falei isso daqui, mas tem a disciplina de geografia aqui, porque na física do meio ambiente eu preciso trabalhar com geografia também, e talvez até com as formas, mas no começo com a geografia, então, como é que se começa a ver, a construir os quadros, pelo menos, que você veja como que o conteúdo aparece nele, não dá ainda para fazer uma proposta de como é que eu vou juntar isso com aquilo, porque eu acho que inclusive que não há uma proposta só, vão ser muitas, mas de começar a ter uns quadros de ver onde que são as possibilidades que eu tenho que trabalhar dentro desse aquelas coisas que eles vão ver de outro jeito lá, e ai tem umas sinalizações, professor? Como é que o professor de biologia dá isso desse jeito, veja quando agente vai trabalhar nisso pra ele se lembrar que o aluno viu aquilo, quer dizer, é fazer uns contrapontos assim, mas isso requer, um trabalho que não é de um professor só, é um trabalho coletivo, quer dizer, eu acho que tem que ser feito das universidades, formadores de formadores, nas secretarias de educação, nos centros em que se pensam a estruturação do conhecimento e não num professor de sala de aula.

$\mathrm{V}-\mathrm{P}_{6}$, muito obrigado pela disponibilidade e disposição. 
Entrevista: $\mathrm{P}_{7}$

Data: 25/06/2006

Tempo Total: $33 \mathrm{~min}$.

$\mathrm{V}^{40}$ - Bom, o nosso trabalho está relacionado a currículos integrados, e isso faz ler alguns autores, por exemplo, na década de setenta, e oitenta lendo, pesquisamos os trabalhos de Japiassu, Ivanir Fazenda, indo um pouquinho no filósofo humanista, Georges Gusdorf.

$\mathrm{P}_{7}^{41}$ - Onde se verifica a origem do pensamento do Japiassu.

V- Isso mesmo, o que me parece que naquela momento, o que eles pretendiam era uma interdisplinaridade no sentido de uma fusão das disciplinas.

$\mathrm{P}_{7}$ - Menos fusão, mas inter-relação.

V- Naquela época, eles pensavam assim?

$\mathrm{P}_{7}-$ [Com um sentido de inter-relação,] (1) [porque a idéia de fusão das disciplinas é um principio que está ligado com a idéia de transdisciplinaridade.] (2)

\section{V- OK}

$\mathrm{P}_{7^{-}}$Mas na verdade o Gusdorf, o pensamento do Gusdorf está mais muito relacionado com uma crítica com a estrutura da universidade. Ele faz um contexto de críticas de organização do conhecimento na universidade e faz isso num nível muito epistemológico, e é isso que o Japiassu aproveita, mas o Japiassu acaba fazendo, na minha opinião, no ponto de vista de uma forma que se forma uma patologia do saber, quase que uma doença mesmo, uma degeneração, a disciplinarização como sendo uma degeneração do saber.

V- Creio que ele polariza em excesso.

$\mathrm{P}_{7}$ - Isso, e aí você tem problemas nisso, porque a disciplinarização não é o problema dela ser degeneração, porque [a disciplinarização é uma construção social, é um processo que levou a construção do conhecimento no pensamento moderno e é estruturado dessa maneira] (3) e a interdisciplinaridade não pode ser uma visão salvacionista, porque de certa forma em alguns momentos, particularmente nos trabalhos de Japiassu da época, localizado, ao que parece trazia muito essa visão salvacionista.

V- E aí ao que parece, quer queira quer não, a disciplinaridade sempre existiu historicamente, é isso?

\footnotetext{
${ }^{40}$ Refere-se ao entrevistador: Valdir Pedro Berti

${ }^{41}$ Refere-se a $\mathrm{P}_{7}$.
} 
$\mathrm{P}_{7-}$ Sim, na verdade ele não está fazendo ali, que ao meu ver, não é um problema da transposição da discussão do Japiassu para a escola, porque ali ele está discutindo no campo da universidade, um conhecimento acadêmico, ele não tem nem formação educacional, nem formação de currículo, ele não está dialogando com o que seria pensar um currículo interdisciplinar na escola, não um problema para ele, não uma questão que está em pauta para ele.

\section{V- Como efetivar isso na prática?}

$\mathrm{P}_{7^{-}}$Não, não, é como se efetivar isso na prática, porque ele está pensando isso na prática, na prática da universidade, são outros problemas, são outras questões, a forma de organização do conhecimento é outra, as relações sociais na instituição são outras.

V- Agora, indo para autores como Machado e Ulisses, eu já percebo uma dermacação.

\section{$\mathrm{P}_{7-}$ Quem? É o Nilson Machado de quem você está falando?}

V-Sim, ou seja, isso já está superado, você tem especificidades (as disciplinas) e elas são convidadas a dialogar sobre uma problema maior? Mas a questão é, isso pode ser feito? No caso, por exemplo, você tem todo um trabalho voltado para currículo; então eu pergunto, é possível fazer uma integração do currículo, mantendo a especificidade da química, os saberes epistemológicos da química tem, física, biologia, isso é possível?

$\mathrm{P}_{7^{-}}$Eu diria que é possível, mas eu diria que com isso você permanece no currículo disciplinar, e aí que entra na discussão que eu faço naquele livro "Disciplinas e Integração curricular: histórias e políticas" em que tem um texto meu com a "Beth", que trata da estabilidade do currículo disciplinar, em que a gente argumenta, justamente, como é que [o currículo disciplinar convive com o currículo integrado], (4) ao longo da história da escola. Se a gente pegar as diferentes organizações curriculares, ao longo da história, gente consegue observar que tem uma série de atividades de propostas, na prática que são de currículos integrados, eu não gosto de falar de interdisciplinaridade, porque [a interdisciplinaridade é uma das formas do currículo integrado.] (5) O currículo integrado é mais amplo se você pensar na idéia de pensar nos Temas Geradores, nos Temas Transversais, pensar nos Projetos; então tem várias propostas neste sentido, mas [o currículo disciplinar prevalece.] (6) Por quê? Porque o currículo não é simplesmente o fato de você ter química, física e biologia, história e geografia, o currículo disciplinar é uma forma de organização do controle do trabalho dos professores e dos alunos; então, eu posso, por exemplo, chegar e dizer, não eu vou fazer uma interação das disciplinas, como disse o Nilson Machado. Então eu vou inter-relacionar física com química, química com biologia, geografia com história, português com educação física, ou então química com português e de repente eu vou fazer tais inter-relações que geram projetos. Ah, então o projeto A, B e C, a questão é como é que eu organizo isso. Das 08:00 as 8:50 é a hora do projeto A, das 09:00 em diante é hora do projeto $\mathrm{B}$ etc. Isso é uma disciplinarização do ponto de vista da organização curricular, ela não é uma disciplinarização do ponto de vista epistemológico do saber acadêmico de referência., ou seja, não é a química. Então você tem que estar discutindo qual a concepção de disciplinas em que as pessoas estão trabalhando. 


\section{$\mathrm{V}$ - Talvez seja isso.}

$\mathrm{P}_{7^{-}}$Se você pensa na disciplina como uma referência ao saber acadêmico universitário epistemológico, então qual é a disciplina, você tem química, física, biologia, isso na universidade, que existe na universidade. Aí tem um outro tipo de relação, você está fazendo uma relação epistemológica. Eu não trabalho com a concepção de disciplina do ponto de vista epistemológico, eu trabalho com [uma concepção de disciplina sóciohistórica de organização curricular que é a que leva a fragmentação do conhecimento], (7) né? Você segmenta as pessoas nos encontros, os horários na matriz curricular, estabelecer que tem grade, que primeiro vem isso, depois aquilo, o que vem antes não conversa com que vem depois, então não importa se é química, física história e geografia, por ser orientação sexual e educação para cidadania, você está numa matriz disciplinar, então como o currículo não é uma questão da nossa vontade, ele [depende das relações sociais, a disciplinarização permanece], (8) ela permanece como essa matriz que organiza o trabalho dos professores e dos alunos e que de uma forma geral, além de ser uma matriz que organiza os trabalhos dos professores e dos alunos, também é uma referência do saber acadêmico; então ale de ser essa disciplina que marca o horariozinho (das 07:00 as 07:50; das 08:00 as 08:50 etc.) bonitinho, o professor A na sala B, tudo direitinho, que marca o horário, a grade, além de ser tudo isso, essas disciplinas tendem a ser disciplinas relacionadas ao saber acadêmico, ou seja, química, física, história e geografia, cidadania, ética, meio ambiente, temáticas (você poderia ter na escola poluição) e aí você iria estudar química, física, biologia, pararaaá e tal, na hora de trabalhar poluição.

V- Como se fosse uma situação-problema.

$\mathrm{P}_{7}$ - Isso, uma situação-problema.

V- Agora, historicamente existe algum indício do porque você existe essa disciplinaridade?

$\mathrm{P}_{7^{-}}$Sim, ele existe.

V- Mas é possível romper com isso, ou seja, existe um controle por parte de algum interessado, ou ela existe por uma própria dinâmica em que ao se querer fazer algo, você cai naturalmente na disciplinaridade?

$\mathrm{P}_{7^{-}}$Se você entende que essas coisas, [são as relações sociais,] (9) e as [nossas tradições e formas de organização social,] (10) você está correto, porque não é uma alguém, não é uma pessoa, não é a cabeça dos professores, mas [um conjunto de relações sociais que levam a isso.] (11)Vamos tentar esmiuçar isso um pouquinho melhor, [nós temos uma sociedade que é organizada a partir de profissões, essas profissões são sustentadas numa relação com diplomas, com concursos, um processo de seleção para esses diplomas, concursos e essas seleções para essas profissões. Esse processo seria sustentado pelas disciplinas, as disciplinas servem a esses processos;] (12) por exemplo, hoje você chegar e fazer uma proposta curricular, na qual você diga, não vamos trabalhar por temas, projetos, como fica a garantia de manter a hora-aula de trabalho do professor de química, física, 
biologia, sociologia etc., você põe em crise, por o professor vai se perguntar, será que sou eu que vou dar essa aula, ou será o meu colega de geografia que se formou e trabalhou em um projeto de poluição de meio ambiente? Bem é claro que eu estou simplificando, mas imagine isso em nível social mais amplo, você tem [uma relação das disciplinas num processo de hierarquização e segmentação do conhecimento com um processo de legitimação de algumas pessoas,] (13) ou seja, quem tem o direito de falar nessa sociedade sobre química, não é qualquer um, quem tem o direito de falar nessa sociedade sobre história, sobre geografia; eu posso falar sobre história, mas será que as pessoas vão ouvir com a mesma legitimidade que uma pessoa formada em história, não.

Então, na verdade esse [currículo disciplinar permanece, porque ele atende a essas formalidades sociais: diplomas, profissionalização, hierarquização das pessoas, hierarquização dos saberes, segmentação dos saberes, que atendem essa organização social que nós temos.] (14) Por isso que [os projetos integrados de uma forma geral, eles acontecem, acontecem, mas dentro da organização disciplinar,] (15) ou seja, você vai lá, reúne alguns professores, faz um projeto, tem um horário, dá uma flexibilizada, e é bom que aconteça isso, mas na hora que a gente pensa no currículo integrado, não pode ter uma visão tão ingênua, do tipo, bastou fazer um projeto que eu vou mudar tudo, que não vai por isso; seu diploma permanece e a gente briga. Por exemplo, se eu entro com uma proposta pedagógica que irá tirar química do currículo, ia se um ENEQ todo discutindo sobre isso, nós vamos discutir, defender a permanência da química; então não é um alguém que defenderá a disciplina, nós é que defenderemos, a nossa (risos!).

V- A nossa corporação, ou seja, é algo mais profundo. Talvez seja por isso que em 2003 e 2004 nós tentamos implantar algumas propostas por de trabalhos interdisciplinares por projetos. E aí nós percebemos que enquanto nós fazíamos o acompanhamento, mediava de alguma esses professores desenvolviam os projetos, quando paremos, eles pararam também.

$\mathrm{P}_{7-}$ Porque ele era um espaço à margem, quando vocês paravam essa mediação, as coisas tendem voltar ao suposto natural, que está vinculado a uma série demandas e finalidades de corporações.

\section{V- O qual foi historicamente construído.}

$\mathrm{P}_{7-}$ Sim, e que não é um poder fora de nós que faz, nós também sustentamos as disciplinas com as nossas práticas, esse Congresso, por exemplo, é um Congresso disciplinar. Nós somos disciplinares, no campo da academia, somos disciplinares. Um trabalha com ensino-aprendizagem, o outro trabalha com currículo, o outro com didática, mas somos disciplinares.

\section{V- Eles podem dialogar?}

$\mathrm{P}_{7^{-}}$Dialogar, mas porque, é fazendo uma disciplina que a gente monta grupo, que a gente busca o financiamento, que a gente busca apoio, que a gente cria associações, corporações e que vão sustentando as nossa relações. 
V- Hoje entretanto, parece que há um esforço fazer um trabalho interdisciplinar e contextualizado, para de certa forma chamar a atenção e despertar os interesses dos alunos,ou isso é uma questão de políticas públicas que sinalizam nessa direção, mas em contra partida não dão condições para desenvolver essas práticas?

$\mathrm{P}_{7-}$ Não, não. Porque isso não é uma idéia nova, essas propostas são do século vinte (você pega lá o texto do Dewey, ou a as considerações metodológicas das propostas para a reforma do ensino de química da reforma Francisco Campos-1931), portanto o cotidiano, tarara, essas coisas estas presentes, elas já são discutidas há muito tempo, elas são idéias fortes, é mais o inverso, [a proposta curricular incorpora as coisas que são fortes na (16) prática para a sua própria legitimidade. Tanto, que muitas vezes a mais forte de controle não é a interdisciplinaridade e contextualização, fala-se de interdisciplinaridade e contextualização no nível oficial,] mas para tentar implementar as competências, que é uma grande matriz de controle do trabalho docente, porque a competência tem haver com avaliação, porque a proposta curricular por competência, ela permite depois que a avaliação (ENEM, SAEB) sejam feitas, também por competência, então você vincula o currículo à avaliação, aí pela avaliação você controla o currículo, é uma forma de controle pelas competências. As competências sozinhas elas não teriam tanta legitimidade junto aos professores, quanto elas estando junto a interdisciplinaridade e contextualização. A interdisciplinaridade e contextualização fornece uma legitimidade no projeto mais ampla da política oficial de introduzir as competências.

V- As competências podem ser encaradas como uma necessidade do mercado, ou a competências para construir um cidadão com capacidades de relacionar saberes, é isso?

$\mathrm{P}_{7^{-}}$Também, também, essa é uma idéia que está muito vinculada, de que você precisa de um cidadão mais polivalente, mais flexível, que relacione saberes. Que não deixa de ser uma coisa antiga de submeter a escola ao mercado de trabalho, que é um esvaziamento da escola, toda vez que a gente submete a escola a finalidade de trabalho, ao mercado de trabalho, a gente está diminuindo o potencial cultural da escola; a escola tem que ser importante culturalmente e independente disso, quer dizer, também é uma das funções delas estar relacionada ao mercado de trabalho, mas não só isso. Até porque o mercado de trabalho não precisa da escola, né? Se a empresa não tiver a pessoa formada ela forma. Se ela precisa, ela forma, claro que é mais barato buscar na escola.

V- Pensando nas disciplinas coma dimensão do espaço social, podemos dizer que ela briga com a interdisciplinaridade, ou não, o que acontece?

$\mathrm{P}_{7}$ - Até há sim, mas a prevalência é da disciplinaridade. O que eu consigo perceber é que [o currículo integrado convive com o currículo disciplinar, prevalecendo o disciplinar,] (17) independente da gente achar se isso é bom ou ruim, acontece, ou seja, em umas escolas eles são mais disciplinares, em outras mais integrados, mas ele está presente, com a disciplinaridade prevalecendo.

$\mathrm{V}-\mathrm{P}_{7}$, obrigado, pela disponibilidade e foi um grande prazer para mim esse diálogo. 
Entrevista: $\mathrm{P}_{8}$

Data: 01/12/2005

Tempo Total: $80 \mathrm{~min}$.

$\mathrm{V}^{42}-\mathrm{P}_{8}$, eu tive que mudar o nosso horário da entrevista, em função da antecipação da viagem, e agradeço desde já pela gentileza em concordar e pela disponibilidade.

$\mathrm{P}_{8}^{43}$ - Tomará que eu consiga contribuir.

$\mathrm{V}$ - $\mathrm{P}_{8}$, o meu trabalho é assim, eu vou contar um pouco da minha história para situála, como as coisas estão, fui assistente técnico pedagógico (ATP) do ensino médio na diretoria e nós tentamos implantar uma prática de trabalho por projetos interdisciplinares, foi uma experiência de dois anos. Algumas coisas deram certo outras não. Fiquei curioso em entender essa coisa da interdisciplinaridade, ou transdisciplinaridade, em fim o trabalho dos professores para significar melhor esse conhecimento.

$\mathrm{P}_{8}$-Daí surgiu o seu projeto?

V- Isso aí deu certo trabalhar com a professora Carmen e aí eu estou hoje na universidade, tentado fazer esse trabalho. E nós estamos colhendo dados, entrevistei alguns consultores dos PCNs e alguns professores envolvidos nesse trabalho. E aí surgiu a idéia de gente falar com você. A idéia nossa é justamente tentar entender esse trabalho que a você, juntamente com o seu "Grupo".

$\mathrm{P}_{8}-\mathrm{P}_{2}$ já falou pra você sobre o grupo?

V- Ele comentou como vocês estão trabalhando, que seria com a formação de professores.

$\mathrm{P}_{8^{-}}$E do desenvolvimento do currículo.

V- Isso, exatamente.

$\mathrm{P}_{8-}$ E ele falou os âmbitos que a gente atua? Então, só pra ver se ele já falou, mas também é bom colocar a minha posição.

V- Exatamente acho muito interessante.

$\mathrm{P}_{8}$ - Então, o "Grupo" é interdepartamental de pesquisa sobre educação em ciências; sendo interdepartamental ele associa mais que um departamento da universidade, nós convivemos nesse âmbito, que ele é colado ao espaço físico, nós temos uma infra-estrutura, é um grupo de pesquisa, que nós convivemos aqui neste âmbito, com essas duas linhas que ele falou que é a formação do professor e desenvolvimento do currículo, então é professores da universidade de base de diferentes áreas da nossa área de Ciências Naturais e

\footnotetext{
${ }^{42}$ Refere-se ao entrevistador: Valdir Pedro Berti.

${ }^{43}$ Refere-se ao entrevistado: $\mathrm{P}_{8}$.
} 
suas Tecnologias. Os professores da universidade de química, de física, de biologia, com um pessoal com várias dinâmicas de situações também e além de nós estão os professores da universidade nós temos um número razoável de licenciandos que também lá convivem sistematicamente conosco, estão envolvidos, tanto projetos de pesquisa como o de extensão. Alguns de forma voluntária certo? Outro já dentro de um projeto com bolsa, e também professores de escola que convivem conosco lá nesse espaço. Por outro lado, nós desenvolvemos nossas ações todas articuladas com projetos de pesquisa, ações na formação inicial. Então, nós temos projetos de pesquisa, e estamos no âmbito da formação inicial, então nós filmamos àquelas aulas, entendeu? Porque, tem pesquisa e então tem licenciandos envolvidos, nós atuamos então na formação inicial em aulas mesmo da licenciatura, atuamos na formação continuada.

\section{V- Em qual ano?}

$\mathrm{P}_{8}-\mathrm{Ah}$, em vários anos, dependendo do projeto, eu por exemplo, desenvolvo um projeto em a gente desenvolve daí o atividades dependendo das aulas em disciplinas que abrangem quatro semestres do curso; formação continuada, daí nós temos, então no âmbito que é escolar. Nós também, filmamos aulas em sala de aula no ensino médio.

\section{V- Na sala de aula, onde o professor atua?} escolas.

$\mathrm{P}_{8}$ - Nas escolas que atuam conosco, entendeu? Então, não é qualquer escola são

\section{V- Uma parceria com a universidade?}

$\mathrm{P}_{8}$ - Exatamente, isso aí é uma coisa bem interessante, eu não sei se vou ter tempo de contar tudo para você, mas é por aí, nós temos então o que, algumas escolas com as quais a gente desenvolve ações sistemáticas, desde de desenvolvimento de currículo, para essa escola de formação de professores nessa escola; certo? Com o nosso acompanhamento desses professores na busca de uma identidade, com licenciados que sistematicamente estão planejando junto conosco, junto com os professores daquela escola, planejando as tais "Experiências Relacionadas coma a Realidade (ERR)" e daí são desenvolvidas na quinta série, na sexta série, no ensino médio. A gente filma essas aulas também, são aulas na licenciatura, na escola e em encontros de formação continuada. Eu, por exemplo, acompanho um processo de formação continuada, no âmbito do qual eu desenvolvo minhas pesquisas, eles se constituem em encontros mensais de quatro horas de duração, teoricamente a gente tem já esse processo, com uma secretaria municipal, uma situação da Universidade com a prefeitura. Todo mês durante quatro horas, na segunda-feira pela manhã, uma vez por mês (já foi quinzenal) hoje é uma vez por mês. São doze escolas, onde tem professores de ciências, do ensino fundamental e médio e eles têm mensalmente esses encontros de formação continuada, nesse âmbito também, a gente está lá com o "Grupo", em síntese o que eu estou falando para você, não falei tudo, mas em síntese essa é a atuação do "Grupo". Uma coisa importante, também é que a gente articula formação inicial com formação e a formação continuada dos professores da escola e da universidade, nós temos também, a nossa formação continuada, damos aulas na licenciatura, trabalhamos com extensão; enfim, na formação e a nossa formação continuada, também se dá nesse âmbito e 
articulamos o que, a formação de professores inicial e continuada com o desenvolvimento de currículo desde de mil novecentos e noventa e nove, de dois mil de para cá a gente tem desenvolvimento de currículo, nesta modalidade nós chamamos de "ERR". Essa é a nossa organização curricular hoje que a gente busca desenvolvê-las nas escolas nossos âmbitos são de estudo, planejamento, desenvolvimento em sala de aula, e com avaliação, acompanhamento, re-construção das "ERR", esse é mais ou menos o âmbito que estou dando para você que é o do "Grupo".

V- Como se dá a produção desse trabalho, por exemplo, porque nós estamos falando de dois momentos, do professor em situação de formação inicial ou continuada. Vocês desenvolvem esse trabalho com a participação do professor, ele tem participação nesse desenvolvimento, como isso ocorre?

$\mathrm{P}_{8}$ - É o professor da escola que você está falando?

V- Isso. Ele é convidado, nós temos esse projeto, ele já está escrito, ou os professores participam dando a sua opinião, como funciona isso funciona?

$\mathrm{P}_{8}$ - Isso também, a gente está desenvolvendo no processo, mas o que acontece é que nós inicialmente tínhamos poucas "ERR", o "Professor" já falou para você sobre nossa concepção dentro da "ERR", você já entende o que isso? Em poucas palavras, a "ERR" é uma situação em estudo, ou seja, [uma situação identificada na vivência das pessoas] (1) ali envolvidas, no caso, na escola, na licenciatura, também os meninos da formação inicial vão identificar uma "ERR", eles vão ter professores envolvidos, os professores nem sempre estão na escola, às vezes, eles estão planejando em âmbito universitário, mas de qualquer forma, a "ERR" no primeiro passo, há identificação de [um recorte da vivência social daquelas pessoas] (2) que são os estudantes, os professores envolvidos e esse recorte pode ser do âmbito escolar, usualmente ele não é, ele é da vivência pós-escola. Esse recorte trazido da vivência das pessoas do cotidiano; enfim, é um recorte que a gente preferencialmente busca encontrá-lo, identificá-los no sentido de serem conceitualmente ricos para diversos fins. Então, vamos supor que eu poderia fazer estudos na escola sobre essa caneta, sobre esse gravador, sobre o seu celular; agora para estudar sobre o ponto de vista conceitual interdisciplinar uma caneta, eu posso pensar que isso pode me permitir estudos durante três meses numa escola, mas posso pensar em atividades num âmbito mais amplo, mais potencialmente rico, embora é claro, eu posso pensar que tem alguma coisa haver com estudo na área de biologia, posso levar essa caneta para uma sala de cirurgia, assim como está aqui? Então, tu começas a ver que nesta caneta que está aqui; ah! Eu me lembro quando a gente foi estudar uma "ERR" que estava bastante desenvolvida que era do ar atmosférico, esse ar atmosférico não é aquele ar como conteúdo assim a ser estudado, ele é o ar que a gente respira, cada ar é ar, não é aquele genérico, naquela época o pessoal se preocupava, mas será? Porque parece que era mais química ou física. Todas as questões da física, em química tantas opções, transformações, mas quando a gente vai ver, meu Deus! O ar começou assim? Como era a atmosfera primitiva e aí vem a fotossíntese, vem não sei o quê. Começa a estudar doenças que a gente não enxerga, mas só tem substâncias no ar? Ou tem também esporos, enfim bactérias, vírus. Inicialmente, teve uma "ERR" que se chamou Dengue e Leptospirose, ela tem identificado também, dependendo dos interesses que há naquele momento, essa por exemplo, era um processo de formação continuada com 
professores e em um dos encontros houve a solicitação do espaço, por parte do processo que estava lá, que era uma campanha que envolvia todas as escolas sobre a prevenção de Dengue. Então, foi aberto um espaço e gente estava lá para trabalhar com "ERR" foi feita uma divulgação da campanha, o pessoal tinha material pronto, isso foi a motivação para esse grupo eleger Dengue Leptospirose como "ERR", nesse caso a impressão que a gente teve no primeiro momento que provavelmente vai estar potencialmente presente a área de química, por exemplo, química e biologia neste caso estão muito presente, mas dentro de Leptospirose será que vai? Mas, aí o que a gente fez, nada tão forçado, tem que haver de forma equiitativa a potencialidade de inserção de todas as áreas.

\section{V- Quer dizer que algumas áreas podem contribuir menos?}

$\mathrm{P}_{8}$ - Ela pode ou não abranger todo o movimento conceitual por um lado daquela relação que pode ser física e aí eu vou dizer uma outra parte da "ERR", agora que vou entrar nesse aspecto, como é que gente trabalha isso, você faz uso de plano de aula e insere qualquer uma delas, a gente busca então, a "ERR" que foi produzida ali e ela é conceitualmente rica e gente pensa que durante dois ou três meses na escola, ensino fundamental e médio, o ensino vai acontecer de forma em que química, física e biologia, geologia e matemática, enfim, eles tivessem contribuindo no estudo dela, ela é a nossa peça fundamental, e gente busca, estudar, problematizar essa situação e aí o que a gente tem, os conteúdos e os conceitos e gente tem feito essa discussão que foi distribuída já, né? Conteúdos e os conceitos, uma vez certos eles entram na problematização e no desenvolvimento conceitual das pessoas e aí nós temos por um lado [um enriquecimento de linguagem, ou seja, na hora que a gente vai trabalhar conceitualmente na situação, do ponto de vista da química, o que vai acontecer novas palavras] (3) desse sujeito vão passar a usar, então a gente trabalhar na perspectiva de que os conceitos, em primeiro lugar são palavras, palavras que esses sujeitos vão se apropriar delas, a gente busca isso intencionalmente trazer mesmo esse enriquecimento da linguagem das pessoas e que essa palavra precisa ser de significado, conhecer o sujeito, então a construção do significado dos conceitos, por exemplo, no caso da química, a que está entrando de conceito em todas as situações, então nós descrevemos as situações, planejamos as situações intencionalmente a primeira é a palavra substância, às vezes, você corre o risco de trabalhar tantos estudos contextuais e a gente não usar a palavra substância de forma que permita ao sujeito reconstruir as suas idéias, reconstruir significados para palavra, isso também tem que ser analisado, então veja bem, isso tem um duplo sentido, a gente trás as palavras, conceitos e com essas palavras e conceitos a gente vai trabalhando conteúdos, os conteúdos usualmente eles não retornam tantas vezes de uma situação de estudo para outra, mas os conceitos retornam nós temos já uma relação de conceitos de física, de química de biologia, que retornam em todas as "ERR", a gente considera que esses conceitos são estruturantes daquele componente disciplinar.

\section{V- Ele é então intencional?}

$\mathrm{P}_{8}$ - Por um lado às situações vivenciais vai possibilitar diálogos, problematizações; enfim, Só que nós fazemos as problematizações com essa intencionalidade de conceitualização. Nós temos isso muito marcado uma forma seria problematizado, saberes do sujeito, o recebimento do sujeito, se eles vão expressar com suas palavras e 
conseqüentemente define um e esquecer o outro; enfim, o professor até vai entrar, mas sem aquela intencionalidade de no contexto interativo ali, onde todos têm que falar, porque sempre tem o que dizer sobre aquela situação que é precípua, né? O professor tem essa intencionalidade de introduzir conceitos no contexto, então você vê por um lado no espaço químico você tem essa ruptura do lado da química para o lado mais vivencial, vamos dizer assim, onde ao invés de você está falando vou dar a palavra para o estudante e não é uma situação forçada, porque eu quero que a química contribua com sucesso na compreensão daquela situação. Vou usar a palavra substância, por exemplo, no contexto físico e tal, então está muito claro para nós (nada é forçado), mas a gente não vai só usar a palavra e ponto, a gente usa a palavra e daí o que acontece, quando vem substância, logo junto vem elemento químico. Você é da área da química?

\section{V-Sou.}

$\mathrm{P}_{8}$ - Então, vêm elemento químico, misturas, materiais e vem transformação química, veja bem, um conceito desses estruturantes demanda outro; nós temos um conjunto de conceitos centrais. Então, por exemplo, eu trabalho com professores nesse âmbito da rede municipal, um tempo atrás uma "ERR" eles estavam planejando de propriedade rural (tem muitas escolas do meio rural), então, em cada escola o professor com os estudantes visitavam uma propriedade rural e eles iam ficar no sítio, depois houve o problema que a situação era muito ampla, a horta na propriedade rural já seria uma "ERR", são várias as situações que se tem, mas quando se visitou a horta, surgiu a questão dos adubos. O NPK, a professora desses alunos escola de ensino fundamental era formada em Biologia e não tinha esse domínio; então, nós interagimos com os licenciandos nossos da universidade com esses conceitos todos de forma assimétrica, a gente não sabe se vai precisar mediar com eles esse conhecimento, você está na Oficina Pedagógica, você tem essas situações. Então, nós não deslocamos da nossa condição do nosso papel assimétrico, da nossa mediação em condição assimétrica nessa interação. O que aconteceu a professora com os estudantes fizeram a proposição na escola de se chamar um agrônomo para interagir com eles a respeito dessa questão dos adubos que eram usados na horta. Eles tinham visitado as informações que constavam no saco do adubo, o NPK (Nitrogênio, Fósforo e Potássio), a professora ficou muito encantada, porque ela, sinceramente, estava cega, né? O NPK ela já sabia que comparece na Tabela Periódica; mas para a professora NPK já era a substância que estava contida no adubo, que tem no solo e que a planta absorve, então esse NPK estava no ciclo do ar, que eles estudam naquelas aulas de ciências, estava tudo perfeito quando veio o agrônomo e ele também não trabalha conceitualmente do ponto de vista da química, deu-se praticamente a mesma situação, ele fez basicamente a mesma leitura, com esse entendimento com esse significado, o NPK está na Tabela Periódica já é a substância, o nosso papel diferenciado nesse momento; espere aí, é substância ou elemento e a professora não sabia mais dizer, pois para ela substância e elemento era a mesma coisa. Substância e elemento são definidas muito rapidamente nas nossas escolas, no ensino de modo geral, na universidade. Não se debruça a prestar atenção no significado, no conceitual. Então, o que acontece, demorou muito tempo, tivemos outras situações tantas e para a ficha dela cair e depois ela descobriu num passe de mágica, de repente, porque são princípios para nós da química, mas representava para ela assim NPK, qual é fórmula da substância, qual o elemento nitrogênio comparece ali naquele adubo, ela não entendia a minha pergunta, ela dizia assim: tem o $\mathrm{N}$ e tem o K seria nitrato de potássio? Então, neste 
caso tem uma substância o nitrato de potássio que está contribuindo no adubo, tanto em agregar a presença dele nesse nitrogênio como nesse potássio, mas será que é nitrato de potássio? Será que potássio? É sulfato? Agora recentemente no mesmo grupo, por exemplo, a gente estava estudando, eles planejando uma "ERR", para oitava série, eles pensam assim, que até as aprendizagens anterior a oitava, a gente já vai fazendo muitas iniciações no conhecimento químico, a gente compreende que na oitava série mesmo que entra o nível atômico molecular, então eles já vão usando a linguagem química, por exemplo, usam a Tabela Periódica, mas quando surge na quinta série, equação da fotossíntese, equação da respiração, não é nova a química que vamos colocar, porque ela já está lá, com a "ERR" a gente [busca romper a linearidade,] (4) não tem mais fotossíntese aqui, corpo humano lá.

\section{V- Aquela coisa fragmentada.}

$\mathrm{P}_{8}$ - A "ERR" da propriedade rural se fosse na sétima série, se fosse na quinta, bom, mas, em todo o caso, eles estavam estudando e estão em fase de planejamento de uma "ERR"que seria para oitava série. Como as escolas deles ainda não tem muito a "ERR", esses alunos estão chegando na oitava série com conhecimento da biologia. Então, eles querem fazer nesse período que está em fase de mudança nas escolas o ingresso na oitava série uma "ERR", onde eles vão trabalhar com as relações entre respiração e fotossíntese, que já foi trabalhado antes, mas agora sob um aspecto articulador, como que isso transforma o meio, a atmosfera, etc. Então, eles estavam estudando a presença da clorofila, das plantas e surgiu a questão, a clorofila é substância, eu já tenho discutido muito com eles, proteínas para eles Então, eu digo para eles que proteínas é uma classe de substância, se você falar que no leite eu encontro a caseína, que está no queijo, gente sempre vai depender de um aspecto do conhecimento químico, que a gente já estudou e que vai com autoridade nos dizer caseína é uma substância, que a hemoglobina do nosso sangue é uma substância, agora a nossa hemoglobina não é exatamente igual a hemoglobina do sangue do cavalo. Então, a gente tem essa discussão, porque nós temos substância, e temos classes de substâncias, carboidrato é substância? Hoje eles sabem dizer, que não carboidrato, que é uma classe de substância, porque eles sabem que amido é carboidrato, glicose é carboidrato, lactose do leite é carboidrato, não importa o tipo de discussão que a gente vai usar, mas no contexto, eles usam adequadamente, e aí a gente tem feito assim, não é que se vai dizer se é substância ou não, tem que sair daquela condição em que o professor é aquele que já sabe, eu tenho as respostas, eu sou aquele que já sei; então surgiu a questão da clorofila, a clorofila é substância? Os licenciandos têm um papel muito especifico aí, porque eles estão numa fase de formação inicial e eles vão muito à fonte, pesquisam; e num instante eles entram na internet já trazem um monte de coisa, vão para a universidade falam com o professor, trazem, integram o texto lá na escola, por exemplo, eles estão lá planejando junto aos professores tem um papel importante pra eles, é importante essa interação lá e eles contribuem. No meu caso também, quando estou precisando e não tenho tempo, (nós que somos professores estamos na ação mesmo), sabe como é nossa vida e nas escolas, também. Então, o que acontece, a clorofila, a gente tem feito, assim, o que é substância, eu tenho feito com eles, mas mesmo antes do "Grupo", na licenciatura a gente trabalha assim, quando não encontro uma fórmula química daquela identidade de substância, digo que isso é uma substância, alguém vai ter que me ajudar a responder isso, tem uma fórmula química representativa, enquanto substância aí eu tenho que entender, ah bom, isso sempre tem um equilíbrio, então lá pelas tantas os licenciandos trazem a fórmula 
da clorofila. $\mathrm{O}$ entendimento era o de que a clorofila era uma substância, não demorou muito em que aparece a clorofila $\mathrm{A}$ e $\mathrm{B}$, que tem uma pequena diferença na fórmula química, mas que existe; entendeu? Então a clorofila já não é mais uma substância só, tenho a clorofila A e B. Essa discussão se você prestar atenção, na aula de química, na formação continuada e inicial, ela nos escapa, porque se gente não entra com a disciplina, do ponto de vista químico, naqueles conceitos que não forem significados, usados adequadamente, no contexto, não é genérico, então faça isso é tão significativo.

$\mathrm{V}$ - Me parece que no geral fica no genérico.

$\mathrm{P}_{8}$ - A situação de estudo é conceitualmente rica para diversos tempos e ela tem por um lado, a possibilidade de que ela abarca, vamos dizer assim, de forma melhor, a possibilidade de a gente estar trabalhando com conceitos e conteúdos. Então, aquele conteúdo nosso, aquele conceito, ganha um novo lugar de importância de relação de inserção, no processo de ensino da formação do sujeito, então você nota essa contribuição da "ERR" e por outro lado como esse conceito a situação fica possível de passar por um outro nível de compreensão e de ação; Agora estou vendo uma situação com um grupo que está trabalhando com cosméticos e produtos de limpeza. A gente começa levantado rótulos e vai e aí de novo começa na assim, que substâncias que são usadas precisam ser conhecidas; então eles vão ter dúvidas novamente, quem já estudou na escola mesmo, no Ensino médio, vai falar, ah, não está aqui cloreto de sódio, já sabe que isso é substância, água isso é substância, tem várias substância, aí aparece uma categoria de ingredientes que eles ficam em dúvida, então, por exemplo, os sais sódicos de ácido graxo, por exemplo, eles ficam olhando, como é mesmo?

\section{V- E agora?}

$\mathrm{P}_{8}$ - Como era mesmo? Não, era uma designação que seria, por exemplo, ácidos graxos e sal de potássio, bom, o nome dava a entender pelo visto, mas daí eles vão explorar, não, mas aqui eu posso ter vários ácidos graxos, todos são sais de potássio, eu posso ter o esteriato, palmitato, eles vão vendo se é substância, se é uma classe de substância e alguns ficam desconhecidos mesmo, pois nunca ouviram falar e alguns vão olhar para o ingrediente que está ali, junto com cloreto de sódio e está escrito óleo de girassol, ou extrato de rosas, é um ingrediente, eles já vão me dizer, não, isso de longe não é substância, nem uma classe de substâncias, isso é uma mistura. Bom, provavelmente vai ter um ingrediente principal, então eles vão chamando assim, isso também é feito na física, na biologia e a gente percebe que, por um lado, os conceitos e conteúdos disciplinares vão sendo trabalhados e gente vai procurando mapear isso; na hora que a aula é desenvolvida em sala de aula com alunos, como uma "ERR" em ciências, de química do Ensino Médio, não mais química ou física é ciências naturais e tecnologias da área, nesse momento a gente se preocupa em que esses conceitos e conteúdos compareçam como disciplina, então a gente diz [o interdisciplinar em primeiro lugar precisa do disciplinar,] (5) não existe o inter, o transdiciplinar se não tiver o disciplinar nesses estudos, a gente tem muito claro no processo todo e veja bem quando se vai para sala de aula, já há ou houve o planejamento; então, o que acontece é que já existe isso relacionado, já se sabe que depois de dois meses, espera-se que, pelo menos, esse conceito e claro que muda de uma situação para outra, entendeu? Sabe-se que esses conceitos vão entrar na química, por exemplo, se for analisado 
química, física ou biologia e há também, alguns conceitos que a gente está chamando de interdisciplinar, ou seja, a energia, por exemplo, que nós na química trabalhamos a palavra, o conceito de energia, ele agora está assumindo uma outra dimensão, porque além do nosso modo de significar, de usar a palavra energia junto com essas inserções, a gente percebe que energia, agora está num outro âmbito e que não é mais o disciplinar; então algum conceito nós estamos colocando, devagarzinho, estamos estudando isso, como conceito de inter, transdisciplinar, sei lá como a gente vai ver isso.

$\mathrm{V}-\mathrm{P}_{8}$, só aproveitando, esse conceito de energia, me parece que uma idéia maior e que poderia ser um conceito interdisciplinar;

$\mathrm{P}_{8}$-Poderia ser em alguns cursos ele vem sendo considerado e relacionado, já houve publicação que saiu, onde tem química, física e biologia e aí aparece a coluna dos inter e energia é um dele.

$\mathrm{V}-\mathrm{P}_{8}$ você poderia fazer, não sei se é possível, mas há uma diferença, por exemplo, eu na disciplina indo para outras disciplinas, o que me leva para interdisciplinaridade, mas quando eu iria para a trans, você teria assim, um exemplo?

$\mathrm{P}_{8^{-}}$Em primeiro lugar a gente tem lá no "Grupo" um certo cuidado com os sujeitos com os quais a gente trabalha, de não entrar muito nesses rótulos, que às vezes a pessoa se satisfaz por entendida, demora tanto, o que é mesmo inter, multi, pluri, trans? Bom, o intercomplementar que nós usamos, o interlacional, tem tantos nomes, além do inter, multi, pluri, tem palavras que mantém. Na nossa formação, a gente não leva isso. Nos nossos textos você não vai encontrar mulit, pelo que me lembro nunca vi em nenhum texto dizendo mas, na licenciatura, na pós-graduacão, enfim a gente trás esses textos e gente lida com essas diferenças, como é que eu percebo, não é nem o grupo, sou eu, que num certo estágio de envolvimento do sujeito há uma tendência de aparecer mais uma hipótese que eu vou chamar de multi, pluridisciplianar, isso é uma etapa mais direta, mais fácil, isso passa por aí, eu sempre valorizo, mas às vezes tu podes ficar assim, mais isso já é interdiscipinar, não importa também esse rótulo. Então, vamos dizer assim, numa escola cada professor fala contribuindo com a sua disciplina, o de química, o de biologia, do Ensino Médio , de física enfim, tem escolas que estão envolvendo todas as áreas, professora de português, de educação artística, de matemática, de história, de geografia, mas nós do "Grupo"nos ocupamos da área de ciências naturais e suas tecnologias e matemática que está entrando agora. Então, nós nos assumimos como uma área, historicamente, nós éramos um departamento de ciências dentro da Instituição, depois nós nos dividimos, hoje nós somos o departamento de biologia e química e há outro de física e matemática estatística. Nós nunca deixamos de conviver com a área de física, nós temos biologia e química e a área de física sempre trabalhou com nós, nesse âmbito que é o nosso grupo que a gente chama de educação em química, então o que acontece na formação a gente não calça muito essas diferenciações, mas a gente, o que é que eu digo, se eles tem [cada professor, uma contribuição] (6) e aí o professor sabe que ele está trabalhando essa caneta, mas ele sabe que neste momento, na semana passada e na semana seguinte, o professor de química também deu está caneta, [mas ele não sabe o que é direito, o que é que está de repente sendo envolvido no processo em que nas escolas] (7) dentro daquelas campanhas, os estágios, não sei o que, e toda a escola, eu chamo isso de pluri, multidisciplinaridade, 
porque [não há esse trânsito, esse entrecruzamento, essa invasão de fronteiras,] (8) um dos outros, esse planejamento, onde no planejamento vai mudar um pouco, porque eu sei que aquele professor está trabalhando com o mesmo aluno que eu vou trabalhar, eu estou trabalhando com a química, mas eu sei que lá eles estão trabalhando também, tentando trabalhar todo conceito e que tem alguma coisa haver conosco, na hora que a gente planeja, e a outra coisa que eu vejo, lá funciona muito essa situação de estudo, quando não é assim, de uma forma que a gente concebe, o acompanhamento e a avaliação depois no aprendizado do aluno, é feito sempre separado, não se conseguem perceber, muito de diferente, na aprendizagem do aluno pelo fato de foi estudado durante uma semana, não sei quanto foi, um mês, aquele assunto comum. Então, o que eu digo para eles, ainda não é o que poderia ser, mas que bom que vocês estão fazendo isso.

\section{V- É um avanço.}

$\mathrm{P}_{8}$-E a gente pode mostrar os limites, um pouco disso. Então, a nossa concepção de planejamento é diferente e aí vem uma outra coisa da "ERR", não vou falar todas, mas uma que eu vou falar agora, essa "ERR" não é só um desenvolvimento de currículo, vamos supor separado do contexto escolar ou universitário, enfim da formação continuada da sua diretoria, não é separada no sentido de que esse sujeito que está planejando essa "ERR", enquanto possível, sempre tem a dimensão que se planejamento tem haver com prática deles mesmos, é uma prática com a qual a gente está comprometida e nesse sentido tem que ficar sempre atento com as condições existentes para que esse planejamento não fique naquela coisa do papel, por isso é difícil superar, às vezes, o multi, o pluri, para que a gente chegue no inter e no trans, no intercomplementar, enfim; [é necessário um planejamento conjunto a tal ponto que o professor que está contando o que iria trabalhar, o que ele já trabalhou ] (9) no ano passado, o que ele agora está pensando em trabalhar, os vídeos que eles vai disponibilizar para os alunos e se aqueles vídeos vão ter intertextualidade para o professor dar aula de biologia, de física e fazer o gancho com os conteúdos, se vai também inserir e vai estar chamando a atenção para essas relações, se a gente tiver isso como proposta paralela, com a ilusão que o aluno vai fazer as relações o mesmo na licenciatura, quer dizer, a gente prega o interdisciplinar, achando que depois eles vão chegar na escola e vai haver as condições por parte dele e mesmo do planejamento, da moção da escola, enfim. Então é um pouco que eles fazem para superar, a "ERR" é mais do que aquela situação em si, ela é na verdade uma nova organização da vida das pessoas é opção de material didático, que o professor está produzindo, para publicar inclusive, mas a autoria está muito complicada, porque, às vezes tem uma "ERR", por exemplo, vou te citar um exemplo do ar atmosférico, essa situação de estudo elas se iniciaram em grupo e aí há planejamento, sempre há o planejamento inicial; respondendo aquela pergunta de antes, a gente começa sempre com um planejamento, nunca com uma prática na sala de aula, vamos lá e vamos ver o que sai, nunca foi assim, a gente diz claramente; então não é "ERR" é outra coisa, a "ERR" é uma concepção, é um outro modo de vida, quanto a hegemonia do currículo, planejamento e execução, ou seja, na formação, então veja bem, no primeiro momento tem sempre um grupo que pode ser uma escola, que já é um caso que tem uma escola, foi uma licenciatura, sabe, foi na formação continuada, começou num grupo de professores de várias escolas, numa formação continuada, Ar atmosférico, começou, Ar Atmosférico, a primeira vez, começou no planejamento, mais articulada com a proposta do novo Ensino Médio, mas você percebe que elas vão iniciando num âmbito e depois vai, 
você tem uma outra escola, na licenciatura, a gente tem linhas de componente curricular das licenciaturas e no caso do nosso currículo mais antigo, nós tínhamos quatro disciplinas de cinqüenta horas, não é tão pouco, quatro de cinqüenta horas, só que todas para se trabalhar com "ERR" é um tempo grande, usualmente em cada uma, num primeiro momento era apresentada já uma em fase adiantada, então o primeiro período das sessentas horas era a vivência de uma "ERR", já existente, mas ela nunca tem em nenhum ano já aprovada, ela vem como ponto de partida, e sempre se faz planejamento de novo, Então, ela é apresentada como existente, quando ela já está existe, todos os anos, mas a princípio a gente não queria publicar, também, porque quando tu publica engessa, mas a gente está fazendo num formato, assim, bem simples de tal forma que ela possa, sempre estar sendo enriquecedora escola com as contribuições que virão do contexto.

\section{V- De acordo com a necessidade.}

$\mathrm{P}_{8}$-Então, a questão da autoria que eu estava falando, é uma questão que a gente até tem um pouco de dificuldade de lidar; eu estou, com um número de sujeitos, que desde primeira produção, claro que já tem o nome do autor, bom, depois ela passa para uma turma de alunos da licenciatura que estão lá, trinta sujeitos, mas eles também contribuíram com mais uma superação, eles entram também, mas agora temos uma escola, onde temos seis professores mais três ou quatro licenciandos, também mexeram e tem participação, por outro lado, ah, mais eu também lá pelas tantas e começa a já sair meu nome, então é uma dificuldade, mas essa é a visão e aí eu acho muito importante dizer que se pode ser [interdisciplinar, mas em primeiro lugar temos essa visão da importância do disciplinar que é algo que não tem quer ser acrescido, mas é a primeira condição é a presença forte muito mais do que era apenas disciplinar], (10) [o interdisciplinar e o disciplinar ganham outro lugar de valor, de inserção, de importância,] (11) então a nossa química, tem gente que acha por causa do projeto interdisciplinar precisa-se abandonar a química, né.

\section{V- Essa é a grande crítica.}

$\mathrm{P}_{8^{-}}$Nós temos muita clareza que para nós, nem precisava dizer, já está dito interdisciplinar, então a primeira coisa é, e a segunda, [não há uma super junção da biologia, da física e da química, não é muito mais que isso, é uma nova forma da organização da vida das pessoas, no estudo delas, na formação delas, planejamento, no acompanhamento,] (12) o licenciando está só observando, o professor da escola, estamos envolvidos em fazer juntos, então, o acompanhamento num propósito de gente ver que tem que estar sempre reconstruindo. Então, é muito importante dizer que nesses grupos, muitas vezes, assim como a proposta deles juntos de superação, porque se é uma nova vida das pessoas implica em condições, então nós já temos escolas, onde essas condições já foram melhores e aí depois muda a realidade, tem até um relato, um depoimento que vou trazer hoje aqui, onde a professora diz, se expressa assim, como é horrível agora ter que voltar à trás, onde ela teve naquela escola que é totalmente disciplinar, onde viveu fazendo a mesma coisa, quando viveu a outra situação, porque ela vinha perseguindo essa mudança, então se não há condições, não é o professor precisar fazer sozinho, a outra coisa importante é o comparecimento desses especialistas, não é só com os professores de biologia, tem uma escola, por exemplo, em que os professores de ciência do Ensino Fundamental, isso não é muito cuidado quando entra concurso, enfim; ele está habilitado e não importa se ele veio 
falar da química, até da matemática, da física, da biologia para o Ensino Fundamental. Então, não tinha professor de química, com formação na química.

\section{V- Geralmente esses professores são formados em biologia.}

$\mathrm{P}_{8}$-Isso já é um problema, então, a gente entende que a presença de quem já se apropriou daquela cultura, aquela linha, do que representa, e vai ter que se buscar muito, sem falar frente a situação contextual, nosso âmbito conceitual, enfim com estudo na nossa cultura da química, ele sempre vai estar muito submisso, mas a gente sabe, onde encontrar o que a gente não tem, as informações que a gente não tem ainda; então, isso é uma coisa importante, deve-se ter as condições, e é claro que com as "ERR" e com o "Grupo" também, a gente tem assim uma ampla abertura, claro, em termos de mudança de todas as metodologias, de acesso de informação, entendeu, e os recursos que se usa na sala de aula, não dá mais para pegar o livro didático e simplesmente seguir e também, nós defendemos a manutenção do livro didático; então no livro didático, assim como ele está organizado na forma tradicional, tomara que ele nunca saia da mão e de perto do professor, porque na hora que você tem que buscar, aquele conteúdo que já está pronto, aquela explicação, aquele, sei lá, ah tá aquela parte que está naquele livro que você vai encontrar, nesses outros livros agora que são dessa outra forma, às vezes, até o professor demora mais até a achar aquilo que ele precisa naquele momento. A ordem, a gente supera com a "ERR", principalmente a linearidade. Então, significa que não há mais aquela diretividade do programa tradicional, cada conteúdo naquele momento, pronto, e a fragmentação, pensando que não é apenas disciplinar, enfim E isso, eu digo que é uma demanda hoje, do enfoque dentro da reforma, que hoje é chamada de contextualização e essa contextualização, traz tanto, as implicações de que há uma história desse conhecimento, dessa nova linguagem que a gente vai estar disponibilizando e usando, o quanto possível na licenciatura, na pós-graduação, sempre a gente tem que estar atento a isso, nem sempre dá para isso na escola, mas quando possível fazer essa contextualização, também, a historicidade não a história em si, mas mostrar essa dimensão de que, porque essa linearidade, essa fragmentação, enfim, aquela sessão, de repetir com as mesmas palavras e pronto. $\mathrm{O}$ aluno aprende, o professor está acomodado, não venham brigar comigo, porque, ele aprende sim, olha aqui as notas, eu sou exigente em média é sete, mas eu estou satisfeito com a média sete, comigo todo mundo vai aprender mesmo, e eu sou exigente, olha aqui as provas, mas não estão preocupados com as implicações desse aprendizado, com o tipo desse aprendizado, a durabilidade dele, a significação dele, e aí hoje, claro, com todas as avaliações que tem sido feita aí, a gente tem a convicção de que não dá mais para continuar e eu acho que na medida em que o professor tem essa consciência, a gente tem motivado, eu vejo assim muito o fator que um vai contaminado os outros, nós temos um grupo já hoje, mínimo, fortalecido, muito pequeno, sim, mas o mínimo, constituído, vamos dizer, para acreditar que não vamos voltar atrás acreditarmos nisso, agora é muito difícil, tá., a gente, às vezes, se pega, ainda, caindo na velha racionalidade, de achar que porque a gente está entendendo, o professor já vai entender, né. Quando a vê o resultado, isso aqui não tem nada a ver, na verdade eles trocaram um pouco aqui e alguns colegas entre nós e a gente fica desesperado, não pode né, mas é assim, entender o que esse afetamento de uns aos outros.

\section{V- Essa mudança é muito}


$\mathrm{P}_{8}$ - é algo muito profundo, não pode ser vista como uma mudança superficial.

V- No caso, quando trabalha se trabalha com "ERR", eu faço um recorte, porque eu estou pegando uma situação, porém a crítica que se faz é a seguinte, o conteúdo é trabalhado com uma certa superficialidade, essa é a grande crítica, e tradicionalmente nós temos no Brasil uma cultura propedêutica, de vestibular. Como vocês estão trabalhando isso, está se fazendo esse recorte no conteúdo, não está sendo feito o recorte? Os conceitos trabalhados são suficientes?

$\mathrm{P}_{8}$ - Acho que entendi a sua questão, como é que é o nosso discurso, e quando eu digo discurso é com isso que a gente quer influenciar todo mundo, o discurso é o nosso entendimento e nós temos assim, convicção de que temos essa intencionalidade, e na formação inicial e formação continuada a gente estabelece as nossas inversões, situações, onde a gente vivencia na verdade essas situações com essa clareza do nosso papel aqui que é de se opor, e a ruptura que a gente está fazendo, com as situações de estudo, [é uma ruptura que implica em a gente superar mesmo a lista dos conteúdos, a lista, a linearidade com que está organizado esse conteúdo, essa fragmentação,] (13) e é isso que eu digo para você, que é difícil. Então, é isso que a gente quer, agora a gente tem junto com isso, acredita mesmo, que é possível romper com a lista, sem de jeito nenhum, deixar fora o conteúdo do conceito, porque daí é claro que, toda vida a gente vem dizendo que nós também precisamos fazer alguns enxugamentos, eu me lembro que quando estava bem envolvida na escola que a gente trabalhou com ar atmosférico no Ensino Médio, onde está mais presente a visão propedêutica do vestibular e tudo, né. Essas escolas são as que têm preparação para o vestibular tão forte, quanto o ensino, não é assim, vamos trabalhar contextualização, cotidiano e interdisciplinaridade e aí? Não, a gente pretende sempre dar conta de forma melhor do que a escola estava dando antes, dessa dimensão da formação mesmo para depois ir para a universidade no vestibular e se sair bem na vida. Então, a gente diz assim, não queremos separar a formação, a preparação, enfim, o papel da escola de ajudar no desenvolvimento do sujeito, pensando que ele tem uma vida que está pela frente, que tem uma vida que está ali hoje e que essa vida, nesse desenvolvimento desse sujeito na vida dele não fica separado o componente esse que a gente chama de profissional, ele vivendo como cidadão, que vive em qualquer âmbito do mundo, da vida total dele, a vida social dele, enfim nas aspirações em todos os âmbitos da vida deles; então, ele vai aprender ciências, vai aprender química, dentro de ciências, numa forma contextualizada, vivenciada, com a qual ele compreende e age no mundo de uma forma que permita desenvolver justamente a inteligência dentro dele, então ele tem um outro lugar de visão no mundo, o outro lugar que eu digo é o desenvolvimento dele mesmo, o desenvolvimento humano; esse conhecimento que ele tem não tem nada a ver com a repetição, com as mesmas palavras, um conteúdo que está numa gaiolinha certinha, que se não for perguntada fora da gaiolinha, ela não lembra mais como era e é assim que é.

\section{V- Compartimentalização.}

$\mathrm{P}_{8^{-}}$Isso que dizer que você ensinou de um jeito, nós temos uma outra visão, temos fundamentado, mas que eu não vou dizer agora, imagino que ele deve ter falado para você a constituição da mente do sujeito; você deve ter ficado por dentro. Veja bem, o desenvolvimento para o segmento do fluxo da escola, pensando no Ensino Fundamental, 
médio, do vestibular, da universidade, tenho dito assim, seguidamente o que, uma boa formação, uma boa preparação desse sujeito, um bom desenvolvimento desse sujeito, enquanto preparação para o vestibular, para mim em primeiro lugar implica uma boa preparação, uma boa formação no desenvolvimento desse sujeito para a universidade, para a profissão, depois da universidade para a vida como um todo, não é uma coisa ou outra, ou vou prepará-lo para a vida, ou para o vestibular. Então, vou falar um pouquinho sobre o vestibular e a universidade, a gente trabalha na universidade, a gente trabalha na universidade, qual o melhor aluno que a gente tem nas nossas aulas, ou aquele que está repetindo tudo igualzinho, como não dou aula desse jeito, a gente quer que os nossos alunos raciocinem, expressem, pesem as idéias deles, misturem às nossas novas formas de falar, explicar e de entender o mundo, e que isso os ajudem a falar do jeito deles recriando, quem sabe até da forma deles, esses olhares, essas compreensões. Então, tenho dito seguidamente para os professores que bom que vai preparar para o vestibular, mas também para universidade, porque o bom médico, ou o bom professor de história, como é que a química vai estar ajudando, não é a química, como aquele "besteirol" não, tão complicado se você for entender isso, até a gente que ensina química, pergunta para eles. $\mathrm{O}$ que isso que você ensina contribuiu alguma vez para vocês serem pessoas melhores no mundo? Não está claro isso. Então, a gente procura apertá-los um pouco por aí e aí o que acontece? Alguns que caiem fora, entendeu, e aí o que acontece com as interações deles. A maioria, começar a dizer, mas a culpa é de vocês mesmos, a culpa é da universidade. Quer dizer a culpa não é dele, então ele agora não vai salvar a pátria, mas aí tem um, dois, três, mesmo na licenciatura você vai fazer o papel e é ali que gente vai investir, esse grupo que está em formação, a gente vai contar bastante com essa sinergia entre eles. Então, tem um professor lá que vai dizer, não gente eu não vejo assim, se não tiver a gente vai ter que construir, se não tiver no grupo algum que topa rodar a roda do lado construtivo dessa reforma, não adianta, aí a gente vê se consegue, às vezes, a gente mesmo abandona ou eles acabam saindo do grupo, porque a nossa intencionalidade é a "ERR" claro que a gente não quer ela de modo imediatista não é, mas por exemplo, esse grupo que eu estou trabalhando já algum tempo, está longe, longe da gente normalizar a "ERR"mas, está muito longe do que eles trabalhavam a tempos atrás, entendeu? Nós somos um grupo e cada um tem o seu jeito, seu enfoque e processo.

Eu estava dizendo que cada um de nós na formação inicial ou continuada, temos uma intencionalidade que é comum que é agente planejar, desenvolver, construir um ensino com a "ERR", agora cada um de nós também tem as suas formas diferenciadas, cada um, se nós tivéssemos outros lá no mesmo ano, provavelmente criaria situações diferentes, mas em todos eles a gente tem esse algo comum, que é procurar, a gente estuda, mesmo que o professor é da rede, por isso que nós temos um objeto de pesquisa, acho que isso é uma coisa interessante. No "Grupo" nós temos alguns projetos de pesquisa e eles têm objetos de estudo das pesquisas de iniciação. Esses objetos de investigação foram identificados no coletivo, eu, por exemplo, tenho docente de doutorado E meu objeto de investigação é as interações do sujeito neste processo. O meu foco, mas eu sou tão interessada nesse objeto, como nos outros; não estou estudando especificamente interdisciplinaridade, ou a evolução conceitual, analiso as interações do sujeito, claro, não vou entrar em vários detalhes etapas, mas os diferentes objetos, diferentes projetos que eles têm foram definidos coletivamente e aí com esses grupos de pesquisa, e os projetos de pesquisa estão devolvidos no mesmo âmbito de pesquisa, então imagina, você tem essa pista, você vai usar na sua pesquisa, no nosso caso, tem uma disciplina da licenciatura, que os licenciandos estão filmando aquelas 
aulas, você sabe o que está acontecendo, não é nem o meu projeto que principalmente está podendo fazer a pesquisa com aquele material que está sendo produzido, mas todos do "Grupo" é envolvido nesse processo do registro, então são os registros que são feitos em áudio em vídeo a transcrição dos bolsistas participantes que têm iniciação científica, eles estão transcrevendo as fitas de vídeo em áudio e o material que foi transcrito é para todo mundo usar. Então, é bem assim, tenho lá esses órgãos de ensino, porque são recortados das transcrições, uma certa aula, enfim de seleção e um projeto pode esta analisando aqueles visões e um outro projeto pode estar analisando o mesmo, nós temos isso .

\section{V-São olhares diferentes.}

$\mathrm{P}_{8}$-Mas porque que pegou o mesmo de tantos que tem eu não sei porque pegou, mas se foi até porque ouviu um dia o outro projeto apresentado, eu posso usar ele para o meu, então, porque que não pode usar, porque nos somos um grupo. A gente procura trazer os resultados das pesquisas, então para nos realimentar com isso no grupo, mas eu ia dizendo alguma coisa que eu me esqueci, mas também não faz mal. Bom, eu não sei se as questões eram essas aí.

V-Eram essas, eu queria poder distinguir, quando você fala: olha isso aqui, esses trabalhos multidisciplinares, a escola vai fazendo isso, me parece que está claro esse conceito pra mim, quer dizer todo mundo pega um tema, no qual todos vão trabalhando, a interdisciplinaridade pressupõem um momento de planejamento maior.

$\mathrm{P}_{8^{-}}$- Planejamento e acompanhamento, veja bem, além do [planejamento o que a gente tem, durante a execução há vários encontros desses professores,] (14) das diversas áreas para contar, porque não é uma coisa linear, então a cada semana, sei lá a cada quinze dias o grupo se encontra para que haja relato, porque o professor de química continua dando aula de química, o de biologia e o de física e há momentos em que os três vão na sala de aula, [há momentos que os três vão na sala também, eles planejam algumas atividades, isso é meio dual, tem um momento que não é mais só física, só química, só biologia,] (15) por exemplo, eles vão fazer todo mundo tem um texto que é coletivamente pensado, que vai ajudar para todo mundo; então, você vai discutir sobre aquele texto e ele vão apresentar ao grupo, então todos os professores vão ter que estar lá nessa hora, tanto para mediar como para ouvir mesmo. E aí o que você ia dizer mais? E a avaliação também, as questões da prova, elas precisam ser questões especificas da química, mas também questões que transcendem, se não, ou seja, você faz um ensino interdisciplinar, mas a avaliação é só dentro da disciplina, a gente acha que ainda não houve a intencionalidade de se envolver algo que transcenda a disciplina, que pode ser até às vezes ligado a valores, atitudes, a postura, ao lado da produção deles, ao lado mesmo desse conhecimento, então, e a produção dos alunos muda bastante, porque como é vivencial, contextual, muitas disciplinas, muitas estratégias, muitos recursos e gente que muito que eles cresçam sempre, então, educação artística tem me ajudado, sempre entra contato com as empresas que produzem aqueles produtos, ai eles têm que fazer o relato disso. Então o eixo da pesquisa na formação, você está entendendo que tudo isso, visa criar na formação inicial, na formação continuada, nossa entende da escola, essa perspectiva, não é essa teoria sobre o que é a pesquisa na formação, mas é de desenvolver essa perspectiva e a gente faz isso com os alunos também. Nós temos estudo sistemático na metodologia, a gente leu aquele livro Pesquisação Integral e Sistêmica, do André Moran, não é o Edgar Morin, ele tem um livro, 
Pesquisação Integral e Sistêmica, gente todo o livro em cada quinze dias, então em cada encontro a gente planejava que nos próximos quinze dias qual era a dupla que vai ler a próxima parte pra ver uma sistematização em Power Point, tudo mundo vai ter lido, ter discutido, e também a gente lê algumas coisas, porque a gente está também, querendo se enxergar nisso, qual é o nosso modelo de pesquisa na formação nossa. A gente achou que não é exatamente, esse modelo, essa formação. Eu tenho trabalhado com a perspectiva de investigação ação química Carr e Kemmis, Contreras, João Melhas, o Nilbo também trabalha com investigação-ação, mas não é do grupo que trabalha com uma perspectiva ou outra no entendimento e desenvolvimento das pesquisas, como pesquisa mesmo e como pesquisa na nossa formação e junto aos alunos isso também comparece, então esse interdisciplinar, que é a sua grande questão, eu não respondi, mas ocorre, mas ela transcende.

V- Não, o que eu gostaria de saber é se na sua concepção, eu estou enxergando isso aqui é multi, aquilo é inter, a você diria isso é uma transdisciplinaridade é ou não é, ou eu acho que tem que avançar mais um pouquinho, ou não?

$\mathrm{P}_{8}-\mathrm{O}$ que eu percebo assim algumas situações tem professores que trabalham na universidade ou na escola ou mesmo licenciando que duma disciplina, vamos supor nós que somos da química, pelo fato de gente estar envolvido com o desenvolvimento de "ERR", a gente é demandado muito mais, certo a compreender com muita clareza, delimita com muita clareza o significado, porque você está trabalhando na relação com os colegas e lá tem os alunos da escola também, então o que eu percebo no interdisciplinar, uma demanda maior, muito maior, [do entendimento do uso adequado do conhecimento disciplinar, e por outro lado uma de certa abertura para se fazer algumas ampliações, algumas intersecções, algumas relações e aí o que a gente percebe que se com o nosso conhecimento a gente já conseguia compreender o principio transformador, aquela situação, enfim, falar, porque o que a gente quer com os conhecimentos é o que é falar com as pessoas no mundo sobre aquilo, viver melhor no mundo]. (16) Então, a gente percebe, eu percebo que hoje avancei nisso, que tenho muito mais jogo de cintura para dizer como é que é, que entendo, que compreendo, para usar as palavras no lugar mais adequado, você tem um cuidado maior, porque a gente está falando para pessoas que entendem o nosso conceito um pouco torto, e quando a gente está lá ouvindo a explicação do colega da física do porque que aquele ar, mas espere aí, deixe eu dizer uma coisa aqui, se você pensar isso que está ainda, isso ainda é química, talvez isso aqui te ajude a, e às vezes é o outro que diz espera aí, e as dúvidas que eles têm, certo e conseguem expressar nesse momento são de outro padrão de outro nível, então essa que é a riqueza, a gente perceber em alguma situação que gente, opa! Gente olha o que nós estamos discutindo aqui, alguns avanços nas compreensões das questões que se colocam elas transcendem a condição que poderia estar acontecendo se nós estivesse só ensinando a química, planejando, explicando, porque as perguntas que vêm da minha colega da física e as ajudas que ela me dá, ah tá! Então aqui, porque ela pensa mais do ponto de vista físico, a outra da biologia, espere aí, aqui a gente entende assim, a física está dizendo assim, como é que é isso, muitas vezes acontece essa situação e é ali que eu acho que é essa situação que é nova, que a gente está construindo, daí o porque eu sempre digo que até esta avaliação, espera-se que essa avaliação não fique só no disciplinar, porque aí vão dizer que nesse processo, já mesmo com os alunos será que a gente já consegue na licenciatura trazer à tona esse âmbito; então, o que a vê que nas avaliações, vê se coloca 
textos nas avaliações para os alunos lerem, responderem questões para frente, para vê se eles já pensam, também numa forma que transcende, só a definição do âmbito da água, não sei se eu consigo ser clara?

$\mathrm{V}-\mathrm{P}_{8}$, eu acho que deu para entender, desloca um pouco mais para o nível das discussões, indo um pouco mais do que eles estão familiarizados, não é isso?

$\mathrm{P}_{8}$-Exatamente.

V- Porque você tem outras contribuições de outros pontos de vista.

$\mathrm{P}_{8}$ - E nós teremos que buscar essencialmente essas condições entendeu? Porque ali elas extrapolam mesmo o diálogo que é disciplinar e a construção do aprendizado, quando você produz, um novo dialogo do mundo, mas em algumas situações se chegou a pensar que não é muito comum não de se estar se pensando naquele âmbito aquilo. Então, isso a gente está querendo pensar um pouco numa meta, numa meta aprendizagem, de se estar um pouco por cima daquilo que cada um está trazendo, a gente até já criou algumas expressões, mais isso a também faz, mas outra coisa que é assim, nem sempre planejamentos, as contradições conceituais que se busca elas avançam desde de o primeiro minuto, às vezes, elas tem que ter o primeiro estágio, bom, mas já tem aqui alguma interlocução, alguma inter-relação, já está um pouquinho interdisciplinar, pronto. Cada grupo às vezes, é muito motivado, na prática, está muito longe de se ter condições adequadas para que a gente faça um planejamento como a gente pensa conseguiu viver algumas vezes. Em geral, a gente sai até um pouco frustrada, mas é o que eu tenho dito sempre, não vamos querer ser imediatistas, não vamos querer soluções imediatas, o professor, também tem que ter certa segurança, ele não pode tratar de tudo.

V- É todo um processo, ele tem que ser preparado, até para se expor.

$\mathrm{P}_{8^{-}}$A gente tem assumido esse risco, quem sabe que daqui a alguns anos tenhamos muitas respostas, muitas questões, também.

V- Tomará, muito obrigado pela disposição. 
Entrevista: $\mathrm{P}_{9}$

Leciona (ou) na escola pública: 10 anos

Particular: 03 anos

Formação: Licenciatura em Química

Instituição: Escola de Ensino Superior de Mogi das Cruzes

Pós-graduação nível: mestrado

Início: 2004

Instituição: Universidade de São Paulo-USP

Data da entrevista: 21/03/2006

Tempo Total: $30 \mathrm{~min}$.

$\mathrm{V}^{44}$ - $\mathrm{P}_{9}$, você sabe que o meu trabalho tem sido no sentido de investigar a concepção de interdisciplinaridade dos Consultores dos Parâmetros Curriculares, mas nós queremos estender esse trabalho para professores do Ensino Médio e professores da Pós-Graduação. Um bate-papo que não comprometa, uma conversa. O que eu queria saber é quando você entrou em contato com a interdisciplinaridade, em que momento da sua vida você viu isso, quando você se deparou com essa questão? Se é que você se deparou um dia com isso.

$\mathrm{P}_{9}{ }^{45}$ - Sim, já me deparei, já fiz alguma discussão sobre o assunto, sobre a interdisciplinaridade, principalmente a discussão sobre a forma, ou métodos de como são feitas, as definições sobre multidisciplinaridade, transdisciplinaridade e tanto outros termos que são colocados aí.

V- Nessas discussões que você participou você já teria um conceito seu? Por exemplo, quando você pensa em interdisciplinaridade, muldisciplinaridade, transdisciplinaridade, você pensa eu tenho alguma coisa na minha cabeça que já estão concretizadas.

$\mathrm{P}_{9}$ - Eu tenho um entendimento formado, que está em evolução, digamos assim, mas neste momento eu acredito, na trans como [algo que é transversal a todas disciplinas, algo que transcendam as disciplinas,] (1) mas eu não sei explicar muito bem o que seria isso. Agora esse trans como se dá, ainda falta um pouco de leitura para mim. Para que eu possa defender categoricamente para você. Agora, a inter eu acredito mais na concepção de entender não como um determinado tema que as disciplinas vão estar desenvolvendo, Matemática faz isso, Biologia faz aquilo, não. É [um tema em que se faz necessário fazer a discussão do tema com conteúdos com diversas áreas e essas áreas seriam as disciplinas e essa conversa dessas disciplinas iriam fazer uma discussão sobre esse Tema, ou uma Situação Problema ou algo parecido.] (2)

V- As disciplinas seriam convidadas a fazer sobre esse problema.

$\mathrm{P}_{9^{-}}$Isso, seria a explicação, ou o entendimento para a situação colocada, pro tema colocado. Pode ser o professor, estar desenvolvendo isso, [agora eu entendo que o professor não irá conseguir sanar tudo isso, e que ele não tenha todas as informações.] (3) Aí seria interessante o professor explorar outras fontes, explorar outros meios, [teria os

\footnotetext{
${ }^{44}$ Refere-se ao entrevistador: Valdir Pedro Berti

${ }^{45}$ Refere-se ao entrevistado: $\mathrm{P}_{7}$
} 
especialistas, as revistas,] (4) não propriamente ele explorar tudo isso, [mas induzir o aluno a procurar isso, propiciar com que o aluno desenvolva isso.] (5) Procurar outras informações, mas aí também, obviamente colocar a parte dele, a falar a parte dele, já estar colocando, colaborando, contribuindo até um certo ponto, porque ele não vai deter todos os conteúdos disciplinares, né? Então, [em determinados momentos que ele vai ter que pedir para os especialistas ajudarem,] (6) e muito importante que ele consiga ter discernimento e consiga colocar isso, propor isso e que os alunos façam isso.

V- Deixe-me ver seu entendi está pensando, assim, a princípio o professor começaria, e depois ele estenderia até um certo momento explorando esses assuntos ou entrando nos conteúdos de outras disciplinas, mas irá chegar em um determinado momento que ele não tem domínio de uma dada disciplina aí ele convidaria os outros professores a participarem ou ele já começaria com os professores, como que é?

$\mathrm{P}_{9}$ - [O interessante é que ele começasse a discussão já com os professores,] (7) mas como a gente coloca assim, para o professor iniciar é que já está muito intrínseco uma vivência de escola pública, pois infelizmente o que acontece, normalmente na escola pública é que um, ou dois professores começam desenvolver um trabalho e os outros acabam comprando a idéia. Então, eu acho que falo muito mais da vivência disso, e não propriamente do que eu acho que seria mais importante. Acho que deveria começar com professores mesmo.

V- Entendi, mas na escola pública pode começar com um professor e outros de repente podem falar: você está fazendo um trabalho interessante, que legal, e em determinado momento participar do trabalho.

$\mathrm{P}_{9^{-}} \mathrm{E}$ [além de professores mesmos, falar pro técnico em eletricidade, sobre determinadas coisas, ouvir o outro lado do conhecimento.] (8)

\section{V- Palestras?}

$\mathrm{P}_{9}$ - Exatamente, visitação, é que demanda tanta energia do professor, tanta situação, que provavelmente o professor não faça isso não tende a fazê-lo, ou [não caminham pra isso, por que? Porque não consegue, não tem condições, não são dadas as condições para os professores, os que tem iniciativa de começarem.] (9)

V- Você acha assim, o trabalho é interessante, mas no sistema em que o professor está inserido, ele não tem condições, mesmo tendo, por exemplo, [Horas de Atividades Pedagógicas (HTPCs), ] (10) seria pouco, é isso?

$\mathrm{P}_{9}$ - A estrutura em si que é colocada para o professor, acho que não é a estrutura propriamente, algo mais da questão de estratégia mesmo, de envolver, de possibilitar ao professor uma porção de estratégias, e o HTPC, infelizmente é pouco utilizado para isso.

V- Os professores não otimizam esse espaço. 
$\mathrm{P}_{9-}$ [Eu estou falando pra você por dois motivos, um é a experiência das escolas que lecionei, em que o HTPC era muito, a discussão sobre isso era escassa, e também o pouco material que eu tenho lido que falam das concepções dos professores sobre interdisciplinaridade] (11) apontam [que quando discutem esse momento de discussão e reflexão que seria o HTPC que isso, também, é muito pouco tempo. Definitivamente isso não acontece, então é por isso que eu comento isso pra você, mas eu acho que o mais forte é a minha vivência de dez anos de HTPC que eram pífios, nesse sentido.] (12)

V- Entendi, não na questão de tempo e sim de pulso.

$\mathrm{P}_{9}$ - Exatamente, acho que a proposta do HTPC é muito interessante.

V- Para fazer essa proposta interdisciplinar, o professor, primeiro ele teria que sentar junto, discutir isso no momento prévio, para depois ir para aula ou você acha como isso se daria?

$\mathrm{P}_{9^{-}} \mathrm{A}$ discussão, ela deve ser constante, antes e depois, discutir no momento de planejar, fazer essa discussão, [discutir a parte conceitual e epistemológica da interdisciplinaridade, ou para o campo filosófico da questão da interdisciplinaridade, fazer toda essa discussão, se munir para entender isso, para depois construir um material,] (13) dentro da discussão que foi feita, para estar trabalhando, desenvolver com o aluno e depois disso eles tentarem, discutirem novamente, então é uma auto-reflexão.

V- Das suas experiências que você trabalhou nesses anos, você citaria uma em que você acha que foi um trabalho interdisciplinar? Foi ou não foi?

$\mathrm{P}_{9^{-}}$Não me lembro de nenhum trabalho que tenha contemplado a interdisciplinaridade na escola pública que eu trabalhei. Já me deparei com discussões sobre interdisciplinaridade, mais uma discussão acadêmica de texto, de material, sugeridos por grupos de pesquisa.

V- Na escola particular?

$\mathrm{P}_{9}$ - Na escola particular menos ainda (risos!).

V- Nem em discussões nas HTPCs você ouviu falar disso, onde os professores falem sobre os parâmetros, não ouve nada? Ou os professores comentam isso como um slogan, falam da interdisciplinaridade como falam do professor construtivista, como isso se dá?

$\mathrm{P}_{9}$ - Nós professores devemos estudar os materiais acadêmicos, e procurar entender, refletir e até que ponto o material pode ser incorporar dentro da realidade de trabalho. Nós professores temos que essa discussão, se a gente cai naquela coisa do senso comum, que ouvi dizer aqui e ali, interdisciplinaridade é isso. Eu me lembro de um projeto que foi desenvolvido numa escola que eu trabalhei, que era o projeto Copa do Mundo, tal professor falava disso, tal professor falava daquilo, e aí todo mundo achou que estava contemplando a interdisciplinaridade e na verdade não estava, quer dizer faltava muita coisa ainda para contemplar. 
V- Essas coisas seriam as discussões de um tema, ou os professores sentando e discutindo sobre aquilo, como eles iriam abordar? Ou o que seria?

$\mathrm{P}_{9}$ - Não, não, não houve essa discussão, não ouve essa discussão depois , não houve uma discussão sobre o tema específico, o que especificamente a partir dali, que conhecimentos eram necessários para se fazer o entendimento do tema, não houve nada disso. [Acho que primeiro passo para você contemplar a interdisciplinaridade é você fazer uma discussão dentro de um determinado tema, de que conteúdos, ou de que conceitos científicos vai estar se munindo pra poder entender esse tema.] (14)

V- Você classificaria essa tentativa de trabalho como, na sua cabeça, o que seria isso? Um trabalho inter, multi, ou uma tentativa de interdisciplinaridade?

$\mathrm{P}_{9}$ - Essa proposta foi obviamente uma tentativa de interdisciplinaridade, e muitos professores acreditavam que trabalharam com a inter.

V- E você acha que se chegou no máximo a quê?

$\mathrm{P}_{9-}$ [Numa mult, né? Aquela coisa que é mais pontuável das disciplinas.] (15) Muito embora tenha acontecido todos esses problemas, foi um trabalho, foi um trabalho muito interessante, onde os professores ficaram muito motivados, porque ele viu boa parte dos alunos muito motivados também, então acho que no fator afetivo e emocional foi muito bom, no fator de entender, aí eu acho que falta muito.

V- Falta um estudo mais profundo?

$\mathrm{P}_{9}$ - Falta, falta, tornar o HTPC um grande fórum de discussão pedagógico mesmo.

V- Penso, que a idéia era essa, mas na prática não se concretizou.

P9- O Saber ensinável e o saber como ensinar.

V- Nesse trabalho que foi uma tentativa, qual disciplina que puxou isso?

$\mathrm{P}_{9}$ - História, na época eu não tinha muita leitura para poder entrar com a química, para poder contribuir, dentro do contexto da química e o tema não ajudava, mas também pelo fato que você queria aproveitar uma situação de momento que era a Copa do Mundo na época. Então se houvesse uma discussão sobre a inter o tema não teria sido esse, obvio né?

V- Será que houve alguma disciplina que aderiu, ou ele fez sozinho e no final ele falou, foi interessante, os alunos ficaram muito motivados?

$\mathrm{P}_{9}$ - Ela alavancou e quase todas as disciplinas aderiram.

V- Mas todos separados, cada na sua? 
$\mathrm{P}_{9}$ - É, vamos trabalhar comida típica, os aspectos econômicos dos quatro países do grupo envolvido, acho que esse trabalho foi interessante, nesse sentido.

V- O que aconteceu foi mais ou menos assim, puxa-se o projeto, aí você da química percebe que pode trabalhar dessa forma, o da geografia daquela, mas ninguém se sentou para estudar isso antes, definir o que poderia ser interessante, definir o que é interdisciplinaridade, tentar entender esse processo, isso não houve?

$\mathrm{P}_{9}$ - [Houve uma tentativa, eu e uma outra colega tentamos fazer essa discussão, ela se iniciou, mas ela se perdeu, e se perde com assuntos corriqueiros da escola.] (16) Assuntos, como, tal aluno se envolveu, ou não se envolveu, [e que acabam desviando o foco da discussão.] (17) E você vai para outras coisas que não contribuem. Os próprios professores que chegavam atrasados.

V- Hoje, a reflexão que você faz disso, você acha a interdisciplinaridade uma proposta viável, não é viável, dá para se trabalhar o conteúdo não dá, o que você acha?

$\mathrm{P}_{9^{-}}$[É uma proposta viável,] (18) eu acredito, ela é muito importante para trabalhar oconteúdo; é o caminho, [a educação não pode continuar com um saber escolar diferentedo cotidiano, com todo o aspecto do cotidiano.] (19)

V- Você acha que a interdisciplinaridade é capaz de fazer essas ligações, entre o mundo do saber sistematicamente elaborado e o do senso comum?

$\mathrm{P}_{9}$ - Exatamente [a interdisciplinaridade consegue fazer essa transposição didática, para fazer uma leitura do mundo.] (20)

V- Agora, você como aluno da pós-graduação, com uma experiência de dez na escola pública, conhecedor dessa realidade, um professor com a "mão na massa" que conhece os entraves. Olhando para a escola pública, com todas as limitações que ela tem e não são poucas, professores como numero excessivo de aulas, tendo que dar aulas em várias unidades e por aí afora. Se houvesse uma equipe gestora que abraçasse a causa da interdisciplinaridade, ela é realmente possível de ser realizada?

$\mathrm{P}_{9}$ - Essa é uma questão muito difícil de responder, Valdir, muito difícil!

V- Eu creio que sim, mas gostaria de ouvir a sua opinião.

$\mathrm{P}_{9}$ - Acreditar que a proposta é importante, é viável, é necessária, sim; porém neste momento, quando eu lanço um olhar na escola pública, e eu posso falar isso de carteirinha, [das dificuldades e os problemas que a equipe gestora tem que lidar, com que tem lidar, as ações eu acho que o pedagógico fica muito a desejar,] (21) mesmo que aquele diretor tenha uma vivência, tenha noções do entendimento pedagógico, fica muito a desejar, [infelizmente, vai de ter demandar muita energia para que os professores compreendam a proposta, muita energia para não se perder em questões burocráticas, administrativas; porque a proposta parece fácil mas não é tão fácil de realizada não.] (22) Não estou dizendo na teoria é uma coisa e na prática é outra, não é esse o discurso. A teoria é importante, 
porque a gente discute a teoria e vamos exercitar na prática e quando a gente faz uma reflexão dessa teoria na nossa prática, a gente trabalha esses elementos e verifica até que ponto eles são viáveis ou não, e hoje a interdisciplinaridade da forma como muitas escolas estão, não adianta.

V- O que você quer dizer com isso?

$\mathrm{P}_{9-}$ - [a equipe gestora se preocupando com a parte administrativa, a discussão nas HTPCs não são feitas nesse sentido;] (23) então como está sendo feito, não é, possível. E mesmo que algumas escolas já estejam caminhando nesse sentido, não é um trabalho de um ano ou dois, mas uma trabalho que vem a tempo. Então é algo possível, necessário tem que ser feito, acho que Letra e Vida é um projeto que aponta nessa direção. [Acho que a interdisciplinaridade hoje não é inviável para produzir conhecimento, ela é inviável para ter espaços, do ponto de vista estratégico.] (24) você.

$\mathrm{V}$ - $\mathrm{P}_{9}$, quero agradecê-lo pela disponibilidade, foi um grande prazer conversar com 
Entrevista: $\mathrm{P}_{10}$

Leciona (ou) na escola pública: Não

Particular: 08 anos

Formação: Bacharel em Química

Instituição: Universidade Mackenzie

Período: 1987-1990

Formação: Pedagogia - Administração Escolar - Universidade de São Paulo

Período: 1992- 995

Pós-graduação nível: mestrado

Início: 2003

Instituição: Universidade de São Paulo-USP

Data: 22/06/2006

Tempo Total: $42 \mathrm{~min}$.

$\mathrm{V}^{46}-\mathrm{P}_{10}$, eu vou contar um pouco da história, da nossa história, acho que já comentei com você em outras oportunidades, mas o que a gente pretende fazer é conhecer a concepção de interdisciplinaridade, para isso eu já conversei alguns consultores, as pessoas que estão envolvidas diretamente com a elaboração dos parâmetros. E aí a gente pensou em fazer, também uma revisão pela literatura sobre esse conceito, ouvir alguns professores da Diretoria de Ensino que participaram com propostas com projetos interdisciplinares. Aí nós achamos interessante ouvir alguns pós-graduandos, não os novos, porque a gente acha que não haverá muita mudança nas suas concepções, mas ouvir o pessoal que estão a mais tempo; então, o que a gente quer saber é o seguinte, se alguma vez na vida você se deparou com essa questão da interdisciplinaridade, como foi, como isso se deu, ou você nunca ouviu falar sobre isso, entendeu? Conta um pouco da sua história.

$\mathrm{P}_{10}{ }^{47}$ - Bom, eu sou química e formada pela universidade markenzie que é particular, sou formada,[quando eu fiz a licenciatura não se falava absolutamente em interdisciplinaridade,] (1) sou a típica professora que fez a licenciatura, porque estava na grade, mas eu não ia ser professora de jeito nenhum, trabalhei em indústria durante a universidade, no segundo, terceiro e quarto ano, mas um ano eu fui dar aula à noite, então eu sou aquela professora que foi dar umas aulinhas à noite, enquanto trabalhava o dia todo. E dei aula e achei que era aquilo que queria fazer só que eu não sabia, eu tinha vinte anos, eu deixei a Rodhia Farmacêutica, prestei o vestibular e entrei aqui na USP na pedagogia e fiz cinco anos de pedagogia e quatro de administração escolar.

V- Isso é raro, uma pessoa sair das exatas e ir para a educação, realmente me parece aquele caso de paixão mesmo, né?

$\mathrm{P}_{10^{-}}$É, quando sai da indústria e fui pra dar aula, foi com um supletivo à noite, e trabalha numa escola pública de manhã e fazia pedagogia à tarde, eu deixei no outro ano o supletivo e trabalhei em duas escolas públicas, numa delas aqui em São Paulo que tinha o Projeto Experimental da Lapa e foi no Experimental da Lapa que a minha vida mudou (risos!) daí pra frente. Então, no experimental eu trabalhava com ciências, eu dava aula de química e eles usavam livros completamente diferentes, então não era aquela estrutura tradicional, não era interdisciplinar, mas ele não era conteudista, ele tinha uma outra

\footnotetext{
${ }^{46}$ Refere-se ao entrevistador: Valdir Pedro Berti

${ }^{47}$ Refere-se ao entrevistador: $\mathrm{P}_{8}$
} 
concepção. Eu não subi lidar com a questão da disciplina, nessa escola eu saí de lá. Quando eu sai de lá eu fui pro outro colégio católico, colégio Notre Dame aqui no Sumaré, essa escola de freiras, que seguiam a teologia da libertação. A coordenadora era da PUC do grupo da Ivani Fazenda, ela já havia trabalhado na prefeitura de São Paulo e a coisa lá era toda diferente, só que era um lugar de formação, então a C.T. trabalhava muito e a própria coordenadora, que agora coordena outros lugares, enfim que era professora da PUC. A primeira experiência que tenho com a interdisciplinaridade, que se olhando hoje eu não sei se foi inter mesmo, mas que a gente não trabalhou no conceito de interdisciplinaridade, foi um projeto com uma oitava série que eram aulas de química, então nós tínhamos dividido química e física, eu não sei se você se lembra daquele projeto da foto na lata, que você pegar uma caixa, então todos os professores se reuniram pra fazer um projeto que era esse foto na lata, então estava super claro para o grupo, isso faz tempo viu, deve ter sido em torno de noventa e oito, talvez; então era um grupo que estava muito avançado.

\section{V- Em todas as disciplinas?}

$\mathrm{P}_{10^{-}}$Deixa eu me lembrar, mas eu acho que era todo mundo, então que nós fizemos, foi um projeto que teve um produto final muito interessante. $O$ mote, não era tirar a foto na lata, uma lata de Nescau que você reveste com um papel preto e depois faz um furinho e reveste com papel fotográfico abre e põe o diafragma pra aquela foto e aí faz a revelação; então o mote era trabalhar com a tecnologia, mas assim, que as crianças pudessem compreender, como é que uma máquina fotográfica funciona, e pra isso ela iria passar por todo esse processo. As fotos da lata, não ficam muito boas, mas aí a professora de Artes trabalhou, então ela pegou aquelas fotos das latas, colocou cartazes e as crianças desenharam aquilo que elas tinham fotografado, tinha ensino religioso nesta escola e professora, a partir da questão da fotografia uma sala de olhos, então as crianças cortaram e fotografaram olhos colaram na sala inteira e vieram coisas quase assustadoras, você entrar numa sala em que tudo estava te olhando, o professor de Matemática trabalhou na questão da proporção nas fotos, o professor de Física foi o que levou eles para o pátio e nós fizemos o laboratório de revelação na escola. E aí tem aquela coisa da sala ser escura da sala ser vermelha tem uma concepção de ciências aí por trás. Foi a primeira vez que eu soube fazer um diário de bordo que eu guardei por um tempo e depois eu emprestei para uma pessoa e deve estar servindo para alguém que nós registramos desde do primeiro dia, com as crianças até o final que foi uma exposição grande.

$\mathrm{V}$ - De todo o processo.

$\mathrm{P}_{10^{-}}$De todo o processo, o registro pro trabalho interdisciplinar é super importante, né?

V-Sim, acho que em todos, mas principalmente nesse tipo de trabalho.

$\mathrm{P}_{10^{-}} \mathrm{O}$ trabalho é mais pra ele, pra você poder voltar a avaliar depois, né?

$\mathrm{V}$ - Tanto o professor e o aluno faziam, ou como que era? 
$\mathrm{P}_{10^{-}}$Não, não tivemos um por sala no projeto, então nós íamos colocando os registros do que estava acontecendo. Esse talvez tenha sido em escola o melhor projeto, eu não sei se foi o melhor, porque como ele foi a primeira coisa que eu vi e que nós colocamos como objetivo e chegamos até o final. A professora de Artes, ainda no meio de uma exposição, no meio do trabalho, visitou com eles exposições para eles olharem pra eles olharem essa coisa da fotografia, e uma das preocupações eram será que eles não vão enjoar da gente falar tanto em fotografia, mas não aconteceu, porque estava tudo muito diferente $\mathrm{e}$ foi assim, durou uns meses (um mês e meio), nós começamos e chegamos na exposição.

V- Mais ou menos o tempo que um projeto deve durar.

$\mathrm{P}_{10}$ - É, bem interessante.

V- Mas você acha que mesmo falando o tempo todo de foto e o aluno não enjoou foi, porque as disciplinas trabalhavam, mesmo tendo o mote da fotografia, trabalhavam o conteúdo de forma diferente, é isso?

$\mathrm{P}_{10^{-}}$De forma diferente, é por isso, eu acho e tem outra coisa que às vezes eu acho que acontece é que tem ser interdisciplinar a qualquer custo, tudo, né? Então as escolas, ou a prefeitura, chega e fala, todo mundo vai trabalhar com violência, e aí você se inventa coisas; ali era um grupo maduro que fez uma proposta e quem não entrou eu acho que foi Educação Física não tenha participado, mas História participou, então teve a história da fotografia, o professor de Geografia trabalhava com fotos de satélites nesta escola, eu nunca vi outra escola que trabalhasse com isso, então ele trouxe, ele era aqui da USP, ele levou fotos de satélite, as crianças desenharam em cima, foi projeto muito bacana, pra mim foi a experiência marcante de começo de um trabalho, foi um resultado muito interessante mesmo. A nossa escola tem uma forma de fazer esse trabalho, mas eu nunca vi, quando eu penso neste trabalho, eu acho que foi uma pena, a gente não publicou.

V- A propósito sobre esse mote que vocês tinham, mas como vocês se comunicavam sobre isso?

$\mathrm{P}_{10^{-}}$A escola tinha [uma reunião de equipe por semana com todos os professores (2) juntos, mais uma reunião por área. Então, era uma reunião com todo mundo, uma vez por semana, o que dá bem para acompanhar e a coordenadora se reunia um dia com os professores de química, outro com os de física, outro com o de história durante a semana]. Esta escola proporcionava esse tipo de trabalho.

V- Ela tinha estrutura para isso.

$\mathrm{P}_{10^{-}}$Tinha estrutura e um currículo que permitia, não era só uma preocupação com o conteúdo engessado, o livro didático, e a preocupação estava mais nos objetivos. Então, essa avaliação por objetivos, ficava mais fácil pro grupo só que dava trabalho, né? Dá muito trabalho. Quando eu saí dessa escola, eu fui pro colégio Makenzie que tem uma super estrutura, mas o que se faz é pegar o livro. 


\section{V- É uma formação mais para o vestibular.}

$\mathrm{P}_{10^{-}}$Completamente focada para esse fim, inclusive quando eu cheguei nesta escola, eles tinham saído em que eu brinco que é construtivismo à telefone sem fio, sabe? Alguém leu o Piaget e foi contando pro outros, quando eu cheguei eles não queriam falar de projetos, nem de construtivismo, nem de interdisciplinaridade, nada; dentro do Makenzie eu tive oportunidade de ser professora da universidade, como eu tenho formação de química e pedagogia eu fui trabalhar em prática de ensino de química especificamente eu fui professora de uma disciplina que eu acho que só tem no Makenzie que se chama de Trabalho Pedagógico Interdisciplinar eu fiquei quatro trimestre nesta disciplina, eu tive quatro turmas e três professoras, então nós juntávamos os alunos da licenciatura de química, física, de matemática e de filosofia, de português, inglês e eventualmente algum aluno de francês e biologia; então todos alunos se juntavam em quatro turmas, cento e cinqüenta alunos aproximadamente e nós fazíamos uma simulação do que seria em grupo de professores de uma escola, trabalhando um projeto interdisciplinar, ou seja, faz de conta que vocês são professores de uma escola e vão fazer um projeto interdisciplinar. Esse trabalho a gente publicou, esse trabalho a gente foi pra UNESP, para Congresso, então, cada grupo e aí os grupos eram diferentes, ah tinha psicologia, também, então um psicólogo, um químico, um físico, e aí um trabalho que o grupo quisesse compor, obrigatoriamente deveria ser um estudo do meio, e nós fazíamos com esses alunos um estudo do meio, com todos os problemas que eles poderiam ter; só que era uma disciplina caótica, porque você imagina, a mesma disciplina dada por três, às vezes, quatro professoras juntas, com muita gente, dividida às vezes em duas ou três salas e aí você teria que orientar todos os grupos; então nós fazíamos três encontros de fundamentação teórica, o estudo do meio e depois as discussões. Na fundamentação teórica começava toda a briga nossa né? Entre as professoras, porque o que é interdisciplinaridade, afinal? (risos) Então, nós trabalhávamos com um texto da Ivani Fazenda, com o do Vasconcelos e mais alguma coisa de didática, de determinação de objetivos, nada muito fechado, o que mais me incomodou no curso foi, que me fez deixar era mesmo a falta de acordo com as minhas colegas, porque chegou uma hora que ficou insustentável, porque as diferenças metodologias, entre nós ficou tão grande, quanto a exigência do projeto que os alunos deveriam apresentar, que aí se desmontou e outras pessoas vieram e tomaram o lugar, mas uma das professora que mais abraçava essa história da interdisciplinaridade, achava que a interdisciplinaridade é atitude; então a Ivanir Fazenda era que estava lá no curso, né?, a fundamentação teórica e era sempre assim, trabalhava-se com essa questão da humildade, em que a sua disciplina não era mais importante do que a do outro e tentar fazer uma colcha de retalhos, em que todo mundo pudesse de alguma forma trabalhar com projeto, esses projetos também tinham que ter um produto final único, então, por exemplo, eles poderiam propor um livro, uma peça de teatro, um jornal para a comunidade, uma feira de ciências, foi uma super experiência, mas essas aulas eram aos sábados, e nós saímos, assim, você precisava ir pra casa e dormir duas horas para se refazer daquilo.

\section{V- Tamanho era o desgaste.}

$\mathrm{P}_{10^{-}}$Isso, primeiro porque os alunos, eles só tinham aquele horário para se encontrar, igualzinho o professor na escola, e eles não sabiam lidar direito com isso, e eles tinham autonomia para decidir muitas coisas, nós votávamos qual ia ser o local da 
visitação, para o estudo do meio e daí cada uma iria fazer uma proposta; então, nós fomos para o Parque do Ibirapuera, pro Museu do Ipiranga, pro Dops que é aqui no centro e pro Parque da Água Branca, então começa a parti da aí, pra onde é que nós vamos pro estudo do meio? Então, o aluno quer ir pra favela, pois os licenciandos falam isso, se eles fossem professores, se eu fosse professor eu gostaria de levar os alunos pra favela, pra eles conhecerem. Minha posição é assim, se eu for levar pra favela, é melhor levar pro zoológico, vai aproveitar mais e não vai mostrar o outro, então eles tinham a liberdade de propor o local, e nós chegávamos num consenso com uma certa facilidade e aí dentro grupo pequeno, qual escola, eles fariam dentro do imaginário, o objetivo geral, o objetivo específico de cada disciplina, como cada disciplina iria trabalhar dentro daquele projeto, com tudo, então desde de recurso, a metodologia, o planejamento o que ele iria fazer na aula um, aula dois, aula três, e como eles fazer o produto final; então dava muito trabalho pra eles, era um trabalho de formação da licenciatura, saia coisa muito ruins, mas saíram coisas maravilhosas em então, essa disciplina tem no Makenzie ela continua.

V- Acho interessante que ela permitia ao professor simular a prática dele, de planejamento, de objetivos.

$\mathrm{P}_{10^{-}}$A prática dele, eu até acabei de ler recentemente um artigo que falava de disciplina integradora, essa era uma disciplina integradora, né?

V- E a avaliação, você chegavam a discutir a essa questão, ou não?

$\mathrm{P}_{10^{-}}$Chegávamos, então os que eles falavam, que eles tinham o discurso da avaliação contínua e eles fariam a avaliação do processo, isso era uma exigência nossa.

V- Disciplinar, ou entre os professores?

$\mathrm{P}_{10^{-}}$Os professores, eles muitas vezes propunham que cada um tivesse uma nota $\mathrm{e}$ uma nota como produto final, o que fizesse do grupo entre os alunos deles, e que eles fizessem uma avaliação, continuamente, então, fez as atividades, cumprem os prazos; enfim, no final, esses licenciandos faziam uma auto-avaliação, mas se eles fossem lá com o grupo, porque a confusão que isso dava era uma coisa impressionante, No ultimo dia nós juntávamos os cento e cinqüenta, cento e sessenta, quase todos, e cada grupo tinha um tempo curtinho para contar pro outros o seu projeto, porque nós tínhamos em torno de dezoito trabalhos diferentes, saindo do mesmo estudo do meio; então tinha muita coisa gratificante, quando tinha grupos que iam se apresentar e falavam lá na minha escola, como se a escola existisse mesmo, né. E nós tivemos grupos falando desde tema transversal, pra sobre saúde, até gente falando sobre madeira, como essa madeira saia; enfim vários assuntos. Essa foi a escola, onde eu cheguei mais perto da interdisciplinaridade e a minha ultima experiência no ano passado, em que eu orientadora pedagógica no colégio no Makenzie, e aí assim, por conta de um trabalho que eu escrevi em dois mil que escrevi no curso do Luís Carlos Menezes, ciência linguagem eu fiz um trabalho sobre a radioatividade; então esse era trabalho em se discutia a ética na radioatividade, né, essa era a minha proposta, a professora de química, a professora do Makenzie no ano passado, fez um trabalho de pesquisa, mas não chegou a ser um trabalho interdisciplinar, mas pra aquela estrutura super rígida foi um avanço absurdo, foi um trabalho com a professora de química, 
história, física ética e cidadania.

V- Porque você diz que não foi um trabalho interdisciplinar?

$\mathrm{P}_{10^{-}}$[Porque, ele foi estanque, então historia discutiu aspectos históricos, mas não houve uma, eles falam uma integração, né, mas não teve comunicação.] (3)

V- Você quer dizer planejamento em grupo, eles não conversavam?

$\mathrm{P}_{10^{-}}$É, e não houve um produto final que partisse dessa discussão. O que a professora fez, os alunos fizeram um a pesquisa na informática sobre a radioatividade e aí ela dividiu os grupos, dois falaram da historia da radioatividade, dois grupos da arte, como a arte foi influência da por isso, Salvador Dali, Vinícios de Morais.

V- Rosa de Hiroshima.

$\mathrm{P}_{10^{-}}$Tem uma que se chama bomba atômica, o professor de física trabalhou especificamente com as equações de decaimento, mas cada um dentro da sala trabalhou uma coisa e apresentou para a professora, eu falei que não foi inter, mas professora falava que era um trabalho interdisciplinar, pra mim Valdir [todo o problema da interdisciplinaridade está no conceito, quando eu volto lá na Ivani Fazenda a interdisciplinaridade é uma atitude isso pra mim é pouco,] (4) pra consegui definir, agora se este trabalho foi interdisciplinar, não foi, ele foi um trabalho ótimo, os meninos conseguiram talvez, esse era o nosso objetivo, verificar que aquilo que aconteceu no final da Segunda Guerra, então que um país ter jogado uma bomba em outro, que aquilo é um fato isolado, que existe uma concepção de ciência por trás disso, que existe uma concepção histórica, que a arte foi afetada, o mundo foi afetado por aquilo e que existe a ética na ciência, era isso que eles deveriam saber. Agora, esse sinal, como a ética, o aluno tem sozinho.

V- Ou seja, [se houve essa integração, esta foi feita pelo aluno.] (5)

$\mathrm{P}_{10^{-}}$Exatamente, pelo aluno lá dentro dele.

V- Então, ele foi interdisciplinar do ponto de vista do aluno. Me parece que para os professores não foi algo interdisciplinar, [mas para os alunos tiveram uma idéia de integração de tudo isso. ] (6)

$\mathrm{P}_{10^{-}}$Agora, eu tenho dúvida se um aluno sozinho consegue fazer isso.

V- Essa é a dúvida que persiste, se o professor não atuar aí, nessa zona, se aluno terá essa capacidade.

$\mathrm{P}_{10}$-Eu acho que essa intervenção, ela tem que ser pontual, então o professor não pode deixar pra ver se aluno conseguiu, ele tem que ir lá e verificar, se ele entendeu, se ele viu, depois de todos eles apresentarem uns para os outros, faltou um final pra isso. [Agora, 
vamos fazer um final pra isso, vamos fazer um texto, mesmo que fosse um texto coletivo, talvez eles mostrassem toda essa inter-relação.] (7)

V- Isso não foi feito?

$\mathrm{P}_{10^{-}}$Não, não foi feito.

V- Quer dizer no final o professor terminou, não houve produto final, no mínimo o professor avaliou o conteúdo de química, de física, quer dizer a estratégia foi interessante, mas no final volta-se a forma tradicional; mas diga uma coisa, o que os alunos acharam do projeto?

$\mathrm{P}_{10^{-}}$Eles gostaram, eles acharam muito interessante e que nunca foi feito nada parecido. Falar pra eles da arte, ou mesmo quando foi solicitado que eles procurassem heróis de histórias em quadrinhos, onde aparece o conceito científico de radioatividade, $\mathrm{O}$ Hulk, o Homem-Aranha, o alcance dos conceitos de ciência. Em última análise isso interfere no conceito de ciências que o sujeito tem.

V- E do ponto de vista dos professores, eles acharam motivador, ou não?

$\mathrm{P}_{10^{-}} \mathrm{O}$ professor de física achou que ele ficou pra trás, porque o dele era mais chato, como ele trabalhou especificamente com as equações, ele achou que os alunos não se interessaram muito por aquilo. A professora de história adorou né, porque foi muito interessante essa fase da Segunda Guerra se você pegar isso do ponto de vista históricocientífico e a professora de ética também, tem ponto bom e o mau, tem direito, não tem?

V- Esses tipos de projetos continuam ou não?

$\mathrm{P}_{10^{-}}$Hoje acabou, parou.

V- Então, vocês avaliavam por objetivos, o portfólio deles, a produção final, é isso?

$\mathrm{P}_{10^{-}}$Isso, mesmo.

V- Mas a avaliação não era produzida entre os professores.

$\mathrm{P}_{10^{-}}$Não, não uma avaliação pra todos não.

V- Mas se levava em consideração o que o aluno produziu.

$\mathrm{V}$ - $\mathrm{P}_{10}$ e do ponto de vista da disciplina, os alunos aprendem, ou não aprendem, esse tipo de trabalho ajudava, ou não ajudava. O que você acha?

$\mathrm{P}_{10^{-}}$Aprendem, aprendem, como um currículo disciplinar, currículo brasileiro disciplinar, a gente pode amar ou odiar, mas o fato é que ele é disciplinar, e aí entra aquela questão o que a gente faz com isso. Dentro disso dá pra você mostrar que o mundo é interdisciplinar, você aprende a digestão, porque a digestão é um fenômeno biológico, você 
mastigar ele é físico, você engole e uma parte é física e outra é química, enfim, o que ele é, o que mais importante discutir o que ele é, ou compreender o processo como um todo, mas eu acho que aprende sim, ele aprende mais, ele aprende a química, aprende a física, aprende a história.

V- As relações entre elas, ou seja, o objeto de estudo e suas relações.

$\mathrm{P}_{10^{-}}$Então, se olha a Segunda Guerra, se você olha a fotografia, então na Segunda Guerra, então ele vê os cientistas, o prêmio nobel de química, física, existe uma ciência boa ou ruim, o avanço da ciência pela guerra ele vê isso, e ele vê a história da Segunda Guerra, que aconteceu no Estados Unidos, no Japão ou na Itália, e ele pode dizer o que aconteceu no Brasil? Porque, não é um fenômeno único, ter acontecido uma guerra mundial, não é um fenômeno só da história, é de todos.

$\mathrm{V}$ - E isso de trabalhar esses projetos era uma proposta da escola, ou você foi para o Makenzie foi uma proposta sua?

$\mathrm{P}_{10^{-}} \mathrm{O}$ que aconteceu foi o seguinte, eu tinha escrito esse artigo em dois mil, porque o grupo anterior publicou em almanaque pela Vozes o que foi feito nesta disciplina. Eu escrevi o artigo ele acabou se perdendo, porque ele iria sair como segundo volume, ou escreveria até diferente, mas foi nessa época que eu tinha entrado no Makenzie, eu professora de química junto com outros colegas que eram da escola pública (da prefeitura) ela sabia desse trabalho e ela se interessou, mas demorou, porque era assim, nunca dava certo, mudavam de série, não se ensina mais radioatividade, não precisa ensinar radioatividade porque não cai no vestibular, e o tempo foi passando, nunca dava, como eu era coordenadora do, eu disso agora nós vamos fazer, né. Mas eram sete turmas de quarenta alunos com quatro professores, então nem preciso falar de algum problema deu, algum grupo faltou, não apresentou trabalho, ficou sem nota, e uma coisa que a coordenadora geral falou pra mim foi, por isso é que eu não gosto dessas coisas, cada um tem que cuidar da sua disciplina, então essa era a cara da escola, cada um cuidando da sua parte. Então, o que aconteceu com a escola, eu também sai né, mas uma amiga que está lá, me disse que eles estão com o projeto do lixo, ou da reciclagem, mas é assim, chegaram e disseram, olha cada um tem que falar de desertificação, que foi tema recomendado pela Unesco para este ano. Me parece que as escolas filiadas à Unesco tem que trabalhar com projetos, elas são (des)filiadas e por isso elas têm esse compromisso.

$\mathrm{V}-\mathrm{P}_{10}$, esse projeto foi feito durante o período de aula, ou em período diverso?

$\mathrm{P}_{10}$ - No período de aula, aula nada fora.

V- Quer dizer, o professor trabalha aquele conteúdo ali e o projeto acontece naquele momento. $\mathrm{P}_{10}$, quando você esse trabalho é interdisciplinar, ou ele seria neste momento inter e em outro multi, com você vê isso?

$\mathrm{P}_{10^{-}}$[O multidisciplinar pra mim é assim, você põe um tema e cada um vai lá e trabalha aquele; então você põe um tema desertificação, química trabalha a desertificação, geografia trabalha, física trabalha, do seu jeito, isso pra mim é multidisciplinar, não se 
comunicam.] (8) Agora, ser [interdisciplinar é ter uma comunicação, é você tentar mostrar que as coisas elas são juntas, que existe os componentes curriculares, mas eles tratam do objeto.] (9) Eu me lembro de uma transparência, em que eu tinha feito o curso da universidade da "metodologia do trabalho interdisciplinar" pra dava medo porque ela falava inter, pluri, mult e trans. E a transdisciplinaridade era a antropologia, que era o exemplo que havia na transparência da transdisciplinaridade, eu não usava esse material, porque pra mim isso nunca ficou claro, eu saí do curso, porque essa diferença que nós corrigíamos nos trabalhos dos alunos, entre nós professores também tínhamos essas diferenças, isso é inter, isso não é inter, cada um achava uma coisa, talvez a gente não estivesse preparados o suficiente para fazer aquela avaliação, talvez não, com certeza.

V- Foi uma boa tentativa; agora a escola pública como ela está posta hoje, com as suas dificuldades, disciplinar, com os horários de HTPCs, você acha possível fazer um trabalho interdisciplinar? Você que isso é realmente possível?

$\mathrm{P}_{10^{-}}$Eu acho que é, eu acho mesmo, Valdir eu tenho um trabalho assim, tem hora que falo eu não tenho mais fôlego, eu fiquei sete anos nesta ultima escola, tentando fazer da química um trabalho diferente, eu saí e pessoa que está lá há mais tempo, que é tradicional, é coordenadora da área de química agora. [Eu não tenho dúvida que é possível fazer um trabalho interdisciplinar desde que o professor tenha clareza disso], (10) acho que [toda questão está na formação do professor,] (11) porque se ele não acredita, ele não vai conseguir fazer nunca. [E isso vem de fora, só de fora como uma imposição, pra quem acabou de chegar, ou está lá a quarenta anos.] (12)

V- E formado disciplinarmente. mesmo.

$\mathrm{P}_{10^{-}}$Isso, pra quem foi formado pela 5692 pela 9394, uma questão de formação mediação.

V- Uma ruptura de paradigma difícil, por tem que haver alguém que faça essa

$\mathrm{P}_{10^{-}}$Mas ela tem que ser feita, nós não podemos desistir, as nossas crianças têm que ficar mais tempo na escola.

V- Me parece que a Escola de Tempo Integral vem atender à isso, né? Tomara que não seja, apenas uma estratégia com fins políticos, espero.

$\mathrm{V}$ - $\mathrm{P}_{10}$ - quero agradecê-la pela disponibilidade, foi um prazer. 
Entrevista: $\mathrm{P}_{11}$

Leciona (ou) na escola pública: 02 anos.

Particular: 01 ano.

Formação: Licenciatura em Química

Instituição: Universidade Federal de Juiz de Fora-UFJF

Período: 1999-2004

Pós-graduação nível: mestrado

Início: 2005

Instituição: Universidade de São Paulo-USP

Data: 21/06/2006

Tempo Total: 26 min.

$\mathrm{V}^{48}-\mathrm{P}_{11}$, o nosso trabalho será sobre a concepção de interdisciplinaridade dos professores química do Ensino Médio, e aí a gente está pensando em ouvir os consultores que trabalharam com a interdisciplinaridade, entender as concepções deles, ouvir alguns alunos da pós-graduação, que passam pela pós e que tiveram disciplinas de ensino, e tentar entender concepção desses alunos sobre interdisciplinaridade. Então, qual o critério que a gente usou: não pegar alunos no início das disciplinas, pegar alunos que terminaram as disciplinas e que tenham agora uma formação de ensino e tentar entender as idéias deles de interdisciplinaridade. E discutindo do com a professora Carmen, a gente pensou em falar com você. Então, a questão é essa, entendeu? Um bate-papo; onde a gente gostaria de saber se você em algum momento já ouviu falar da interdisciplinaridade, quando você ouviu? Como que foi esse contato que você teve com a interdisciplinaridade?

$\mathrm{P}_{11}{ }^{49}$ - Eu comecei a ouvir falar um pouco da interdisciplinaridade, quando eu comecei a estudar para fazer o curso de mestrado, durante [a graduação ouvia muito por alto as pessoas falando em interdisciplinaridade, transdisciplinaridade,] (1) mas [não sabia realmente o que era nada daquilo,] (2) mas aí quando eu comecei a pensar em fazer o mestrado, eu me aproximei de uma professora da universidade, e ela propôs que a gente começasse estudando algumas coisas sobre o ensino de química, e aí em meios a livros, das leituras que ela me indicava, gente discutia e apareceram esses termos, interdisciplinaridade, transdisciplinaridade, onde eu tive um pequeno contato com o que seria, mas nunca estudei profundamente o que era. Foi mais um conhecimento mesmo, para eu saber alguma coisa sobre o assunto, aí que eu comecei a ver sobre isso, [mas na graduação eu não vi nada disso.] (3)

V- E da pós, o que ficou das disciplinas de ensino, você teve algum contato, alguma coisa com isso, ou de certa forma você amadureceu um pouco mais, que você acha?

$\mathrm{P}_{11^{-}}$Bom, aqui no curso, a disciplina do Nilson que é Tópicos em Epistemologia, que ele falou um pouquinho de interdisciplinaridade, trabalho interdisciplinar, mas pelo menos pra mim, foi uma coisa muito rápida, ele não aprofundou, a gente conversou um pouco sobre interdisciplinaridade; [aqui nas disciplinas do ensino de química que eu ouvi falar um pouco mais,] (4) as pessoas dizendo da necessidade da interdisciplinaridade, do trabalho interdisciplinar, os seminários de ensino, lá da Física que eu ouvi falar um pouco

\footnotetext{
$\mathrm{V}^{48}$ Refere-se ao entrevistador: Valdir Pedro Berti

$\mathrm{P}_{6}^{49}$ Refere-se ao entrevistado
} 
mais, mas nem isso centrado na interdisciplinaridade, [só em bate-papo mesmo sobre o assunto.] (5)

V- Você arriscaria, com os materiais de estudo fornecido pela professora na universidade, com a vivência da pós-graduação, com a disciplina do professor Nilson, você arriscaria definir, ou falar o que você acha que seja isso, ou como é possível fazer um trabalho interdisciplinar, você tem isso em mente?

$\mathrm{P}_{11^{-}}$Eu tenho uma idéia, eu acho [que um trabalho interdisciplinar dentro de uma escola,] (6) acho que [não função de um professor,] (7) porque às vezes a gente ouve falar muito assim, o ensino de química tem que privilegiar a interdisciplinaridade, e aí [fica parecendo que o professor de química sozinho tem que ser capaz de desenvolver em cima de um assunto só toda a interdisciplinaridade possível] (8), ou seja, [fazer uma abordagem biológica, social, física, histórica, geográfica, e que o assunto der abertura] (9) para ser feito. Eu acredito que isso já pra mim não seria interdisciplinaridade, ela não seria exatamente isso, um único professor tendo que ter todas essas, tendo o conhecimento de todas essas especificidades. A interdisciplinaridade é atributo mais da escola e do sistema de educação que a escola adota, do que o professor, ou seja, através de um trabalho, por exemplo, com projetos você consegue uma interdisciplinaridade, o aluno vai ter contato com uma interdisciplinaridade, mas ela não vai ser responsabilidade, somente de um professor, mas de todo o quadro de professores; então [acredito que interdisciplinaridade é que vai ser trabalhada por todos, e que o aluno vai se beneficiar, porque ele vai ter o contato com cada professor dessa especificidade, aí os professores conversando antes, combinando quem vai abordar qual ponto, qual aspecto que seria o mais interessante abordar de um assunto, aí você consegue varrer o mesmo assunto com um espectro maior de disciplinas.] (10)

V- Então, seria na perspectiva dos professores fazendo a interdisciplinaridade e não professor fazer a interdisciplinaridade? Fazendo uma certa ruptura epistemológica de uma disciplina. É na perspectiva dos professores?

$\mathrm{P}_{11}$ - Isso, isso.

V- Você acha que na a escola pública de educação básica, teria condições de se fazer um trabalho interdisciplinar? Como a escola está posta hoje?

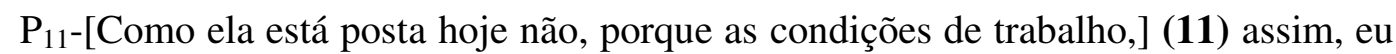
acho muito interessante, [porque existe um discurso do que tem ser feito, no sentido da educação melhorar,] mas aí[quando você entra dentro da escola, você vê que as condições de trabalho não favorecem o estabelecimento dessas atitudes, que esse discurso coloca, então, por exemplo, nas escolas que eu trabalhei em Juiz de Fora em Minas, o que eu vi foi que a diretora queria que a gente fizesse um trabalho legal, interdisciplinar, tudo mais, só que no meu caso, cada noite eu dava aula em uma escola diferente;] (12) isso quando eu comecei a trabalhar com o ensino modulado educação de jovens e adultos e quando eu comecei a só trabalhar só com Ensino Médio mesmo, é [praticamente cada uma das noites] (13) eu, também estava em uma escola, eu tinha que dividir o horário do noturno em três escolas, então aí você não tem esse tempo de estar em contato com a escola e se dedicar 
realmente para que haja esse trabalho, porque precisa que os professores se reúnam, assentem, conversem desenvolvam um projeto, estabeleçam o que será feito e na prática esse tempo, pelo menos lá, não existia.

V- Há um discurso para se fazer, mas as condições efetivamente não são dadas.

$P_{11}$ - Não são favoráveis para que isso aconteça.

V- Agora, digamos se as condições fossem favoráveis para fazer, você acha que a interdisciplinaridade ela vai prejudicar o conteúdo de química, ela vai dar um olhar mais abrangente e significativo, ou quer queira quer não, o professor em algum momento, você acha que trabalhar de forma interdisciplinar sacrifica a questão do conteúdo, como você vê isso?

$\mathrm{P}_{11}$ - Eu acho o seguinte, o currículo de todas as disciplinas escolares estão saturados de coisas para serem trabalhadas, então quando eu entro com uma proposta diferente dessas, como uma proposta de se trabalhar essa interdisciplinaridade tenho que fazer uma opção, alguma coisa você vai ter que tirar para colocar esse tipo de trabalho no lugar, porque é um trabalho que vai desprender bastante tempo, também; então os professores deveriam assentar e ver o que poderia ser retirado desse currículo que a gente já tem, em função dessa abordagem interdisciplinar, porque essa abordagem, ela aborda muitos aspectos, que o ensino que a gente aborda disciplinarmente, não aborda hoje, né? Tipo, você trabalha muito em cima só dos conceitos, e na abordagem interdisciplinar, foge dos conceitos, você não fica só naquela coisa conceitual. Então, eu acho que é possível, [mas os professores têm que assentar, discutir e pensar o que ele vai tirar de conteúdos, que ele tem que tirar alguma coisa de conteúdo, porque não tem espaço. é tempo mesmo. E nas escolas esse tempo para se trabalhar isso na escola; então, eles vão ter que optar o que ele acha que poderia ser retirado naquele instante que não prejudicaria o aluno, no sentido dele fazer, talvez ele fazer um concurso depois, não sei, depende do objetivo da escola e colocar essa proposta interdisciplinar em funcionamento, então eu acho que para entrar essa proposta, tem que tirar alguma coisa do conteúdo, não da pra colocar mais uma coisa no currículo, vai inchar mais ainda e não tem espaço para essa abordagem tão conceitual como é hoje.] (14)

V- Mas você acredita na proposta, faria ou acha que é um modismo?

$\mathrm{P}_{11^{-}}$Eu faria, acho interessante, sou suspeito para falar que faria, porque minha proposta do meu projeto de mestrado é um trabalho totalmente interdisciplinar com química, então você tem os conceitos chaves que você vai trabalhar, mas o objetivo da aprendizagem ali é superar esses conceitos chaves e aí pegar uma abordagem mais abrangente, social, histórica, links com outras disciplinas, esse tipo de coisa, então nessa proposta.

V- Você já deve ter ouvido falar em transdisciplinaridade, intradisciplinaridade, multidisciplinaridade, ou seja, os palavrões que a educação traz no dia-a-dia. Você arriscaria falar sobre alguma coisa dessas, ou fica na interdisciplinaridade. Gostaria de emitir alguma opinião sobre isso, ou não? 
$\mathrm{P}_{11}$ - Bom, eu vi e não posso falar que não, porque você está de prova, pois vimos juntos na disciplina do Nilson (risos!), mas eu não me lembro exatamente todos esses conceitos.

V- Eu não estou preocupado com as definições, mas o que você depreendeu disso, entendeu?

$\mathrm{P}_{11^{-}} \mathrm{O}$ que ficou pra mim, é que interdisciplinaridade seria você abordar um assunto, através de várias disciplinas, sob ótica de várias disciplinas, a transdisicplinaridade é que é pra mim mais complicada, não me lembro qual era a definição.

V- Mas, para você, o que você acha?

V- E a intradisciplinaridade, soa pra você, como?

$\mathrm{P}_{11^{-}}$Intradisciplinaridade parece para mim que [é trabalhar dentro, dentro de uma mesma disciplina você transitando sobre os conceitos delas,] (15) porque às vezes a gente estuda; igual acontece no próprio Ensino Médio, em que a gente aprende uma coisa de química aqui, que [a gente diz que é atomística e depois aprende uma coisa de cinética e é só cinética.] (16) [Então você tem vários conceitos que poderiam ser trabalhados ao mesmo tempo,] (17) [estar transitando entre um e outro,] (18) mas eles estão em pacotes separados dentro do próprio Ensino Médio, [fazendo links dentro da própria disciplina,] (19) me parece que é isso. E a transdisciplinaridade seria, imagino que você aborda, eehhhh!...

V- O que você acha que se quer quando se propõe trabalhar com a interdisciplinaridade, qual é o objetivo, quando se propõe trabalhar interdisciplinar. O que os professores que a fazem podem ganhar com isso?

$\mathrm{P}_{11}$ - O professor ou aluno?

$\mathrm{V}$ - O professor quando aplica e o aluno quando recebe. Como você enxerga. Como você olha pra isso?

$\mathrm{P}_{11^{-}}$Eu acho que esse trabalho interdisciplinar para o aluno mais vantajoso, porque através deste trabalho o aluno conseguiria ter uma idéia mais continua do mundo, por exemplo, de que as coisas e conhecimento são separadas, não existe um conhecimento de Química, um de História, um de Geografia de alguma forma todos eles estão relacionados uns com os outros, e que quando a gente vai, por exemplo, quando a gente vai olhar um fenômeno que aconteça que seria, talvez somente da química, a poluição do rio tal, entendeu? A abordagem só química disso seria a do tipo de poluente que está ali, estudar uma forma de preservar, talvez isso, mas isso é muito pobre frente quais fatores que levaram àquela poluição, porque foi poluído? Se foi a industria? Desde quando acontece? Que é uma abordagem mais interdisciplinar.

V- Ele teria uma olhar mais fragmentado? Ou seja, ele olha para um ponto e só vê aquilo. No geral ela teria a idéia da situação real, ou seja, da situação exatamente como ela 
é. Uma visão que busca dar sentido e significado e isso?

$\mathrm{P}_{11^{-}}$Exatamente, é isso, mas acredito que é assim, dar um significado mais abrangente pra coisa, do que simplesmente a visão da química, da história, ou da biologia, aquela coisa fragmentada, separada.

V- Bom, isto para o aluno, você acha que o professor quando encara esse tipo de proposta, ele busca a mesma coisa? O que ele está buscando?

$\mathrm{P}_{11^{-}}$Ai eu vou dizer, enquanto professor de química, quando eu busco uma abordagem assim, meu objetivo é justamente que o aluno tenha um entendimento maior de química, não se restringindo somente na questão conteúdo; então ele vai ter entendimento das interferências sociais do conhecimento da química, históricas, relações com outras disciplinas, eu estou dizendo isso, porque quando no meu projeto eu trabalho, é um projeto que o objetivo é interdisciplinar, também, por que a abordagem é de um tema bem amplo que seriam agrotóxicos, mas aí a gente não se limita só ficar na abordagem química, a gente se preocupa com fatores sociais sócio-econômico, então eu como professor, quando faço isso, meu objetivo é fazer com que o aluno enxergue a ciência não só pelo viés do conhecimento científico, mas como ela é produzida, o que é que influência nas decisões, esse tipo de coisa. a-dia dele?

V- Ou seja, interligar esse mundo da ciência ao conhecimento, ao cotidiano, ao dia-

$\mathrm{P}_{11}$ - Pela própria tomada de decisões que ele tem no dia-a-dia, quando ele vê num jornal, por exemplo, puxa alguém foi contaminado com agrotóxico, isso é culpa de quem? De quem produziu o agrotóxico, será? Não tem as medidas de segurança? Então, a pessoa que foi contaminada desrespeitou essas medidas de segurança, então será que a culpa é do produtor mesmo? Ou será que, pra que existe esse agrotóxico? Será que é necessário mesmo? E aí entra a relação, custo-beneficio, esse tipo de coisa tipo de coisa.

V- Essa formação cidadã, ser capaz de tomar decisões, interferir na realidade, de emitir uma opinião. É isso que, pelo menos, você buscava?

$\mathrm{P}_{11}$ - Exatamente, porque eu acho que está relacionado com você ter uma visão mais abrangente do que é ciência, também.

V- Digamos que os professores trabalhassem na situação ideal, como condições de trabalho, se os professores tiverem uma proposta interdisciplinar se eles sentarem e discutirem; isto você acha possível fazer esse trabalho?

$\mathrm{P}_{11}$ - Acredito que sim.

V- Eles vão determinar o que o conteúdo de química trabalha, o conteúdo de física trabalha, o conteúdo de biologia, enfim os demais conteúdos.

$\mathrm{P}_{11^{-}}$Isso, isso, pensa-se no assunto e por meio desse assunto, o que eu posso 
abordar.

V- E esse assunto, eu da química, o outro professor da física, da biologia, de português, nós teríamos que socializar cada assunto ou cada qual pega o seu.

$\mathrm{P}_{11}$ - Não, não, combinado.

V- Combinado e estudado, como você vê isso?

$\mathrm{P}_{11^{-}}$Eu pensaria, o seguinte: assentam os professores e discutem, é qual assunto que seria importante para o nosso aluno ter conhecimento? Olhando o cotidiano, quando eu digo cotidiano é a vida deles hoje. O que geralmente eles fazem, mais ou menos para você ter o perfil dos alunos dessa escola e [selecionar um assunto qualquer e depois de selecionado esse assunto pensar aí pensar uma abordagem mais química desse assunto poderia ser isso. Uma abordagem mais biológica poderia ser essa, então como a gente vai desenvolver esse trabalho? Primeiro escolher um assunto e depois cada um poderia ver qual seria o enfoque próprio, de cada uma das disciplinas e dialogarem disciplinas com disciplinas.] (20) Seria isso?

V- E daí sairia um material pronto, cada professor iria para sua aula e desenvolveria.

$\mathrm{P}_{11^{-}}$Sim, poderia ser. Poderia ser, também [o trabalho desses professores numa aula mesma aula; dependendo da estratégia de ensino que vão adotar. Os Dois professores juntos em esquema de debate numa sala,] (21) um professor de química e biologia e turma toda, iniciando um debate e [de acordo com tipo de questionamento que vão aparecendo, entra o professor de química ou de biologia, ou de física.] (22)

V- Fazendo complementações de acordo com a disciplina.

$\mathrm{P}_{11^{-}}$Exatamente.

$\mathrm{V}$ - O professor do conteúdo vai dar o esclarecimento da disciplina dele, mas você acha isso na perspectiva dos professores e não um professor, por que?

$\mathrm{P}_{11}$ - Porque, eu acho que isso sobrecarrega mais ainda o professor, hoje o professor tem que estar preocupado em fazer a própria dele, o que consiste em planejar a aula estruturar a aula que vai dar, só que ele precisa planejar todas as aulas que ele vai dar durante a semana, e ele da aula em três ou quatro escolas. Isso às vezes por turno, lá em Juiz de Fora eu dava aula em três escolas só à noite. Então, ai se você pega outro curso ai entra a estrutura que você tem para poder fazer esse tipo de coisa que a gente não, quer dizer, precisaria que o professor tivesse um tempo maior de disponibilidade. $\mathrm{E}$ aí dentro do quadro que a gente já está, com todas as dificuldades de formação, de trabalho e salário tudo você colocar para um único professor desenvolver tudo isso, acho que fica impossível, porque ele vai ter que conta não só do que ele já sabe da formação específica dele, mais vai ter que gastar um tempo ainda muito maior, pesquisando das outras áreas pra sozinho tentar fazer esse trabalho. 
V- Ou seja, tentar fazer essas rupturas?

$\mathrm{P}_{11}$ - Exatamente.

V-É uma proposta pouco, viável?

$\mathrm{P}_{11^{-}}$Quando mudarem as condições de trabalho, talvez ele possa fazer isso sozinho.

V- A propósito, você faz um trabalho interdisciplinar e como você avalia isso? Cada professor formula uma prova, como você vê isso? No final como que eu traduzo de uma forma para diagnosticar esse aluno está compreendendo mais, se eles tem uma visão não fragmentada desses, uma vez que ele está trabalhando de uma forma interdisciplinar. Você pensou em algum momento na questão da avaliação?

$\mathrm{P}_{11}$ - Acredito que a avaliação fique um pouco mais complicada, no sentido de que no início estabelecer os seus objetivos dessa atividade, porque se você estabelece que o objetivo dessa atividade é simplesmente desenvolver conteúdos, aí desde do início já começou errado, porque no final você vai dar uma prova para saber se o sujeito sabe conteúdo, daí pronto, já estragou tudo. Então, no início você tem que pensar, meu objetivo é que ele desenvolva esse tipo de raciocínio, entenda esse aspecto do assunto, esse ou esse e aí no final talvez você faça uma avaliação sobre isso, ou então mesmo acompanhando o desenvolvimento do trabalho dos alunos, coisas pontuais, menos separadas, mas acho que a avaliação tem que ser condizente com o objetivo inicial. Se você optou por retirar parte do conteúdo para desenvolver com os alunos um conhecimento mais abrangente, então no final você tem que avaliar nessa perspectiva também, você não pode chegar no final e perguntar pra ele o que é átomo.

V- Ou seja, você faz toda uma estratégia de trabalho e no final você volta a aferir apenas os conteúdo,

$\mathrm{P}_{11}$ - Pois é, não dá (risos!)

V- Incoerentemente com a própria proposta.

$\mathrm{P}_{11}$ - Exatamente.

$\mathrm{V}$ - $\mathrm{P}_{11}$, muito obrigado pela sua disponibilidade, foi um prazer conversar com você, sobre os esclarecimentos sobre interdisciplinaridade. 
Entrevista: $\mathrm{P}_{12}$

Leciona (ou) na escola pública: 30 anos.

Particular: 03 anos

Instituição: Universidade do Oeste Paulista-Unoeste

Período: 1973 -1975

Formação: Licenciatura em Química

Data da entrevista: 21/03/2006

Tempo Total: 33 minutos

$\mathrm{V}^{50}-\mathrm{P}_{12}$, eu vou voltar no tempo para você se situar melhor, eu não sei se você se lembra, mas em dois mil e três nós tentamos fazer um trabalho por projetos interdisciplinares para o Ensino Médio, lembra-se daquela experiência? E daí o que a gente fez, a gente chamou os professores na Diretoria, com os diretores e coordenadores e começamos falar da proposta do Ensino Médio, que nós queríamos um trabalho por projetos interdisciplinares, aí fizemos reuniões, oferecemos um curso aqui de cinqüenta horas para os professores aos sábados, que os professores fizeram, um curso reconhecido pela CENP (Coordenadoria de Ensino e Normas Pedagógicas) e enfim e no final do anos nós fazíamos aquelas reuniões, onde fazíamos a socialização dos projetos. O que queria falar com você, primeiro que você é professor de química e conhece os conteúdos de química, mas o que eu gostaria de saber é se você já tinha ouvido falar da interdisciplinaridade, ou foi a partir daí ou foi antes, quando que isso aconteceu na sua vida? Teve experiências anteriores, conta um pouco disso pra gente.

$\mathrm{P}_{12}{ }^{51}$ - Valdir, o trabalho interdisciplinar, ele não é novo assim não, já vem de bastante tempo, só que esse trabalho interdisciplinar, ele era colocado, assim, não era mais direcionado e nem coordenado por uma equipe técnica pedagógica da Diretoria de Ensino, até então. Infelizmente, tentava-se fazer um trabalho interdisciplinar, mas haviam alguns professores que até hoje e você sabe muito bem não haviam tentado, até hoje existe professores resistentes. Bom, com os assistentes técnicos pedagógicos e os supervisores, especialmente o professor "Boso", que começou a coordenar o [trabalho interdisciplinar, através de projetos que a forma mais coerente de se trabalhar,] (1) né? interdisciplinarmente, multidisciplinarmente, a coisa começou a engrenar mais, a resistência começou a diminuir. Houve a coordenação de vocês, houve o apoio técnico, pedagógico, os projetos começaram a aparecer, os projetos começaram, os projetos foram socializados a nível de Diretoria de Ensino, aquelas reuniões que eram feitas no salão da COPLAP (Cooperativa dos Produtores de Leite da Alta Paulista), e a partir de aí, eu acho que a coisa está funcionando mais, por exemplo, a nossa escola a gente trabalha muito esse aspecto do projeto, inclusive esta escola se inscreveu em vários concursos e foi vencedora com projetos que a gente desenvolve ali, enfim eu acho que isso deveria dar continuidade. Agora, mesmo nós estamos retomando a fase dois do Ensino Médio que fala muito sobre currículo, inclusive o apelo principal da fase dois do ensino Médio em Rede é currículo, nós vamos ter na fase dois o professor representante da área. Um professor representando cada uma das áreas, além do coordenador pedagógico que teria assim, três assistentes, dentro do projeto com os demais professores, e eu creio que tudo isso aí vai acabar contribuindo sobremaneira para o trabalho com projetos, para a interdisciplinaridade,

\footnotetext{
${ }^{50}$ Refere-se ao entrevistador: Valdir Pedro Berti

${ }^{51}$ Refere-se ao entrevistado: $\mathrm{P}_{12}$
} 
principalmente para se fortalecer dentro da escola e levar o nosso aluno ao objetivo máximo da nossa escola que é preparar esse aluno para a vida, formar esse aluno cidadão deixá-lo critico, e através de projetos eu acredito ser o caminho mais curto e mais coerente.

V- E nesse trabalho que os professores estavam e estão desenvolvendo, na questão de conteúdo e disciplina, por exemplo, disciplina de química, de física, de matemática, você acha que o professor conseguiu trabalhar os conteúdos, ou não conseguiu, era um nó, qual a avaliação que você faz disso?

$\mathrm{P}_{12^{-}}$[O trabalho com projeto não for contextualizado, não adianta, se os professores, principalmente entre as áreas,] (2) entre as três grandes áreas se o professor não incutir, se ele não puser na cabeça dele que ele tem que contextualizar para trazer esse conteúdo para o aluno de forma interdisciplinarmente, não tem jeito de se trabalhar com projetos; agora trabalhando de maneira interdisciplinar, contextualizada, trabalhando de maneira mais específica, os professor tem tempo e é o que eles vêem pedindo, a muito e a gente tem dado essa abertura e discutir em partes de HTPCs (Horas de Trabalho Pedagógicos), e já temos HTPCs de uma hora para os [professores se reunirem por área e discutirem até aonde, por exemplo, a Matemática vai trabalhar, a partir da aonde a Química vai trabalhar, a partir da onde a Biologia vai trabalhar, levando isso de forma contextualizada,] (3) eu acredito que vai sair um trabalho perfeito, na minha escola eu posso dizer isso aí, por a gente tem conseguido, por exemplo, eu vou dar um exemplo a grosso modo nós tivemos um apelo para trabalhar a dengue; então que nós fizemos, para trabalhar a profilaxia, porque estava tomando a proporção de epidemia na nossa região, então o que nós fizemos, conclamamos os professores, principalmente os orientadores de classe, independente da disciplina, o professor de matemática, ele é orientador de classe do primeiro ano, então você vai trabalhar a profilaxia da dengue na classe que você é orientador, independe se você entende ou não, eu não quero, digamos assim, que você chegue lá e dê uma aula de fisiologia, ou que você chegue lá e dê uma aula de infectologia, ou de virose, não, não é isso que quero de você; [eu quero que você trabalhe a profilaxia da dengue.] (4) Então, o que ele vai ter que fazer? [Ele vai ter que socializar junto com Biologia, junto com Química, ele vai ter que saber alguma coisa para falar para o aluno a respeito disso, então isso] (5) aí é um pequeno projeto mais é um projeto, é um projeto que vai se encaixar no atual projeto que nós estamos desenvolvendo agora que são, "Os Problemas Globais e as Soluções Atuais".

V- Então, me parece que ele acaba tendo que dialogar com esses professores, estudar e aprender, correto?

$\mathrm{P}_{12^{-}}$Com certeza.

$\mathrm{V}$ - Eu acho que é um desafio, mas é possível. Agora você como professor, os espaços das HTPCs, eles forem bem divididos e planejados, eles são suficientes para se trabalhar os projetos interdisciplinares, ou não. O que você acha?

$\mathrm{P}_{12}$ - Não são suficientes, os professores precisam de mais tempo pelo seguinte, se a gente dosar e dividir direitinho o tempo, a gente acabar conseguindo, porque no fim de tudo na hora em que você trazer tudo para um objetivo comum, você vai ver que nós vamos precisar de dois HTPCs semanais para a gente trabalhar o Ensino Médio em Rede, isso 
apenas faça as atividades. O Ensino Médio em Rede por sua vez, vai estar priorizando currículo interdisciplinar, então ele vai estar ajudando o desenvolvimento de projetos, quer dizer, é pouco HTPCs no momento pra muita coisa que tem que desenvolver em três horas de HTPCs semanal, isso pouco, a gente até reconhece que é pouco, mas sabendo dosar isso aí, sabendo levar esse conteúdo já preparado, sabendo levar essas propostas, já bem delineadas eu acredito que sim, e se faltar vai faltar muito pouca coisa.

$\mathrm{V}$ - $\mathrm{P}_{12}$, eu e você, nós somos da geração da formação disciplinar, nós tivemos uma educação básica disciplinar, conteudista, propedêutica fomos para a universidade com essa formação. Hoje, por exemplo, com essas propostas de trabalhos integrados, onde a química dialoga com a biologia, coma a física, a física com a química, etc. Onde você acha que esse espaço realmente se concretiza, você tem uma idéia, ou não, eu vejo isso em tais momentos, onde você vê isso?

$\mathrm{P}_{12}$-[Concretiza no dia-a-dia do professor, nos encontros que eles têm nas escolas, nas conversas que eles mantêm dentro e fora das HTPCs,] (6) por exemplo, vamos falar da química, né? [Química está número de Avogadro (seis, zero dois vezes dez elevado a vinte três, etc.), então ele vai precisar de um auxilio do professor de matemática para trabalhar potência de dez, então isso aí acaba acontecendo de maneira natural,] (7) [no desenvolvimento de projetos isso tende a acontecer de maneira mais sistematizada,] (8) isso normalmente acontece, porque o próprio professor pede auxilio para o outro.

V- E se você fosse fazer uma diferença entre essa questão da disciplinaridade, multidisciplinaridade e interdisciplinaridade, o que você daria como exemplo?

$\mathrm{P}_{12}$ - Basicamente, esse seria o exemplo, mas interdisciplinaridade [vai muito além de uma simples ajuda de um professor e de outro professor, a interdisciplinaridade no fim tem que acabar formando uma teia, formando um complexo disciplinar, digamos assim, em que todos falem a mesma língua,] (9) apesar de trabalharem sistematicamente conteúdos, digamos assim, não tão específicos, mas a gente acaba acreditando que no desenrolar de um projeto como eu falei no início pra você se ele tiver a orientação, a coordenação, apoio e principalmente apoio, da parte gestora, da parte técnica pedagógica, isso aí acaba acontecendo, porque o professor tem boa vontade, ele quer trabalhar dessa maneira e já percebeu que é uma forma até mais fácil dele trabalhar dele avaliar, dele discutir com o colega problemas que possam por ventura surgir com aluno, ou determinados tipos de alunos, ou mesmo diferenciação de trabalho em períodos, digamos assim, por projetos é mais fácil de se desenvolver no período noturno, é mais fácil, porque o período noturno requer um trabalho diferenciado, ou seja, tem tudo a vê com esse aluno; então o da manhã, vespertino já seria menos complexo de se trabalhar, né, também logicamente que se tem significado, mas a gente teria mais sucesso com aluno do período noturno.

V- Você tocou numa questão importante, que trata da figura do medidor, eu tenho notado que se não houver uma equipe gestora, ou o pessoal da Diretoria ou Universidade, onde isso for possível, mas se não houver a presença desses mediadores o trabalho dos professores me parece que o professor começa ficar assim meio inseguro em desenvolver, mas se houver o pessoal que lhe dê aporte me parece que a coisa flui, me parece que isso é fato, né? 
$\mathrm{P}_{12^{-}}$Valdir, não só mediar, mas ser um instigador, ele tem que ser teimoso, ele que bater de cima, tem que explorar tudo aquilo quer for possível; enfim não só intermediar, mas estar sempre "cutucando".

V- Mediar e provocar?

$\mathrm{P}_{12}$ - Mediar e provocar esse seria o perfil dessa pessoa para incentivar esse tipo de trabalho. Senão cai no desuso, no esquecimento no "hora veja"; então não funciona. Eu diria que não seria apenas uma pessoa, mas várias pessoas, a nível de escola, a nível de Diretoria de Ensino, digamos até a nível de Coordenadoria de Normas Pedagógicas e até da própria Secretaria de Educação priorizando esse tipo de trabalho.

$\mathrm{V}$ - $\mathrm{P}_{12}$, agora uma reflexão, você como eu que tem anos e anos

$\mathrm{P}_{12^{-}}$Trinta anos

V- Trinta anos de prática educativa e gostaria de uma opinião pessoal sua, você tem uma formação propedêutica, acadêmica e disciplinar, como a minha, e o que se fala é o seguinte, esse tipo de trabalho onde se procura integrar as disciplinas, onde se pretende fazer esses projetos interdisciplinares, transdisciplinares; enfim ele acaba prejudicando o conteúdo, o conteúdo específico, da química, da física, da biologia das disciplinas, o que você acha?

$\mathrm{P}_{12}$ Eu acho o seguinte nós vivemos num mundo que vamos dizer assim, até mil novecentos e noventa esse mundo engatinhou e a partir de noventa e um e dois, ele levantou e saiu correndo; então não tem mais como o professor ser detentor do saber, ser a única e exclusiva enciclopédia, porque o aluno de hoje é globalizado, ele está na televisão, na internet, ele está recendo um turbilhão de informações e o professor tem que filtrar isso, hoje o papel fundamental do professor é coordenar, é orientar, é direcionar, organizar, então ele deixou de ser o detentor do saber, mas por outro lado ele tem que se manter informado, até onde você diz que prejudica o conteúdo, eu tenho na minha concepção pessoal que não prejudica o conteúdo, porque o conteúdo de uma maneira ou de outra, o professor trabalhando ou não projeto ele vai passar o conteúdo, quer de uma forma mais amena, ou de forma mais complexa, ou mais direcionada, o aluno normalmente ansioso para saber mais daquele assunto, ele vários fatores, hoje que o auxilia a buscar mais informações sobre aquele conteúdo, eu acho que isso aí não seria o empecilho.

$\mathrm{V}$ - Eu acho sua analogia muito pertinente, e hoje nós temos que refletir o que é ser professor nessa conjuntura e complexidade. O professor tem que entender que o mundo mudou.

V- Agora, $\mathrm{P}_{12}$ essas palavras que educação coloca muito, como interdisciplinaridade, multidisciplinaridade, transdisciplinaridade, que acabam "soando" slogans, você teria algumas considerações a fazer? 
$\mathrm{P}_{12^{-}}$Eu acho que não tem outro caminho, senão o da transdisciplinaridade, eu acho que basicamente o centro de informações que é uma escola, onde nós o humano que é o aluno se não falarmos a mesma língua não se chega a lugar nenhum, principalmente por causa do atual momento que nós estamos vivendo. Então, o professor tem que fazer, no "fritar dos ovos", para se resumir mais a coisa, o professor não pode fugir da transdisciplinaridade, ele que contextualizar, estar ali, saber o que outro está fazendo, por que se ele não for atrativo, principalmente apara se tornar atrativo, porque se ele não for atração, o aluno tem muitas outras atrações e acaba deixando esse professor marginalizado, não tendo como e para quem vender o peixe dele, digamos assim.

V- E concorrente hoje é o que não falta.

$\mathrm{P}_{12^{-}}$Não, não falta (risos!).

$\mathrm{V}$ - $\mathrm{P}_{12}$, quero agradecer pela disponibilidade, por esse bate-papo, para mim foi extremamente produtivo, muito obrigado. 
Entrevista: $\mathrm{P}_{13}$

Email:

Leciona (ou) na escola pública: 17 anos

Particular: 08 anos

Formação: licenciatura e bacharel em Geografia

Instituição: Universidade Estadual de Londrina-UEL

Período: 1978-1983

Idade: 42 anos

Data: 03/04/2006

Tempo Total: $26 \mathrm{~min}$.

$\mathrm{V}^{52}$ - Estou pedindo para alguns professores; pedi para o $\mathrm{P}_{12}$, nós conversamos e eu gravei a fala dele e pensei em falar com você. A intencionalidade é falar um pouco, do trabalho que nós desenvolvemos em dois mil e três e dois mil e quatro.

$\mathrm{P}^{53}{ }_{13}$ - O projeto do ensino médio?

V- Isso, o projeto do ensino médio, que nós desenvolvemos aqui na Diretoria de Ensino. Cuja proposta era com projetos interdisciplinares. Então, o que eu quero, você tinha como professor entrado em contato com interdisciplinaridade, você conheceu interdisciplinaridade, você aplicou? Enfim, quando você se deparou com esse termo. Como foi isso?

$\mathrm{P}_{13}$ - A primeira vez que eu vi esse assunto eu estava para sair da universidade, isso foi em oitenta e seis. Quando se começaram os primeiros estudos sobre a importância de se relacionar uma disciplina com a outra e depois disso houve algumas discussões e aí nas escolas a situação é diferente, acabou, existe as disciplinas e cada um se vira. No ano de noventa e três com a implantação da escola-padrão é que deu para se colocar em prática alguma situação dessa de interdisciplinaridade, porque até então era apenas uma discussão teórica que existia a nível de escola, no máximo que acontecia, porque não existia HTPCs (Horas de Trabalho Pedagógico), mas daí em diante da proposta que foi feito de uma pesquisa, sobre a cidade que foi dividida em quatro temas, subtemas, bom foi aí que deu para encaminhar alguma situação do que seria a interdisciplinaridade, não deu para fazer com a escola toda. Então, a proposta da Expo-Tsuya como foi chamada, foi o resgate da cultura japonesa, porque foi da colonização japonesa a cidade de Bastos, diante disso, na verdade talvez aquilo não chegasse a interdisciplinaridade, mas cada matéria que pode saiu atrás para trabalhar, [então História e Geografia trabalharam de forma interdisciplinar, um exemplo que eu posso te dar nós fizemos uma pesquisa na feira, dos alimentos que se vendia, de onde vinham os feirantes, se eram produtores ou simplesmente feirante e com isso deu para encaixar três matérias, a historia aplicou questionário, a geografia foi ajudar na tabulação e matemática trabalhou a porcentagem e gente entrou (geografia) como uma ajuda de análise dessas informações,] (1) juntamente com história, então com isso a gente conseguiu resgatar um pouco da história, outras turmas da escola foram ver a questão cultural que veio do Japão. Então, com isso de novo entrou matemática, novamente para tabular as informações de cada família de aluno que a gente tem.

\footnotetext{
${ }^{52}$ Refere-se ao entrevistador: Valdir Pedro Berti.

${ }^{53}$ Refere-se ao entrevistado: $\mathrm{P}_{11}$.
} 
V- Me diga uma coisa, essa ajuda que você comentou da geografia para a história, a matemática com a história, isso era feito, com os professores, ajudando nas HTPCs, ou isso se estendia a sala de aula, geografia começava a trabalhar, matemática, como isso era feito? Ou tinha dois momentos, história fazia e vocês davam um suporte nas HTPCs, ou isso entrou para a sala nas disciplinas de vocês?

$\mathrm{P}_{13}$ - O que facilitou é que nós tínhamos [o coordenador de área, então história e geografia, ciências, matemática e português tínhamos áreas, e com isso com a reunião dos coordenadores e cada coordenador levava para a sua área, pra vê o que daria para encaixar no trabalho] (2) e existia a execução na sala de aula, porque não havia o encontro coletivo de todos, [mas nos corredores, salas dos professores, era o momento de trocar essas informações.] (3)

\section{V- Quer dizer que havia essa troca?}

$\mathrm{P}_{13}$ - Então, na verdade todos os alunos sabiam o que era esse projeto, porque todo mundo fazia essa linguagem. Agora, alguns componentes participaram de forma isolada, [porque que eu falo que o trabalho não foi interdisciplinar, porque o tema era em comum, mas o objeto de estudo era diferente.] (4)

\section{V- Você o caracterizaria como uma multidisciplinaridade?}

$\mathrm{P}_{13}$ - Aí sim, uma multidisciplinaridade. Então, área envolveu o estudo social e histórico, econômico conseguiu trabalhar junto, agora quando partiu para a área artística ficou um pouco distante. Isso foi no fundamental, no Ensino Médio nós não chegamos a mexer com muita coisa. O Ensino Médio partiu para uma coisa mais individualizada, que eu senti. O produto final para que via de fora dava a impressão que a escola toda trabalhou em conjunto, [mas isso não é possível porque vai da formação do professor, se o professor for formado com a noção de que a matéria é independentemente uma da outra,] (5) não como buscar a interdisciplinaridade (concepção epistemológica); então quando a formação do professor permite as ciências afins para um trabalho conjunto aí foi um sucesso.

V- Ou seja, a universidade teria um grande papel nessa formação.

$\mathrm{P}_{13}$ - Teria Valdir, porque [não é discutido o que é interdisciplinaridade,] (6) como o [professor terá como refletir através da leitura, o que está lá nos PCN,] (7) [não vai ter uma parte epistemológica pra entender certas situações,] (8) senão ele vai ficar no ah é, ah é? Querendo uma receita pronta. Então, como que faz? Agora, no ano de dois e três e dois mil e quatro, a gente conseguiu avançar um pouco disso. [O problema mais sério que eu vejo, a mobilidade de professores através de ingressos, formas de atribuição, remoção, não existe uma estabilidade no quadro de professores permanentes.] (9) Aí em dois mil e três o professor Fábio com essa formação propôs ensinar a metodologia de trabalho de desenvolvimento de projetos.

V- Eu me lembro disso. 
$\mathrm{P}_{13}$ - Aí foi muito importante, porque ele buscou dar a formação teórica aos professores, por que muitos acham que é fazer só projetos alguma pesquisa e apresentar o resultado disso, mas o que o aluno aprendeu, o que o aluno adquiriu de conhecimento, o que ele cresceu?

\section{V- Quais conhecimentos os conteúdos específicos que ele mobilizou, né?}

$\mathrm{P}_{13}$ - Aí na verdade cada um busca dentro de si o seu melhor, então estava acontecendo isso e aí diante disso, através do projeto "Lixo: vida ou morte" é que propiciou que algumas matérias trabalhassem de forma interdisciplinar, porque a parte das ciências humanas eu vejo mais facilidade de se buscar a interdisciplinaridade; agora quando vai para a área de exatas parece que eles têm ainda alguma dificuldade. Então, eu vou ajudar com dados de estatísticas.

\section{V- Os matemáticos, via de regra, só ficam nisso.}

$\mathrm{P}_{13}$ - Ou tirar a porcentagem de uma tabulação de uma pesquisa de campo, mas se esquecem da importância da análise dessas informações e como fazer a estrutura de tabelas e gráficos para associar a realidade de vida. Porque o problema social e ambiental do lixo não fica só números, mas a explicação é buscada em números. Ao passo que outra disciplina, o que eu vou fazer? Aí alguém tem que dar "cutucão", isso entra numa análise ambiental, então biologia pode trabalhar junto, você está mexendo com o meio ambiente. Agora, a física, e agora a física, né?

\section{V- E aí o professor começa a ficar meio perdido.}

$\mathrm{P}_{13}$ - Bom, se não dá para fazer neste momento fica fora, não há necessidade de todo mundo ao mesmo tempo desenvolver um mesmo tema. Educação artística, já partiu para o reaproveitamento do material e no final vamos diferenciar o que é reaproveitamento e o que é reciclagem que são duas coisas distintas e caminha o jogo, porque o trabalho de campo feito por equipe de alunos veio refletir dentro de uma análise. Aí teve um porém, uma turma que estava com outros professores, disseram já estamos cansados de ver o tema lixo, todo mundo vem aí e só falam de lixo, porque tanta fala de lixo? Então, foi o momento de se explicar para o aluno, [que existe um tema e que cada disciplina está buscando estudar dentro da sua especialidade alguma situação que envolva o conjunto do lixo na sua vida.] (10)

V- Talvez, o que falta para os professores que trabalham com essas propostas (projetos, temas geradores, situações problemas etc.) é dar o esclarecimento para o aluno que o conteúdo está sendo desenvolvido ali, que ele permeia esse processo, que ele é meio e não fim, mas ele está ali. Dentro de uma situação real, e o conteúdo está sendo usado para evidenciar isto. Talvez, faltou e tenha faltado esse esclarecimento do professor. Fazer uma conexão, talvez o professor não fez, porque ele não viu, talvez o desequilíbrio tenha sido muito grande e ele não conseguiu fazer isso, ou talvez por uma segunda hipótese que eu não gostaria de acreditar que seria propositalmente ele não tenha falado, para dizer no final não houve o desenvolvimento de conteúdo, para volta a forma antiga de trabalho. 
$\mathrm{P}_{13}$ - É e aí fica difícil analisar a situação porque é pontualmente, aí vai envolver a formação que eu digo do professor.[Infelizmente na formação de licenciatura não existe o componente no currículo chamado metodologia de pesquisa,] (11) pelo menos o que a gente tem visto, é que quem vai para o bacharel tem essa formação e quando se torna professor usa desse recurso para a sua prática na sala de aula. Por outro lado o professor que fez monografia na sua graduação ele tem uma noção de metodologia, e aí quando alguém propõe a [fazer projetos sem essa noção de metodologia, sem os devidos cuidados de estudo, ele mistura tudo, ele não sabe o que objeto de estudo, o que é conteúdo, e aí ele embola tudo no meio do campo,] (12) os alunos saem embolados e o resultado pode até sair.

V- Mas, com o resultado sem clareza.

$\mathrm{P}_{13}$ - Por outro lado, a gente percebe que essa situação do Ensino Médio está propiciando algumas discussões de grupo, a nossa escola começou desde do ano passado já tem uma equipe de professores, nós precisamos pensar no todo mundo e vê alguns temas que a gente possa trabalhar em conjunto.

\section{V- Interdisciplinar?}

$\mathrm{P}_{13}$ - Isso, tentaram fazer isso no começo do ano, mas se depararam com uma dificuldade, como fazer? [Diante do tempo de HTPC, que ainda é insuficiente para essa discussão, mais rica.] (13) [Alguns componentes parecem que conseguiram amarrar algumas coisas, mas quando envolve a área de Ciências da Natureza a coisa fica mais amarrada.] (14)

\section{$\mathrm{V}$ - Eu percebi isso também.}

$\mathrm{P}_{13}$ - Porque aí existe uma maior facilidade diante dos textos da área de humanas e história, então existe essa facilidade porque trabalha com uma linguagem escrita, diferente de uma linguagem codificada, que é de Química, Matemática, que é de fórmulas, que para nós não faz parte do nosso cotidiano. Então, existe algumas situações que aos poucos o Ensino Médio estão propiciando uma discussão. Hoje já se fala de uma possibilidade de articulação dentro da área; então, isso está de certa forma, levando a algumas discussões. Essa mudança não vai amanhã, daqui a dois anos. Essas discussões terão reflexões daqui a dois anos, elas terão reflexos um pouco mais pra frente, porque essa discussão de interdisciplinaridade já está a um bom tempo, mas colocar na prática é outra realidade.

V- Na discussão acadêmica ele se deu na década de setenta, no Brasil como uma discussão no campo epistemológico na década de oitenta, em noventa, com Ivani Fazenda ela vem para o campo metodológico, então temos aí, quantos anos? Dezesseis anos, contando de noventa pra cá.

$\mathrm{P}_{13}$ - E aí os PCN (Parâmetros curriculares Nacionais) são de noventa e oito, se não me falha a memória, então são oito anos. 
V- De proposta de trabalhos contextualizadas e interdisciplinares. Agora, você como professor com a sua prática em sala de aula, você acredita na proposta, acha factível? E com todas as dificuldades, o caminho é esse ou não é? Como você se coloca como professor?

$\mathrm{P}_{13}$ - O ideal seria esta forma interdisciplinar, até esses dias um dos textos do ensino médio escrevia assim: as escolas particulares do Ensino Médio que teriam o material didático, comprado já está trabalhando de forma interdisciplinar já educação infantil e que vem para o fundamental, agora quando chega no médio, aí torna-se aquela situação anterior.

\section{V-É a cultura do vestibular?}

$\mathrm{P}_{13}$ - Isso, agora nessa mesma análise eu vejo o seguinte, a escolha do livro didático, a escola escolhe pela equipe de professores que tem, mais direção e coordenação, só que nem sempre o livro escolhido chega como a opção na escola, chega a segunda opção, por outro lado nem mesmo os professores sabem como intercalar essas situações de conteúdos para trabalho, porque o livro acaba virando a bíblia para o professor, não é um recurso de apoio, mas acaba sendo a base. Então, como fica um trabalho interdisciplinar nessa situação, Ensino Médio, agora veio matemática e português e as outras disciplinas, como buscar essa situação, através de projetos? Como a equipe encara o desafio de ensinar por projetos, dentro de uma determinada turma, série, ano tem metade que mergulha com responsabilidade para a execução, ah, não deu tempo porque eu tenho que dá esse conteúdo primeiro, preciso aplicar prova, ele não encara que buscar conhecimento através da pesquisa, de uma trabalho de campo, de experimento é também aprendizagem.

V- Aprendizagem com significado.

$\mathrm{P}_{13}$ - E aí o aluno não entende?

V- Porque, ele está relacionado teoria e prática, e construindo o seu conhecimento, neste processo.

$\mathrm{P}_{13}$ - Agora, reproduzir o conhecimento é muito fácil, agora buscar a construção do conhecimento exige uma formação teórica muito bem concretizada para o professor executar.

V- E aí, voltada a sua fala, a de que nós teríamos que ter mais espaços nas HTPCs, para se construir isso, e o professores que não teve essa formação, buscar de alguma forma com os colegas, com a equipe de trabalho, ou curso de formação.

$\mathrm{P}_{13}$ - Porque também, tem muitos professores que recebem orientação técnica de boa qualidade, mas não colocam em prática, porque ele tem medo de entrar numa situação nova. Ele nunca fez uma pesquisa no concreto sozinho, talvez como nós fizemos essa oficina em dois mil e três, é um pouco de oficina, como proceder para fazer isso? Aí sim o professor com a sua prática consegue concretizar a teoria da interdisciplinaridade. 
V- É necessário que ele tenha alguma fundamentação teórica. Semelhante ao curso que nós oferecemos, e você não participou, mas nós desenvolvemos um curso reconhecido pela CENP (Coordenadoria de Normas Pedagógicas) e, dois mil e quatro de sessenta horas em que os professores em que os professores vinham na Diretoria aos sábados, em que eles tinham exatamente isso, a fundamentação teórica, e no final eles produziriam alguns projetos, alguma escolas produziram projetos, mas a partir do momento que o professor sentiu, que ele entendeu a fundamentação teórica, e que ele poderia realmente fazer aquilo. É necessário dar um tempo para que ele adquira essa confiança, se ele não tiver confiança ele não faz.

V- Agora, $\mathrm{P}_{13}$ me diga uma coisa, quando você falar em multidisciplinaridade, interdisciplinaridade, transdisciplinaridade. Isso pra você tem definições diferentes, você consegue pontuar, aqui é isso, ali é aquilo, ou para você trata-se apenas de uma polissemia de poucos significados.

$\mathrm{P}_{13}$ - Na verdade cada termo tem uma instância de trabalho, vamos dizer assim, quando a gente fala que é uma transdisciplinaridade [alguns temas ou conteúdos que estar permeando por todas as matérias obrigatoriamente, exemplos são os temas transversais, que todos os componentes curriculares, independente do que seja terá que fazer alguma inserção durante a apresentação do trabalho.] (15) Quando falamos em multidisciplinaridade é você dá o tema lixo, e aí cada, bom, então eu vou ver como se faz a compactação do lixo, ah, vou ver onde o lixo é jogado em ciências, como é feito o aterro, mas [sem amarrar o conteúdo todo] (16) não vão estar na interdisciplinaridade, a mesma coisa quando [um paciente está doente vai vários médicos e ninguém faz a situação diagnostica de cada profissional para saber o que tem para buscar a solução da doença.] (17) [E a pesquisa é mais ou menos por aí, cada um vai levantar a sua hipótese e se a gente não amarrar essas hipótese para a elaboração de tese, não busca a tese.]

(18)

V- A nossa conversa foi muito esclarecedora, penso que ficou explicito o que ocorreu na escola naquela época, o que vem ocorrendo, as dificuldades e avanços; enfim, muito obrigado pela disponibilidade. 
Professor: $\mathrm{P}_{14}$

Leciona na escola pública: 24 anos.

Particular:

Formação: Licenciatura em Química

Instituição: Unoeste (Universidade do Oeste Paulista)

Data: $17 / 10 / 2006$

Total: $23 \mathrm{~min}$.

$\mathrm{V}^{54}$ - $\mathrm{P}_{14}$, eu não sei se você se lembra, mas no ano de 2003 e 2004 a Diretoria de Ensino tinha para o Ensino Médio uma proposta de trabalho por projeto interdisciplinares, certo? Bom, então o que eu e o supervisor fizemos, chamamos o pessoal, começamos a conversar sobre a proposta, e ai a gente notou o seguinte, que algumas escolas fizeram projetos, ou seja, aconteceram bons projetos, outras escolas começaram; enfim eu gostaria de ouvir a sua idéia sobre isso?

$\mathrm{P}_{14}{ }^{55}$ - Eu tenho um ponto, eu notei que muita resistência, [os professores eles são muito arraigados, ainda no conteúdo, trabalhando o tradicional.] (1)

V- A questão que eu gostaria de entender e a seguinte? Você tinha ouvido fala sobre interdisciplinaridade, leu alguma coisa, já tinha feito algum curso? Como foi isso na sua vida? Como você entrou em contato com esta questão?

$\mathrm{P}_{14}$ - Ah, eu já tinha ouvido falar, né, mas nunca assim tinha tido nada, assim nenhum palestra, nenhum curso, nada! Foi uma experiência, assim nova, e que eu achei interessante e que a gente podia estar mudando um pouco a metodologia, fazendo com que [o aluno ficasse mais interessado, porque você sabe que hoje o grande problema é a motivação, o interesse.] (2) E com essa pedagogia de projetos, aquele ano foi um ano muito bom. [A gente pode resgatar o interesse do aluno pela escola, principalmente pelos conteúdos.] (3)

V- Isso você observava que acontecia, deu mais ou menos pra você ter uma idéia do envolvimento do aluno?

$\mathrm{P}_{14}$ - Sim, eu achei muito interessante, inclusive, todo mundo elogia esse projeto até o ano passado eu estava trabalhando em São Paulo e escrevi um artigo, onde usei esse projeto, lá na Teia do Saber. Onde a gente tinha que apresentar um trabalho, que a gente tivesse feito realmente na sala de aula.

V- Realmente, aquele trabalho foi muito bom!

$\mathrm{P}_{14}$ - Eu coloquei o trabalho interdisciplinar e apresentei o projeto que nós fizemos juntos na Diretoria de Tupã.

\footnotetext{
${ }^{54}$ Refere-se ao entrevistador: Valdir Pedro Berti.

${ }^{55}$ Refere-se ao entrevistado: $\mathrm{P}_{14}$
} 
V- Agora me fala uma coisa, você como docente de Química com a responsabilidade que você tem e a capacidade que a gente conhece. Você sentia naquele época quando se fazia a [aplicação deste projeto que o conteúdo ficava prejudicado? O que você achou?

$\mathrm{P}_{14}$-Não, não, não, pelo contrário,] (4) né, mais aí Valdir[cabe ao professor contextualizar o tema do(5) projeto com os conteúdos dele; então, é assim, o professor tem que ter um certo jogo de cintura, experiência pra ele contextualizar, para ele inserir os conteúdos com o tema daquele projeto.]

V- De certa forma, pinçar o conteúdo para aquele momento, mas o professor não tem o hábito de fazer isso.

$\mathrm{P}_{14}$ - Isso, isso, [ele não tem hábito de fazer isso, ele não tem costume, ele não tem formação, realmente não é fácil.] (6) Nós aprendemos lá na escola, né? É uma questão de formação. Inclusive hoje, até nas faculdades fala-se muito em seminários, [eles pregam muito a interdisciplinaridade, mas na prática a gente vê que não é fácil.] (7)

V- E como você acha que "rolou" está questão? Como você via a integração dos outros professores com relação ao tema? Como vocês faziam essa integração? Houve essa integração?

$\mathrm{P}_{14^{-}}$Houve, Houve, no começo foi um pouco difícil, eles se opõem, não queriam aderir né, mas com muito jogo de cintura, trazendo material de internet, livros, então tinha os professores mais empenhados. Até o coordenador, todos os materiais que a gente conseguia, a gente ia colocando numa pasta, numa estante, aí os professores, eles foram pegando, e perguntando, o que eu posso fazer em educação física e nós íamos dando idéias e [um ajudando o outro, uma cooperação e no fim aquele projeto lindo, maravilho contextualizado.

V- Isso ocorria nas HTPCs, ou pelos corredores?

$\mathrm{P}_{14^{-}}$Um pouco nas HTPCs, nos corredores, nas horas de folga], $(\mathbf{8})$ à noite, fora do horário, né; porque nós usamos muito a informática, então eles tiveram muitas aula de informática, então foi necessário trabalhar bastante fora do horário. Não digo todos os professores, mas os que estavam mais empenhados sim.

V- Na verdade, então para esses tipos de projetos são necessários mais espaços para esses estudos, você acha que isso ficou evidente?

$\mathrm{P}_{14-}$ Exatamente, ficou evidente.

V- E a questão do interdisciplinar, você percebia que acontecia como? Esses professores trocavam idéias sobre como trabalhar os conteúdos, como você viu isso? 
$\mathrm{P}_{14}-$ [A troca de idéias a todo momento, era no intervalo, ligava em casa, olha eu estou precisando de alguma coisa, você tem? Olha a internet aqui em casa não está funcionando, um ia à casa do outro, na escola, à noite era todo momento, a gente assim, trabalhávamos em conjunto sim, uns ajudando aos outros,] (9) porque sozinho não chega a lugar nenhum. Inclusive o apoio que nós tivemos da casa da agricultura, indo atrás, então todo mundo empenhado naquele projeto, Valdir.

V- E na questão dos conteúdos, você tem diversos conteúdos, como a matemática, a química, biologia, física; enfim. Existiu alguns momentos de discussão destes conteúdos? Por exemplo, você como professora de química, falava gente eu quero trabalhar orgânica, enfim vocês falavam sobre os conteúdos, ou falavam sobre metodologias; mas, as questões de conteúdos não chegavam a tocar. O que acontecia?

$\mathrm{P}_{14^{-}}$Quando a gente estava trabalhando, parece que alguns conteúdos se misturavam, a gente falava assim, mas e isto daqui será que eu trabalho em química, ou biologia parece que se misturavam tanto que era impossível de separar, mas na troca de conteúdos, houve momentos, mas não deu tempo pra gente discutir muito, porque era uma coisa nova, uma metodologia nova, não se deu tempo da gente se discutir os conteúdos, mas eu [discuti com o mais próximo de mim que foi biologia, então a gente discutia muito, você vai trabalhar, então eu não vou,] (10) porque se mistura tanto, era ciclo do carbono, ciclo do nitrogênio, se mistura tanto que tanto faz, tanto poderia trabalhar em química como em biologia;[então o que eu discuti mais foi física e biologia.] (11) Matemática não deu assim, para a gente entrar, mas eu percebia, que o professor saia e eu chegava e falava: meu Deus que maravilha! Como pode? Olha que esse professor está trabalhando neste projeto, eu ficava assim, maravilhada.

V- E depois desse projeto, vocês fizeram um outro, mas de lá para cá a escola continua fazendo projetos interdisciplinares, vocês professores continuam fazendo projetos ou deu uma parada?

$\mathrm{P}_{14^{-}}$Olha Valdir, no ano seguinte deu uma esfriada, que eu acho assim, a primeira coisa também, tem que ter responsável pelo projeto. E ninguém quer se responsabilizar, porque você tem que ficar, né, o que você está fazendo, tem que ficar cobrando. O que você está fazendo, tem haver uma cobrança, até que procura, porque você acaba se envolvendo tanto que, o professor de química acaba fazendo o trabalho de artes de tão envolvente que fica o projeto. Aí no ano seguinte, nós fizermos um projeto mais eu achei que não foi tão bom quanto o primeiro, que foi sobre drogas, mas o que eu gostei, também. E no outro ano eu não fiquei trabalhando nesta escola, porque eu fui para São Paulo e estou retornado este ano.

V- Entendi, mas atualmente, você observa que o pessoal estão fazendo projetos, ou não?

$\mathrm{P}_{14^{-}}$Olha Valdir eu não estou criticando, mas eu acho assim, e trabalhando o tanto que eu trabalho, eu acho que falta o fio condutor, tem tudo pra dar certo, mas falta assim, aquele momento, da pessoa responsável. Então, Valdir eu acho que falta, a pessoa responsável aqui, até meu coordenador, como o vice-diretor falou assim, vamos fazer um 
projeto e eu até dei uma sugestão para o tema "Qualidade de Vida" um tema abrangente para envolver a comunidade em geral, alunos, pais; mas só ficou no tema. Eu até andei procurando alguma coisa na minha área, porque eu gosto muito do que eu faço, não só pelo dinheiro, mas eu gosto muito do que faço. Eu acho que foge um pouco da rotina, o aluno, ele fica muito "bitolado" na sala de aula. E tem a questão da disciplina, eu acho que melhora, ele vai saber se comportar fora de uma sala de aula, por isso que eu gosto muito da pedagogia de projetos. Mas, eu acho que falta é uma pessoa que responsável, inclusive eu acho que vocês deveriam fazer mais reuniões sabe? Para haver uma continuidade, que não teve mais.

V- Não querendo justificar, mas eu me afastei do Ensino Médio, para o Bolsa Mestrado e não colocaram uma outra pessoa para dar continuidade ao trabalho.

$\mathrm{P}_{14^{-}} \mathrm{Ah}$ ! não sabia.

V- Talvez, essa tenha sido uma falha da Diretoria, neste sem sentido, para incentivar esse tipo de trabalho.

$\mathrm{P}_{14^{-}}$Porque, nos dois anos que você estava nós fizemos, depois eu fui para São Paulo e quando retornei, eu perguntei para o pessoal e aí fizeram mais projetos? Falaram que não.

V- Hoje qual é a sua interpretação da interdisciplinaridade? O que está faltando para isso dar certo?

$\mathrm{P}_{14-}$ Eu acho que falta incentivo, tanto da Diretoria, quanto dos próprios gestores para haver essa continuidade. Porque você sabe a tendência do professor é sempre o tradicional. Então, essa pedagogia do projeto, apesar da Teia, do O Ensino Médio em Rede bater em cima, ainda tem resistência. Ainda não está acontecendo como deveria, não adianta, né a gente tampar o "sol com a peneira", mas essa integração como tem que acontecer não está havendo. Então, fica aí o pedido para ter mais reuniões, mais incentivos.

V- Eu vou aproveitar que a Valéria que está aqui conosco, e é da Teia para fazer a sua reivindicação. Dar maior incentivo aos trabalhos interdisciplinares.

V- Acho que você tocou num ponto importante, que é o incentivo da Diretoria, da equipe gestora, não como cobrança, mas como incentivo, o professor precisa disso.

$\mathrm{V}$ - $\mathrm{P}_{14}$, obrigado pela disponibilidade foi um grande prazer essa nossa conversa. 
Entrevista: $\mathrm{P}_{15}$

Leciona (ou) na escola pública: 26 anos

Particular:

Formação: Licenciatura e Bacharel

Instituição: Faculdade Auxiliadora de Lins-FAL

Data: $21 / 06 / 2007$

Tempo Total: $25 \mathrm{~min}$.

$\mathrm{V}^{56}$ - Olha, $\mathrm{P}_{16}$ eu vou puxar pela memória a fim de situá-lo no contexto. Você se lembra que no ano de 2003 e 2004 a Diretoria de Ensino de Tupã, implantou uma proposta de trabalho para o Ensino Médio, na qual você e alguns professores desta escola participaram desse projeto, lembra-se?

$\mathrm{P}_{15}{ }^{57}$ - Claro, me lembro sim.

V- Então, o que eu gostaria de saber, o seguinte, você como professor de física, como você atuou no projeto, como foi a sua participação?

$\mathrm{P}_{15}$ - Na física a gente puxou o projeto, relacionando o funcionamento de máquinas, movimento, parte de mecânica e eletricidade.

V- Em qual dos projetos?

$\mathrm{P}_{15}$ - No projeto do amendoim, então nós fomos e levamos os alunos para visitar as maquinas na $\mathrm{CAMAP}^{58}$, os funcionamentos dos maquinários, a secagem.

V- Só você da física participou dessa visita, ou teve outros professores?

$\mathrm{P}_{15^{-}}$Não, não, houve a participação da química, também. E cada um puxava para a sua disciplina, lá na CAMAP tinha a secagem do amendoim, armazenagem e limpeza, funcionamento dos maquinários todos. Então, deu para relacionar muitas coisas com as disciplinas.

V- E nessa abordagem você verificou que era possível trabalhar os conteúdos, ou não, como você analisava isso?

$\mathrm{P}_{15^{-}}$Nessa parte de pesquisa sobre o plantio e colheita do amendoim, como funcionavam esses maquinários, o consumo deles, combustível, eletricidade.

V- Quer dizer que era possível trabalhar alguns conteúdos?

$\mathrm{P}_{15^{-}}$Era possível, por exemplo, na parte de calor usado na secagem do amendoim.

\footnotetext{
${ }^{56}$ Refere-se ao entrevistador: Valdir Pedro Berti.

${ }^{57}$ Refere-se ao entrevistado: $\mathrm{P}_{16}$.

${ }^{58}$ Cooperativa dos Produtores da Alta Paulista.
} 
V- Mas o conteúdo trabalhado, não se dava de forma linear, é isso?

$\mathrm{P}_{15^{-}}$Ah não, [você trabalhava mecânica, eletricidade e calor ao mesmo tempo, puxando conteúdos das outras séries.] (1)

V- Então, você puxava os conteúdos e isso foi mais atraente para o aluno, ou não, como isso se deu?

$\mathrm{P}_{15}$ - [Atrativo é, porque esse aluno foi até a CAMAP, não deixa de ser atrativo, porque o presidente da CAMAP] (2) foi explicando todo o funcionamento dos maquinários, então é algo que se atrativo para ele.

V- Mas, na hora da abordagem do conteúdo, ele tem mais interesse, ou não?

$\mathrm{P}_{15}$ - Alguma coisa sempre motiva, né? Talvez não motive todos interessados naquele assunto, mas alguma diferença faz.

V- Como ocorria o diálogo com os outros professores, havia esse diálogo, ou não?

$\mathrm{P}_{15}$ - Não, não, [teve encontros para se discutir o projeto, mas eu acho que eram insuficientes, eu acho que se fazer projetos tem que haver mais encontros, mais tempo de discussão.] (3) ocorriam?

V- Mas, dentro da possibilidade que vocês tinham, as HTPCs, como que eles o projeto.

$\mathrm{P}_{15^{-}}$Houve duas dispensas nas últimas aulas para que nós pudéssemos discutir sobre

V- Isso é legal, então, mas como isso ocorria, mesmo assim elas não eram suficientes. Mas, nesses encontros a gente discutia qual era o próximo passo, cada um colocava o que estava sendo feito, e por ser o primeiro projeto, a gente estava meio perdido. $\mathrm{Eu}$ acho que vocês realizaram um bom projeto. Mas, vocês discutiam o quê? Onde o projeto estava e quais os conteúdos iam ser trabalhados, ou não?

$\mathrm{P}_{15^{-}}$[A gente discutia que o projeto está neste momento aqui, às vezes até o professor dava idéia para o outro da disciplina dele, outro eu não sei onde encaixar minha disciplina, o outro tinha uma idéia e falava o isso não dá para você trabalhar? Passava alguma uma sugestão de trabalho.] (4) Por exemplo, inglês perguntava, como eu vou trabalhar minha disciplina no projeto do amendoim, o outro professor sugeria, que tal você trabalhar com a questão da exportação? Porque o nosso amendoim de Herculândia tem um bom mercado de exportação. Um dava uma dica para o outro e era assim.

V- Isso ficava só na questão da metodologia, ou se estendia para conteúdo? 
$\mathrm{P}_{15^{-}}$[Isso era estendido para as disciplinas da gente com a dos outros, havia dicas de sites que os alunos podem pesquisar sobre maquinário é funcionamento, gastos, consumos, funcionamentos etc.] (5)

V- E a questão do seu conteúdos com os demais, você chagam a discutir?

$\mathrm{P}_{15^{-}} \mathrm{Ah}$, sim [os conteúdos repetidos, como gases, por exemplo que é trabalhado na química e na física, a gente falava deixa que dou.] (6) Isso eu acho que faz muita falta esses encontros por área. Isso no projeto acontecia, possibilitava esse momento.

V- Mesmo tendo poucos espaços nas HTPCs a equipe gestora incentiva isso e dava esses espaços?

$\mathrm{P}_{15}$ - Incentiva sim, incentiva.

V- E os alunos relacionavam os conteúdos, ou não?

$\mathrm{P}_{15}$ - De alguns, eu acho que houve até um movimento grande, mas é alguma coisa que não chega a cem cento de envolvimento, para alguns já fica fácil.

V- Esses apáticos são quais alunos?

$\mathrm{P}_{15^{-}}$São aqueles que não querem nada com nada mesmo, os bons tudo que você desenvolver vai.

V- Considerado os alunos desinteressados na aula tradicional, com o projeto não houve nenhuma motivação e aí eu gostaria que você ficasse bem à vontade para responder? Ou seja, a estatística de interessados e desinteressados permaneceu?

$\mathrm{P}_{15}$ - Não, se você está dando determinado assunto e aquele assunto foi desenvolvido no projeto, o interesse aumenta, o mesmo ocorre quando a gente faz à visita a hidrelétrica com os alunos do terceiros anos, então a gente vê que após a visita o assunto tornar-se mais interessante, é a prática, a realidade, se você só passa na lousa, o aluno fala para que isso? Onde eu vou ver isso aí? Rotor, gerador, ele vai lá, ele vê a teoria e a sua aplicação na prática. Então, a gente vê a diferença aí, o aluno entra em contato com a realidade. Tanto é que antes nós deixávamos para fazer a visita na hidrelétrica no final do ano, hoje nós já fazemos no inicio, para explorar melhor o assunto.

$\mathrm{V}$ - Com relação a integração dos professores durante o projeto, você acha que houve, ou não houve?

$\mathrm{P}_{15}$ - Houve sim, [todos estavam num mesmo barco, senão não sairia o projeto.] (7)

V- Então, houve muita integração e com relação a essa integração você classificaria esse projeto como interdisciplinar, multidisciplinar, ou como você viu essa integração? 
$\mathrm{P}_{15^{-}}$[Eu acho que ele foi tudo isso,] (8) mas eu acho que esse tipo de trabalho não deve ser muito longo, porque você começa a deixar os conteúdos para trás, né?

V- É, no projeto você faz uma seleção em alguns conteúdos.

$\mathrm{P}_{15^{-}}$A gente tem os projetos, mas tem os conteúdos para serem desenvolvidos. Senão você acaba deixando os conteúdos para trás.

V- Talvez, trabalhar com projetos menos intensos, com a preocupação de inserir o conteúdo ali. Agora, me diga uma coisa, quando a gente falou dos projetos interdisciplinares desenvolvidos na Diretoria, você já tinha ouvido falar ou foi na Diretoria que você ouviu falar sobre isso?

$\mathrm{P}_{15-}$ Não, foi a partir da Diretoria mesmo.

V- Não foi com estudos nas HTPCs, que você ouviu falar sobre projetos interdisciplinares, não foi isso?

$\mathrm{P}_{15^{-}}$Não tudo começou na Diretoria de Ensino mesmo, e depois o curso em Ilha com as áreas de Química, Física e Biologia, com as orientações da Diretoria.

V-E projetos, vocês tem realizado mais projetos aqui, ou depois daquela época você deram uma parada?

$\mathrm{P}_{15-}$ Não, demos uma parada, porque só projetos não virá.

V- O que você quer dizer com isso?

$\mathrm{P}_{15^{-}} \mathrm{O}$ projeto tem o lado bom e ruim, também.

V- Eu gostaria de ouvir os dois?

$\mathrm{P}_{15^{-}}$lado bom é quem tem a parte de alunos que se envolvem. O lado ruim é que ele demanda muito esforço do professor. E às vezes o professor não está com todo aquele gás para, dado ao número de aula que ele tem, ele não tem tempo disponível para isso. $\mathrm{O}$ professor para trabalhar com projetos ele tem que ser como um professor de faculdade, ele dá quinze ou vinte aulas e ter o tempo restante disponível para fazer o projeto, para ele realmente funcionar realmente.

V- Talvez, a escola de tempo integral propicie isso que você está falando, pois ela tem dois currículos (currículo básico e oficinas curriculares), em que se possa desenvolver projetos dessa natureza.

$\mathrm{P}_{15^{-}}$Nesse caso sim, de outra forma eu acho que não é viável, porque tem professor que tem dois cargos, cinquienta e três aulas, como esse professor irá ter tempo para desenvolver um projeto? Então ele vem e dá o conteúdo dele normal. Se ele tentar dar esse número de aula e fazer projeto, ele não agüenta não. Porque fazer projeto é muito cansativo. 
O professor tem que dar menos aulas e ter mais tempo para pesquisar e correr atrás das coisas.

$\mathrm{V}$ - Ou seja, condições de trabalho. Bom, $\mathrm{P}_{15}$ estou satisfeito com o nosso bate-papo e gostaria de agradecê-lo pela disponibilidade. 
Entrevista: $\mathrm{P}_{16}$

Data: 07/05/05

Tempo Total: $32 \mathrm{~min}$.

$\mathrm{V}^{59}$ - Em 2003, o supervisor implantou na Diretoria de Ensino à proposta de trabalhos com projetos. Qual era a expectativa?

$\mathrm{P}_{16}{ }^{60}$ - A expectativa e de uma mudança total na maneira de desenvolver o conteúdo e também por consequiência [a obtenção de competência,] (1) isso daí engloba um monte de coisa, um monte de mudanças, no [currículo no foco do ensino que era conteudista e de repente deixa de ser em si mesmo para ser um meio para que atingir competência,] (2) a maneira de desenvolver esse conteúdo, também é feita através de conteúdos essenciais e mexendo também com a maneira do aluno trabalhar, [ele passa a ser sujeito da ação saindo da passividade que predominava dentro das aulas expositivas], (3) ele então [passando a ser protagonista,] (4) obrigatoriamente vai encontrar significados para aquilo que a gente está teoricamente passando para ele e através [da prática ele vai então resolver a situaçõesproblema ] (5) através da aplicação desse conteúdo que naturalmente deu a ele a possibilidade de adquirir competência, então ele vai praticar através de exercícios que o professor vai propiciar a ele, ele vai praticar a contextualização.

$\mathrm{V}-\mathrm{P}_{16}$. Esse tipo de trabalho traz uma forma de trabalhar com currículo integrado? Ou seja, de trabalhos interdisciplinares e transdisciplinares; é mais ou menos isso?

$\mathrm{P}_{16^{-}}$[É através da interdisciplinaridade que vai se trabalhar o projeto com o fim principal da não a fragmentação do conhecimento], (6) só que tem que deixar bem claro o seguinte[é preciso que haja uma disciplinaridade bem dominada para poder haver a interdisciplinaridade] (7) e depois por consequiência a transdisciplinaridade, eu acho que o professor realmente vai ter condições de trabalhar [esse relacionamento de disciplinas de uma forma que se torne mais atraente para o aluno] (8) e que também haja uma praticisação do conteúdo através então de um projeto e só através deu um [projeto nós vamos ter uma flexibilização] (9) podendo inserir com novos conteúdos ou suprimir outros ou ainda redirecionar o próprio projeto através então da realização ou da obediência a um cronograma para que realmente haja a avaliação constante e com novas possibilidades se assim for necessário.

V- Na sua visão os professores têm conseguido trabalhar com essa nova proposta; efetivamente na prática eles conseguem fazer esse tipo de trabalho?

$\mathrm{P}_{16}$ - Aí há uma série de interferências, a primeira grande interferência é que eles são formados de uma maneira e de repente a gente está querendo trabalhar deu uma outra maneira, mas há essa resistência porque para a grande maioria a formação continuada é uma balela, ainda não acontece, então eles não têm o hábito do estudo e para isso ele vai

\footnotetext{
${ }^{59}$ Entrevistador: Valdir Pedro Berti.

${ }^{60}$ Entrevistado: $\mathrm{P}_{16}$.
} 
precisar logicamente se apetrechar, precisa botar a mão na massa como se diz e estudar, tem que estudar para depois tomar as atitudes necessárias.

\section{V- Parece-me que então depende um pouco de políticas públicas?}

$\mathrm{P}_{16}$ - Não tem nem dúvida, a implicância do trabalho com projeto é muito grande não só nos ângulos que falei, mas também em cima da avaliação que tem que ser feita de uma maneira diferente e que é aproveitada, ou melhor, aproveitável em nível de aluno em nível de professor em nível de escola em nível de comunidade e em nível de governo para saber se aquilo que eles estão fazendo realmente está de acordo ou se há necessidade da adoção de novas medidas. Lógico que [nesse caso a que se mexer na legislação] (10) [sobre escola, principalmente quanto ao número de horas atividades, pois o professor tem que ter um maior número de horas atividades], (11) assim como era na escola-padrão propiciando o encontro com os colegas porque senão não vai haver o trabalho coletivo que também é uma das condições sine qua non desse trabalho, porque o individualismo ele tem que existir enquanto a pessoa busca conhecimento, busca se aprimorar, mas em realidade o que tem que acontecer é juntar-se a outros colegas para poder haver o crescimento e o entrosamento do trabalho, então começa por aí, tem que haver uma mudança no número de horas de atividades tem que haver uma mudança no número de aluno dentro de uma sala de aula por que o professor para trabalhar realmente não essa concepção ele precisa sempre quis dar de posse de um diagnóstico desse aluno para saber por onde ele vai começar a mediação do conhecimento que fazendo mediação ele vai então fazer com que não exista defasagem para ou aluno ele vai então também enseja a possibilidade da progressão continuada que é o caminho que é o caminho que no meu entender não tem retorno ou é, ou tem que ser.

\section{V- Como que as universidades poderiam ajudar neste processo?}

$\mathrm{P}_{16^{-}}$Não tem nem dúvida que ela tem o quinhão dela a ser dado, mas ela tem que ser modificada, ela tem o ensino superior tem que se modificar especificamente nesse caso na parte pedagógica nas diversas disciplinas têm que mudar desenvolvimento no próprio professor essa autonomia que se faz necessária que se prega hoje em dia para que o aluno que se desenvolve no aluno precisa ver se o professor tem que se ele consegue trabalhar dessa forma, então começa por aí e na capacitação de como o ensejar quais conteúdos a trabalhar para que o aluno adquira a sua identidade individual e a sua identidade coletiva.

V- Quais foram às conquistas desse trabalho ao longo de dois anos?

$\mathrm{P}_{16--}$ Em primeiro lugar talvez o mais importante seja a sedução do aluno através de desafios se conseguiu trazer o aluno de novo para a sala de aula, ele deu uma maneira bem com um percentual bem grande ele a domina, ele passa de novo a acreditar na escola. Acho que ainda é um trabalho incipiente, mas a gente nota através dos depoimentos dos professores e através dos depoimentos dos alunos que ele passou a se interessar mais pela aula e pelo conteúdo dando aulas em desse conteúdo ele aprendeu também que ele tem que adquirir competência para poder enfrentar todo um conhecimento que é despejado no mundo diariamente. 
V- Ao que me parece neste tipo de trabalho à relação aluno e aluno melhora e a relação aluno e professor?

$\mathrm{P}_{16^{-}} \mathrm{O}$ professor e o aluno passam a se tornar cúmplices e ao se tornarem cúmplices do conhecimento eles serão cúmplices em uma relação em que o professor passa ao ocupar novamente posição de referencial para o aluno. residência.

$\mathrm{V}$ : $\mathrm{P}_{16}$, obrigado pela entrevista e pela disponibilidade de me receber na sua

$\mathrm{P}_{16}$ : As ordens é sempre um prazer! 